\title{
DESVELANDO A IDENTIDADE DA PÓS-GRADUAÇÃO EM SAÚDE PÚBLICA
}

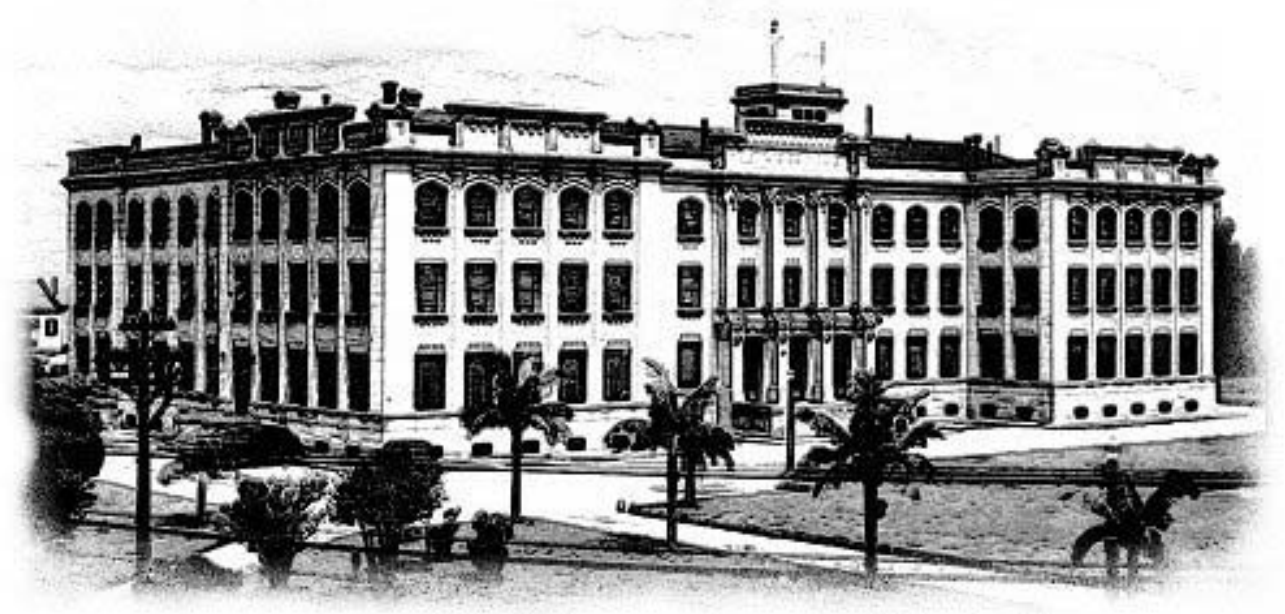

Cleide Lavieri Martins

Tese de Doutorado apresentada à Faculdade de Saúde Pública da Universidade de São Paulo como requisito parcial para obtenção do Grau de Doutor em Saúde Pública - Área de Concentração: Serviços de Saúde Pública.

Orientador: Prof. Fernando Lefèvre

São Paulo

1999 
Dedicatória

Dedico não só este trabalho, mas a minha história profissional, ao meu pai ex-aluno desta Casa e sanitarista otimista.

Seu sorriso, seu carinho, sua torcida e seu olhar orgulhoso fazem muita falta. 


\section{Agradecimentos}

À Profa Nilce Piva Adami - orientadora próxima do orientando que me orientou no mestrado e iniciou minha orientação no doutorado.

Ao Prof Fernando Lefèvre - que me aceitou no meio do caminho um orientador que confia no seu orientando.

Às Professoras Rita Barradas Barata, Miriam Krasilchik, Ana Cristina D'Andretta Tanaka ao Prof Arnaldo Augusto Franco de Siqueira, professores que participaram da pré banca, pela atenciosa e valiosa contribuição. Em especial ao Prof Arnaldo que muito além das vírgulas e crases me deu o apoio necessário e na hora certa.

À Profa Ana Maria Saul e Isabel Bicudo pela contribuições trazidas no exame de qualificação - iluminando o caminho da pesquisa.

Às meninas da Assessoria Acadêmica da FSP - Angela, Marilena, Silvia e Renilda - pelas idas ao arquivo morto, e pela disposição em dar informações e procurar documentos.

Aos professores e alunos - "meu sujeitos" - pelo interesse, boa vontade e seriedade com que deram seus depoimentos.

Às pessoas que torceram por mim e entraram em pânico com as minhas longas paradas.

Às amigas que foram muito presentes e prontas a ajudar de diferentes formas - Lavínia, Cidinha, e Cristina Sanna.

A Profa Maria da Penha, persistente e amiga, que me acompanhou desde muito antes da escolha do tema e com quem eu aprendi muito.

A minha família pela certeza do acolhimento com amor, em especial ao Marco que eu tenho a impressão decorou os dados deste trabalho, ao Beto pela capa, a Hanny pelo inglês, às crianças grandes pelas consultas à Internet e a ajuda com o computador, às crianças pequenas pela alegria, a etc etc etc ... 


\section{RESUMO}

Martins CL. Desvelando a identidade da pós-graduação em saúde pública. São Paulo; 1999. [ Tese de Doutorado - Faculdade de Saúde Pública da USP].

O propósito desta pesquisa foi o de contribuir para a discussão de questões que dizem respeito às peculiaridades do ensino em saúde pública do Programa de Pós-Graduação Stricto Sensu da Faculdade de Saúde Pública da Universidade de São Paulo (FSP). Trata-se de um estudo de caso, cujo caminho metodológico buscou compreender o processo de formação mediante as representações daqueles que nele atuam. Foram colhidos depoimentos de dez alunos e oito professores e analisados documentos referentes ao desenvolvimento dos cursos de mestrado e doutorado na FSP entre 1990 e 1997. A partir do estudo foi possível constatar que a pós-graduação da FSP não vem respondendo às mudanças ocorridas no quadro social sanitário do país, e às recentes transformações no ensino superior, ressentindo-se de um projeto próprio que responda às novas necessidade de formação de profissionais nesse campo.

Descritores: Saúde Pública. Pós-Graduação. Avaliação. 


\section{SUMMARY}

Martins CL. Desvelando a identidade da pós-graduação em saúde pública. [Disclosing the identidy of the post graduation program in public health] São Paulo (BR), 1999. [Tese de Doutorado - Faculdade de Saúde Pública da Universidade de São Paulo].

The purpose of this research was to contribute to the discussion of subjects regarding to the peculiarities of the teaching in the public health of the Post Graduation Stricto Sensu Program of the Faculdade de Saúde Pública of the Universidade de São Paulo (FSP). It is a case study whose methodology is an attempt to understand the educacional process according to the representation by those who are directly involved in this program. Statements from ten students and eight teachers have been gathered and documents related to the development of the master's degree courses have been analysed, so as to the doctor's degree courses, in the FSP, between 1990 and 1997. In carrying out this study it was possible to identify the Post Graduation Program of the FSP has not been providing any guidance that should corresponding the recent changes occured in the social and sanitary sector as well as in the university teaching in the country, revealing a lack of a personal educational development that provides the real requiriments in preparing professionals in this area.

Descriptors: Public Health. Post Graduation. Evaluation. 


\section{ÍNDICE}

Página

Relação de Siglas

Relação de quadros, tabelas e gráficos. iv

$\begin{array}{ll}\text { Apresentação } & 1\end{array}$

Capítulo I: Circunscrevendo a questão 3

1. Origens da formação em saúde pública no Brasil 3

2. Quadro atual da pós-graduação stricto sensu em saúde pública no 8 Brasil

3. A Faculdade de Saúde Pública: atividades de extensão 20 universitária, pesquisa e ensino,

4. O processo de construção da pesquisa. 35

4.1. Objetivos 35

4.2. Procedimentos metodológicos $\quad 35$

Capítulo II: Caracterizando o corpo discente e docente 46

1. Corpo discente 48

2. Corpo docente 56

Capítulo III: Sujeitos, processos, e representações

1. Afinal, quem faz no cotidiano da Faculdade a pós-graduação? 68

2. Como se faz no cotidiano da Faculdade a pós-graduação? 98

3. No cotidiano da pós-graduação um "salve-se quem puder" 161

$\begin{array}{ll}\text { Capítulo IV: Considerações finais } & 170\end{array}$

$\begin{array}{ll}\text { Referências Bibliográficas } & 175\end{array}$

Anexos 


\section{RELAÇÃO DE SIGLAS}

\begin{tabular}{|c|c|}
\hline ABRASCO & Associação Brasileira de Pós-Graduação em Saúde Coletiva \\
\hline $\mathrm{AH}$ & Administração Hospitalar \\
\hline ANPEd & Associação Nacional de Pós-Graduação e de Pesquisa em Educação \\
\hline CAPES & Fundação Coordenação de Aperfeiçoamento de Pessoal de Nível Superior \\
\hline CCEX & Comissão de Cultura e Extensão Universitária \\
\hline CCS & Centro de Ciências da Saúde \\
\hline CETESB & Companhia de Tecnologia de Saneamento Ambiental \\
\hline CFE & Conselho Federal de Educação \\
\hline COSEMS & Conselho de Secretários Municipais de Saúde \\
\hline CPG & Comissão de Pós-Graduação \\
\hline DNSP & Departamento Nacional de Saúde Pública \\
\hline ECA & Escola de Comunicações e Artes \\
\hline EESC/USP & Escola de Engenharia de São Carlos/USP \\
\hline ENSP & Escola Nacional de Saúde Pública \\
\hline EP & Escola Politécnica \\
\hline EPI & Epidemiologia \\
\hline FAU & Faculdade de Arquitetura e Urbanismo \\
\hline FCAV & Faculdade de Ciências Agrárias e Veterinária \\
\hline FCF & Faculdade de Ciências Farmacêuticas \\
\hline FCM & Faculdade de Ciências Médicas \\
\hline FEA & Faculdade de Economia e Administração/USP \\
\hline FFLCH & Faculdade de Filosofia, Letras e Ciências Humanas \\
\hline FGV & Fundação Getúlio Vargas \\
\hline FIOCRUZ & Fundação Oswaldo Cruz \\
\hline FM & Faculdade de Medicina \\
\hline FMVZ & Faculdade de Medicina Veterinária e Zootecnia \\
\hline FO & Faculdade de Odontologia \\
\hline FSP & Faculdade de Saúde Pública \\
\hline FUFMS & Fundação Universidade Federal Mato Grosso do Sul \\
\hline FUNDACENTRO & Fundação Jorge Duprat Figueiredo Segurança e Medicina do Trabalho \\
\hline HCFMUSP & Hospital das Clínicas da Faculdade de Medicina da USP \\
\hline HEP & Departamento de Epidemiologia/FSP/USP \\
\hline HNT & Departamento de Nutrição/FSP/USP \\
\hline HSA & Departamento de Saúde Ambiental/FSP/USP \\
\hline HSM & Departamento de Saúde Materno Infantil/FSP/USP \\
\hline
\end{tabular}




$\begin{array}{ll}\text { HSP } & \text { Departamento de Prática de Saúde Pública/FSP/USP } \\ \text { IAMSP } & \text { Instituto de Assistência Médica ao Servidor Público Estadual "Francisco } \\ & \text { Morato de Oliveira" } \\ \text { IB } & \text { Instituto de Biologia } \\ \text { ICB } & \text { Instituto de Ciências Biomédicas } \\ \text { IMIP } & \text { Instituto Materno Infantil de Pernambuco } \\ \text { IMS } & \text { Instituto de Medicina Social } \\ \text { IP } & \text { Instituto de Psicologia } \\ \text { IPEN } & \text { Instituto de Pesquisas Energéticas e Nucleares } \\ \text { IQ } & \text { Instituto de Química } \\ \text { LDB } & \text { Lei de Diretrizes e Bases da Educação Nacional } \\ \text { MEC } & \text { Ministério da Educação e do Desporto } \\ \text { MS } & \text { Ministério da Saúde } \\ \text { NESC } & \text { Núcleo de Estudos em Saúde Coletiva } \\ \text { NUT } & \text { Nutrição } \\ \text { OSEC } & \text { Organização Santo Amarense de Educação e Cultura } \\ \text { PEPG } & \text { Programa de Estudos de Pós-Graduados } \\ \text { PROLAM } & \text { Programa de Pós-Graduação em Integração da América Latina/USP } \\ \text { PUC } & \text { Pontifícia Universidade Católica de São Paulo } \\ \text { PUCCAMP } & \text { Pontifícia Universidade Católica de Campinas } \\ \text { SA } & \text { Saúde Ambiental } \\ \text { SESSP } & \text { Secretaria de Estado da Saúde de São Paulo } \\ \text { SMI } & \text { Saúde Materno Infantil } \\ \text { SPG } & \text { Seção de Pós-Graduação } \\ \text { SSP } & \text { Serviços de Saúde Pública } \\ \text { SUS } & \text { Sistema Único se Saúde } \\ \text { UECE } & \text { Universidade do Estado do Ceará } \\ \text { UEL } & \text { Universidade Estadual de Londrina } \\ \text { UEM } & \text { Universidade Estadual de Maringá } \\ \text { UERJ } & \text { Universidade Estadual do Rio de Janeiro } \\ \text { UFAL } & \text { Universidade Federal de Alagoas } \\ \text { UFBA } & \text { Universidade Federal da Bahia } \\ \text { UFC } & \text { Universidade Federal do Ceará } \\ \text { UFF } & \text { Universidade Federal Fluminense } \\ \text { UFGO } & \text { Univeral de Mato Grosso } \\ \text { UFMG } & \text { UFMT }\end{array}$




$\begin{array}{ll}\text { UFPE } & \text { Universidade Federal de Pernambuco } \\ \text { UFPEL } & \text { Universidade Federal de Pelotas } \\ \text { UFPR } & \text { Universidade Federal do Paraná } \\ \text { UFRJ } & \text { Universidade Federal do Rio de Janeiro } \\ \text { UFRS } & \text { Universidade Federal do Rio Grande do Sul } \\ \text { UFSC } & \text { Universidade Federal de Santa Catarina } \\ \text { UFSCAR } & \text { Universidade Federal de São Carlos } \\ \text { UnB } & \text { Universidade de Brasília } \\ \text { UNESP } & \text { Universidade Estadual de São Paulo } \\ \text { UNICAMP } & \text { Universidade Estadual de Campinas } \\ \text { UNIFESP } & \text { Universidade Federal de São Paulo } \\ \text { USP } & \text { Universidade de São Paulo }\end{array}$




\section{RELAÇÃO DE QUADROS, TABELAS E GRÁFICOS}

Gráfico 1 - Alunos de Mestrado e Doutorado/FSP, segundo curso 1973 a 1995.

$\operatorname{pg} 48$

Gráfico 2 - $\quad$ Alunos de Mestrado/FSP segundo área de concentração, 1973-1995.

pg 50

Gráfico 3 - Alunos de Doutorado/FSP segundo área de concentração, 19731995.

$\operatorname{pg} 50$

Gráfico 4 - $\quad$ Alunos de Mestrado/Doutorado/FSP segundo sexo, 1973-1995.pg 51

Gráfico 5- Alunos de Mestrado e Doutorado/FSP, segundo sexo e área de concentração, 1973 a 1995.

pg 52

Gráfico 6 - Alunos de Mestrado e Doutorado/FSP, segundo idade média e ano de ingresso, 1973 a 1995.

pg 53

Gráfico 7 - Pós-Graduação Stricto Sensu FSP/USP - Orientadores segundo sexo, 1996.

pg 63

Gráfico 8 - Pós-Graduação Stricto Sensu FSP/USP - Orientadores segundo faixa etária, 1996.

pg 64

Gráfico 9 - Pós-Graduação Stricto Sensu FSP/USP - Orientadores com vínculo empregatício na FSP/USP, segundo regime de trabalho e área de concentração, 1996.

pg 65

Gráfico 10 - Pós-Graduação Stricto Sensu FSP/USP - Disciplinas oferecidas e não oferecidas segundo ano, 1990 a 1997.

pg 125

Gráfico 11 - Pós-Graduação Stricto Sensu FSP/USP - Disciplinas do Departamento de Prática de Saúde Pública/FSP/USP segundo área de concentração e ano, 1990 a 1996.

pg 126 
Quadro 1 - Cursos de Pós-Graduação Stricto Sensu em Saúde Coletiva. Brasil, 1997. pg 16

Quadro 2 - Caracterização dos alunos entrevistados, 1997.

$\operatorname{pg} 38$

Quadro 3 - Pós-Graduação Stricto Sensu FSP/USP - Disciplinas Obrigatórias para o Mestrado segundo no de créditos e ano, 1990 a 1998. pg 109

Quadro 4- Disciplinas de Pós-Graduação Stricto Sensu do Departamento de Prática de Saúde Pública/FSP/USP segundo nํ de alunos, 1990 a 1997.

$\operatorname{pg} 125^{\mathrm{a}}$

Tabela 1 - Candidatos à Pós-Graduação Stricto Sensu FSP/USP, segundo nível do curso e fase do processo seletivo, 1994 a 1998.

$\operatorname{pg} 49$

Tabela 2 - Candidatos ao Mestrado e Doutorado FSP/USP, Segundo formação na graduação, 1996 e 1997.

pg 54

Tabela 3 - $\quad$ Alunos de Mestrado FSP/USP segundo vínculo empregatício, 1992 a 1995.

$\operatorname{pg} 55$

Tabela 4 - $\quad$ Alunos de Doutorado FSP/USP segundo vínculo empregatício, 1992 a 1995.

$\operatorname{pg} 55$

Tabela 5 - Curso de Pós-Graduação Stricto Sensu FSP/USP - Orientadores segundo área de concentração e vínculo com a FSP, 1996. pg 57

Tabela 6 - Pós-Graduação Stricto Sensu FSP/USP - Orientadores segundo formação na graduação, $1996 . \quad$ pg 58

Tabela 7 - Pós-Graduação Stricto Sensu FSP/USP - Orientadores segundo local de doutoramento, $1996 . \quad$ pg 61 
Tabela 8 - Pós-Graduação 'Stricto Sensu” FSP/USP - Orientadores segundo tempo de credenciamento e vínculo com a FSP, $1996 . \quad$ pg 62

Tabela 9 - Pós-Graduação Stricto Sensu FSP/USP - Membros das Comissões Julgadoras de exames de qualificação e defesas segundo área de concentração, 1990 a $1996 . \quad$ pg 108

Tabela 10 - Pós-Graduação Stricto Sensu FSP/USP - Disciplinas eletivas segundo departamento e oferecimento ou não da disciplina, 1990 a 1997.

pg 124 


\section{APRESENTAÇÃO}

A motivação para o estudo dos cursos de pós-graduação stricto sensu da Faculdade de Saúde Pública da Universidade de São Paulo (FSP) está intimamente associada à minha trajetória profissional na área de saúde pública como enfermeira de serviços de saúde e como professora da FSP que possibilitaram meu envolvimento com questões relativas ao ensino em saúde pública.

Minha trajetória em muitos pontos é semelhante às trazidas pelos sujeitos deste estudo - fui fazer curso de Graduação em Enfermagem "já" para ser enfermeira de saúde pública. Após atuar em centros de saúde na Secretaria de Estado da Saúde e fazer o Curso de Especialização em Saúde Pública na FSP, fui comissionada para ensinar "o fazer" enfermagem para alunas recém graduadas. Os dilemas advindos desses diferentes papéis me levaram a buscar a compreensão do espaço em que atuo.

Do ponto de vista da reflexão sistemática esta pesquisa é um desdobramento do estudo sobre o perfil do aluno de pós-graduação da FSP do período de 1973 a 1995 (MARTINS e VASCONCELLOS,1996), que visava levantar questões que subsidiassem o planejamento educacional na FSP. A continuidade no estudo do tema é conseqüência do conjunto de questões suscitadas pela análise dos dados desse levantamento, pelo momento de revisão por que vem passando a Faculdade, e pelas novas propostas surgidas na política de pós-graduação do país.

A partir da análise de documentos, de depoimentos de alunos e professores da FSP, o propósito do trabalho foi o de contribuir para a interpretação de questões que dizem respeito às peculiaridades do ensino ministrado pela FSP, por meio dos cursos de mestrado e doutorado, e influir na direção de um repensar do processo educativo em saúde pública.

No capítulo I abordamos a questão da pós-graduação em saúde pública no Brasil e apresentamos a FSP em suas atividades de ensino, pesquisa e extensão 
universitária circunscrevendo, assim, a questão fundamental da pesquisa. Descrevemos ainda o processo de construção da pesquisa.

Com o objetivo de situar o leitor na pós-graduação da FSP, no Capítulo II identificamos o perfil do corpo docente e discente, tendo como base documentos da Faculdade e trabalhos de pesquisa sobre o tema.

No Capítulo III elaboramos uma reflexão sobre o cotidiano dos cursos a partir do depoimento daqueles que nele atuam - alunos e professores, identificando quem é o aluno e o professor da FSP, quais suas aspirações, e como eles vivenciam a Pós-Graduação.

Terminamos este trabalho fazendo no Capítulo IV algumas considerações finais. 


\section{Capítulo I- CIRCUNSCREVENDO A QUESTÃO}

\section{ORIGENS DA FORMAÇÃO EM SAÚDE PÚBLICA NO BRASIL}

Em nosso país, a formação de pessoal de nível superior em saúde pública ocorre, formalmente, em cursos de pós-graduação lato sensu e/ou stricto sensu. Os cursos nessa área se caracterizam por qualificar profissionais com diferentes formações básicas na graduação, procedentes tanto das áreas de ciências da saúde, como humanas, biológicas, e exatas. Os cursos de especialização lato sensu têm como objetivo capacitar profissionais para atuação técnica e administrativa no campo da saúde pública. O mestrado e doutorado stricto sensu - visam a qualificação de pessoal de alto nível na saúde pública, o preparo para o magistério superior, e para a pesquisa (USP, 1994).

A origem desses cursos, ou melhor, da institucionalização da formação sanitária no Brasil ocorreu, segundo LABRA, no início do século, no interior do movimento nacionalista, nas décadas de 1910 e 1920. O primeiro curso de Higiene e Saúde Pública, destinado a formar médicos sanitaristas no país, surgiu no bojo da reforma sanitária promovida pelo Governo Federal em 1920-1923 e complementarmente com a reforma do ensino de 1925 (LABRA, 1985).

O movimento sanitarista ocorreu com forte influência da Fundação Rockefeller ${ }^{1}$ tanto no Rio de Janeiro como em São Paulo, se conformando às características de cada estado.

Ao estender seu modelo, a Fundação influenciou uma nova concepção e atuação na área da saúde pública que priorizava a educação popular, o combate às verminoses e às endemias locais e os inquéritos de natureza social para verificação

\footnotetext{
${ }^{1}$ A Comissão Sanitária Rockefeller foi criada em 1901, com o objetivo de erradicar a ancilostomíase e a malária no sul dos Estados Unidos. A iniciativa do Grupo Rockefeller atendia aos interesses econômicos dos capitalistas nortistas de integrar o sul atrasado e lá constituir novos mercados e um reservatório de mão de obra. Em 1913 foi criada a Fundação Rockefeller passando a ter como objetivo a internacionalização em ampla escala de suas ações, momento que passa a reforçar suas atividades junto à saúde pública, a pesquisa e à educação médica, especialmente através do repasse de tecnologia e recursos financeiros via convênios bilaterais com diversos governos. Nos anos seguintes após sua criação voltou suas atenções para a América Latina.(RIBEIRO,1993 e PALMA, 1996)
} 
do padrão de vida e higiene da população (VASCONCELLOS, 1995).

No Rio de Janeiro, em momento posterior a São Paulo, a "modernização dos serviços de saúde pública propiciada pela Reforma Sanitária de 1920 teria lançado as bases para um modelo institucional urbano consoante com a intenção de seu promotor, o Dr. Carlos Chagas, de articular as ações do Instituto Oswaldo Cruz e do Departamento Nacional de Saúde Pública - DNSP (dos quais Chagas era conjuntamente diretor), para influenciar na solução dos grandes problemas de desenvolvimento nacional e a elevação do padrão de saúde do povo" (LABRA, 1985).

O surgimento desse Departamento teria sido um "esforço notavelmente bem sucedido de trazer para o interior do aparelho estatal toda uma geração de jovens sanitaristas até então situados mais ou menos à margem do processo decisório relativo à questão sanitária, o que significou por um lado, a aproximação daqueles com as elites políticas e, por outro, facilitou a sua consolidação como grupo de intelectuais, passando a configurar, enfim, um movimento ideológico hoje lembrado como o movimento sanitarista" (LABRA, 1985).

Em São Paulo, no momento histórico em que a sociedade paulista deparava-se com um acelerado crescimento urbano-industrial, com a agudização de conflitos sociais e com setores dominantes desta sociedade expressando desejos de construir uma nova ordem nacional e um novo perfil de trabalhador, são criadas instituições com caráter e finalidades diversas, com o objetivo de, cada qual na sua área, estudar, conhecer, identificar e propor soluções para as "questões urbanas". Foram criados, por exemplo: o Departamento Estadual do Trabalho (1911), a Repartição de Estatística e Arquivo (reorganizada em 1911), a Faculdade de Medicina e Cirurgia (1913), o Instituto de Engenharia (1917), para discutir, propagar e implementar novas concepções sobre higiene, saúde, trabalho e educação, com base em dispositivos técnico-racionalizadores e que tiveram ampla penetração na sociedade paulista (VASCONCELLOS, 1995).

O agravamento das condições sanitárias, nas zonas rurais com 0 aparecimento da malária epidêmica, levou o governo do Estado de São Paulo a iniciar conversações com a Fundação Rockeffeler para que esta instituição 
colaborasse no combate à malária. A Fundação já estava atuando no Brasil em convênios com os estados do Rio de Janeiro e de Minas Gerais. A diferença da atuação da Rockefeller em São Paulo em relação à atuação dessa instituição em outros estados resultava do fato de São Paulo contar com um serviço sanitário e com uma estrutura de saúde pública. A Fundação e o Serviço Sanitário desenvolveram seus trabalhos de profilaxia da malária e da ancilostomíase independentemente em zonas diferentes do Estado. Em São Paulo a Fundação Rockefeller teve também papel importante no ensino médico (RIBEIRO, 1993).

Nesse contexto encontramos as origens da Faculdade de Saúde Pública da Universidade de São Paulo (FSP) quando, em 1918, a Fundação Rockefeller instala na recém criada Faculdade de Medicina e Cirurgia de São Paulo, junto à Cadeira de Higiene o Laboratório de Higiene, montado em anexo à Faculdade. Constituía-se, em São Paulo, a primeira instituição dedicada ao ensino da higiene e saúde pública, idealizada e mantida por convênio direto com essa Fundação, apenas um ano após a criação da escola de Higiene e Saúde Pública na Universidade de Johns Hopkins, em Baltimore (CANDEIAS, 1984 e VASCONCELLOS, 1995).

De acordo com VASCONCELLOS (1995) os princípios norteadores das origens da FSP "seguiram a orientação geral da Fundação Rockefeller para a implementação de escolas de saúde pública no mundo inteiro, estabelecendo como meta o ensino dos aspectos 'científicos' da higiene aliado à 'tarefa prática' de preparar os técnicos necessários ao provimento de cargos de saúde pública ou, em outras palavras, 'ao apostolado da higiene'. A Fundação reforçava, também, o espírito de investigação e o caráter interdisciplinar da formação e da atuação do profissional dedicado à 'Ciência' e à 'Arte' da higiene."

Já nessa época, o Laboratório de Higiene era denominado de Instituto de Higiene. Sob a direção de Paula Souza, em 1924, o Instituto foi oficializado e ganhou autonomia em relação à Faculdade de Medicina. Com a autonomia, o Instituto de Higiene recebeu outras atribuições além de auxiliar a Cadeira de Higiene: a de realizar cursos de aperfeiçoamento técnico para funcionários do Serviço Sanitário (PALMA, 1996). 
Segundo (RIBEIRO, 1993) "Quando da oficialização do Instituto de Higiene, a crítica mais severa à autonomia era de que o órgão se propunha a ser uma nova direção do Serviço Sanitário do Estado e que com sua oficialização, multiplicava-se o seu poder. De fato, as atribuições dadas ao Instituto absorviam funções do Instituto Bacteriológico, do Instituto Vacinogênico, do Instituto Butantã e da própria Diretoria do Serviço Sanitário, tais como estudar planos e métodos de campanha sanitária, emitir parecer sobre assuntos de higiene e organizar comissões especiais para o estudo de higiene".

"Durante a gestão Paula Souza (1922-1927), coube ao Instituto de Higiene a formulação da política de saúde. Nas suas aulas, no antigo prédio alugado à rua Brigadeiro Tobias, os Drs. Paula Souza e Borges Vieira elaboraram a reforma do Serviço Sanitário do Estado. O papel de órgão pensante do Instituto de Higiene durou enquanto Paula Souza acumulou os cargos de diretor do Serviço Sanitário e diretor do Instituto de Higiene, mesmo porque o Instituto não fazia parte da estrutura do Serviço Sanitário, pois era um órgão independente, ou melhor subordinado diretamente ao secretário do Interior, assim como o era a Escola Politécnica e a Faculdade de Medicina e Cirurgia de São Paulo" (RIBEIRO, 1993).

Se o papel do Instituto de Higiene de órgão pensante e formulador das diretrizes da saúde pública foi efêmero, o mesmo não se pode dizer do papel que the reservou a Reforma Paula Souza, o de formador dos novos agentes do serviço sanitário - educadoras sanitárias e, mais tarde, médicos sanitaristas (RIBEIRO, 1993).

Um ano após a autonomia do Instituto, criou-se o curso de Educadores Sanitários, cujo objetivo era dotar as jovens formandas da escola normal de conhecimentos de higiene, de forma que elas pudessem atuar junto aos Centros de Saúde. Os centros de saúde eram o eixo da organização sanitária proposta por Paula Souza. Mais tarde, foram instalados os cursos de Higiene e Saúde Pública para médicos seguindo o modelo do curso de Higiene da universidade norteamericana Johns Hopkins Medical School (RIBEIRO, 1993; USP, 1994 e VASCONCELLOS, 1995).

A partir de 1925 passariam a ser exigidos, ao menos formalmente, cursos 
técnicos de especialização como pré-requisito para o provimento de alguns cargos no Serviço Sanitário, o que ocorreria junto a uma discussão mais ampla sobre a modernização das estruturas administrativas, cargos e carreiras. Em São Paulo, só poderiam exercer o cargo de Educador Sanitário os alunos diplomados pelo Instituto de Higiene, que passavam a ter prioridade para ingresso no serviço público (PALMA, 1996).

Foi então, ainda como Instituto de Higiene de São Paulo, que a FSP teve lançadas as bases para o início de sua pós-graduação lato sensu, como conhecemos hoje, a partir da criação do Curso de Especialização em Higiene e Saúde Pública para Médicos.

Influenciada por outros organismos internacionais como a Organização Panamericana da Saúde e a Fundação Kellogg, que também tiveram forte orientação sobre as políticas públicas de saúde do Brasil, a FSP foi aos poucos ampliando o número de cursos oferecidos - Saúde Pública para Engenheiros - 1949, Veterinários - 1957, Dentistas - 1958, Enfermeiros - 1959; e Especialização em Organização e Administração Hospitalar -1951 (VASCONCELLOS, 1995).

No âmbito da USP2, pela Portaria do Reitor GR no 120/63, esses cursos passaram, em 1963, a ser chamados de cursos de pós-graduação (USP, 1994), sendo considerados os cursos que conferiam o título de sanitarista aos diferentes profissionais que o procuravam; emblemáticos na formação do sanitarista, foram de grande significado no cenário nacional. Passaram também por esse curso muitos profissionais da América Latina e da África Portuguesa.

Destacamos que como indicado por VASCONCELLOS (1995) "desde o seu início, o ensino foi o propósito fundamental da FSP, funcionando como um treinamento intensivo para a preparação de técnicos para os serviços de saúde pública". Podemos observar ainda, a intensa relação entre esse papel de "treinador" e o de elaborador das políticas públicas de saúde para o estado.

2 Em 1938, o Instituto de Higiene foi incorporado à Universidade de São Paulo. 


\section{QUADRO ATUAL DA PÓS-GRADUAÇÃO STRICTO SENSU EM SAÚDE PÚBLICA NO BRASIL}

Após a Reforma Universitária e a Lei de Diretrizes e Bases de 1968 foi criada no Brasil a pós-graduação stricto sensu entendida como: "o ciclo de cursos regulares em seguimento à graduação, sistematicamente organizados, visando a desenvolver e a aprofundar a formação adquirida no âmbito da graduação e conduzindo à obtenção de grau acadêmico (...). É de natureza acadêmica e de pesquisa e mesmo atuando em setores profissionais tem objetivo essencialmente científico, enquanto a especialização, via de regra, tem sentido eminentemente prático profissional" (CARVALHO, 1975). A pós-graduação lato sensu passou, então, a designar todo e qualquer curso que se segue à graduação como os de aperfeiçoamento e especialização que conferem certificados de eficiência e aproveitamento conforme o Parecer 977/65 do Conselho Federal de Educação sobre definição dos cursos de pós-graduação (CARVALHO, 1975).

Segundo MARTINS (1991), até os anos 60, o desenvolvimento da pósgraduação brasileira, além de bastante modesto, fez-se de forma quase espontânea, segundo tendências ou padrões próprios a cada instituição universitária. Nessa época, já existia um número importante de cursos ligados às profissões da saúde, sendo que cerca de $20 \%$ deles referiam-se às áreas de Higiene e Saúde Pública. A partir de 1964/65, através da CAPES $^{3}$, sentiu-se a ação do Governo Federal no sentido de implantar um determinado modelo de pós-graduação que foi buscar inspiração nos moldes norte-americanos.

Conforme CÓRDOVA (1986) os primeiros programas formalmente reconhecidos tinham um caráter nitidamente profissionalizante. Para WANDERLEY (1984), devido às influências de modelos do exterior (francês, alemão e norteamericano) um dos problemas crônicos da Universidade, nessa época, foi o de conciliar o ensino profissional com a atividade científica. Na França, a atividade

\footnotetext{
3 Fundação Coordenação de Aperfeiçoamento de Pessoal de Nível Superior é uma fundação pública sob supervisão do Ministério da Educação e do Desporto (MEC), criada pelo Decreto número 29.741, de 11 de julho de 1951 e transformada em fundação conforme a Lei 8.405, de 09 de janeiro de 1992, com o objetivo principal de subsidiar o MEC na formulação das políticas de pós-graduação, coordenando e estimulando - mediante a concessão de bolsas de estudos, auxílios e outros mecanismos - a formação de recursos humanos altamente qualificados para a docência em grau superior, a pesquisa e o atendimento da demanda profissional dos setores públicos e privados.
} 
científica estava vinculada aos institutos independentes e nos Estados Unidos, que assimilaram o modelo alemão, houve uma inovação na formação dos cientistas nos cursos de doutoramento, credenciando-os para atividades universitárias e outras externas, diferentemente dos modelos europeus.

Com esse novo conceito de pós-graduação lato sensu e stricto sensu, em vigor no país, e atendendo à Portaria GR/885 de 25/8/69 que regula o regime de pós- graduação na USP, a FSP transformou os antigos cursos de pós-graduação em Curso de Saúde Pública para Graduados ${ }^{4}$ e criou, em 1970, os cursos de Mestrado e Doutorado, reconhecidos pelo CFE/MEC em 6/8/73, conforme Parecer CFE no 1266/73 (D.O.U. de 9/10/73) dando continuidade ao que vinha fazendo. Foi então, a primeira instituição no país a oferecer mestrado e doutorado em saúde pública (USP, 1994).

A partir desse momento a FSP passou a conviver com dois níveis de pósgraduação: a lato sensu e a stricto sensu. A lato sensu, representada pela Especialização em Saúde Pública como herdeira da tradição dos cursos de saúde pública da FSP, com grande interface junto ao Mestrado, sendo pré-requisito para o mesmo até 1989. Na Especialização os alunos eram procedentes, e na maioria das vezes indicados, por instituições públicas de saúde e já com experiência de trabalho em saúde pública, sendo previsto seu retorno à instituição em cargos que exigiam essa qualificação.

Ainda na década de 70, a FSP teve papel importante no preparo de pessoal para assumir novos cargos no serviço público de saúde. A Reforma da Secretaria de Estado da Saúde de São Paulo (SESSP), durante a segunda gestão do Prof. Walter Leser, teve como uma de suas estratégias a formação de sanitaristas, o que motivou convênio entre a FSP e a SESSP. Foram realizados cursos semestrais que possibilitaram o preenchimento de 315 vagas do quadro de médicos sanitaristas no espaço de três anos. Era o chamado "curso curto", pela sua semelhança ao curso de especialização que na época tinha um ano de duração em período integral. O "curso curto" não era aceito como pré-requisito para a inscrição no mestrado, definindo-se claramente para o preparo de profissionais, na sua

\footnotetext{
4 Em 1982, os Cursos para Graduados passaram a ser denominados de Curso de Especialização em Saúde Pública.
} 
grande maioria médicos, que seriam absorvidos pela rede de serviços de saúde da SESSP.

A especialização dava acesso ao mestrado e foi sempre considerada, pelos professores da FSP, como o "carro chefe", "o nosso curso", "o logotipo" da FSP.

Estudo sobre o perfil dos alunos do Curso de Especialização em Saúde Pública da FSP, desenvolvido por VASCONCELLOS e NARVAI (1997), concluiu que, no período 1985 a 1994, ocorreram significativas alterações nas características dos alunos do Curso, "destacando-se o progressivo afastamento da categoria profissional de médicos e o crescente interesse dos assistentes sociais e psicólogos". Verificaram também que a FSP, outrora formadora de especialistas em Saúde Pública vindos das mais diferentes macroregiões brasileiras e mesmo do exterior, (América Latina e África Portuguesa) não conseguiu manter tal abrangência uma vez que a clientela do Curso vem se restringindo, gradativamente, a alunos oriundos do município de São Paulo. Tal característica parece resultar, também, do fato de ter havido, nos anos 70 e 80 , significativa expansão no número de cursos de especialização em Saúde Pública, os quais passaram a se desenvolver em praticamente todas as macro regiões do Brasil.

Ainda para esses autores, as mudanças no sistema de saúde, "intensificadas com o processo de descentralização e reorganização que ganharam expressão formal com a criação do Sistema Único de Saúde (SUS), em 1988, influiriam decisivamente nos tipos de especialistas em saúde pública requeridos nesse novo contexto histórico. O antigo sanitarista, em cuja formação têm insistido boa parte dos cursos de especialização em Saúde Pública, inclusive o da FSP, vem encontrando crescentes dificuldades de inserção nas organizações sanitárias surgidas com a municipalização do sistema. Em conseqüência, esse Curso, e cursos similares, vêm perdendo a sintonia com as novas realidades".

Hoje podemos afirmar que os cursos de pós-graduação stricto sensu do país estão basicamente preparando profissionais para universidades públicas (docentes e pesquisadores) e para serviços ou fundações igualmente públicas (GOLDENBERG, 1997). O Ministério da Saúde e as secretarias de saúde são 
instituições que absorvem grande parte dos egressos e, por sua vez, demandam às escolas o atendimento de suas necessidades de formação de pessoal para a composição de seus quadros. Esse movimento tem levado a uma intensa participação do Ministério e das secretarias nas políticas de formação de recursos humanos que, como aponta KISIL (1994) vem se concretizando particularmente por intermédio da Faculdade de Saúde Pública da Universidade de São Paulo e da Escola Nacional de Saúde Pública/Fundação Oswaldo Cruz/Ministério da Saúde (ENSP).

Segundo esse mesmo autor as escolas de saúde pública na América Latina surgiram basicamente para atender às demandas dos ministérios e secretarias de saúde, e possuem duas características marcantes: uma profunda relação, chegando em vários casos, à dependência total dos serviços de saúde pública governamentais (das 14 escolas existentes na América Latina, seis pertencem aos ministérios ou secretarias de saúde); e uma outra característica que se refere à reprodução de modelos de ensino desenvolvidos pelas escolas de saúde pública dos Estados Unidos.

Essa aproximação com os organismos nacionais - Ministério e secretarias - leva no Brasil, as conferências nacionais de saúde e de recursos humanos para a saúde, promovidas pelo Ministério da Saúde a se constituírem um foro privilegiado de debate da problemática específica da área. A VIII Conferência Nacional de Saúde, por exemplo, constituiu-se no marco histórico de um processo que se convencionou chamar de Movimento da Reforma Sanitária. Realizada em 1986, ocorreu no início de uma nova etapa de formulação das políticas de saúde no Brasil, e até mesmo das políticas públicas em geral. O Movimento da Reforma Sanitária trouxe como princípios a universalização, a eqüidade e a democratização da saúde, e propôs as grandes questões reorganizativas do setor, centradas na idéia e proposta do Sistema Único de Saúde - SUS, aprovado com a promulgação da nova Constituição Brasileira, em 1988 (MINISTÉRIO DA SAÚDE,1994a).

A I Conferência Nacional de Recursos Humanos para a Saúde, realizada também em 1986, e gerada na VIII Conferência, teve como tema central "Política de Recursos Humanos rumo à Reforma Sanitária". Seu papel principal foi o de consolidar as análises sobre a política de desenvolvimento de recursos humanos 
para o setor saúde e propor a agenda para o movimento da Reforma Sanitária, visando a desejada implantação do SUS. Foi ponto de unanimidade nessa ocasião a necessidade de uma articulação mais estreita entre as instituições que prestam serviços e aquelas que formam pessoal de saúde. No que diz respeito à capacitação de pessoal em nível de pós-graduação, as recomendações apresentadas foram as seguintes:

"A pós-graduação deve flexibilizar-se em termos de conteúdos e direção, de modo a permitir atender adequada e simultaneamente às especificidades das demandas originadas no Sistema Único de Saúde e que dizem respeito à capacitação para a docência e pesquisa. Três tipos gerais de demanda devem ser atendidas prioritariamente como estratégia de desenvolvimento do Sistema:

- a formação dos quadros de instituições, encarregadas da formação de novos profissionais nos níveis de graduação e pós-graduação;

- a formação dos profissionais que compõem os quadros das instituições prestadoras de serviços, encarregadas da realização da pesquisa intermediária que permita a reavaliação e a readequação contínuas dos serviços, e a disseminação do conhecimento crítico que dê ao Sistema o dinamismo que corresponda às necessidades de saúde da população;

- a formação de quadros de instituições de pesquisa, envolvidos indiretamente com a docência e a prestação de serviços" (MINISTÉRIO DA SAÚDE, 1993).

A I Conferência identificou, ainda, a necessidade premente de qualificação acelerada como estratégia inicial do desenvolvimento do SUS, e de se criar formas de estímulo e condições para que os profissionais oriundos dos serviços se interessem e possam fazer estudos de especialização e pós-graduação (MINISTÉRIO DA SAÚDE, 1993). 
A II Conferência Nacional de Recursos Humanos, em 1993, trouxe o alerta de que "a situação dos serviços de saúde e das práticas profissionais está caótica e comprometendo a própria idéia do SUS". Apresenta propostas relativas às políticas de preparação de pessoal que tem como preocupação central o comprometimento das instituições universitárias com o processo de Reforma Sanitária, o resgate do papel das universidades enquanto centros de formação e de produção de conhecimento, e o direcionamento da pesquisa para a realidade social, na tentativa de superar a dicotomia ainda existente entre a universidade e a realidade vivenciada pelas comunidades e entre a universidade e o mundo do trabalho (MINISTÉRIO DA SAÚDE, 1994a).

A partir dos textos dessas Conferências podemos observar uma expectativa de que a universidade, enquanto centro de formação e produção de conhecimento, esteja comprometida com o desenvolvimento do SUS. Tentaremos analisar se estas questões estão presentes ou distanciam-se do curso de pósgraduação em saúde pública da FSP, objeto do nosso estudo.

A forte vinculação entre as instituições de formação e de assistência à saúde é portanto histórica, e está remetida às políticas de extensão de cobertura, interiorização de ações de saúde pública e saneamento, integração de serviços de saúde e, posteriormente, à regionalização e hierarquização do modelo sanitário, ocasionando mudanças na formação e utilização de recursos humanos para a área.

Outras instituições governamentais também pressupõem o preparo de profissionais para o desenvolvimento de sua política. Os cursos da FSP acabam sendo pautados por instituições governamentais do setor. Tem sido também referência importante para a FSP os programas propostos por agências internacionais como a Organização Panamericana de Saúde, a Organização Internacional do Trabalho e outras.

A Constituição Brasileira de 1988 atribui ao Conselho Nacional de Saúde, no âmbito do SUS, a ordenação da formação de recursos humanos a partir da apreciação da necessidade social de cursos novos da área da saúde.

Porém no que diz respeito à pós-graduação stricto sensu no Brasil a formação nesse nível de curso para todas as áreas de conhecimento é conduzida 
pelo MEC em particular por uma de suas fundações - a CAPES . O início da pósgraduação stricto sensu acrescentou, portanto, um novo interlocutor para FSP - a CAPES/MEC.

Para a CAPES, os cursos da FSP estão incluídos na área denominada Saúde Coletiva5 ${ }^{5}$, pertencente à "Grande Área - Ciências da Saúde", juntamente com Medicina, Odontologia, Farmácia, Enfermagem, Nutrição, Fonoaudiologia e Educação Física.

A Saúde Coletiva só foi reconhecida como área autônoma, pela CAPES, em 1993. Para BARRETO (1997) "Até então, tínhamos o status de uma área de concentração da área médica. Neste curto espaço de tempo construímos uma identidade própria no interior daquela agência e assumimos posição de destaque no que diz respeito à avaliação global de uma área”.

Até o final da década de 80, existiam 14 cursos de pós-graduação na área de saúde coletiva, sendo nove de mestrado e cinco de doutorado, pertencentes a escolas públicas e concentrados em São Paulo, Rio de Janeiro e Bahia.

GEORGEN (1997) lembra que "Regulamentada a pós-graduação, depois de implantada a reforma universitária de 1968, os programas começam a ser criados num sistema de privilegiamento regional. Desde cedo, a distribuição dos programas pelas regiões inscreveu-se no mesmo mapa das disparidades do desenvolvimento sócioeconômico brasileiro. A maioria dos cursos foi instalada na região sul-sudeste, que também é a mais desenvolvida. Em decorrência da heterogeneidade sócioeconômica e, consequentemente, educativa do Brasil, a pós-graduação ainda se concentra fortemente nos estados e instituições dessa região".

$5 \mathrm{Na}$ década de 70, discussões entre diferentes segmentos da saúde pública, particularmente no Brasil, levaram ao aparecimento de uma tendência de se repensar a saúde numa perspectiva de saúde coletiva. Tentativa de superar a medicalização e o contraste público-privado (NUNES, 1996). Segundo GALLO (1992), foi conduzido com grande participação dos departamentos de medicina preventiva. Atualmente é comum encontrar-se autores que se referem ao campo como "Saúde Pública/Coletiva". Sobre a saúde pública ver: BENCHIMOL, 1990; BERTUCCI, 1997; FERREIRA, 1990; MERHY, 1992; RIBEIRO, 1993; ROSEN, 1994; VASCONCELLOS, 1995. Sobre saúde coletiva ver: ALMEIDA FILHO, 1997 e PAIM e ALMEIDA FILHO, 1998. 
Segundo LOYOLA (1994) "Em 1993, 83\% dos cursos de pós-graduação estavam concentrados nas regiões Sul (14\%) e Sudeste (69\%) contra apenas 17\% das demais regiões ( $2 \%$ no Norte, $11 \%$ no Nordeste e $4 \%$ no Centro Oeste)".Para o campo da saúde pública, no mesmo período essas percentagens são semelhantes (15\% Sul; 70\% Sudeste; 0\% Norte; 10\% Nordeste; e 5\% Centro Oeste). Ressaltamos porém que o primeiro curso na região sul do país só teve início em 1990, sendo portanto recente o desenvolvimento da pós-graduação nessa área, na região sul.

No início da década de 90 houve uma expansão do número de cursos, na área de Saúde Coletiva, com a criação de programas em Minas Gerais, Mato Grosso do Sul, Ceará, Paraná e Rio Grande do Sul, aumentando para 25 - dezessete mestrados e oito doutorados (Quadro 1). Estão ainda em fase de implantação cursos na Universidade Estadual de Feira de Santana e na UFRJ, Pernambuco e Maranhão.

As diferentes denominações e classificações dos cursos nessa área chamam à atenção para a diversidade da área e a interface da saúde pública com outras áreas. Entre os mestrados encontramos, além de cursos em saúde pública e saúde coletiva os de epidemiologia e medicina preventiva. Outros cursos estão tão intimamente associados que, apesar de classificados na categoria "outros multidisciplinar" pela CAPES, são avaliados pelo Comitê da área de Saúde Coletiva, e incluídos no processo de discussão e avaliação desenvolvidos pela Associação Brasileira de Pós-Graduação em Saúde Coletiva (ABRASCO) - é o caso do mestrado e doutorado em Saúde e Ambiente da UFMT, e o mestrado em Saúde Materno-Infantil do IMIP (Pernambuco). Ainda temos cursos não colocados nas situações acima, como os de Enfermagem em Saúde Pública, Odontologia Social, Administração Hospitalar e Sistemas de Saúde, cujos conteúdos provavelmente se aproximam aos de Saúde Coletiva.

Essa origem institucional diversa não somente estabelece recortes diferentes, mas cria possibilidades e características próprias aos cursos. A maioria dos cursos citados surgiram de departamentos de escolas de graduação da área de saúde, principalmente medicina. 
Quadro 1 - Cursos de Pós-Graduação Stricto Sensu em Saúde Coletiva. Brasil, 1997.

\begin{tabular}{|c|c|c|c|c|c|}
\hline $\begin{array}{l}\text { Nome do } \\
\text { Programa }\end{array}$ & Instituição & Nível & $\begin{array}{l}\text { Ano de } \\
\text { início }\end{array}$ & Áreas de concentração & $\begin{array}{l}\text { Conceito avaliação } \\
\text { CAPES } 94 / 95\end{array}$ \\
\hline \multirow[t]{2}{*}{ Saúde Pública } & \multirow[t]{2}{*}{$\begin{array}{l}\text { Faculdade de Saúde } \\
\text { Pública/USP }\end{array}$} & mestrado & 1970 & $\begin{array}{l}\text { "Serviços de Saúde Pública; Administração } \\
\text { Hospitalar; Epidemiologia; Saúde Ambiental; } \\
\text { Nutrição; Saúde Materno-Infantil." }\end{array}$ & $\mathrm{A}$ \\
\hline & & doutorado & 1970 & $\begin{array}{l}\text { "Serviços de Saúde Pública; Administração } \\
\text { Hospitalar; Epidemiologia; Saúde Ambiental; } \\
\text { Nutrição; Saúde Materno-Infantil." }\end{array}$ & A \\
\hline \multirow[t]{2}{*}{ Medicina } & \multirow{2}{*}{$\begin{array}{l}\text { Dep Medicina } \\
\text { Social/FMRP/USP }\end{array}$} & mestrado & 1971 & Medicina Preventiva & $\mathrm{B}$ \\
\hline & & doutorado & 1971 & Medicina Preventiva & $\mathrm{C}$ \\
\hline \multirow[t]{2}{*}{ Medicina } & \multirow{2}{*}{\begin{tabular}{|l|} 
Dep Med \\
Preventiva/FM/USP \\
\end{tabular}} & mestrado & 1973 & Medicina Preventiva & $\mathrm{B}$ \\
\hline & & doutorado & 1973 & Medicina Preventiva & $\mathrm{B}$ \\
\hline \multirow[t]{2}{*}{ Saúde Pública } & \multirow[t]{2}{*}{$\begin{array}{l}\text { Escola Nacional de } \\
\text { Saúde Pública/Fundação } \\
\text { Oswaldo Cruz }\end{array}$} & mestrado & 1977 & $\begin{array}{l}\text { "Epidemiologia; Epidemiologia das Grandes } \\
\text { Endemias; Toxicologia; Saúde do Trabalhador; } \\
\text { Planejamento e Gestão de Sistemas e Serviços de } \\
\text { Saúde; Políticas de Saúde; Saúde e Sociedade; } \\
\text { Saneamento Ambiental; Saúde Mental; " }\end{array}$ & A \\
\hline & & Doutorado & 1980 & $\begin{array}{l}\text { "Epidemiologia; Epidemiologia das Grandes } \\
\text { Endemias; Toxicologia; Saúde do Trabalhador; } \\
\text { Planejamento e Gestão de Sistemas e Serviços de } \\
\text { Saúde; Políticas Sociais; Saúde e Sociedade; } \\
\text { Saneamento Ambiental; Saúde Mental; " }\end{array}$ & A \\
\hline \multirow[t]{2}{*}{ Saúde Comunitária } & \multirow[t]{2}{*}{$\begin{array}{l}\text { Instituto de Saúde } \\
\text { Coletiva/UFBA }\end{array}$} & Mestrado & 1974 & $\begin{array}{l}\text { Epidemiologia, Planificação e Gestão em Saúde, C. } \\
\text { Sociais e Saúde }\end{array}$ & A \\
\hline & & Doutorado & 1989 & Epidemiologia & A \\
\hline \multirow[t]{2}{*}{ Saúde Coletiva } & \multirow[t]{2}{*}{$\begin{array}{l}\text { Instituto de Medicina } \\
\text { Social/UERJ }\end{array}$} & Mestrado & 1974 & $\begin{array}{l}\text { "Epidemiologia; Ciências Humanas e Saúde; } \\
\text { Políticas, Planejamento e Administração em Saúde " }\end{array}$ & A \\
\hline & & doutorado & 1990 & $\begin{array}{l}\text { "Epidemiologia; Ciências Humanas e Saúde; } \\
\text { Políticas, Planejamento e Administração em Saúde " }\end{array}$ & $\mathrm{B}$ \\
\hline \multirow[t]{2}{*}{ Saúde Coletiva } & \multirow{2}{*}{$\begin{array}{l}\text { Dep Medicina Preventiva } \\
\text { e Social/FCM/UNICAMP }\end{array}$} & mestrado & 1985 & Saúde Coletiva & B \\
\hline & & doutorado & 1985 & Saúde Coletiva & $\mathrm{B}$ \\
\hline
\end{tabular}


Quadro 1 - Cursos de Pós-Graduação Stricto Sensu em Saúde Coletiva. Brasil, 1997.

\begin{tabular}{|c|c|c|c|c|c|}
\hline $\begin{array}{l}\text { Nome do } \\
\text { Programa }\end{array}$ & Instituição & Nível & $\begin{array}{l}\text { Ano de } \\
\text { início }\end{array}$ & Áreas de concentração & $\begin{array}{l}\text { Conceito avaliação } \\
\text { CAPES } 94 / 95\end{array}$ \\
\hline Epidemiologia & UNIFESP & mestrado & 1988 & Epidemiologia & $\mathrm{B}$ \\
\hline \multirow{2}{*}{$\begin{array}{l}\text { Saúde da Criança e } \\
\text { da Mulher }\end{array}$} & \multirow{2}{*}{$\begin{array}{l}\text { Fundação Oswaldo } \\
\text { Cruz/Instituto Fernandes } \\
\text { Figueira/RJ }\end{array}$} & mestrado & 1988 & Saúde da Criança e Saúde da Mulher & $\mathrm{B}$ \\
\hline & & doutorado & 1995 & Saúde da Criança e Saúde da Mulher & s/aval \\
\hline Saúde Coletiva & $\begin{array}{l}\text { Centro de Ciências da } \\
\text { Saúde/UEL }\end{array}$ & mestrado & 1990 & Saúde Coletiva & $\mathrm{C}$ \\
\hline Epidemiologia & FM/UFPEL & mestrado & 1991 & Epidemiologia & $\mathrm{B}$ \\
\hline Saúde Coletiva & $\begin{array}{l}\text { Centro de Ciências } \\
\text { Biológicas e da } \\
\text { Saúde/FUFMS }\end{array}$ & mestrado & 1992 & Saúde Coletiva & $\mathrm{D}$ \\
\hline Saúde Pública & $\begin{array}{l}\text { Faculdade de } \\
\text { Medicina/UFMG }\end{array}$ & mestrado & 1994 & Epidemiologia & $\mathrm{B}$ \\
\hline Saúde Pública & $\begin{array}{l}\text { Dep Saúde } \\
\text { Comunitária/Centro de } \\
\text { Ciências da Saúde/UFC }\end{array}$ & mestrado & 1994 & Epidemiologia & $\mathrm{C}$ \\
\hline Saúde Pública & UECE & mestrado & 1994 & $\begin{array}{l}\text { "Políticas e Serviços de Saúde; Saúde Mental em } \\
\text { saúde Pública; Nutrição em Saúde Pública." }\end{array}$ & $\mathrm{D}$ \\
\hline Saúde Pública & UFSC & mestrado & 1996 & $\begin{array}{l}\text { "Epidemiologia; Planejamento e Administração em } \\
\text { Saúde" }\end{array}$ & s/aval \\
\hline Saúde Pública & $\begin{array}{l}\text { Centro de Pesquisa } \\
\text { Aggeu } \\
\text { Magalhães/FIOCRUZ - } \\
\text { NESC/Med } \\
\text { Social/CCS/UFPE }\end{array}$ & mestrado & 1996 & $\begin{array}{l}\text { Epidemiologia Ambiental, Epidemiologia Molecular, } \\
\text { e Planejamento e Gestão de Serviço }\end{array}$ & s/aval \\
\hline
\end{tabular}


Quadro 1 - Cursos de Pós-Graduação Stricto Sensu em Saúde Coletiva. Brasil, 1997.

Cursos avaliados pelo Comitê de Saúde

Coletiva (CAPES), mas classificados

pela CAPES como Outros -

Multidisciplinar:

\begin{tabular}{|c|c|c|c|c|c|}
\hline $\begin{array}{l}\text { Nome do } \\
\text { Programa }\end{array}$ & Instituição & Nível & $\begin{array}{l}\text { Ano de } \\
\text { início }\end{array}$ & Áreas de concentração & $\begin{array}{c}\text { Conceito avaliação } \\
\text { CAPES 94/95 }\end{array}$ \\
\hline $\begin{array}{l}\text { Saúde Materno- } \\
\text { Infantil }\end{array}$ & $\begin{array}{l}\text { Instituto Materno- } \\
\text { Infantil/PE }\end{array}$ & Mestrado & & & $\mathrm{C} / \mathrm{N}$ \\
\hline Saúde e Ambiente & $\begin{array}{l}\text { Instituto de Saúde } \\
\text { Coletiva/UFMT }\end{array}$ & Mestrado & 1993 & $\begin{array}{l}\text { "Etnobotânica; Farmacologia; Química Ambiental; } \\
\text { Saúde e Sociedade; Epidemiologia e Processo } \\
\text { Saúde-Doença." }\end{array}$ & $\mathrm{C} / \mathrm{N}$ \\
\hline Saúde e Ambiente & & Doutorado & 1993 & $\begin{array}{l}\text { "Etnobotânica; Farmacologia; Química Ambiental; } \\
\text { Saúde e Sociedade; Epidemiologia e Processo } \\
\text { Saúde-Doença." }\end{array}$ & \\
\hline
\end{tabular}

obs: Foram registrados apenas os cursos apontados pala CAPES como sendo da área de Saúde Coletiva. Não constam cursos na área de Saúde Coletiva em Enfermagem e Odontologia, por exemplo.
Obs: Cursos multiprofissionais, com exceção dos da FMRP/USP e FM/USP, destinados a médicos. $O$ mesmo acontecia, até 1990, com o curso da

UNICAMP quando passou a ser multiprofissional e substituiu sua denominação anterior (Med com área de conc em S Coletiva).

Fonte: NUNES,E.D. COSTA,P.S. da (1997) e NUNES,E.D.(1997) CAPES (disponível em http://www.capes.gov.br, obtido em março 1998) consulta telefônica ao Prof Maurício Barreto (abril/98) 
Apenas duas são as escolas no Brasil com vocação exclusiva para a saúde pública, a FSP e a ENSP. Porém, devemos ressaltar as especificidades de criação de cada uma delas.

A Fundação Oswaldo Cruz$^{6}$ é a principal instituição do Ministério da Saúde, de formação de recursos humanos em saúde no país. A ENSP, uma de suas unidades técnico-científicas, "nasceu com o advento da Lei no 2312 de 3 de setembro de 1954, que estabeleceu normas gerais sobre defesa e proteção da saúde da população brasileira". Ao criar a ENSP, o Ministério da Saúde tinha como objetivo contar com o apoio sistemático e especializado para a formação dos profissionais mais qualificados de saúde pública, que passariam a assumir o comando e o gerenciamento na administração pública dos serviços de saúde. Desenvolve hoje atividades de ensino, mediante cursos multiprofissionais nos seguintes níveis: mestrado e doutorado, criados respectivamente em 1977 e 1980; especializações em saúde pública e em áreas específicas da saúde pública; e residência (MINISTÉRIO DA SAÚDE, 1994b).

A FSP, ao longo de sua existência sofreu várias alterações estruturais. Em 1931 esteve subordinada à Secretaria da Educação e Saúde Pública como "Escola de Higiene e Saúde Pública”. Posteriormente (1938), com a criação da USP, foi um instituto complementar da Universidade. Em 1945 atingiu sua autonomia como uma das 33 unidades da USP, denominando-se à época "Faculdade de Higiene e Saúde Pública”, e em 1969 "Faculdade de Saúde Pública” (CANDEIAS, 1984; USP, 1989). Segundo KISIL (1994) foi a primeira escola da saúde pública da América Latina a pertencer a uma universidade. Com a conquista da autonomia podemos imaginar que tenham surgido questões referentes à necessidade da

6 Criado no início do século (1900), o Instituto de Manguinhos posteriormente Fundação Oswaldo Cruz "constitui-se num dos principais suportes técnico-científicos às atividades do Sistema Único de Saúde (SUS). É uma fundação pública, vinculada ao Ministério da Saúde. Desenvolve múltiplas e complexas atividades, que incluem pesquisa básica e aplicada, desenvolvimento tecnológico de produtos e processos, produção de imunobiológicos e fármacos, controle de qualidade dos produtos consumidos pela população, formação de recursos e prestação de serviços assistenciais de referência"

Possui as seguintes Unidades Técnico-Científicas: Casa Oswaldo Cruz; Centro de Informação Científica e Tecnológica; Centro de Pesquisa Aggeu Magalhães; Centro de Pesquisa Gonçalo Moniz; Centro de Pesquisa René Rachou, Escola Nacional de Saúde Pública; Escola Politécnica de Saúde Joaquim Venâncio; Instituto de Tecnologia em Fármacos - Far-Manguinhos; Instituto Fernandes Figueira; Instituto Nacional de Controle de Qualidade em Saúde; Instituto Oswaldo Cruz; e Instituto de Tecnologia em Imunobiológicos - Bio-Manguinhos. (MINISTÉRIO DA SAÚDE, 1994 b). 
Faculdade se repensar a partir de uma lógica universitária, principalmente se consideramos sua característica de possuir como interlocutores os serviços de saúde e os organismos internacionais do campo da saúde pública, distinguindo-se, assim da ENSP, que foi criada pelo Ministério da Saúde.

\section{A FACULDADE DE SAÚDE PÚBLICA: ATIVIDADES DE EXTENSÃO UNIVERSITÁRIA, PESQUISA E ENSINO}

A FSP possui cinco departamentos: Prática de Saúde Pública (HSP), Epidemiologia (HEP), Saúde Ambiental (HSA), Saúde Materno Infantil (HSM), e Nutrição (HNT). Este último mais diretamente responsável pela formação de nutricionistas. Os dois departamentos com maior número de professores são os de Prática de Saúde Pública e Epidemiologia, que absorvem maior número de atividades e alunos.

A FSP mantém ainda dois centros de treinamento o Centro de Saúde Geraldo de Paula Souza, o primeiro centro de saúde do Brasil, criado em 1925 e o Serviço Especial de Saúde de Araraquara, criado em 19477 como centro rural de aprendizado da então Faculdade de Higiene e Saúde Pública.

A seguir procuraremos brevemente apresentar algumas considerações sobre as atividades de extensão universitária, ensino e pesquisa da FSP procurando chamar à atenção para características que a nosso ver podem influenciar diretamente o desenvolvimento dos cursos de mestrado e doutorado na Faculdade, uma vez que refletem como a FSP prioriza ou trabalha com essas três finalidades de uma unidade universitária de ensino.

\section{Atividades de Extensão}

A expressão serviços, ou extensão, segundo BALBACHEVSKY, (1995) "tende a abranger uma variedade bastante grande de atividades: cursos e palestras de extensão e difusão cultural, consultorias, atendimento a clientes e prestação de

\footnotetext{
7 Universidade de São Paulo. Processo no 18238-62.
} 
serviços em geral (pagos ou não). Nessa rubrica costumam-se classificar todas as atividades que não são redutíveis aos papéis mais tradicionais do professor e pesquisador".

As atividades de extensão universitária são desenvolvidas de forma intensa na FSP. Na tentativa de criar um banco de dados, para conhecer e divulgar as atividades de extensão dos docentes, excetuando-se cursos, foi efetuado um levantamento junto aos professores, pela Comissão de Cultura e Extensão Universitária, referente ao segundo semestre de 1991. Esse levantamento mostrou a atividade de consultoria e assessoria a órgãos públicos de prestação de serviços de saúde como a mais freqüente ${ }^{8}$, sendo o Departamento de Prática de Saúde Pública o que apresentou o maior número dessas atividades.

São restritas as fontes de informações que permitam qualificar mais precisamente a extensão na FSP, sendo uma preocupação na FSP qual seria a melhor forma de atribuir valor a essas ações.

Um possível indicador da intensidade das atividades de extensão na FSP pode ser o fato da Faculdade ser na USP a unidade que possui o maior número de Núcleos ou Centros de Apoio à Cultura e Extensão Universitária9 eqüivalendo a 70\% dos núcleos da Universidade.

A USP através da Comissão Permanente de Avaliação, iniciou em 1993, processo de avaliação departamental em todas as suas unidades. Esse processo

\footnotetext{
8 Universidade de São Paulo. Faculdade de Saúde Pública. Atividades de Cultura e Extensão dos docentes da FSP/USP $-2^{\circ}$ semestre/1991 São Paulo; 1991 [Relatório]. Obs: Não existem dados disponíveis para os anos seguintes.

9 Apoio à Pesquisa - (NAPs) - Núcleo de Pesquisas Epidemiológicas em Nutrição e Saúde NUPENS; Núcleo de Pesquisa Taxonômica e Sistemática em Entomologia Médica - NUPTEM; Núcleo de Pesquisa em Direito Sanitário. Apoio à Cultura e Extensão Universitária - (NACEs) Núcleo de Assistência Médico-Hospitalar - NAMH; Núcleo de Estudos em Poluição e Saúde; Núcleo de Estudos das Práticas de Saúde Coletiva na Construção de Sistemas Locais de Saúde CONSILOS; Núcleo de Informações em Saúde Ambiental - NISAM; Núcleo de Estudos do Crescimento e do Desenvolvimento Humano - CDH; Núcleo de Apoio ao Desenvolvimento de Sistemas de Saúde - NUDES; Núcleo de Apoio à Promoção e Educação em Saúde Escolar NUPESE; CENTROS: Centro de Estudos do Crescimento e Desenvolvimento do Ser Humano; Centro de Estudos em Dinâmica Populacional - CEDIP; Centro de Estudos de Alimentação e Nutrição no Esporte - CEANE; Centro de Estudos e Pesquisas sobre o Envelhecimento - CEPE ; Centro de Estudos e Desenvolvimento de Pesquisa Social em Saúde; Centro de Estudos sobre Medicina Tradicional e Terapias Alternativas em Saúde Pública - CEMTASP; Centro de Estudos e Documentação de Educação, Comunicação e Promoção de Saúde do Trabalho - CEDECOM/ST. Núcleo de Investigação em Vigilância da Tuberculose - NIVTb; Núcleo de Estudos e Pesquisas de Sistemas de Saúde - NEPESS.
} 
envolve uma auto avaliação e o parecer de pares externos à unidade, com a apresentação final de conceitos para as atividades de pesquisa, ensino e extensão. Os departamentos da FSP foram avaliados como regulares em pesquisa, bons em relação ao ensino e excelentes quanto à extensão ${ }^{10}$.

Para o Departamento de Prática de Saúde Pública os pares externos firmaram a importância de reconhecer a vocação do Departamento e da FSP para a prestação de serviços de saúde pública, tendo a Comissão feito as observações transcritas a seguir ${ }^{11}$ :

"De uma maneira geral, podemos afirmar que a FSP tem, permanentemente, estado atenta às modificações da organização do sistema de saúde e procurado adequar seus cursos, em particular o de especialização, às realidades emergentes. Cursos de extensão tem sido oferecidos com regularidade, atendendo a demandas específicas que se aceleram com o processo de municipalização".

"Cabe destacar que o Departamento é intensamente solicitado por organismos oficiais e municipalidades para que forneça subsídios para a implementação das políticas de saúde. Essa colaboração compreende um grande $\mathrm{n}^{0}$ de consultorias e assessorias, levando, por vezes, ao afastamento de docentes para atuarem diretamente em órgãos oficiais, responsáveis pela saúde. Estabelece-se, assim, um produtivo intercâmbio de informações e experiências, num exemplo evidente de atenção da Universidade para os grandes problemas da população".

Apesar desse reconhecimento, a Comissão chama a atenção para uma possível conseqüência dessa dedicação para as atividades de pesquisa.

"Há um excessivo envolvimento com atividades de assessoria e

\footnotetext{
10 Siqueira AAF, Dallari SG, Ribeiro H Grupo de Trabalho sobre a Departamentalização da Faculdade de Saúde Pública São Paulo; 1998 [Parecer]

11 Universidade de São Paulo. Comissão Permanente de Avaliação Relatório Final da Comissão de Avaliação Departamental referente à Avaliação do Departamento de Prática de Saúde Pública São Paulo; 1995 [Relatório]
} 
consultoria. A implementação de políticas de saúde junto às municipalidades e órgãos governamentais é apresentada como uma vocação do Departamento, assumindo um papel de substituto à produção científica mais tradicional. Não há, no entanto, qualquer empenho para avaliar os resultados desse esforço de interação com os setores externos nem uma análise crítica dessa atuação. Não é possível identificar os progressos do conhecimento - científico, tecnológico, político, ou filosófico - que derivam dessa ação governamental".

\section{Pesquisa}

As atividades de pesquisa parecem ser as menos desenvolvidas da FSP e foram no processo de avaliação dos departamentos, como já citamos, consideradas regulares, foram as que receberam menos comentários favoráveis em todos os departamentos.

Estas críticas estão associadas à baixa produtividade dos docentes medida pelo número de publicações, principalmente em revistas indexadas internacionais.

Quanto às linhas de pesquisa, a FSP já chegou a apresentar para a CAPES uma relação de mais de 100 linhas, com uma grande variedade temática. A CAPES em suas avaliações bianuais, tem solicitado à FSP que o número de linhas seja limitado e as linhas revistas. Algumas dessas linhas não apresentam nenhum projeto em andamento, outras se restringem ao tema de um projeto e outras se caracterizam como área de conhecimento, uma vez que abrangem amplas possibilidades de temas específicos. Dúvidas ou diferentes concepções do que significa uma linha de pesquisa são questões que surgem em reuniões e discussões na FSP. Segundo a CAPES (Avaliação Biênio 92/93): "Parece que é dada ampla liberdade aos pesquisadores para encaminhar às agências financiadoras, do modo que considerarem adequado, os títulos das linhas às quais estão associados"

A tarefa de compilar e organizar as linhas de pesquisa da Faculdade era 
realizada pela Biblioteca da FSP, que fazia levantamentos a cada dois anos, até 1989, quando esse procedimento foi interrompido sendo retomado entre 1992 e 1994. A nosso ver a Faculdade tem ampliado a discussão ou preocupação em ordenar suas linhas de pesquisa provavelmente estimulada pela importância dada pelas agências de fomento a esse aspecto e pelas críticas de avaliações departamentais. Além da Biblioteca outras comissões e principalmente a CPG tem assumido mais essa questão.

No segundo semestre de 1996, a CPG nomeou um "Grupo de Trabalho sobre definição de linhas de pesquisa". O grupo solicitou ${ }^{12}$ aos departamentos que fizessem uma revisão, considerando que o assunto é de vital importância para a relação FSP - agências financiadoras, e visando a "possibilidade de criação de um banco de dados ligado à rede, com informações sobre publicações, projetos e pesquisas em andamento, o que facilitaria a vida acadêmica e faria parte dos planos desta Unidade". Nesse processo de revisão alguns departamentos agregaram linhas, havendo então uma redução.

No ano de 1997, pela primeira vez para o processo seletivo de alunos ao mestrado e doutorado os nomes dos professores orientadores foram listados com suas respectivas linhas de pesquisa e assim apresentados aos alunos. Essa listagem tem formas de apresentação diferentes conforme o departamento, indicando formas de organização e fases de revisão diferentes. O HNT apresenta cinco linhas e depois os nomes dos docentes são relacionados às linhas; o HSP lista os nomes dos docentes com suas respectivas linhas, dando a impressão de existir cerca de 80 linhas de pesquisa, pois não há nenhuma uniformidade na definição de linhas; O HEP, HSM e HSA listam os professores com suas linhas, mas já se percebe que algumas linhas permitem o agrupamento de vários professores. Como exemplo pode ser vista, no Anexo 1, as relações do HSP e do HNT.

\section{Ensino}

O núcleo central das atividades de ensino da FSP é a pós-graduação stricto sensu e lato sensu em saúde pública. Em nível de graduação a FSP ministra o curso de Nutrição, primeiro a ser desenvolvido no país, criado em 1940

12 (Of.09/1/97 - Grupo de Trabalho) 
(CANDEIAS, 1984). A inserção desse curso na FSP mereceria um estudo específico, e não nos deteremos neste assunto.

A FSP tem desenvolvido diferentes cursos tanto em nível de pósgraduação lato sensu como de extensão universitária - aperfeiçoamento, atualização e difusão cultural. Nos últimos dois anos a FSP ofereceu especializações de longa duração/USP ${ }^{13}$ em Saúde Pública; Administração de Serviços de Saúde - Administração Hospitalar; Engenharia em Saúde Pública e Ambiental; Enfermagem de Saúde Pública; Promoção da saúde e Odontologia em Saúde Coletiva e cursos de especialização de curta duração/USP ${ }^{14}$, que segundo a Comissão de Cultura e Extensão Universitária (CCEx) oferecidos regularmente são: Estatísticas de Saúde; Controle Ambiental; Educação Ambiental; Engenharia de Controle da Poluição Ambiental; Engenharia de Saneamento Básico; Gestão Ambiental e Entomologia Médica.

Estão ainda em discussão nos departamentos os cursos de especialização em Política, Planejamento e Administração em Saúde; e Epidemiologia, entre outros.

Esses cursos algumas vezes são desenvolvidos de forma regionalizada, sendo ministrados em municípios do interior de São Paulo. Na FSP estas especializações de curta duração até 1996, em alguns casos estão subordinadas à CCEx e não à CPG. Diferentemente do preconizado pela CAPES, na USP, poderiam ser subordinados à CCEx e a CPG. As razões para essa preferência podem ser várias e mereceriam reflexão mais aprofundada.

Podemos afirmar que existe uma tendência de oferta de maior número de especializações com ênfase em diferentes áreas, principalmente após as já comentadas mudanças ocorridas na demanda ao curso de especialização em saúde pública. Os cursos destinados a formar sanitaristas com um perfil mais generalista ainda têm sido ministrados, porém de forma regionalizada e por convênio como os de "Saúde Publica para o SUS", em Santo André, São Paulo, Presidente Prudente, atendendo a demandas dos municípios. Neste momento está ocorrendo o $2^{\circ}$ Curso

13 Cursos de longa duração/USP devem ter duração mínima de dois semestres, e carga horária total não inferior a 720 horas (Resolução CoPGr 3766 de 26.12.90).

14 Cursos de especialização de curta duração/USP (carga horária entre 360 e 720 horas). 
para Gerentes do Sistema Local de Saúde (Curso de Difusão Cultural) em convênio com a SESSP e o COSEMS, atendendo à demanda desses órgãos para a capacitação gerencial tendo em vista a construção de um modelo descentralizado de gestão em saúde.

Além desses cursos, foram ministrados, entre 1990 e 1997, 120 diferentes cursos de extensão, com a média de 783 alunos por ano15. Nesse período os cursos oferecidos de forma mais regular também segundo a CCEx foram na modalidade aperfeiçoamento: Biologia e Identificação de Culicídeos de importância em Saúde Pública; Doenças Sexualmente Transmissíveis; e Direito Sanitário atualização: Epidemiologia das Doenças Transmissíveis; Epidemiologia das Doenças Cardiovasculares; Introdução à Bioestatística; Introdução ao Direito Sanitário; Análise de Regressão Multivariada e Análise de Sobrevivência - difusão cultural: Uso da $10^{\mathrm{a}}$ Revisão da Classificação Internacional de Doenças.

No Anexo 2 encontra-se relação dos cursos de extensão oferecidos no período. Podemos observar uma grande diversidade nas atividades de ensino na FSP, abrangendo número expressivo de alunos, tendo em comum a preocupação com o preparo de profissionais para o mercado de trabalho, predominantemente no serviço público.

Observa-se, então, que sempre houve um movimento de resposta às demandas sociais, em nosso caso de saúde, articulados pelas instituições executivas e de formação, que interferem diretamente na oferta e procura de cursos na área de saúde pública, inclusive de pós graduação.

A pós-graduação stricto sensu, objeto deste estudo, será descrita mais detalhadamente no próximo capítulo. É o curso mais antigo do país nessa modalidade, e o que tem formado maior número de profissionais. Possui corpo docente e discente multiprofissional. Os alunos são predominantemente do sexo feminino, com idade média de 33 e 38 anos para o mestrado e doutorado respectivamente. O número de professores está em torno de 100. Com seis áreas de concentração, possui cerca de 120 disciplinas eletivas oferecidas tanto para o doutorado como para o mestrado. Para o mestrado em 1991 foram introduzidas

\footnotetext{
15 Relatórios anuais da Seção de Alunos/FSP/USP, 1990 a 1997.
} 
disciplinas obrigatórias eqüivalendo atualmente a 21 créditos (315 horas). Tem sido submetida periodicamente às avaliações da CAPES e julgamos conveniente destacar essas avaliações, para melhor compreensão dos objetivos deste estudo. Doravante quando utilizarmos a expressão pós-graduação estaremos nos referindo aos cursos de mestrado e doutorado.

\section{Avaliação da Pós-Graduação Sricto Sensu da FSP}

As avaliações bienais da CAPES ${ }^{16}$, desde 1983, tem conferido nível "A" ao Curso da FSP e o consideram "um importante programa de pós-graduação, com inestimável contribuição à área da saúde pública, corpo docente de alta qualificação e boa produção científica". Dos 22 cursos avaliados, nove tiveram nível $\mathrm{B}$, oito nível $A$, três $C$ e dois $D$ (Quadro 1). Estas informações referem-se à última avaliação divulgada até a fase final de coleta de dados deste estudo, correspondendo ao biênio 94/95. Neste momento, abril/98, está se aguardando a divulgação dos resultados do biênio 96/9717. As críticas, indicadas nas avaliações aos cursos da FSP, ao longo desses anos, têm-se concentrado principalmente nos seguintes aspectos:

- número excessivo de linhas de pesquisa, algumas superposições, linhas com nenhum projeto e linhas que se confundem com projetos de pesquisa;

\footnotetext{
16 Para fins de credenciamento todos os cursos de pós-graduação do país são avaliados pela CAPES desde 1975. A avaliação é feita a cada dois anos e reúne comissões de consultores científicos, formadas por docentes e pesquisadores nacionais por áreas/sub-área do conhecimento que, com base em relatórios anuais enviados pelos cursos à CAPES, relatórios de visitas de especialistas aos programas e outras informações complementares realizam a avaliação periódica do desempenho da pós-graduação. Cada curso é avaliado dentro de sua própria evolução e comparado com seus congêneres de área/subárea. $O$ resultado dessa análise comparativa é expresso numa escala conceitual de cinco letras que se inicia pelo "A", atribuído aos programas de melhor nível e finaliza pelo "E", conferido aos cursos de desempenho pouco aceitável" (MARTINS R C, 1991 e CAPES 1982) Ao longo do tempo, a CAPES foi se reformulando em sua política de apoio e avaliação dos cursos. O banco de dados foi informatizado em 1980; e as avaliações que no início enfatizavam critérios quantitativos passaram a incorporar indicadores de natureza qualitativa (CAPES, 1982).

17 Os critérios de avaliação da CAPES para o biênio 96/97 foram revistos e a classificação dos programas de pós-graduação passou a ser composta de sete níveis de conceitos - de 1 a 7 . (CAPES. Ata da reunião do Conselho Técnico Administrativo de 16/04/98 www.capes.gov.br).
} 
- pouca participação discente em publicações e pequena integração dos alunos em projetos e linhas de pesquisa;

- excessivo quadro de disciplinas oferecidas;

- excessivo tempo médio de titulação especialmente no mestrado;

- endogenia na formação da equipe docente do curso; e

- relação orientador/orientando discretamente elevada para o mestrado, observando-se excesso para alguns orientadores.

Segundo a avaliação referente ao biênio 1992/93, foi considerado pelos consultores da CAPES que "para crescer em qualidade o curso precisa criar elementos de dinamismo, dada a estabilidade que se concentra no corpo de professores". As recomendações apresentadas pela comissão avaliadora nessa ocasião foram as seguintes:

- "através do colegiado de doutores avaliar as linhas e projetos de pesquisa a fim de organizar melhor esta atividade essencial.

- apesar do regulamento da USP prever 60 meses tanto para o mestrado como para o doutorado, tentar rever também as finalidades do mestrado sobretudo para os alunos que vão fazer doutorado e tentar diminuir o tempo. Será que 10 anos para pós-graduação não são excessivos para o estudante e para o País?".

A síntese da avaliação, biênio 94/95, torna a chamar a atenção para "um certo estacionamento no processo evolutivo do curso" e para a "necessidade de reorganizar suas linhas de pesquisa e atualizar sua estrutura curricular".

As avaliações CAPES não devem ser vistas como único procedimento de avaliação ao qual devem estar submetidos os cursos de pós-graduação. Para 
AMORIM (1992), "o relatório CAPES, enquanto instrumento quase que exclusivo de avaliação, tornou-se frágil diante da necessidade de se realizar uma avaliação de forma mais abrangente, pela qual se possa caracterizar a história de cada Programa, sua produção e o impacto do curso em seu contexto."

As críticas ao processo avaliativo da CAPES, apresentadas por esse autor, prendem-se ao fato do mesmo ser exógeno aos programas avaliados, tecnicista, burocrático, e classificatório, privilegiando as informações sobre o produto em relação ao processo. Ressalta que "a avaliação não pode ser usada como instrumento de desqualificação dos programas, mas como um instrumento pedagógico necessário à correção e superação de determinados entraves de natureza financeira, administrativa e acadêmica postos como desafios no caminho da melhoria dos cursos de pós-graduação no Brasil". Porém lembra que "a avaliação da CAPES precisa ser compreendida também a partir das contradições existentes no sistema de ensino superior vigente no país, um sistema que está calcado na falta de participação e de reflexão dos grandes temas nacionais na área social, educacional e acadêmica. Isto faz com que a comunidade universitária fique sem tomar decisões que representem mudanças no ambiente da própria universidade".

Segundo SAUL (1994) "os críticos da pós-graduação são unânimes em considerar a importância e a necessidade de avaliar esse grau de ensino. Os dados de avaliação poderiam servir a múltiplos propósitos: orientação de decisões de política educacional e econômica para o setor ou, ainda, o questionamento da eficiência e, sobretudo, da eficácia dos cursos de pós-graduação. Numa perspectiva mais prática, a avaliação pode responder a problemas imediatos de direcionamento da ação em cada curso".

Os processos de avaliação do ensino superior no Brasil tem ocorrido também em outros foros. A Associação Nacional de Pós-Graduação e de Pesquisa em Educação (ANPEd), por exemplo, tem debatido a questão do processo avaliativo da CAPES e elaborou, em 1987, uma contraproposta avaliativa a ser realizada em quatro fases: autoavaliação, um momento de autocrítica envolvendo docentes, discentes e pessoal administrativo; avaliação interpares; interprogramas; e avaliação da comissão de consultores da própria CAPES (AMORIM, 1992). 
Apesar das inúmeras gestões da ANPEd para que a nova sistemática, aprovada pelo coletivo dos programas, fosse assumida pela CAPES, o projeto de convênio CAPES/ANPEd, para testagem da sistemática, não se efetivou" (SAUL, 1997). Conforme registra Fávero, citado por essa autora "por dificuldades financeiras e políticas, apesar de apoiada pela CAPES, a proposta não chegou sequer a ser testada".

SAUL (1994) ao repensar coletivamente o programa de pós-graduação em Supervisão e Currículo da PUC-SP, propõe um novo paradigma - a avaliação emancipatória - que "caracteriza-se como um processo de descrição, análise e crítica de uma dada realidade, visando transformá-la (...). O compromisso principal desta avaliação é o de fazer com que as pessoas direta ou indiretamente envolvidas em uma ação educacional escrevam a sua 'própria história' e gerem as suas próprias alternativas de ação". Sua construção está inspirada em três vertentes teórico-metodológicas: a primeira delas caracteriza-se como avaliação democrática; a segunda é a crítica institucional e criação coletiva; e a terceira a pesquisa participante.

Segundo MINAYO (1997) a ABRASCO "vem empreendendo um esforço sistemático para proceder à avaliação da Pós-Graduação em Saúde Coletiva, atendendo a uma demanda dos professores e pesquisadores que atuam no setor". Este trabalho vem sendo desenvolvido desde 1978, com o I Encontro Nacional de Pós-Graduação em Saúde Coletiva (um ano antes da criação formal da ABRASCO); em 1982, com o II Encontro Nacional; e em 1987, quando houve um trabalho de caracterização dos programas, num seminário em Salvador/Bahia, registrado e publicado por COHN e NUNES (1988). "A Associação tem se preocupado em manter discussões e estabelecer consenso sobre esse nível de ensino da área, inclusive através de oficinas nos vários Congressos que realiza". Porém só em 1995/1996 se conseguiu consolidar um conhecimento mais sistemático abrangendo uma pesquisa nacional descritiva sobre as estruturas curriculares, a demanda, os egressos, a produção e a divulgação científica. Essa investigação, organizada por um grupo de professores/pesquisadores da área, foi objeto de análise em vários seminários, onde estiveram presentes os coordenadores dos cursos, culminando com uma sessão internacional em 1996, quando se debateu, com consultores do país e do exterior, as necessárias mudanças nos rumos dos programas. Os 
resultados desse trabalho foram publicados no final de 1997 na recém-criada revista Ciência \& Saúde Coletiva, da ABRASCO.

A avaliação de um curso nos remete naturalmente à análise da própria instituição de ensino. Segundo BALZAN e DIAS SOBRINHO (1995) "no interior das universidades públicas, não sem contradições, desenvolveu-se a idéia de que a avaliação era necessária ao menos por dois motivos principais: cumprimento do princípio de transparência, ou seja, a exigência ética da prestação de contas à sociedade; e mecanismos de fortalecimento da instituição pública ante contínuas ameaças de privatização. A avaliação institucional ganha força estreitamente ligada à crise da Universidade, cujo caráter público é cada vez mais ameaçado, principalmente porque ela não consegue responder satisfatoriamente ao grande leque diversificado e contraditório de demandas externas".

Para esses autores "a Universidade é uma instituição pluralista e multidimensional que se constrói nos movimentos das relações de forças. Para compreendê-la, é necessário buscar o entendimento das redes 'de significações' múltiplas e o "conjunto de processos e relações que se produzem em seu cotidiano".

A Faculdade tem participado das oficinas da ABRASCO, porém não podemos dizer que existe um envolvimento do conjunto de docentes da Faculdade nessas discussões.

Preocupada com a mudança de perfil dos alunos e com a estrutura do Curso de Especialização em Saúde Pública, a Comissão de Coordenação dos Cursos de Especialização/CPG/FSP realizou, em 1993, uma série de "Encontros Reflexivos sobre Avaliação Institucional e Processo Educativo na FSP”. Novas resoluções da USP18, quanto aos cursos lato sensu e stricto sensu, avaliações departamentais, e avaliações da CAPES reforçam a necessidade e a importância de se repensar e discutir a formação de profissionais em nível de pós-graduação na FSP. Em outubro de 1997, a CPG promoveu seminário com participação de alunos e professores com a seguinte pauta: quem queremos formar no mestrado e doutorado; inserção do aluno nas atividades de pós-graduação, ensino e pesquisa; linhas de pesquisa, produção discente, docentes e disciplinas de pós-graduação. Percebe-se

18 Resolução COPGr-4196, de 6-9-95 
"um certo movimento interno" para discussão e revisão da pós-graduação.

Por outro lado, novos enfoques e novas perspectivas estão surgindo na política de pós-graduação no Brasil, especialmente em relação ao mestrado. Em outubro de 1995 a CAPES definiu nova regulamentação dos cursos de pósgraduação com a instituição do programa Capacitação Profissional Avançada Mestrado Profissionalizante ${ }^{19}$, voltado mais diretamente às necessidades do mercado de trabalho, visando à formação de profissionais com perfis de especialização distintos dos tradicionais, muitas vezes em resposta direta às demandas de agências e empresas interessadas na qualificação de seus quadros. Esta decisão é ainda polêmica, existindo a preocupação de que ameace o futuro desse nível de curso, comprometendo o desenvolvimento da pesquisa no país, conforme manifestação do Professor Antônio J. Severino em entrevista ao Jornal da USP (JORNAL USP, 1996) ; outra crítica se prende ao caráter privatizante da proposta.

Na Universidade de São Paulo, a Pró-Reitoria de Pós-Graduação, em 1997, solicitou encaminhamento de propostas, com vistas à consolidação desse programa, a três de suas unidades - Faculdade de Economia e Administração (FEA), Escola Politécnica (EP), e FSP. O grupo designado pela CPG para estudar esse assunto aponta a necessidade de ampla discussão da proposta, no âmbito da pós-graduação da FSP; considera que todos os cursos de pós são profissionalizantes, uma vez que a finalidade da pós é a formação profissional, quer seja do docente ou do pesquisador; questiona o tipo de apoio financeiro que será fornecido a um curso que não tem impacto imediato no setor produtivo como seria o da FEA e o da EP. Considerando que desde sua origem a FSP já trabalha em sua estrutura curricular na perspectiva da inter ou transdisciplinaridade, concepção que vem aparecendo como novidade nos sistemas de pós-graduação, pergunta: "como poderíamos explorar mais esta nossa vantagem em relação à revisão dos nossos cursos de Pós-Graduação?". Sugere, enfim, a formação de grupos de trabalho para análise e elaboração de propostas, sobre as diversas modalidades de cursos, já oferecidas e não oferecidas, pela FSP, analisando a adequação ou não à nossa

19 ver: documento aprovado pelo Conselho Superior da CAPES. Portaria ํo 47, de 17/10/95, que determinou a implantação de procedimentos apropriados à recomendação, acompanhamento e avaliação desses cursos (Jornal da Ciência Hoje (encarte): 4 - 5, 1996) 
realidade e formação institucional 20 .

Podemos afirmar a partir da nossa vivência na FSP que as opiniões dos professores se dividem em relação a essa adequação. Além dos aspectos apontados pelo grupo de trabalho, alguns professores consideram que o mestrado profissionalizante eqüivaleria ao nosso Curso de Especialização em Saúde Pública e seria uma "pós-graduação de segunda classe" e outros recebem a proposta de forma positiva como resposta às nossas características de curso nesse nível. A FSP parece se constituir de um espaço privilegiado para a discussão sobre o mestrado profissionalizante.

Retornando à especificidade do nosso objeto, entendemos como indicado por PONCE (1994) que a missão da FSP pressupõe pelo menos duas ciências: as ligadas à saúde e as ligadas ao ato de ensinar a saúde. Durante os encontros reflexivos sobre avaliação institucional e processo educativo na FSP, citados anteriormente, uma questão abordada por Ponce foi a da peculiaridade do trabalho da FSP, como unidade de ensino. Concordamos com essa autora quando ela traz para a reflexão da FSP os significados da expressão qualidade - o da sua origem latina significando "peculiaridade", "característica distintiva" e o do senso comum que contém em si mesmo um valor, sendo compreendida como "de boa qualidade".

Neste trabalho estaremos buscando contribuir para a discussão do ensino desenvolvido pela FSP, e para o repensar do processo educativo em saúde pública.

Para analisar a Pós-Graduação em Saúde Coletiva, no âmbito da PósGraduação brasileira, MINAYO (1997) estabeleceu quatro hipóteses como guia de trabalho; destacamos, neste momento, a primeira: "a Pós-Graduação em Saúde Coletiva usufrui dos méritos e dos problemas assinalados para o programa de PósGraduação nacional. No entanto, ao lado do reconhecimento desse lugar na universalidade, há na área uma especificidade caracterizada pela inexistência de formação graduada e por ser um espaço de conhecimento pós-graduado, interdisciplinar e multiprofissional; bem como uma área de articulação intrínseca com as políticas públicas e as práticas dos serviços".

20 BARATA JM, SCHIESRI LNC, VASCONCELLOS MPC, JAIME PC. Algumas considerações sobre à pós-graduação brasileira e a introdução da modalidade 'Capacitação Profissional Avançada' (Mestrado Profissionalizante) na FSP São Paulo; 1997 [Texto de apoio] 
O balanço crítico da pós-graduação da FSP a partir das avaliações da CAPES, da nossa vivência como docente e aluna da Faculdade e dos levantamentos realizados preliminarmente por nós e que serão apresentados no próximo capítulo; sugerem a necessidade de aprofundar a compreensão desses cursos buscando suas peculiaridades. Deste contexto colocam-se algumas questões de base:

Como ocorre a pós-graduação stricto sensu em uma Escola:

- que tradicionalmente está voltada à formação de profissionais para os serviços públicos de saúde?

- que tem priorizado atividades de extensão e ensino voltadas para aplicação de conhecimentos que surgem da necessidade de intervenção no campo da saúde pública?

- que parece guardar pouca relação entre a pesquisa e as atividades de ensino e extensão?

- que se percebe com características muito peculiares e talvez distintas daquelas esperadas pelo principal órgão avaliador e de fomento da pós-graduação no País?

Ressaltamos que as avaliações e os dados disponíveis sobre a pósgraduação contemplam, como criticado anteriormente, não só para a FSP, informações quantitativas e relativas à produtividade do curso e não ao seu processo ou mesmo produto.

Para compreender as peculiaridades da pós-graduação stricto sensu na Faculdade procuramos, ao sistematizar os dados, refletir sobre a dinâmica dos cursos a partir da voz de seus sujeitos - alunos e professores.

Para o alcance desse objetivo partimos de algumas questões norteadoras:

- quem faz a pós-graduação?

- para que se faz a pós-graduação?

- como se faz a pós-graduação na FSP?

- para quem se faz a pós-graduação? 


\section{O PROCESSO DE CONSTRUÇÃO DA PESQUISA}

\subsection{OBJETIVOS}

- analisar e interpretar como vem ocorrendo o processo de formação stricto sensu em saúde pública na FSP;

- analisar como alunos e professores da FSP representam a pós-graduação stricto sensu em saúde pública.

\subsection{PROCEDIMENTOS METODOLÓGICOS}

Pesquisadores que atuam na área de avaliação educacional têm se preocupado em discutir e aprofundar a abordagem qualitativa. Para LUDKE e ANDRÉ (1986) poucos fenômenos educacionais podem ser submetidos apenas à abordagem analítica quantitativa. "Em educação as coisas acontecem de maneira tão inextrincável que fica difícil isolar claramente quais são as responsáveis por determinados efeitos".

Segundo MINAYO (1993) "a abordagem qualitativa permite aprofundamento ou apreensão do mundo dos significados das ações e relações humanas, um lado não perceptível e não captável em equações, médias e estatísticas". Porém, os dados quantitativos e qualitativos não se opõem. Ao contrário se complementam, pois a realidade abrangida por eles interage dinamicamente, excluindo qualquer dicotomia.

Esta pesquisa constituiu-se em um estudo de caso, cujo caminho metodológico buscou compreender os cursos de mestrado e doutorado da FSP, mediante a consideração das interpretações e aspirações daqueles que neles atuam. Por isto, foram privilegiadas as vozes dos alunos e professores procurandose categorias que possibilitaram compor o sujeito informante do estudo.

O delineamento desse caminho procurou ser flexível permitindo um "enfoque progressivo" em áreas particulares que se evidenciam como mais 
significativas no curso da investigação, conforme ressaltado por Gomez, citado por SAUL (1994).

Os procedimentos metodológicos para a coleta de informações, em resumo, estão baseados em: depoimentos de alunos e professores, análise de documentos referentes à pós-graduação stricto sensu da FSP, e levantamentos de dados sobre os cursos da FSP efetuados pela pesquisadora a partir de documentos da Seção de Pós-Graduação (SPG).

Esta divisão está sendo apresentada com a preocupação de deixar mais claro ao leitor e de forma didática os procedimentos utilizados, porém podemos afirmar que a procura pelas diferentes fontes de informação, bem como a análise do tema foram desenvolvidas de tal maneira que uma conduzia a outra, havendo a retroalimentação necessária ao estudo de um fenômeno social (TRIVINÕS, 1987).

\section{Procedimentos para coleta e análise dos depoimentos}

A coleta de depoimentos de alunos e professores dos cursos foi feita através de entrevistas semi-estruturadas, como compreendida por TRIVIÑOS (1987) partindo-se dos questionamentos básicos da pesquisa, com "o informante seguindo espontaneamente a linha de seu pensamento e de suas experiências dentro do foco principal colocado pelo investigador".

As entrevistas seguiram os roteiros em anexo (Anexos 3 e 4 ) e foram realizadas no período de novembro de 1996 a outubro de 1997, pela própria pesquisadora e gravadas em fita magnética com autorização verbal dos depoentes. Tiveram em média a duração de uma hora e trinta minutos, e ocorreram na maioria das vezes em salas de aula ou de reuniões da FSP, especialmente reservadas para isto. Em dois casos a pesquisadora foi até o local de trabalho do aluno e em um até a sua residência.

Os alunos e os professores serão identificados no decorrer do nosso trabalho, não pelo nome, mas por um número seguido pela letra "P" (professores) e pela letra "A" (alunos).

Os depoimentos foram colhidos de alunos que estavam freqüentando regularmente os cursos no período em que se realizou o trabalho de campo deste 
estudo. O critério de escolha dos alunos para a entrevista esteve na dependência das finalidades de cursos de pós-graduação, ou seja procurou-se entrevistar tanto alunos que profissionalmente exercem atividades no magistério superior como os que compõem os quadros de instituições prestadoras de serviços de saúde pública ou de áreas afins. Para identificar alunos "críticos" que formassem um grupo possível de pessoas a serem entrevistadas, a pesquisadora baseou-se em sua vivência como aluna e professora da FSP, na indicação de outros professores e alunos, e na consulta à listagem de alunos segundo profissão e orientador, o que permitiu a identificação de um grupo de aproximadamente 80 alunos.

Foram então consultadas as pastas desses alunos, para identificar: fase do curso em que o aluno se encontrava; nome do orientador; área de concentração; tema da pesquisa; profissão; experiência profissional; realização de cursos anteriores - residência, especialização, mestrado; sexo; idade; e procedência. Desta forma procurou-se, na escolha dos entrevistados, respeitar a diversidade própria dos alunos da FSP no que diz respeito a essas características.

Dez alunos foram selecionados e entrevistados, não havendo nenhuma recusa, ao contrário atendimento imediato e interesse pelo tema, valorizando a proposta desta pesquisa. As entrevistas transcorreram em clima agradável, com os alunos na maioria das entrevistas se empolgando ao relatar sua trajetória, manifestando suas satisfações, decepções e angústias com o curso, e em dois casos chegando a se emocionar por estarem tendo a oportunidade de serem ouvidos. A pesquisadora se percebeu vista pelos alunos como uma "porta voz".

Dos alunos entrevistados, dois são professores universitários, um além de docente atua em secretarias de saúde municipal, dois trabalham em instituição de pesquisa, um na Fundação SEADE, um na CETESB, um em uma creche municipal e por fim uma aluna que, desempregada na época da entrevista, recebia bolsa para cursar a pós-graduação.

As áreas de concentração, nível de curso, e data de início do curso, idade, sexo e curso de graduação estão resumidas no Quadro 2. 
Quadro 2 - Caracterização dos Alunos entrevistados, 1997.

\begin{tabular}{|c|c|c|c|c|c|}
\hline Área conc. & Nível & Início & Idade & Sexo & Graduação \\
\hline EPI & D & 1996 & 43 & M & Estatística \\
\hline EPI & M & 1996 & 34 & $\mathrm{~F}$ & Medicina \\
\hline EPI & M & 1996 & 41 & F & Enfermagem \\
\hline NUT & D & 1994 & 30 & $\mathrm{~F}$ & Nutrição \\
\hline NUT & M & 1996 & 26 & $\mathrm{~F}$ & Nutrição \\
\hline SA & M & 1995 & 45 & M & Engenharia civil \\
\hline SMI & M & 1995 & 34 & F & Ciências Sociais \\
\hline SSP & D & 1993 & 42 & M & Odontologia \\
\hline SSP & D & 1993 & 49 & $\mathrm{~F}$ & Med. Veterinária \\
\hline SSP & M & 1993 & 46 & $\mathrm{~F}$ & Medicina \\
\hline
\end{tabular}

Cinco entrevistados são residentes em São Paulo-SP, um em CampinasSP, um em Salvador-BA, um no Rio de Janeiro-RJ, um em Goiânia-GO e uma na América Central.

Quanto à fase do Curso, três já haviam feito exame de qualificação, um estava elaborando projeto de pesquisa e quatro cumprindo créditos disciplinares, na etapa da entrevista.

Quanto ao local de formação na graduação, os entrevistados procedem de escolas públicas: UNICAMP, UNIFESP, UERJ, UFGO, EESC/USP, UFPR, UFBA e UnB.

Posteriormente à graduação a formação dos alunos abrangeu a realização de residência médica na FM/USP; residência em nutrição HC FM USP; residência em saúde pública e mestrado na ENSP; curso de especialização em saúde pública na ENSP; curso de especialização em saúde pública, curso "curto", curso de especialização em engenharia e saúde ambiental e mestrado na FSP; mestrado em saúde comunitária na UFBA; e mestrado em demografia no CEDEPLAR/UFMG. 
$\mathrm{Na}$ escolha dos professores para entrevista procurou-se, também, respeitar a diversidade do corpo de orientadores dos cursos quanto a sexo, formação na graduação, departamento da FSP a que pertence, há quanto tempo se dedica à atividade de orientação; forma de envolvimento com atividades de ensino, pesquisa e extensão universitária; e disciplinas que ministra. Envolvendo também aqueles que tem assento na $\mathrm{CPG} / \mathrm{FSP}^{21}$ e portanto interferem mais diretamente na política de pós-graduação da FSP e os que influenciam essa política com sua participação nas atividades departamentais.

A seleção do grupo foi feita pela pesquisadora no decorrer das entrevistas, baseada em seu conhecimento pessoal do corpo docente da Faculdade de Saúde Pública e nas questões levantadas durante as entrevistas que provocaram repensar o grupo selecionado inicialmente. Apenas um dos entrevistados era orientando de um aluno também entrevistado.

Não foram selecionados orientadores aposentados bem como os externos à FSP que não participam plenamente do cotidiano da Instituição; pois apesar de corresponderem a $46,6 \%$ do quadro (respectivamente 19,3 e $27,3 \%$ ) e conduzirem atividades de orientação eles não tem assento nos órgãos colegiados da Faculdade.

O número de entrevistas realizadas foi de oito, não havendo também nenhuma recusa. As entrevistas transcorreram em clima tranqüilo, havendo porém pequenas interrupções em três casos quando o espaço utilizado para entrevista foi a sala de reuniões do departamento do docente.

Devido a problemas com o gravador, a entrevista com um professor teve uma fita não gravada, o que justificou um novo momento de entrevista onde se procurou retomar e dar continuidade ao depoimento. Neste caso o professor também se dispôs prontamente a colaborar outra vez.

Dentre os professores entrevistados três iniciaram atividade de orientação entre 1970 e 1974; três entre 1985 e 1989 e dois entre 1994 e 1995. Apenas dois ministram disciplinas obrigatórias. São orientadores ligados as diferentes áreas de

21 Segundo o Regimento da FSP (Resolução 4052 de 22 de novembro de 1993), a CPG é composta por um representante docente de cada Departamento, possuidor no mínimo do título de Doutor e orientador de pós-graduação da FSP. 
concentração do curso, dois de Serviços de Saúde Pública (SSP), dois da Saúde Ambiental (SA), dois da Epidemiologia (EPI), um da Nutrição (NUT) e um da Saúde Materno-Infantil (SMI). Três docentes na época da entrevista pertenciam à CPG.

A idade dos entrevistados variou entre 43 e aproximadamente 60 anos, seis eram do sexo masculino e dois do feminino.

Quanto à formação na graduação três eram médicos, dois farmacêuticosbioquímicos, uma enfermeira, um cientista social e um engenheiro. A qualificação em nível de doutoramento ocorreu para cinco deles na FSP, um na UNICAMP, um na FM/USP e um fora do Brasil.

A experiência profissional prévia ao ingresso na FSP, foi para os seis que cumprem regime de trabalho de dedicação integral à docência e à pesquisa, relacionadas principalmente a serviços de saúde pública em diferentes cargos na SESSP e no Ministério da Saúde, aparece também o serviço privado de saúde. Apenas dois haviam sido professores em universidade pública em cursos de graduação, e um professor de "cursinho pré-vestibular". Um professor atuou também em instituto de pesquisa.

Os dois entrevistados que não trabalhavam em tempo integral na FSP, atuavam concomitantemente em laboratório privado e o outro em uma empresa estatal.

Enquanto os alunos relatam sua trajetória como solicitado pela pesquisadora, já os professores se reportam mais às observações gerais sobre o curso do que ao detalhamento de sua participação no curso, a entrevistadora se percebeu tratada pelos professores como colega da Faculdade, eles também valorizavam o tema da pesquisa mostrando interesse e disponibilidade.

O trabalho de interpretação dos discursos seguiu os passos descritos por SPINK (1995): transcrição literal dos depoimentos, que foi realizada por pessoa especializada e estranha ao ambiente da FSP; leitura flutuante do material, intercalando a escuta do material gravado com a leitura do material transcrito; identificação dos aspectos mais gerais da construção do discurso; mapeamento dos discursos a partir dos temas emergentes definidos pela leitura flutuante e guiados 
pelos objetivos do pesquisador.

Inicialmente as falas de alunos e professores foram agrupadas de acordo com o rateio da entrevista. Posteriormente por temas, que demonstrassem sobre "o que" os sujeitos falam ao dar seu depoimento. Foram então identificados os seguintes temas: histórica profissional; desenvolvimento do curso, relação com a FSP e visão sobre vocação e características da FSP. As leituras posteriores conduziram à identificação de eixos temáticos em torno dos quais os depoimentos se articulavam: projeto acadêmico dos alunos, projeto acadêmico dos professores e dinâmica curricular da pós-graduação.

A identificação desses temas conduziram à etapa de levantamento e análise documental, e delinearam a descrição dos resultados e a sua interpretação.

\section{Procedimentos para coleta de informações em documentos}

O outro conjunto de procedimentos metodológicos desta pesquisa corresponde à análise de documentos referentes à pós-graduação: Decretos; Pareceres, Estatutos, Regimentos, Resoluções, Portarias no âmbito da USP; Relatórios, Atas de reuniões da Congregação e da CPG, ofícios departamentais e Catálogos relativos à pós-graduação da FSP.

A partir dos documentados identificados na FSP chegamos aos documentos produzidos pela USP, CAPES e ABRASCO.

Os documentos coletados inicialmente foram sistematizados com vistas à caracterização dos cursos. Posteriormente a busca de mais documentos e a releitura dos mesmos ocorria conforme a necessidade gerada pelos temas identificados na análise dos depoimentos. Os documentos utilizados estão referenciados no texto deste trabalho conforme foram sendo citados.

Optamos por tratar um dos departamentos - o de Prática de Saúde Pública - como indicativo, ou um informante crítico da estrutura da FSP. A escolha deveu-se à abrangência do mesmo, que envolve segundo os levantamentos deste estudo cerca de $33 \%$ dos orientadores, 30\% das disciplinas eletivas e $37 \%$ das obrigatórias; desenvolve ainda duas áreas de concentração - SSP e AH, e possui cerca de $40 \%$ dos alunos. É também o departamento de origem da pesquisadora, o 
que permite maior observação de seu cotidiano.

Entre os documentos incluem-se também os diversos relatórios produzidos pela Seção de Alunos de Pós-Graduação e que trazem informações quantitativas dos cursos, que contribuíram principalmente para a caracterização do corpo discente. Os relatórios são elaborados conforme demanda da CPG, geralmente para responder a uma solicitação externa ou para análise da própria CPG, o que não dá a esse tipo de levantamento regularidade, justificando-se assim a não observância de um macro temporal desse tipo de dado no nosso estudo. Procurou-se porém observar a abrangência do período de 1990 a 1997.

Outros dados considerados importantes por nós não foram encontrados já compilados o que nos conduziu à realização dos levantamentos descritos a seguir.

Para clarear algumas questões surgidas durante as entrevistas e em críticas apontadas nas últimas avaliações da CAPES, foram efetuados pela pesquisadora levantamentos, no primeiro semestre de 1997, a partir de documentos existentes na Seção de Pós-Graduação da FSP.

São dados que não estavam disponíveis de forma consolidada e que poderiam responder a algumas indagações surgidas no processo de estudo do tema.

Estes levantamentos em síntese dizem respeito às instituições com que a FSP se relaciona; ao perfil do corpo de orientadores; e às disciplinas eletivas e obrigatórias dos cursos. Considerando que as mudanças mais significativas na estrutura da pós-graduação na FSP ocorreram em 1990, e como a maior parte do levantamento foi efetuado no primeiro semestre de 1997, o período objeto dos levantamentos foi de 1990 a 1996.

A coleta de informações sobre a pós-graduação da FSP apresenta uma série de dificuldades como já havia sido identificado no levantamento realizado por nós em 1995 (MARTINS e VASCONCELLOS, 1996), com o objetivo de traçar o perfil da Pós-Graduação na FSP. Essas dificuldades dizem respeito principalmente à forma de arquivamento e registro de informação utilizada pela SPG. Não encontramos, até o $1^{\circ}$ semestre de 1998, fontes que sintetizassem informações 
sobre alunos e professores, e ao procurar as diferentes fontes nem sempre os resultados obtidos eram coincidentes entre si.

Julgamos oportuno apresentar as dificuldades encontradas e salientar a importância da apresentação dos dados que permitiram caracterizar a pósgraduação da FSP de maneira abrangente, e que a nosso ver não são de domínio do grupo de docentes da FSP

O volume de trabalho e de recursos dessa Seção foi ampliado nos últimos anos não só pelo aumento no número de alunos mas também pelos cursos subordinados à mesma; além dessa mudança, a Seção viveu uma fase de transição passando por um período de convivência entre registros manuais e eletrônicos. As pastas dos alunos são volumosas, uma vez que cópia de todo tipo de correspondência relativa ao aluno é aí arquivada. A tentativa de trabalhar com essas pastas no estudo citado mostrou a dificuldade de manuseio das mesmas, o que pode ter gerado problemas quando se deu a passagem de dados para o sistema eletrônico. Não existe, por exemplo, nas pastas, uma ficha síntese do histórico escolar do aluno.

O sistema de controle das atividades de rotina da administração acadêmica Quiron/USP, foi implantado na USP durante o processo de informatização da Universidade iniciado em 1986 (WOLYNEC e MARIN, 1988). Antes dessa época a FSP tinha um número de alunos bem menor que o atual e provavelmente conseguiu manter o controle dos dados sem maiores dificuldades; convém lembrar, também, que nesse período houve relativa instabilidade de composição da equipe de funcionários. Ao passar as informações para o Sistema Quiron, a FSP teve que se adaptar a um sistema padronizado para a Universidade, encontrando muitas vezes dificuldades para adaptar suas necessidades e características a esse padrão. Como exemplo, só poderiam ser registradas no Quiron as disciplinas sigladas, sendo assim, disciplinas realizadas fora da USP não poderiam ser anotadas no Sistema, ficando o Histórico Escolar do aluno incompleto. Muitos campos não foram na época preenchidos ou o foram com dados que a própria responsável pela Seção de Alunos declarou considerar a possibilidade de serem incorretos. Esta situação tem levado a uma constante preocupação e busca de solução através de "mutirões" para atualização e correção dos registros. 
Sem resolver esses problemas apontados, o Quiron foi substituído pelo Sistema Fênix, em setembro de 1996, exigindo ainda mais adaptações, atualizações e correções. Após 15 dias de uso houve um "travamento" do sistema com reinício apenas em janeiro de 1997, acumulando assim grande quantidade de registros a serem feitos. Como o levantamento realizado por nós ocorreu no primeiro semestre de 1997, não pudemos lançar mão exclusivamente do Sistema Fênix. Optamos, portanto, por trabalhar com diferentes fontes conforme a informação desejada. Mantivemos porém apenas uma única fonte para cada tipo de informação procurada, considerando a fidedignidade e viabilidade da coleta de dados. Em nenhum caso buscamos dados nas pastas dos alunos, que são volumosas e de difícil manuseio e que, por experiência de pesquisa anterior, encerra grande possibilidade de erro. Foi dada preferência a fontes que aparecem externamente, ou seja, as que comunicam as atividades do curso junto a alunos, professores, à universidade e às agências de fomento de pesquisa.

Nessas condições foram realizados os três levantamentos descritos a seguir:

- Com o objetivo de identificar com quais instituições a FSP se relaciona e mostrar com que áreas de conhecimento se aproxima, foram identificadas as instituições de origem dos membros das comissões julgadoras de exames de qualificação e defesas de mestrado e doutorado da FSP. Como fonte de dados desse levantamento foram utilizadas as pastas de arquivo dos comunicados de exames de qualificação e defesas que são afixados nos diversos quadros de avisos da FSP na ocasião de sua ocorrência. Devido ao sistema de arquivamento da Seção de Pós-Graduação/FSP, foi possível localizar todos os comunicados de defesas do período, porém quanto aos exames de qualificação não havia registro, nessa fonte, referente aos anos de 1990 a 1993. Um dos problemas encontrados no levantamento foi a incorreção das informações sobre nome das instituições (Ex: um mesmo professor tem cada vez o nome de seu departamento registrado de forma diferente). Essas informações foram corrigidas pela pesquisadora após consulta à catálogos e à página da Internet da escola de origem de cada professor. As instituições foram 
agrupadas por área de conhecimento adotando-se a classificação da CAPES/CNPq (Anexo 7).

- Com o objetivo de identificar os orientadores credenciados pela Comissão de Pós Graduação da FSP segundo vínculo empregatício e área de concentração em que orientam, tempo e local de doutoramento, e tempo de credenciamento, foi utlizado o Sistema Fênix, complementando-se os dados com os processos de credenciamento dos orientadores, e informações da Seção de Pessoal/FSP quanto às datas de aposentadoria dos docentes.

- Os quadros referentes às disciplinas de pós graduação, foram obtidos nas grades horárias entregues aos alunos anualmente com 0 objetivo de descrever as que são regularmente oferecidas e não oferecidas; sua distribuição na grade horária, pré requisitos e número de créditos. Neste caso, julgamos oportuno trabalhar com as grades horárias de 1990 a 1998, e não 1996 como os demais dados quantitativos deste estudo devendo-se isso ao fácil acesso à fonte e à época em que se encerrou o levantamento. 


\section{Capítulo II - CARACTERIZANDO O CORPO DISCENTE E DOCENTE}

A pós-graduação stricto sensu, na FSP, tem o objetivo de preparar pessoal em dois níveis - mestrado e doutorado - para o exercício de atividades de pesquisa e de magistério superior, bem como qualificar pessoal de alto nível para os serviços de saúde (USP, 1994).

Atualmente possui seis áreas de concentração22: Epidemiologia (EPI), Nutrição (NUT), Saúde Ambiental (SA), Saúde Materno-Infantil (SMI), Serviços de Saúde Pública (SSP), e Administração Hospitalar (AH), correspondendo grosso modo aos departamentos existentes na FSP. Apenas o Departamento de Prática de Saúde Pública possui duas áreas - Serviços de Saúde Pública e Administração Hospitalar. Com exceção da SMI as outras áreas foram criadas em 1970, quando os cursos tiveram início, e a SMI, antes pertencente a SSP, foi criada em 1992.

Em quase trinta anos de existência, passou por reformulações pontuais em sua estrutura, principalmente no que diz respeito aos pré-requisitos para matrícula, ao quadro de disciplinas oferecidas; e ao número de créditos exigidos. A maior reforma curricular ocorreu em 1991 introduzindo no currículo do mestrado disciplinas obrigatórias e retirando um dos pré-requisitos para ingresso no curso - a apresentação do certificado de conclusão de especialização em saúde pública (Anexo 5).

As disciplinas de Pós-Graduação Stricto Sensu da FSP são ministradas de forma indistinta para os cursos de mestrado e de doutorado. No período de 1991 a 1998 o número de disciplinas obrigatórias para o mestrado variou de 5 a 8 disciplinas e o de eletivas para o mestrado e doutorado de 110 a 132 disciplinas.

O prazo global para conclusão do mestrado, até 1995, era de no mínimo um ano e no máximo cinco, e de dois a cinco anos para o doutorado, prazos esses maiores que os recomendados pela CAPES. Foram alterados para no máximo três

22 Por área de concentração entende-se o campo específico de conhecimento que constituirá o objetivo principal dos estudos e atividades de pesquisa do aluno (USP. Regimento Geral, 1990, Artigo $\left.86 \S 1^{\circ}\right)$. 
anos, em 1997, um ano a menos que o permitido pelo regimento da USP. Para o doutorado o prazo estabelecido pela FSP é de dois a quatro anos. É possível, ainda, o trancamento da matrícula por prazo global não superior a um ano, correspondendo à plena cessação das atividades escolares, em qualquer estágio do curso²3.

Segundo Relatório da Seção de Pós-Graduação da FSP (fevereiro de 1995) o tempo médio para conclusão do mestrado variou nos últimos 15 anos de 4,4 a 7,6 anos; e para o doutorado de 4,6 a 6,8 anos. Cohn e Nunes (1988) analisando oito cursos da área de saúde pública, apontaram o longo tempo para titulação dos pós-graduandos como uma característica generalizada de quase todos os programas estudados na época. Ao analisarmos o Oficio CPG/045/96 percebemos que a Comissão de Pós-graduação da FSP aceitando a recomendação da CAPES estabeleceu como principal meta da atual revisão das normas da pós-graduação a redução desse tempo para 3 e 4 anos respectivamente, o que efetivamente ocorreu em 1997, como referido anteriormente. Os prazos médios recomendados pela CAPES para cursos nível A são de 30 meses para mestrado e 36 meses para Doutorado.

Em 1995, iniciou-se em Caxias do Sul uma extensão do curso de mestrado da FSP, junto a um consórcio de escolas da região, com a meta de formar 16 mestres em saúde pública no prazo de 30 meses. No $2^{\circ}$ semestre de 1997 todos os alunos fizeram exame de qualificação mostrando um comportamento diferente do curso regular da FSP. Esta iniciativa está associada a outra proposta CAPES - a do Mestrado Interinstitucional24. O curso é ministrado em Caxias do Sul por professores da FSP e é, em princípio, semelhante ao da FSP. Seria necessário o desenvolvimento de uma avaliação comparativa entre os dois cursos o que certamente trará novos elementos que poderão impulsionar as reflexões sobre a pós-graduação na FSP.

\footnotetext{
23 Resolução 4476, de 17-9-97.

24 ver: CAPES/Coordenadoria de Desenvolvimento Institucional - Subprograma Mestrado Interinstitucional, abril 1996.
} 


\section{CORPO DISCENTE}

Para a apresentação do perfil do corpo discente da Pós-Graduação "Stricto Sensu" decidimos lançar mão de estudo realizado anteriormente por nós, e citado na apresentação deste trabalho. Esse estudo visava compreender melhor a pós-graduação na FSP, e foi motivado por discussões que vinham ocorrendo na época envolvendo a suspensão de especialização em saúde pública da Faculdade. Considerando-se os dados disponíveis, no Sistema Quiron/USP25, em junho de 1996, esse levantamento restringiu-se à análise das variáveis: curso, sexo, idade, estado civil, ano de ingresso no curso e área de concentração; abrangendo o período de 1973 a 1995 (MARTINS e VASCONCELLOS 1996) .

No período referido a FSP apresentou um número significativo de alunos perfazendo um total de 1195 ingressantes, com diferentes formações básicas, sendo 818 para o mestrado e 377 para o doutorado (MARTINS e VASCONCELLOS 1996) (Gráfico 1).

\section{Gráfico 1 - Alunos de Mestrado e Doutorado/FSP, segundo curso 1973-1995}

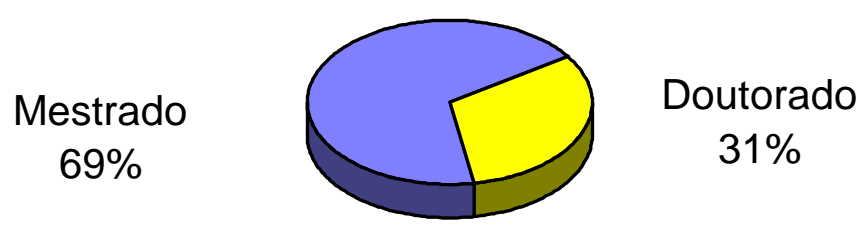

Fonte: Departamento de Informática da Reitoria/USP-Agosto95. In:Martins CL e Vasconcellos MP, 1996

Provavelmente é a escola, no Brasil, que mais formou alunos nesse nível de curso. Segundo TANAKA (1997) a FSP teve 35\% da demanda por mestrado em saúde pública, em 1996, em todo país. Foi a escola com maior número de inscritos para seleção, sendo também a que tem o maior número de vagas. Em 1990, as vagas para o mestrado foram estabelecidas em 50 , e para o doutorado o número esteve na dependência de existência de disponibilidade de vagas de orientadores, a na USP na época deste estudo. Foi substituído pelo Sistema Fênix em 1997. 
partir de 1997 também as vagas de mestrado dependem dessa disponibilidade. Talvez devido a essa alteração, a média de ingresso observada na FSP no período de 1994 a 1996, de 57,6 alunos para o mestrado e de 31,8 para o doutorado, tenha aumentado em 1997 e 1998 para 93 no mestrado e reduzido para 23,5 no doutorado (Tabela 1).

Tabela 1 - Candidatos à Pós-Graduação Strictu Sensu FSP/USP

segundo nível do curso e fases do processo seletivo, 1994 a 1998.

\begin{tabular}{|c|c|c|c|c|c|}
\hline Ano & Curso & Inscritos & Aprovados & Selecionados & Matriculados \\
\hline \multirow[t]{3}{*}{1994} & Mestrado & 159 & 110 & 69 & 63 \\
\hline & Doutorado & 39 & 35 & 30 & 38 \\
\hline & Total & 198 & 145 & 99 & 101 \\
\hline \multirow[t]{3}{*}{1995} & Mestrado & 219 & 109 & 70 & 58 \\
\hline & Doutorado & 32 & 18 & 20 & 19 \\
\hline & Total & 251 & 127 & 90 & 77 \\
\hline \multirow[t]{3}{*}{1996} & Mestrado & 271 & 160 & 71 & 71 \\
\hline & Doutorado & 41 & 31 & 45 & 27 \\
\hline & Total & 312 & 191 & 116 & 98 \\
\hline \multirow[t]{3}{*}{1997} & Mestrado & 249 & 191 & 81 & 85 \\
\hline & Doutorado & 41 & 35 & 21 & 20 \\
\hline & Total & 290 & 226 & 102 & 105 \\
\hline \multirow[t]{3}{*}{1998} & Mestrado & 289 & 153 & 97 & 101 \\
\hline & Doutorado & 49 & 29 & 28 & 27 \\
\hline & Total & 338 & 182 & 125 & 128 \\
\hline
\end{tabular}

A seleção dos candidatos ao curso ocorre uma vez ao ano, e desde 1991 envolve uma prova eliminatória de inglês e uma prova escrita para avaliar a capacidade de interpretação, síntese, expressão e análise de texto, elaboradas por instituições contratadas para esse fim.

O segundo momento da seleção corresponde à escolha do orientador, que segue processos e critérios estabelecidos pelos Departamentos de origem do professor.

A procura pelo curso vem aumentando nos últimos anos, sendo que conforme o ano entre 48 e $68 \%$ dos inscritos são reprovados nas provas ou não são 
selecionados nos departamentos provavelmente por falta de vagas. O número de matriculados no mestrado ultrapassou a 70 em 1997 e 1998, quando o limite de vagas (70) deixou de ser estabelecido pela CPG, passando a ser preenchido de acordo com a disponibilidade do orientador (Tabela 1).

As áreas de concentração com maior número de alunos são: Serviços de Saúde Pública (40\% mestrado e 39\% doutorado) e Epidemiologia (28\% mestrado e $26 \%$ doutorado) que correspondem aos departamentos com maior número de professores (Gráficos 2 e 3). Todas as áreas tem proporção maior de mestrandos, variando de 60 a $73 \%$ dos alunos.

Gráfico 2 - Alunos de Mestrado/FSP

segundo Área de Concentração 1973-1995

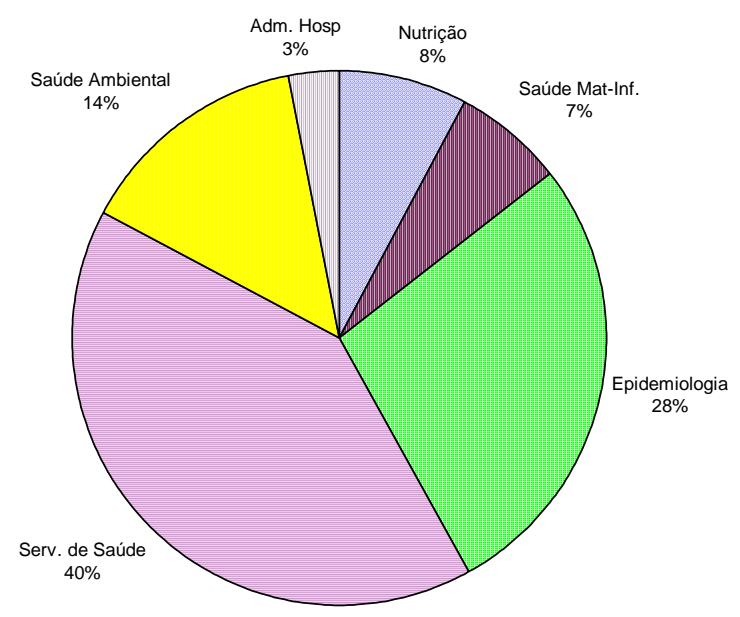

Fonte: Departamento de Informática da Reitoria/USP-Agosto95.

In:Martins CL e Vasconcellos M.P, 1996

Gráfico 3 - Alunos de Doutorado/FSP

segundo Área de Concentração 1973-1995

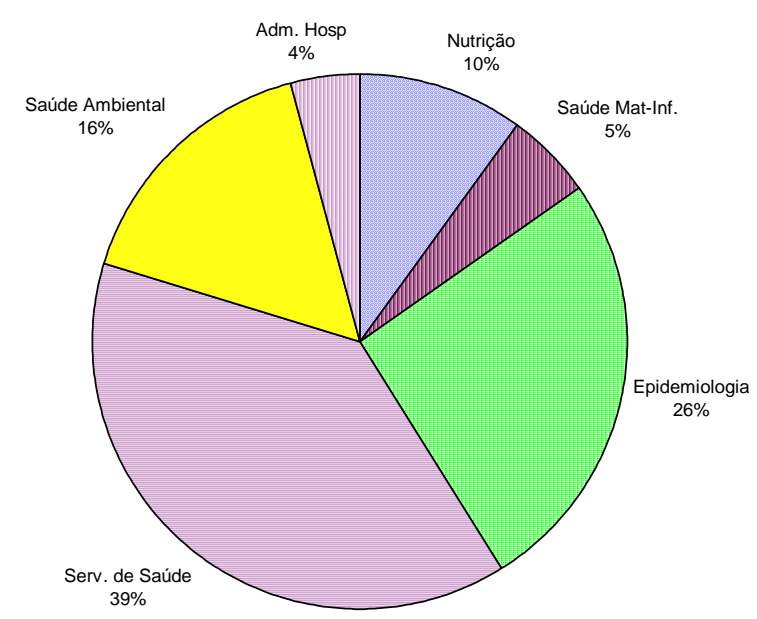


Os alunos são predominantemente do sexo feminino, reforçando a tendência que vem sendo observada nos cursos da área de saúde (Gráfico 4).

\section{Gráfico 4 - Alunos de Mestrado e Doutorado/FSP}

segundo Sexo 1973-1995

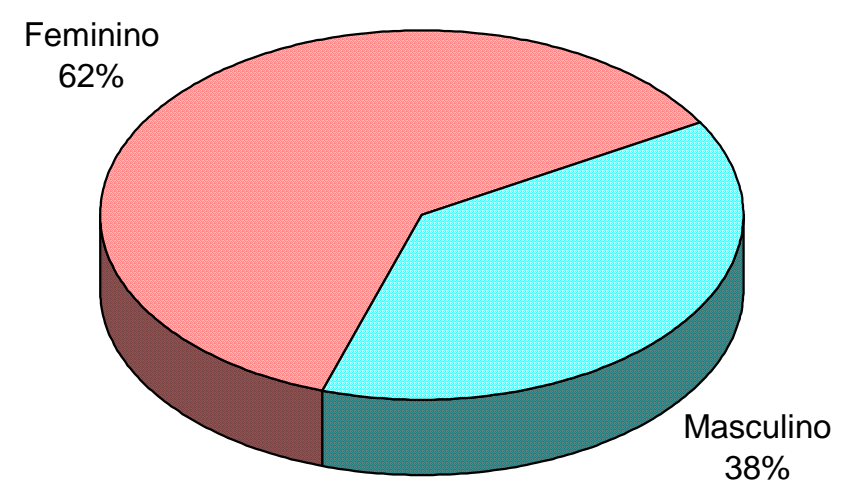

Fonte: Departamento de Informática/CCE/USP-Agosto95.

O Gráfico 4 mostra a distribuição por sexo, segundo área de concentração, indicando para todas as áreas, excetuando-se saúde ambiental, proporção maior de mulheres. No caso da SA, quando separamos por período observamos que de 1990 a 1995, as mulheres compõem 53,3\% do grupo dessa área enquanto no período de 1973 a 1995 essa porcentagem era de 43,2\% (Gráfico 5). 


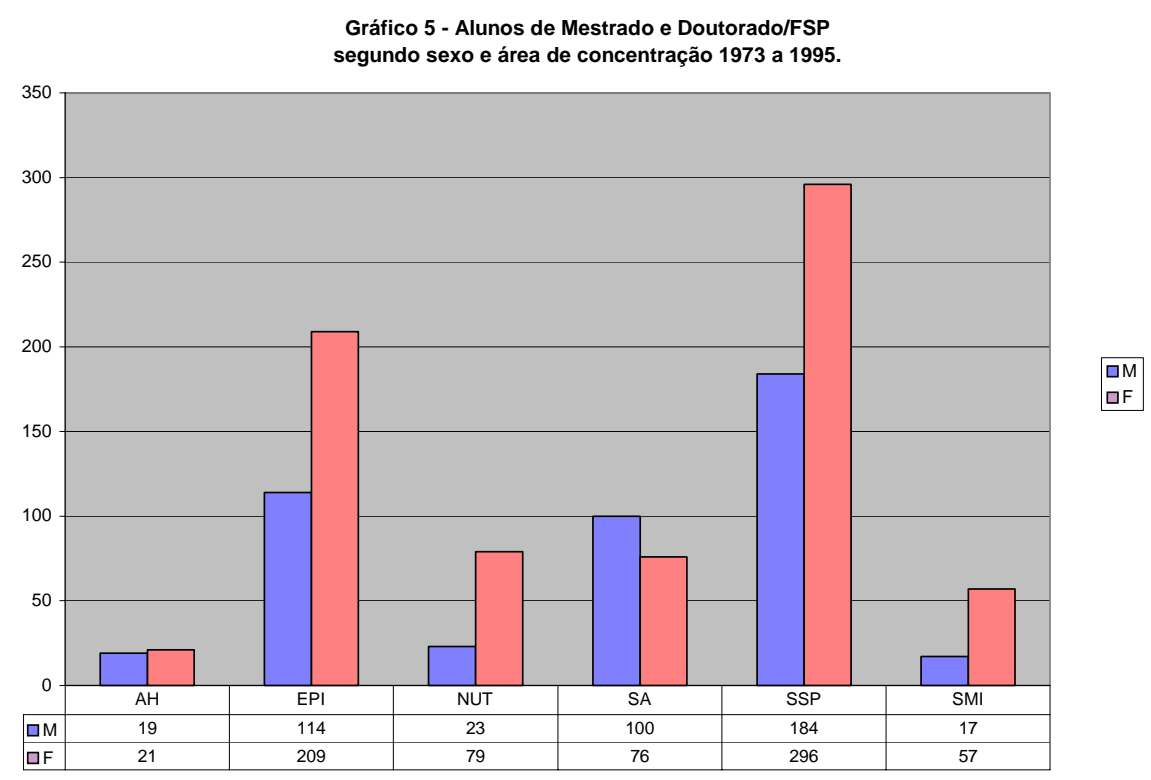

Fonte: Departamento de Informática CCE/USP - Agosto 95

A idade média dos alunos ao ingressar na pós graduação é de 33,7 anos para o mestrado e de 38,5 para o doutorado (Gráfico 6), resultados semelhantes aos encontrados por TANAKA (1997) para os outros cursos da área de saúde coletiva. Esta idade é considerada alta pelas agências de fomento para, por exemplo, a concessão de bolsas. Lembramos que VASCONCELLOS e NARVAI (1997) encontraram para os alunos do Curso de Especialização em Saúde Pública da FSP a média de 33,45 anos de idade.

A idade média dos alunos por área de concentração é semelhante à do grupo geral de alunos. Separando-se os alunos que ingressaram na pós-graduação entre 1990 e 1995, não se observa mudanças na idade média. Quanto à área de concentração, para esse mesmo período, as médias variaram entre 32,59 anos no mestrado para a área SA e 35,89 para AH. No doutorado, entre 36,83 para SA e NUT e 40,41 anos para AH. 
Gráfico 6 - Alunos de Mestrado e Doutorado FSP/USP

segundo Idade Média, curso e ano de ingresso, 1973 a 1995.

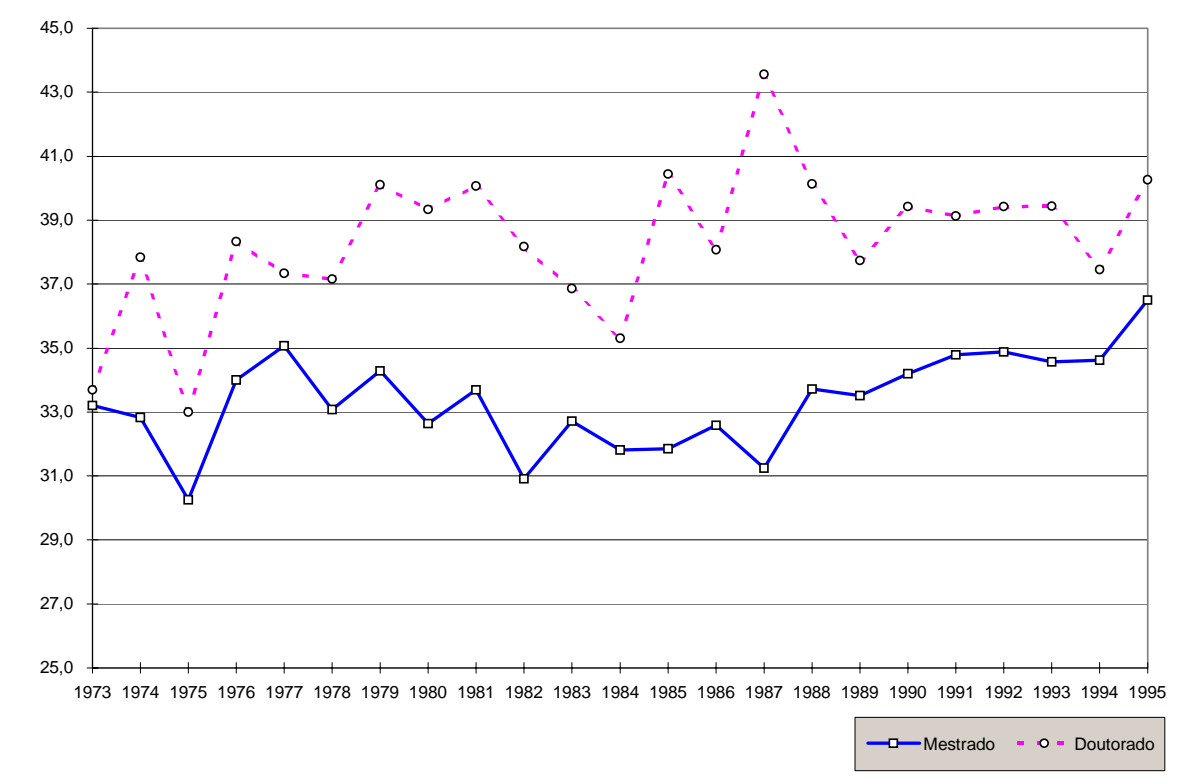

Fonte: Departamento de Informática/CCE/USP-Agosto95.

In:Martins CL e Vasconcellos, MP, 1996

A composição dos alunos em relação à formação na graduação é uma informação que no momento de elaboração deste trabalho não pode ser disponibilizada pelo Sistema de Controle Acadêmico Fênix/USP, mas pode ser indicada pelo trabalho de TANAKA (1997), que estudando o perfil dos candidatos à pós graduação para o ano de 1996, em todos os cursos do país, encontrou para a FSP: $16 \%$ - medicina; $13,2 \%$ - enfermagem; $44,1 \%$ - demais profissionais da área da saúde; $7 \%$ da área de ciências sociais; 7,1\% - engenharia e arquitetura; e 12,7\% outras áreas.

A distribuição dos profissionais nos diferentes cursos do país depende em parte da origem dos cursos, alguns, apesar de multiprofissionais são predominantemente médicos como os da FM/UFPEL $(61,1 \%)$ e da EPM/UNIFESP (57,9\%), muitos não tem engenheiros e arquitetos ou tem pequena porcentagem desses profissionais. O IMS/UERJ tem maior proporção de "demais profissionais da área da saúde" (55\%) com predominância de 46\%, nesse grupo, de psicólogos. Provavelmente o perfil do corpo docente e de linhas de pesquisa existentes determina a procura dos alunos nos casos assinalados. A FSP e a ENSP parecem ser as escolas que possuem a maior variedade de formação dos que procuram a Pós-Graduação. 
Tanaka discutindo este tema no Seminário sobre a Pós-Graduação da FSP, em novembro de 1997, acrescentou a essas informações dados referentes aos inscritos para seleção em 1997, apresentados na Tabela 2, afirmando ser semelhante a distribuição profissional dos candidatos ao mestrado em relação ao doutorado. Encontramos aumento da porcentagem do grupo classificado como "demais profissionais" (de 33,9\% para 42,5\%). Apesar de constituírem porção significativa não dispomos de um detalhamento das profissões desse grupo. A maior procura, no momento, ainda é constituída por profissionais de saúde.

Como indicador de uma possível mudança no perfil profissional dos alunos, consideramos o encontrado na pesquisa de VASCONCELLOS e NARVAI (1997), para o Curso de Especialização em Saúde Pública da FSP onde foi observado, no período de 1985 a 1994, o crescimento do número de pessoas das áreas de ciências humanas e sociais. Podemos concluir que o quadro para a PósGraduação não é estável, apresentando tendências de mudança, que mereceriam ser quantificadas.

Nos depoimentos os professores falam de outras mudanças no perfil dos alunos, que serão comentados no próximo capítulo.

Tabela 2 - Candidatos ao Mestrado e Doutorado FSP/USP segundo formação na graduação, 1996 e 1997.

\begin{tabular}{lcccc}
\hline Graduação & \multicolumn{2}{c}{1996} & \multicolumn{2}{c}{1997} \\
& $\mathrm{n}^{\circ}$ & $\%$ & $\mathrm{n}^{\circ}$ & $\%$ \\
\hline Medicina & 45 & 16,99 & 57 & 16,06 \\
Enfermagem & 37 & 13,97 & 41 & 11,55 \\
Nutrição & 30 & 11,32 & 24 & 6,76 \\
Eng/Arquit & 20 & 7,54 & 36 & 10,14 \\
Sociais & 20 & 7,54 & 13 & 3,66 \\
Odontologia & 13 & 4,90 & 24 & 6,76 \\
Vet/Zoot & 11 & 4,15 & 9 & 2,53 \\
Demais & 89 & 33,59 & 151 & 42,54 \\
\hline TOTAL & $\mathbf{2 6 5}$ & $\mathbf{1 0 0 , 0 0}$ & $\mathbf{3 5 5}$ & $\mathbf{1 0 0 , 0 0}$ \\
\hline
\end{tabular}

In:TANAKA (Seminário FSP, 1997)

Segundo MINAYO (1997) vem aumentando a participação de alunos procedentes de serviços de saúde na pós-graduação em saúde coletiva de todo país. Levantamento da SPG/FSP (Tabelas 3 e 4 ) mostra que no período de 1992 a 
1995, em média $11,37 \%$ dos mestrandos e $31,9 \%$ dos doutorandos são docentes. 0 critério adotado para esse levantamento agrupou os não docentes em servidores públicos e privados, sem especificar o tipo de serviço em que o aluno está inserido, e nos permite confirmar que a grande maioria é de servidores públicos. Os alunos sem vínculo empregatício não ultrapassaram, no período, o valor $15,9 \%$ para o mestrado e $9,4 \%$ para o doutorado.

Tabela 3 - Alunos de Mestrado FSP/USP

segundo vínculo empregatício, 1992 a 1995.

\begin{tabular}{|c|c|c|c|c|c|c|c|c|c|c|}
\hline \multirow[t]{2}{*}{ Ano } & \multicolumn{2}{|c|}{ Docentes } & \multicolumn{2}{|c|}{$\begin{array}{l}\text { Servidores } \\
\text { Públicos }\end{array}$} & \multicolumn{2}{|c|}{$\begin{array}{l}\text { Servidores } \\
\text { Privados }\end{array}$} & \multicolumn{2}{|c|}{ Sem vínculo } & \multicolumn{2}{|c|}{ Total } \\
\hline & $\mathrm{N}^{0}$ & $\%$ & $n^{0}$ & $\%$ & $n^{0}$ & $\%$ & $n^{0}$ & $\%$ & $n^{0}$ & $\%$ \\
\hline 1992 & 05 & 9,6 & 43 & 82,7 & - & - & 04 & 7,7 & 52 & 100,0 \\
\hline 1993 & 08 & 13,3 & 42 & 70,0 & 02 & 3,3 & 08 & 13,3 & 60 & 100,0 \\
\hline 1994 & 09 & 13,0 & 45 & 65,2 & 04 & 5,8 & 11 & 15,9 & 69 & 100,0 \\
\hline 1995 & 06 & 8,8 & 46 & 67,7 & 06 & 8,8 & 10 & 14,7 & 68 & 100,0 \\
\hline
\end{tabular}

Tabela 4 - Alunos de Doutorado FSP/USP

segundo vínculo empregatício, 1992 a 1995.

\begin{tabular}{|c|c|c|c|c|c|c|c|c|c|c|}
\hline \multirow[t]{2}{*}{ Ano } & \multicolumn{2}{|c|}{ Docentes } & \multicolumn{2}{|c|}{$\begin{array}{l}\text { Servidores } \\
\text { Públicos }\end{array}$} & \multicolumn{2}{|c|}{$\begin{array}{l}\text { Servidores } \\
\text { Privados }\end{array}$} & \multicolumn{2}{|c|}{ Sem Vínculo } & \multicolumn{2}{|c|}{ Total } \\
\hline & $n^{0}$ & $\%$ & $n^{0}$ & $\%$ & $n^{\circ}$ & $\%$ & $n^{\circ}$ & $\%$ & $n^{0}$ & $\%$ \\
\hline 1992 & 11 & 35,5 & 19 & 61,3 & - & - & 1 & 3,2 & 31 & 100,0 \\
\hline 1993 & 10 & 38,5 & 13 & 50,0 & 1 & 3,8 & 2 & 7,7 & 26 & 100,0 \\
\hline 1994 & 08 & 25,0 & 20 & 62,5 & 1 & 3,1 & 3 & 9,4 & 32 & 100,0 \\
\hline 1995 & 06 & 28,6 & 12 & 57,1 & 2 & 9,5 & 1 & 4,8 & 21 & 100,0 \\
\hline
\end{tabular}

Estudo sobre os egressos de dez cursos de pós-graduação stricto sensu no Brasil, do período de 1990 a 1994 envolvendo respostas a um questionário de 
$51,5 \%$ dos formados no período, mostra que em sua grande maioria os egressos estavam inseridos no mercado de trabalho, $5 \%$ estavam desempregados ou não responderam à questão referente a local de trabalho. A inserção no mercado de trabalho se deu em universidades públicas $(32,4 \%)$, na qualidade de docentes e pesquisadores; em serviços públicos de saúde $(29,2 \%)$ e em institutos e fundações igualmente públicas $(21,7 \%)$. Estes últimos no exercício de funções técnicoassistenciais e em segundo lugar em funções administrativas. Nessa pesquisa GOLDENBERG e SCHENKMAN (1997), observaram ainda que o trabalho em entidades da sociedade civil chegou a $14,5 \%$ nos egressos que referiram o exercício de atividades profissionais complementares, enquanto como ocupação principal, esse setor apresenta a proporção de $0,9 \%$ dos empregos.

\section{CORPO DOCENTE}

Procuramos traçar o perfil do corpo docente da Pós-Graduação stricto sensu tendo como fonte de informação o Sistema Fênix de Controle Acadêmico/USP e os currículos dos orientadores arquivados na Seção de PósGraduação/FSP. Considerando que esses dados foram coletados no primeiro semestre de 1997, estabelecemos o final de dezembro de 1996 como data de referência para o levantamento.

A FSP, em dezembro de 1996, contava com 144 professores credenciados para orientação na Pós-Graduação stricto sensu. Porém seis desses professores exercem essa atividade em mais de uma área de concentração dos cursos. Para permitir a caracterização por áreas consideramos o total de 150 orientadores. Sendo assim o grupo de orientadores é formado por $80(53,33 \%)$ professores pertencentes ao corpo docente da Faculdade; 41 (27,33\%) externos à FSP, credenciados exclusivamente para atividade de orientação; e 29 (19,33\%) professores aposentados da própria FSP e que continuam a desenvolver atividades de orientação.

Ressaltamos a partir desse quadro o fato de que quase metade dos orientadores não vivenciam o cotidiano da escola apesar de em alguns casos freqüentarem a Faculdade e ministrarem aulas. As áreas de SA e SSP têm mais da 
metade dos orientadores nessa situação. AH e EPI são as áreas com proporção maiores de professores na ativa (Tabela 5).

\section{Tabela 5 - Pós-Graduação stricto sensu FSP/USP}

Orientadores segundo área de concentração e vínculo com a Faculdade, 1996.

\begin{tabular}{|c|c|c|c|c|c|c|c|c|c|c|c|c|c|c|}
\hline \multirow{3}{*}{$\begin{array}{c}\text { VÍNCULO COM } \\
\text { A FSP }\end{array}$} & \multicolumn{12}{|c|}{ ÁREA de CONCENTRAÇÃO } & & \\
\hline & \multicolumn{2}{|c|}{ SSP } & \multicolumn{2}{|c|}{$\mathrm{AH}$} & \multicolumn{2}{|c|}{ EPI } & \multicolumn{2}{|c|}{ SA } & \multicolumn{2}{|c|}{ SMI } & \multicolumn{2}{|c|}{ NUT } & \multicolumn{2}{|c|}{ TOTAL } \\
\hline & $\mathrm{n}^{0}$ & $\%$ & $\mathrm{n}^{0}$ & $\%$ & $\mathrm{n}^{0}$ & $\%$ & $\mathrm{n}^{0}$ & $\%$ & $\mathrm{n}^{0}$ & $\%$ & $\mathrm{n}^{0}$ & $\%$ & $\mathrm{n}^{0}$ & $\%$ \\
\hline APOSENTADO & 13 & 26,0 & 1 & 14,3 & 4 & 11,4 & 4 & 14,3 & 2 & 16,7 & 5 & 27,8 & 29 & 19,3 \\
\hline & 16 & 32 & 1 & 14,3 & 6 & & 13 & 46 & & & 2 & 11 & 41 & 27,3 \\
\hline NA ATIVA & 21 & 42,0 & 5 & 71,4 & 25 & 71,4 & 11 & 39,3 & 7 & 58,3 & 11 & 61,1 & 80 & 53,3 \\
\hline TOTAL & 50 & 100,0 & 7 & 100,0 & 35 & 100,0 & 28 & 100,0 & 12 & 100,0 & 18 & 100,0 & 150 & 100,0 \\
\hline
\end{tabular}

${ }^{*}$ O número de orientadores era de 144 porém 6 orientam em mais de uma área de concentração: 1 aposentado nas áreas SSP e AH; 3 na ativa orientam nas áreas de SSP e AH; 1 aposentado nas de EPI e SSP, e 1 externo na SA e SSP.

Fonte: Seção de Pós-Graduação FSP/USP

Dos 41 orientadores externos, 13 (31,70\%) não pertencem a instituições de ensino superior, exercem suas atividades profissionais nas seguintes instituições: Instituto Dante Pazzanese/SESSP, Instituto Adolfo Lutz/SESSP, Instituto de Saúde/SESSP, Instituto Lauro de Souza Lima/SESSP, IAMSP, Instituto de Pesca, CETESB, FUNDACENTRO, e Instituto de Botânica. Dos 26 procedentes de instituições de ensino superior, 14 são da USP, três da UNESP, dois da UNICAMP, três da UNIFESP, dois da FCM/Santa Casa SP, um da PUC SP e um da UFMG.

A maioria dos orientadores externos, 12 (46\%), vêm de escolas médicas, sendo 5 de departamentos de medicina preventiva. A outra concentração de professores encontra-se na área de farmácia bioquímica (5 orientadores) e veterinária (4 orientadores); enfermagem e odontologia tem cada uma, um orientador externo. Apenas um pertence à área de ciências sociais aplicadas (administração) e um à de ciências humanas (psicologia).

No corpo de orientadores da FSP também se observa a presença de profissionais com diferentes formações na graduação (Tabela 6). A maior proporção $(56,16 \%)$ se concentra na área de ciências da saúde, com predominância da medicina $(32,87 \%$ do total de orientadores). Esta observação também é válida 
quando analisamos separadamente o grupo de professores na ativa, aposentados e externos.

Tabela 6 - Pós Graduação stricto sensu FSP/USP

Orientadores segundo formação na graduação, 1996.

\begin{tabular}{|c|c|c|c|c|c|c|c|c|c|}
\hline \multirow{3}{*}{ Área de conhecimento } & \multirow{3}{*}{ Graduação } & \multicolumn{6}{|c|}{ Vínculo empregatício com a FSP } & \multirow{2}{*}{\multicolumn{2}{|c|}{ TOTAL }} \\
\hline & & \multicolumn{2}{|c|}{ Ativa } & \multicolumn{2}{|c|}{ Externo } & \multicolumn{2}{|c|}{ Aposentado } & & \\
\hline & & $\mathrm{n}^{0}$ & $\%$ & $\mathrm{n}^{0}$ & $\%$ & $\mathrm{n}^{0}$ & $\%$ & $\mathrm{n}^{0}$ & $\%$ \\
\hline \multirow[t]{7}{*}{ C. Saúde } & Medicina & 24 & $30,4 \%$ & 18 & $45,0 \%$ & 6 & $22,2 \%$ & 48 & $32,9 \%$ \\
\hline & Odontologia & 3 & $3,8 \%$ & 1 & $2,5 \%$ & 4 & $14,8 \%$ & 8 & $5,5 \%$ \\
\hline & Farmácia Bioq & 6 & $7,6 \%$ & 2 & $5,0 \%$ & 3 & $11,1 \%$ & 11 & $7,5 \%$ \\
\hline & Enfermagem & 4 & $5,1 \%$ & 1 & $2,5 \%$ & 1 & $3,7 \%$ & 6 & $4,1 \%$ \\
\hline & Nutrição & 6 & $7,6 \%$ & - & - & 2 & $7,4 \%$ & 8 & $5,5 \%$ \\
\hline & Educ Física & 0 & $0,0 \%$ & 1 & $2,5 \%$ & - & - & 1 & $0,7 \%$ \\
\hline & Sub total & 43 & $54,4 \%$ & 23 & $57,5 \%$ & 16 & $59,3 \%$ & 82 & $56,2 \%$ \\
\hline \multirow[t]{4}{*}{ C. Sociais Aplicadas } & Direito & 3 & $3,8 \%$ & - & - & - & - & 3 & $2,1 \%$ \\
\hline & econ domest & 1 & $1,3 \%$ & - & - & - & - & 1 & $0,7 \%$ \\
\hline & S. Social & 1 & $1,3 \%$ & - & - & - & - & 1 & $0,7 \%$ \\
\hline & Sub total & 5 & $6,3 \%$ & - & - & - & - & 5 & $3,4 \%$ \\
\hline \multirow[t]{7}{*}{ C. Humanas } & Filosofia & 0 & $0,0 \%$ & - & - & 1 & $3,7 \%$ & 1 & $0,7 \%$ \\
\hline & C. Sociais & 8 & $10,1 \%$ & 1 & $2,5 \%$ & - & - & 9 & $6,2 \%$ \\
\hline & C. Políticas & 0 & $0,0 \%$ & - & - & 1 & $3,7 \%$ & 1 & $0,7 \%$ \\
\hline & Geografia & 1 & $1,3 \%$ & - & - & - & - & 1 & $0,7 \%$ \\
\hline & Psicologia & 1 & $1,3 \%$ & 2 & $5,0 \%$ & - & - & 3 & $2,1 \%$ \\
\hline & Educação & 1 & $1,3 \%$ & - & - & - & - & 1 & $0,7 \%$ \\
\hline & Sub total & 11 & $13,9 \%$ & 3 & $7,5 \%$ & 2 & $7,4 \%$ & 16 & $11,0 \%$ \\
\hline \multirow[t]{4}{*}{ C. Exatas e da Terra } & Estatística & 2 & $2,5 \%$ & 1 & $2,5 \%$ & - & - & 3 & $2,1 \%$ \\
\hline & Física & 1 & $1,3 \%$ & - & - & - & - & 1 & $0,7 \%$ \\
\hline & Química & 1 & $1,3 \%$ & - & - & 1 & $3,7 \%$ & 2 & $1,4 \%$ \\
\hline & Sub total & 4 & $5,1 \%$ & 1 & $2,5 \%$ & 1 & $3,7 \%$ & 6 & $4,1 \%$ \\
\hline \multirow[t]{2}{*}{ C. Biológicas } & Biologia & 6 & $7,6 \%$ & 5 & $12,5 \%$ & 1 & $3,7 \%$ & 12 & $8,2 \%$ \\
\hline & Sub total & 6 & $7,6 \%$ & 5 & $12,5 \%$ & 1 & $3,7 \%$ & 12 & $8,2 \%$ \\
\hline \multirow[t]{3}{*}{ C. Agrárias } & Med Veterinária & 1 & $1,3 \%$ & 3 & $7,5 \%$ & 3 & $11,1 \%$ & 7 & $4,8 \%$ \\
\hline & Agronomia & 1 & $1,3 \%$ & - & - & - & - & 1 & $0,7 \%$ \\
\hline & Sub total & 2 & $2,5 \%$ & 3 & $7,5 \%$ & 3 & $11,1 \%$ & 8 & $5,5 \%$ \\
\hline \multirow[t]{2}{*}{ Engenharias } & Engenharia & 4 & $5,1 \%$ & - & - & 1 & $3,7 \%$ & 5 & $3,4 \%$ \\
\hline & Sub total & 4 & $5,1 \%$ & - & - & 1 & $3,7 \%$ & 5 & $3,4 \%$ \\
\hline \multirow[t]{2}{*}{ Outros } & educ sanit & 2 & $2,5 \%$ & - & - & 1 & $3,7 \%$ & 3 & $2,1 \%$ \\
\hline & Sub total & 2 & $2,5 \%$ & - & - & 1 & $3,7 \%$ & 3 & $2,1 \%$ \\
\hline \multirow[t]{2}{*}{ s/inf } & s/inf & 2 & $2,5 \%$ & 5 & $12,5 \%$ & 2 & $7,4 \%$ & 9 & $6,2 \%$ \\
\hline & TOTAL & 79 & $100,0 \%$ & 40 & $100,0 \%$ & 27 & $100,0 \%$ & 146 & $100,0 \%$ \\
\hline
\end{tabular}

Obs.: o número total de orientadores envolve 144 pessoas porém 2 declararam em seu currículo possuir 2 cursos de graduação.

Fonte: Seção de Pós-Graduação FSP/USP

Áreas consideradas importantes para a compreensão de questões pertinentes à saúde pública, e que pressupõem conhecimentos mais específicos de um profissional, como por exemplo, administração e economia, possuem apenas um orientador, mesmo existindo a possibilidade bem acessível, e a prática usual na FSP de credenciamento de professores de outras escolas. 
Não considerando o tipo de vínculo com a FSP, mas sim as áreas de concentração, observamos que os profissionais de saúde só não são maioria na Saúde Ambiental, que tem $25 \%$ de biólogos. Os engenheiros estão concentrados nessa área, compondo $18 \%$ do quadro, em porcentagem semelhante aos médicos.

A área SSP absorve a maior variedade de profissionais (14 diferentes profissões), com $24 \%$ de médicos, $14 \%$ de cientistas sociais e $14 \%$ de médicos veterinários. Os nutricionistas se concentram na NUT e compõem $44 \%$ da área seguidos dos médicos (17\%). A área Epidemiologia possui 51\% de médicos, 9\% estaticistas, e $9 \%$ biólogos.

O processo de credenciamento de orientadores é iniciado por solicitação de um dos departamentos da FSP e julgado pela CPG. Em 1997 a CPG, atendendo ao artigo 88 do Regimento Geral da USP, aprovou em sua 13a sessão, proposta de critérios para credenciamento e recredenciamento dos orientadores que, em 1998, ainda não havia sido aprovada pela Congregação da FSP. Na realidade esse processo foi desencadeado pela Pró-Reitoria de Pós-Graduação da USP que, considerando a relação orientador-orientando um dos elos mais críticos na formação do pós-graduando, pôs em discussão os critérios que as CPGs vêm adotando. Nomeou cinco subgrupos, "correspondendo às áreas de tecnologias, ciências básicas, humanidades, matemática, e ciências da saúde, cuja tarefa foi a de discutir as características próprias da produção acadêmica de cada área, e propor critérios que pudessem nortear o processo de credenciamento". Desse trabalho, resultou a idéia de que "a despeito da diversidade da natureza da produção acadêmica em cada área, deveria haver critérios mínimos de credenciamento de orientadores para toda a USP”. Em abril de 1998, o Conselho de Pós-Graduação aprovou esses critérios que ainda serão submetidos às Câmaras ${ }^{26}$.

Ao final desse processo, provavelmente a FSP poderá rever a sua proposta, se for o caso, e aprová-la. Por enquanto o recredenciamento se dá automaticamente. A proposta da CPG basicamente inclui a avaliação, a cada cinco anos, de publicações (mínimo uma a cada dois anos); de atividades de ensino; e de extensão, incluindo-se também aí a avaliação pelo aluno de seu orientador.

26 Conselho de Pós-Graduação da Universidade de São Paulo, sessão de 27 de abril de 1998. 
Segundo levantamento da SPG/FSP a produção científica por orientador em 1997, foi de 0,6 na área de concentração EPI; 0,6 na SSP; 0,2 na NUT; 0,4 na SA; 0,8 na SMI; 0,6 na AH; e 0,5 para o conjunto de orientadores da FSP. Estas médias são calculadas pela CPG tendo como base o número total de orientadores, dividido pelo número de publicações informadas pelo corpo docente na ativa.

A exigência mínima para credenciamento é a de possuir o título de doutor. Entre os professores da FSP credenciados para orientação 43 (55,84\%) são doutores, 14 (18,18\%) são professores associados e 20 (25,97\%) titulares ${ }^{27}$.

Analisando há quanto tempo os orientadores se doutoraram encontramos para a maioria dos professores (62\%) uma distribuição que variou uniformemente entre três e 16 anos de término do doutorado. Porém 28 (19\%) têm entre 20 e 30 anos de titulação.

Em relação ao local de doutoramento, $64 \%$ do corpo de orientadores fizeram doutorado na própria FSP. De certa forma, esta alta porcentagem é esperada uma vez que a FSP é a escola que forma o maior número de mestres e doutores em saúde pública no Brasil e como apresentado no Quadro 1 (Capítulo I) até poucos anos atrás, o número de cursos de pós-graduação em saúde pública no país era pequeno.

No entanto uma das críticas apresentadas pela CAPES à FSP é a "excessiva endogenia" presente no corpo docente. Apenas três professores cursaram doutorado fora do Brasil; $83,3 \%$ o fizeram na própria USP. Oito docentes $(5,3 \%)$ não se doutoraram em escolas da área da saúde, os demais $(28,6 \%)$ são de escolas da área da saúde com uma predominância para a medicina (Tabela 7).

27 As categorias docentes na USP são as seguintes: auxiliar de ensino, assistente, professor doutor, professor associado e professor titular. As três últimas correspondem à carreira docente na USP (Artigo 76 do Estatuto da USP, 1988). 
Tabela 7 - Pós Graduação strictu sensu FSP/USP

Orientadores segundo local de doutoramento ,1996.

\begin{tabular}{|c|c|c|c|c|c|c|c|c|c|c|c|c|c|c|}
\hline Escola & \begin{tabular}{|c|} 
SSP \\
$n^{0}$ \\
50 \\
\end{tabular} & $\begin{array}{c}\% \\
100 \\
\end{array}$ & $\begin{array}{c}\text { AH } \\
n^{\circ} \\
7\end{array}$ & $\begin{array}{c}\% \\
100\end{array}$ & $\begin{array}{c}\text { EPI } \\
n^{0} \\
35\end{array}$ & $\begin{array}{c}\% \\
100\end{array}$ & $\begin{array}{c}\text { SMI } \\
\mathrm{n}^{0} \\
12\end{array}$ & $\begin{array}{c}\% \\
100\end{array}$ & $\begin{array}{l}\text { SA } \\
\mathrm{n}^{0} \\
28\end{array}$ & $\begin{array}{c}\% \\
100\end{array}$ & $\begin{array}{c}\text { NUT } \\
\mathrm{n}^{\circ} \\
18\end{array}$ & $\begin{array}{c}\% \\
100\end{array}$ & $\begin{array}{c}\text { Total } \\
n^{0} \\
150 \\
150\end{array}$ & $\begin{array}{c}\% \\
100\end{array}$ \\
\hline EE/USP & 1 & 2 & - & - & - & - & - & - & - & - & - & - & 1 & 1 \\
\hline EESC/USP & - & - & - & - & - & - & - & - & 1 & 4 & - & - & 1 & 1 \\
\hline EP/USP & - & - & - & - & - & - & - & - & 1 & 4 & - & - & 1 & 1 \\
\hline FCF/USP & - & - & - & - & - & - & - & - & - & - & 1 & 6 & 1 & 1 \\
\hline FCM/UNICAMP & 1 & 2 & - & - & - & - & - & - & - & - & - & - & 1 & 1 \\
\hline FFLCH/USP & - & - & - & - & - & - & - & - & 1 & 4 & - & - & 1 & 1 \\
\hline FM/USP & 3 & 6 & 1 & 14 & 3 & 9 & - & - & 1 & 4 & 2 & 11 & 10 & 7 \\
\hline FMRP/USP & 1 & 2 & 1 & 14 & - & - & - & - & - & - & - & - & 2 & 1 \\
\hline FMVZ/USP & 2 & 4 & - & - & 1 & 3 & - & - & - & - & - & - & 3 & 2 \\
\hline FO/USP & 1 & 2 & - & - & - & - & - & - & - & - & - & - & 1 & 1 \\
\hline FOB/USP & - & - & - & - & 1 & 3 & - & - & - & - & - & - & 1 & 1 \\
\hline fora do Brasil & 1 & 2 & 1 & 14 & - & - & - & - & - & - & 2 & 11 & 4 & 3 \\
\hline FSP/USP & 32 & 64 & 3 & 43 & 27 & 77 & 9 & 75 & 14 & 50 & 11 & 61 & 96 & 64 \\
\hline IB/UNESP & 1 & 2 & - & - & - & - & - & - & - & - & - & - & 1 & 1 \\
\hline IB/USP & - & - & - & - & - & - & - & - & 3 & 11 & - & - & 3 & 2 \\
\hline ICB/USP & 2 & 4 & - & - & - & - & - & - & 1 & 4 & - & - & 3 & 2 \\
\hline IP/USP & - & - & - & - & - & - & - & - & 1 & 4 & - & - & 1 & 1 \\
\hline não se aplica & - & - & - & - & 2 & 6 & - & - & 1 & 4 & - & - & 3 & 2 \\
\hline s/inf & 5 & 10 & 1 & 14 & 1 & 3 & 1 & 8 & 4 & 14 & 1 & 6 & 13 & 9 \\
\hline UNIFESP & - & - & - & - & - & - & 2 & 17 & - & - & 1 & 6 & 3 & 2 \\
\hline
\end{tabular}

Fonte: Seção de Pós-Graduação FSP/USP

Quanto ao tempo de credenciamento, os professores são orientadores em $36,9 \%$ dos casos há menos de quatro anos; $13,3 \%$ orientam há mais de 20 anos. Dentre os externos à FSP, $60 \%$ estão credenciados há menos de quatro anos, chama à atenção o fato de dois professores encontrarem-se nessa situação há mais de 20 anos.

Naturalmente a maior porcentagem de orientadores antigos (mais de 20 anos) recai sobre os aposentados. Lembramos a recente "onda" de aposentadorias devido à "nova lei da previdência" que poderia ter determinado a aposentadoria de professores (22\% dos aposentados) com menos de 6 anos de orientação (Tabela 8).

A proporção de orientadores do sexo masculino está em torno de 51 a $58 \%$ conforme a área de concentração, com exceção da SA que tem $64 \%$ de homens e a NUT com maior porcentagem de mulheres (78\%) (Gráfico 7). 
Tabela 8 - Pós Graduação strictu sensu FSP/USP

Orientadores segundo tempo de credenciamento e vínculo com a FSP, 1996.

\begin{tabular}{|c|c|c|c|c|c|c|c|c|}
\hline \multirow{2}{*}{$\begin{array}{l}\text { Tempo } \\
\text { (anos) }\end{array}$} & \multicolumn{2}{|c|}{ aposentado } & \multicolumn{2}{|c|}{ externo } & \multicolumn{2}{|c|}{ na ativa } & \multicolumn{2}{|c|}{ Total } \\
\hline & núm & $\%$ & núm & $\%$ & núm & $\%$ & núm & $\%$ \\
\hline 0 & - & - & 8 & 20,0 & 11 & 14,3 & 19 & 13,2 \\
\hline 1 & 2 & 7,4 & 3 & 7,5 & 6 & 7,8 & 11 & 7,6 \\
\hline 2 & - & - & 4 & 10,0 & 4 & 5,2 & 8 & 5,6 \\
\hline 3 & - & - & 6 & 15,0 & 3 & 3,9 & 9 & 6,3 \\
\hline 4 & - & - & 3 & 7,5 & 3 & 3,9 & 6 & 4,2 \\
\hline 5 & - & - & 4 & 10,0 & 4 & 5,2 & 8 & 5,6 \\
\hline 6 & 4 & 14,8 & 4 & 10,0 & 9 & 11,7 & 17 & 11,8 \\
\hline 7 & 2 & 7,4 & 4 & 10,0 & 6 & 7,8 & 12 & 8,3 \\
\hline 8 & 2 & 7,4 & - & - & 2 & 2,6 & 4 & 2,8 \\
\hline 9 & - & - & 1 & 2,5 & - & - & 1 & 0,7 \\
\hline 10 & 1 & 3,7 & - & - & 1 & 1,3 & 2 & 1,4 \\
\hline 11 & 1 & 3,7 & - & - & 5 & 6,5 & 6 & 4,2 \\
\hline 12 & - & - & - & - & 3 & 3,9 & 3 & 2,1 \\
\hline 13 & 1 & 3,7 & - & - & 2 & 2,6 & 3 & 2,1 \\
\hline 14 & - & - & - & - & 1 & 1,3 & 1 & 0,7 \\
\hline 15 & - & - & - & - & 3 & 3,9 & 3 & 2,1 \\
\hline 16 & 2 & 7,4 & - & - & 1 & 1,3 & 3 & 2,1 \\
\hline 17 & 1 & 3,7 & - & - & 1 & 1,3 & 2 & 1,4 \\
\hline 18 & 1 & 3,7 & - & - & 1 & 1,3 & 2 & 1,4 \\
\hline 21 & - & - & - & - & 2 & 2,6 & 2 & 1,4 \\
\hline 22 & - & - & - & - & 1 & 1,3 & 1 & 0,7 \\
\hline 23 & 1 & 3,7 & 1 & 2,5 & 1 & 1,3 & 3 & 2,1 \\
\hline 24 & 1 & 3,7 & - & - & 3 & 3,9 & 4 & 2,8 \\
\hline 25 & - & - & 1 & 2,5 & 1 & 1,3 & 2 & 1,4 \\
\hline 26 & 6 & 22,2 & - & - & 3 & 3,9 & 9 & 6,3 \\
\hline 27 & 1 & 3,7 & - & - & - & - & 1 & 0,7 \\
\hline 29 & 1 & 3,7 & - & - & - & - & 1 & 0,7 \\
\hline s/inf & - & - & 1 & 2,5 & - & - & 1 & 0,7 \\
\hline Total & 27 & 100,0 & 40 & 100,0 & 77 & 100,0 & 144 & $\overline{100,0}$ \\
\hline
\end{tabular}

Fonte: Seção de Pós-Graduação FSP/USP

A distribuição dos orientadores quanto à faixa etária mostrou que 68 $(45,33 \%)$ estão entre 45 e 54 anos. A área de Nutrição é a única com orientador com menos de 34 anos. As outras áreas tem comportamento semelhante ao conjunto da FSP (Gráfico 8).

Ao separarmos o grupo de orientadores com vínculo empregatício na FSP observamos um quadro aproximado ao geral. 


\section{Gráfico 7 - Pós Graduação Strictu Sensu FSP/USP \\ Orientadores segundo sexo, 1996.}
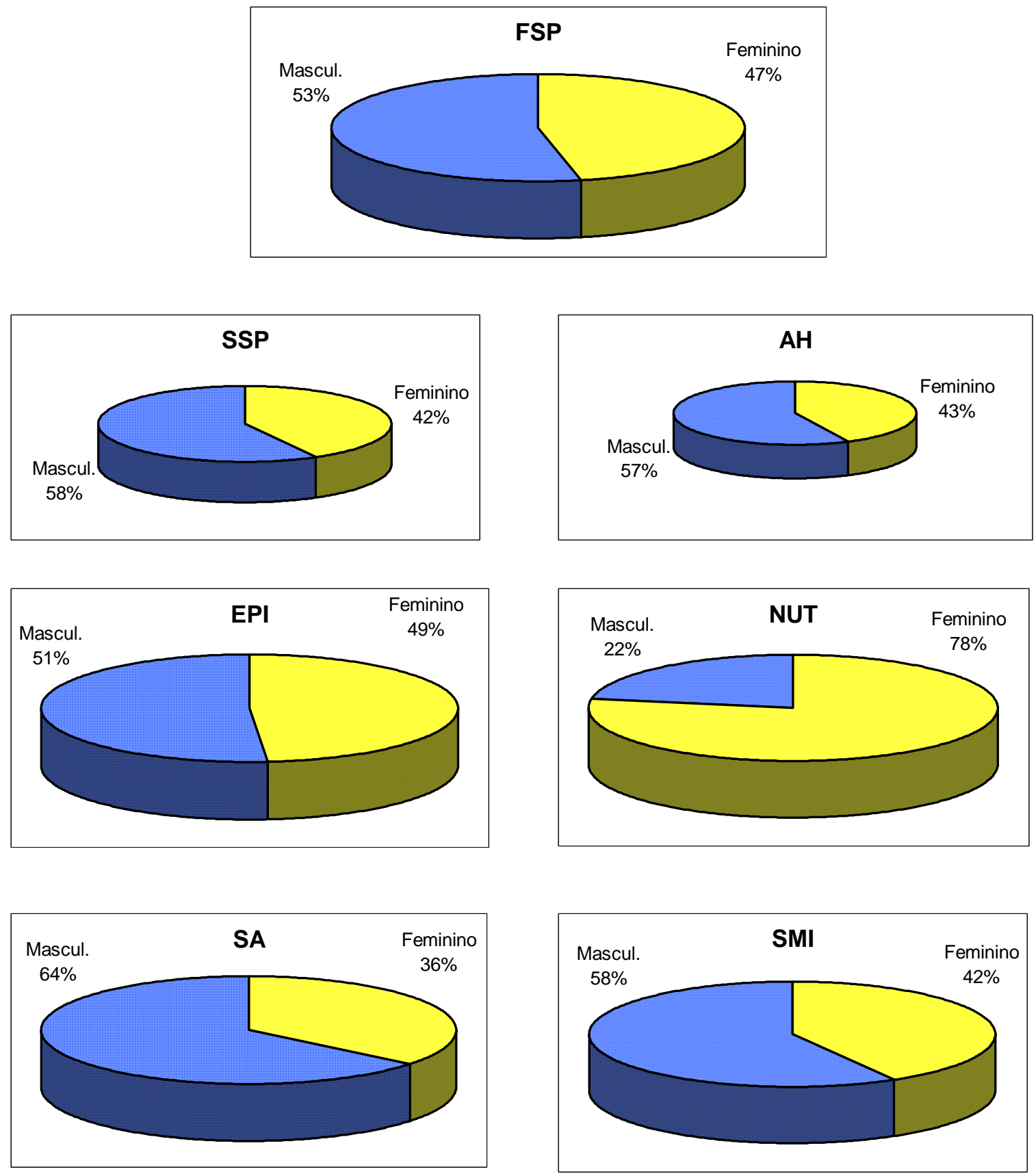

Fonte: Seção de Pós-Graduação FSP/USP 
Gráfico 8 - Pós Graduação Strictu Sensu FSP/USP

Orientadores segundo faixa etária, 1996.
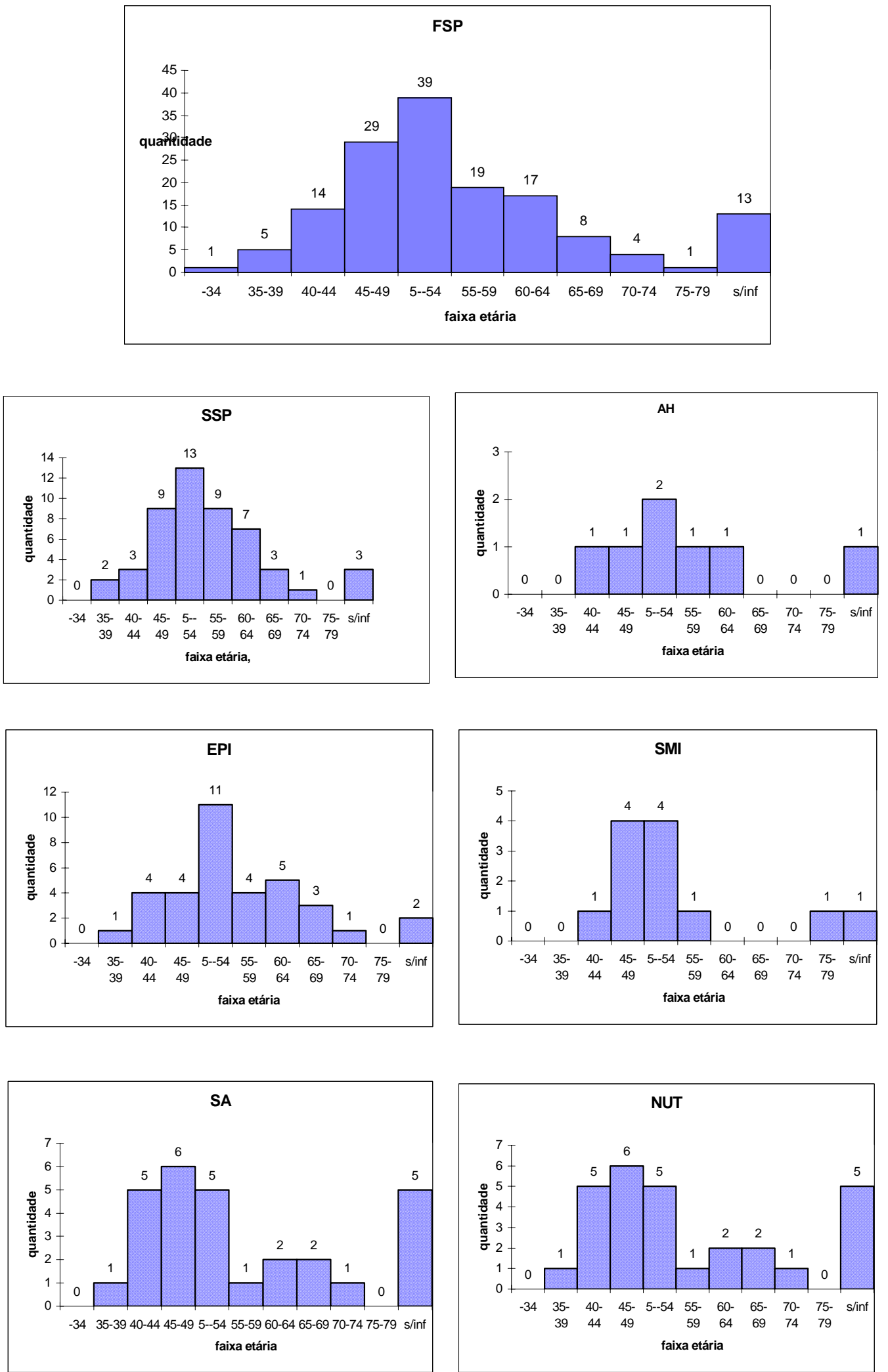

Fonte: Seção de Pós-Graduação FSP/USP 
Os orientadores com vínculo empregatício na FSP possuem em sua maioria (78\%) regime de trabalho de dedicação integral à docência e à pesquisa. As áreas de Nutrição e Epidemiologia tem 100\% dos seus orientadores nesse regime e as de SSP e AH são as únicas com professores em regime de turno parcial, que no conjunto constituem $5 \%$ do corpo de orientadores ${ }^{28}$ (Gráfico 9).

Gráfico 9 - Pós Graduação strictu sensu FSP/USP

Orientadores com vínculo empregatício na FSP/USP segundo

regime de trabalho e área de concentração, 1996.
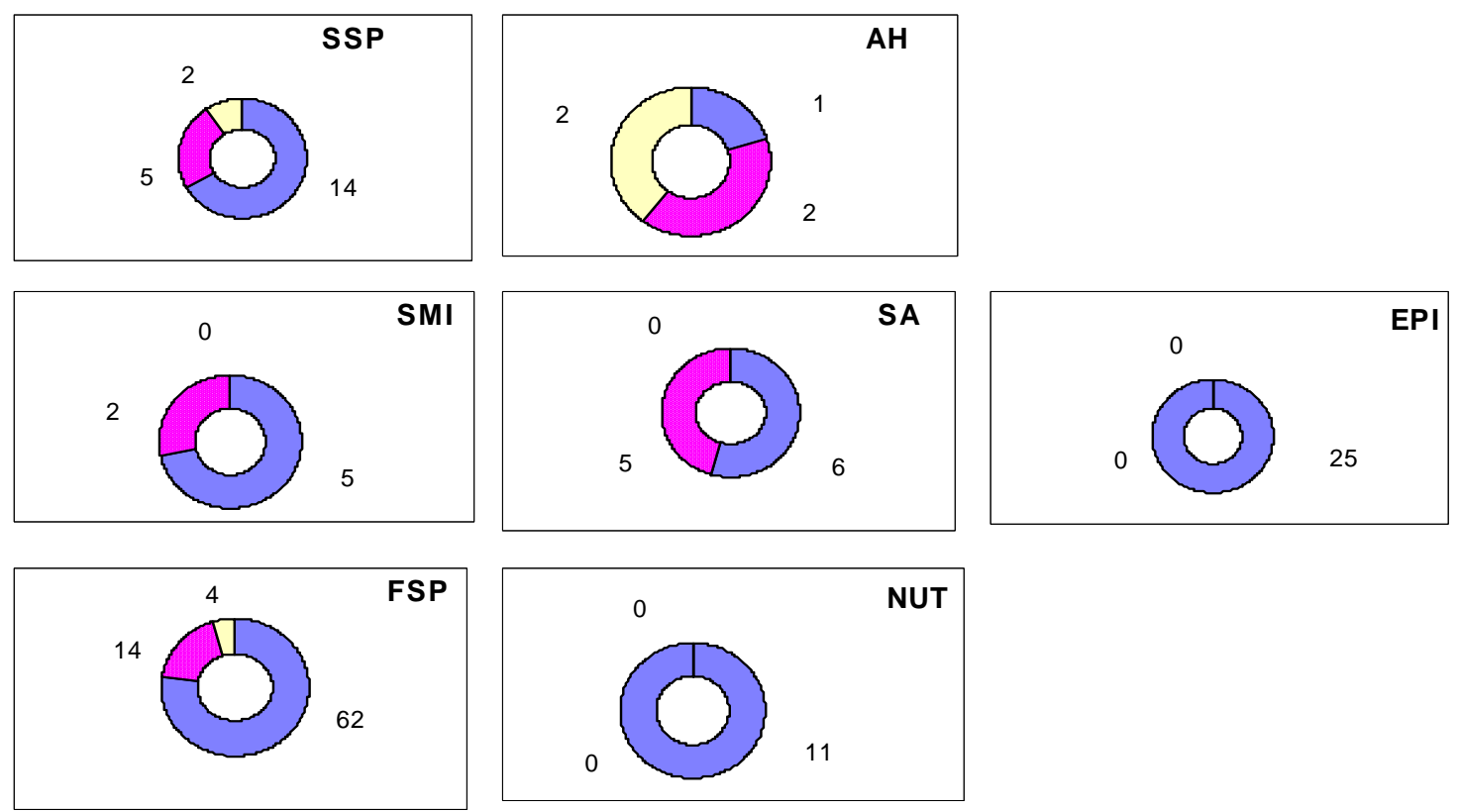

Legenda

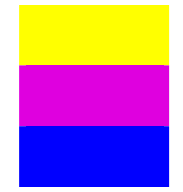

RTP - Regime de Turno Parcial (12h/semanais)

RTC - Regime de Turno Completo (24h/semanais)

RDIDP - Regime de Dedicação Integral à Docência e à Pesquisa (40h/semanais)

Fonte: Seção de Pós-Graduação FSP/USP

28 São três os Regimes de trabalho docente na USP: RDIDP - Regime de Dedicação Integral à Docência e à Pesquisa - "regime preferencial do corpo docente da USP", tem a finalidade de estimular e favorecer a realização da pesquisa nas diferentes áreas do saber e do conhecimento, assim como, correlatamente, contribuir para a eficiência do ensino e da difusão de idéias e conhecimentos para a comunidade; RTC - Regime de Turno Completo - o docente deve trabalhar por 24 horas semanais em atividades de ensino, pesquisa, bem como de extensão de serviços à comunidade, se for o caso; RTP - Regime de Turno Parcial - o docente deve trabalhar na Universidade por 12 horas semanais em atividades de ensino. (USP, 1989) 
Segundo a Resolução CPG/FSP 03/94 de 25 de abril de 1994, "Os orientadores credenciados pela CPG poderão aceitar alunos para orientação obedecendo aos seguintes limites: docentes em RDIDP - 8 orientandos; docentes em RTC e aposentados - 6 orientandos; docentes em RTP - 3 orientandos; e Orientadores estranhos à FSP - 3 orientandos".

A proposta de critérios para credenciamento e recredenciamento de orientadores, em discussão na FSP estabelece que "o orientador recém-credenciado no seu primeiro ano só poderá ter orientandos em número correspondente à metade do que Ihe seria permitido por seu regime de trabalho, podendo preencher as vagas restantes após a conclusão da primeira orientação". Desde 1990 os novos orientadores na FSP, independente da experiência anterior em outras escolas, são credenciados apenas para o mestrado, e podem solicitar credenciamento para o doutorado assim que um orientando seu termine o mestrado.

Considerando a citada resolução e o quadro de orientadores, a capacidade da FSP em 1996 seria de orientar 889 alunos. Não estava disponível o número total de alunos matriculados nessa época mas, em dezembro de 1997, eram 346 mestrandos e 224 doutorandos, num total de 570 alunos.

O número médio de orientandos por orientador em dezembro de 1997 foi de 5,4 para EPI; 4,9 para SSP; 4 para NUT; 4,3 para SA; 5,4 para SMI; 5,6 para AH; e 4,9 para a FSP como um todo.

A avaliação da CAPES do biênio 94/95 considerou o "corpo docente titulado, competente, condizente com o perfil do curso, atendendo às áreas de concentração. Relação orientador/orientando discretamente elevada para o mestrado, observando-se excesso para alguns orientadores. Não existem professores visitantes, realçando a endogenia na formação da equipe docente do curso". 


\section{Capítulo III - SUJEITOS, PROCESSOS E REPRESENTAÇÕES}

Na perspectiva de compreender como vem ocorrendo a pós-graduação na FSP, buscamos no currículo dos cursos de mestrado e doutorado o elemento de aproximação dos sujeitos que compõem a pós-graduação da FSP - alunos e professores.

Nesse sentido entendemos currículo como apresentado por SAVIANI (1998) e transcrito a seguir:

“ ... o currículo responde à pergunta 'o que fazer' ... currículo se refere ao conjunto das atividades e sua distribuição no espaço e tempo escolares, atividades essas organizadas e realizadas tendo em vista os objetivos que se busca atingir. Por isso, é possível dizer que o currículo pleno de uma escola é essa própria escola funcionando. ... A questão central para o êxito curricular parece residir, pois, em medidas que transformem a escola num espaço adequado e, por que não dizer, atraente, com professores identificados com sua escola, fortemente motivados se relacionando com alunos constantemente estimulados".

Nessa visão consideramos a complementaridade dos papéis do aluno e do professor como fundamentais para o desenvolvimento de um currículo.

Destacamos na nossa análise os aspectos referentes aos projetos acadêmicos dos alunos, os projetos dos professores e a estrutura de curso proposta pela FSP. Quanto à estrutura enfocaremos os momentos do curso que sobressaíram mais fortemente nas entrevistas, como reveladores da dinâmica que mostra o projeto educacional da Faculdade. São eles: o processo de seleção de candidatos à pós-graduação, o desenvolvimento das disciplinas obrigatórias e eletivas, o processo de orientação e o ambiente escolar.

Os projetos acadêmicos foram identificados nos depoimentos a partir do relato de histórias profissionais, expectativas, e críticas ou comentários sobre o desenvolvimento do curso. 


\section{AFINAL, QUEM FAZ NO COTIDIANO DA FACULDADE A PÓS-GRADUAÇÃO?}

\subsection{ALUNOS}

A saúde pública é notadamente um campo de conhecimento pósgraduado interdisciplinar e multiprofissional. (MINAYO, 1997)

Como descrito anteriormente, alunos e professores da FSP possuem diferentes formações em nível de graduação e em determinado momento de sua vida profissional ou acadêmica se orientam para a área de especialidade em saúde pública "transformando-se" em sanitaristas.

Ao buscar compreender o caminho e as motivações que conduzem profissionais de diferentes formações básicas à saúde pública, percebemos que essa orientação veio se conformando de diferentes maneiras.

Nesse caminho identificamos a partir da visão que eles traziam sobre ser sanitarista, três grupos de alunos chegando à pós-graduação da FSP.

O primeiro grupo conta com orgulho sua trajetória profissional em saúde pública, está trabalhando em serviços de saúde e/ou em universidades e relata ter vivido um processo de migração ou conversão profissional. Poderíamos dizer que representam a figura mais tradicional do sanitarista.

Outros alunos também têm inserção profissional definida mas não se apresentaram como sanitaristas, trabalham em áreas afins à saúde pública e não em serviços de saúde em sentido mais estrito.

O terceiro grupo é representado por aluno mais jovem, sem vínculo empregatício, ex-bolsista de iniciação científica, buscando iniciar-se na carreira docente e na área da saúde pública.

\section{Saúde pública - conversão profissional}

A história profissional descrita por um grupo de alunos entrevistados mostrou que eles já possuíam uma trajetória em saúde pública ao iniciar a pósgraduação. São alunos que se dizem mais claramente sanitaristas. 
(5A) ... na época que eu fazia o curso, o pessoal que não era da saúde pública, que não era sanitarista já ... o pessoal achou uma dificuldade danada de acompanhar aquele curso ... saber o que estava acontecendo ... Tentar entender ...

Relatam ter interesse por questões coletivas desde o seu curso de graduação, parecendo que naquele momento a percepção da orientação profissional em saúde pública já era presente.

(1A) ... porque trabalho com saúde pública, sempre trabalhei com saúde pública. Eu sou cirurgião dentista de formação e, desde o segundo ano da escola, quando ... 99,9\% dos colegas de turma discutiam onde montar um consultório, né, que características o consultório deveria ter ... eu já destoava um pouco ... entrava nessas discussões mas com questões para os outros e não para mim. Porque para mim, desde o segundo, terceiro ano de escola, eu sabia que queria trabalhar com saúde pública ... Não sabia onde nem como ... nem quando, mas sabia que isso me interessava, porque tinha toda uma avaliação do campo de trabalho, né, que é odontologia, saúde bucal coletiva e me interessava essa dimensão populacional, essa dimensão coletiva dos problemas de saúde bucal.

(2A) ... acho que as origens desse curso (doutorado), na verdade, estão na minha graduação. Eu fui fazer veterinária, com grande interesse em saúde pública. Sempre fui interessada com a questão ... que é uma aproximação para a saúde pública, era mais talvez o interesse maior pelo público, pela população, uma coisa mais na coletividade ... sempre tive um grande interesse pelas questões coletivas ... Antes de fazer veterinária, quer dizer, antes de entrar na universidade, eu tinha ... não tinha tanta certeza o que seria saúde porque eu tinha interesse por sociologia também ... eu queria um pouco sociologia, um pouco a área da saúde ... E acabei indo fazer veterinária de uma forma muito romântica. Ontem até estava falando nisso com uns amigos ... porque eu fui numa assim ... numa idéia muito romântica de veterinária, a coisa de ecologia ... os animais ... o meio ambiente ... da importância da veterinária para a saúde da população ... quer dizer, era uma coisa que eu considero muito romântica porque na realidade a veterinária ainda é uma medicina muito econômica ... e mal, né ... e pouco voltada mais assim ... com uma preocupação com a saúde pública dentro da veterinária. ... E daí eu fiquei um período na veterinária e fui realmente para a saúde pública, com um interesse grande na área de alimentos.

(3A) ... trabalhar na saúde pública é uma coisa que eu defini já faz muito tempo, quando eu comecei a estudar medicina ... então no quinto semestre de medicina eu falei que ia fazer aquilo que me interessava, saúde pública. A clínica, eu gosto muito da clínica, só que na verdade eu gosto mais da saúde pública ... Porque eu pensava - eu posso na saúde pública fazer muito mais coisas, por mais pessoas, do que na clínica. 
Porque na clínica você trabalha individualmente, e você sabe que não resolve nada ... A saúde pública pelo menos ... eu pensava, inclusive ingenuamente, que isso podia servir para fazer alguma coisa mais interessante ... por exemplo, resolver problemas da população da maioria da gente, não? E depois a gente sente uma grande frustração, né, porque não é assim ... é uma coisa que você trabalha na saúde pública com muitas limitações, principalmente do poder político, onde as intervenções não são exatamente como você pensa que poderiam ser feitas (...), esse é o sentido de trabalhar na saúde pública, no sentido do coletivo ...

(5A) ... Aí no segundo semestre da minha residência, eu resolvi fazer o curso de saúde pública, o curso de saúde pública curto. Eu fiz essa opção porque ... tem até uma história antiga aí ... do meu segundo ano de residência, andar descontente e tal ... E fui fazer o curso de saúde pública. E foi na época que o Leser fazia a gente fazer o curso de saúde pública e admitia na Secretaria. Então, eu fui trabalhar como médica sanitarista ... e abandonei a clínica, nunca mais trabalhei com clínica.

(6A) ... Sempre gostei de saúde pública. Se existisse uma graduação em saúde pública eu tinha feito, mas como não existia ... a opção foi fazer nutrição que era uma área que eu gostava muito ... Então, o interesse pela saúde pública foi como eu falei, desde que eu resolvi fazer faculdade, né, as áreas que eu escolhi fazer monitoria e depois bolsista de iniciação científica, sempre foi nessa área, de saúde pública.

Uma aluna assim se referiu ao campo da saúde pública (10A)... acho que a saúde pública é o espaço da migração profissional, cabe todo mundo lá...

Os professores também trazem em seus depoimentos experiências semelhantes.

(1P)... a minha formação eu sou pediatra, fiz residência de pediatria e trabalhei em pediatria. Mas assim, eu fiz primeiro residência, o $R 1$ e $R 2$ normais, aí depois no R3 eu já fui para uma área que é pediatria social, uma interface com medicina preventiva, já fui trabalhar numa comunidade, então já sai da ...

(8P) ... sou médico. Comecei minha formação ... e depois parei o curso de medicina, durante 4 anos, no segundo ano parei ... aí depois, fui trabalhar num laboratório farmacêutico ... Bom ... aí teve uns caminhos pela sociologia. Agora que eu percebo que aí já começou um certo enfoque diferente de medicina, né ... do enfoque biológico, de tratamento, etc. Aí volto, acabei terminando meu curso de medicina ... ... aí se colocou a questão da residência, profissionalmente como iria me colocar e aí então decidi (...) sempre houve essa preocupação ... sempre houve essa preocupação de trabalhar com o coletivo, social ... mas de uma forma bastante confusa. E quando optei por fazer a residência médica em preventiva, né, eu tive duas opções, na FIOCRUZ e 
aqui na FM. E eu acabei decidindo por aqui por conta da FIOCRUZ me colocar imediatamente numa proposta de pesquisa, uma proposta de trabalhar com dados ... E eu assim ... embora essa fosse uma preocupação, trabalhar com a questão coletiva ... que se afasta da clínica, se distingue, né ... eu naquele momento vacilei ... como se a coisa não estivesse colocada para mim. $E$ aqui a preventiva tinha uma perspectiva de uma formação clínica, ao mesmo tempo em que se passava por uma discussão das questões coletivas ... da saúde coletiva. Então, eu optei por essa outra opção, ainda híbrida, de formação.

Os entrevistados se reconhecem como sendo na época da graduação sonhadores, pessoas com visões românticas e ingênuos.

As lembranças desses alunos apontam, nessa fase, a existência de uma oposição entre saúde pública e prática clínica, enfoque biológico e enfoque social, que permeiam a passagem para a especialidade saúde pública.

O movimento interno e pessoal de mudança para a saúde pública foi feito com conflito e abandono. Abandono da primeira profissão com a incorporação de um ofício especializado que pressupõe o aprendizado de novos conhecimentos e instrumentos de trabalho. O movimento externo vai permitindo a aproximação com uma carreira que tem reconhecimento público de seu papel, era estruturada até há alguns anos atrás e de certa forma reunia pessoas com visões ou ideais semelhantes sobre saúde.

A motivação para a saúde pública está também influenciada pela visualização ou a busca na saúde pública de um espaço de militância política, sendo esta visão trazida pelos alunos ou mesmo professores que se graduaram na década de 70. Época marcada pelo regime militar quando muitos jovens procuraram diferentes formas de militância. O serviço público parecia trazer a possibilidade de realização de alguma expectativa política.

(5A) P: você fez o curso curto na Faculdade em $76 \ldots$

R: 76 ... em 76, isso mesmo ... O segundo curso ...

Muito bem ... aí me dediquei ao serviço e bem dentro daquela postura de querer ... de acreditar que a saída era o serviço público ... sempre militei num monte de instituições ... e outros locais e tal ... e fiz aquele plano que a saída era o serviço público, e me dediquei a isso a minha vida inteira

(8P) me aproximei da epidemiologia pela epidemiologia social. Mas é interessante que naquele momento observei algumas deficiências da 
abordagem (...) Hoje assim, 20 anos depois, acho que as visões são diferentes ... aquele enfoque da epidemiologia social era muito importante naquele momento político que o país passava, né ... não só o país como a própria América Latina como um todo. E hoje as coisas estão um pouco mais serenas ... é uma questão política muito bem colocada, bem delimitada, né ...

(1A) até porque eu tenho uma certa atividade na área de saúde pública ... não só profissionalmente, mas eu participo de entidades de saúde pública, fui dirigente de entidades, fundei uma entidade nessa área, né. Eu sou um dos fundadores do CEBES ${ }^{29}$, que é uma das entidades, talvez das mais importantes na área de saúde pública no Brasil hoje.

O despertar para a saúde pública também se deu a partir da vivência de alguma experiência na área. O exercício de práticas sanitárias é valorizado no processo de "conversão" para a saúde pública.

(7A) ... eu sempre me interessei pela área de saúde e eu decidi que queria ser enfermeira no colegial, no segundo ano colegial, no começo do colegial ... Eu queria ser enfermeira médico-cirúrgica, para trabalhar em hospital. Eu resolvi fazer saúde pública quando fiz o Projeto Rondon, em 1978 ... em janeiro ... fui para o sertão do Piauí ... aí eu vi que ... que meu caminho era trilhar pela saúde pública ... me apaixonei pela saúde pública ... Que eu não gostava muito ...

(7P) ... na verdade no Pará, em Belém, não tinha uma faculdade adequada para o que eu queria estudar (História Natural), que era exatamente mosquito.

(...) ele já me conhecia, sabia que eu era um sonhador por natureza, e aí ele falou, um dia me telefonou e falou - tem um lugar que é excelente para você, alguém para trabalhar com mosquito, para catar mosquito, aí eu trabalhei uns 4 anos ... 5 anos na erradicação de malária (..) $E$ nessa vez eu também larguei a malária pelo museu Goeldi, para ganhar menos e com menos segurança. Passei de funcionário público, de nível médio, para um bolsista.

(...) R: ... não o curso, o curso talvez tenha aberto um pouco, né, mas foi o fato de eu dar aula depois ... Mais tarde, exatamente em 74, 73 ... é ... 73, 74, eu fui obrigado a ajudar na epidemiologia. E aí comecei a fazer alguns estágios e algumas atividades junto com. A T., lembro que naquele ano de 74 a gente começou a fazer o estágio de campo, particularmente ... acho que foi em abril mesmo o campo para a gente, e o A T. foi o grande treinador da gente para o estágio de campo e mostrava como era que funcionava essa atividade de saúde pública.

\footnotetext{
29 O CEBES-Centro Brasileiro de Estudos da Saúde, segundo FLEURY (1995), representou na conjuntura de 1976/1979, "a pedra fundamental do movimento sanitário como movimento social organizado. Diferenciando-se das demais entidades, separadas por categorias, ... foi uma entidade organizadora do movimento de profissionais de Saúde que difundiu um pensamento político acerca das questões da Saúde através de uma linha editorial e de outras atividades; além disso, foi um centro de estudos e de elaboração de propostas alternativas à política de Saúde vigente. O CEBES é a 'transposição' de um pensamento nascido nas universidades para o seio da sociedade civil, e faz a articulação do movimento sanitário com os demais movimentos sociais".
} 
Então, a partir desse momento comecei a ver a epidemiologia, quer dizer, a sentir a epidemiologia. Até então a epidemiologia não passava de uma ciência teórica que nunca ... tinha estudado um pouco e mais nada. Mas agora, a partir desse momento começou a me abrir ... começou a vir essa dimensão, a sentir a cultura da epidemiologia, através da própria saúde pública. E foi exatamente no estágio de campo, no meu estágio de campo de 74, 75, quando eu fazia parte de um grupo e começamos a coordenar o trabalho de campo com os alunos

Percebemos nos depoimentos que os alunos têm um grande repertório de experiências profissionais, têm orgulho de suas atividades nos serviços de saúde e não se sentem iniciantes na Saúde Pública.

(5A) E aí como médica sanitarista trabalhei como diretora de unidade, como assessora ... depois na Coordenadoria de Saúde da Comunidade antiga ... e depois fui para o nível central e fiquei praticamente o tempo todo no nível central, né. Mas eu passei por todas as fases, eu fui diretora desde o postinho, pequeno, lá no fim do mundo, em J. Depois um posto de saúde maior ... só cheguei no nível central depois de ter ficado ... acho que 8 anos no nível local, né. Então assim, conheço bem a Rede ...

(2A) ... E eu era a professora referência para isso aí, porque eu ao mesmo tempo que estava no Departamento de Preventiva, estava na Vigilância Sanitária, na Secretaria da Saúde..

(1A) ... eu não era nenhum neófito em pesquisa, entendeu ... na área de saúde pública, eu trabalhava naquele momento, em 85 ... 86, eu tinha pelo menos aí uns ... 8 anos de trabalho em saúde pública.

Estas características provavelmente compõem o perfil de um número expressivo de pessoas envolvidas na pós-graduação da FSP - alunos ligados a serviços, alunos docentes universitários e os próprios professores da FSP.

Mesmo quando a motivação para a saúde pública foi apontada como presente desde a graduação, alunos e professores relataram ter tido primeiro experiência em sua própria área de formação básica, para depois a aproximação com o exercício da prática sanitária ir se concretizando.

Assumir essa "segunda profissão" era um processo para os sujeitos claramente legitimado pela prática profissional e formalmente pelo curso de especialização em saúde pública.

(1A) Na verdade, eu tenho uma história com a Faculdade de Saúde Pública, que é uma história que começa no início dos anos 80, já com a 
história do curso de especialização ... eu trabalhava como clínico em C. e queria fazer o curso de especialização aqui ... era uma aspiração que eu tinha, fazer o curso, ser especialista em saúde pública então eu fiz o curso com muito sacrifício.

(7A) (...) tenho 17 anos de formada, aliás .. 18. Então, eu sempre quis primeiro ter vivência no campo, como enfermeira, para poder depois buscar um curso. E durante esses anos todos, o curso de especialização ele era período integral, não favorecia (...) ... tinha que ser aqui na Faculdade de Saúde Pública.

O discurso dos alunos se assemelha ao modelo de formação de sanitarista da FSP. O valor dado pela FSP à experiência profissional em saúde pública ao longo dos anos, se mostra na exigência de experiência como prérequisito para cursar a especialização.

(6P) ... Em 75, quando cheguei aqui, em abril, não pude ficar na especialização e aí as enfermeiras (professoras) acharam que eu tinha que passar pelo centro de saúde ... eu já tinha feito um ano no Chile ... mas elas queriam que eu passasse um ano em centro de saúde (...) achei uma besteira ... mas eu gostava do curso ...

Essa exigência dava características uniformes ao grupo de alunos que durante muito tempo foram recebidos pela Faculdade - existia um caminho único para formação.

Consideramos este fato um indicador da continuidade da vocação inicial da FSP, a concepção de formação em saúde pública com vistas ao preparo para um específico serviço de saúde pública.

A motivação para a pós-graduação dos alunos ligados a serviço de saúde está, em primeiro lugar, associada à necessidade de titulação, desencadeada inicialmente até pelo próprio serviço, e ainda pela possibilidade de aperfeiçoamento profissional pessoal que pode abrir novas perspectivas de trabalho. É uma decisão que vai sendo moldada pelos diferentes momentos gerados nas situações de trabalho.

(5A)... quando fui para o Instituto de Saúde aí eu estava afins de fazer pesquisa ... eu falei - vou tentar pesquisar até na área de planejamento e tal ... E foi uma época também ... que não tinha recursos para nada ... o Instituto de Saúde estava assim meio abandonado ... não tinha recursos 
para pesquisa ... A Secretaria estava uma confusão danada ... e ... eu queria fazer uma pesquisa, mas não tinha mestrado então eu não poderia pleitear, por exemplo, recursos para ninguém, porque eu não tinha mestrado. Porque se você pleitear com qualquer órgão financiador, você tem que ter o mestrado. Então ... sabe quando você ... aí senti necessidade ... e aí que veio a vontade de fazer o mestrado ... Eu falei - bem, já que eu preciso disso para ... no Instituto de Pesquisa, eu vou fazer o mestrado -. Então eu comecei o mestrado nessa época ... só que depois disso, eu sai do Instituto, depois fiquei à disposição da Prefeitura, depois mudou o governo, eu mudei da Prefeitura para a Secretaria, aí terminei assumindo a direção do órgão técnico lá (...) e continuei o mestrado, mas me desliguei dessa parte, de onde eu queria mesmo que era a questão da pesquisa. Então, acho que isso é a motivação minha para entrar no mestrado ... que realmente não tinha perspectiva assim ...: de carreira universitária, não estava ligada nisso, né. No fim .... Sou fundamentalmente serviço, o meu negócio é esse. (...) Aí depois eu voltei para o serviço e continuei ... e aí qual foi minha motivação de manter ... terminei achando legal, ter um espaço também para fazer uma reflexão da minha prática ... estudar um pouco ... né ... e terminei que o mestrado hoje está virando quase que uma necessidade ... não de complementação, mas dentro da especialidade pós graduação, está virando quase que uma exigência para você ... mesmo dentro do serviço você ter algum tipo de ... sei lá ... aumentar a sua credibilidade, você poder ter outras alternativas de trabalho ... Por exemplo, na Prefeitura, apesar de você estar no serviço ... mestrado não devia ser um critério de promoção, de pontuação, por exemplo, mas virou ... né. É uma coisa meio estranha ... por que você valoriza um critério de quem está dentro de uma instituição de ensino ... mas ... eu acho que isso aí é a demonstração de como o mestrado e o doutorado está tendo significado na vida dos profissionais liberais no mercado de trabalho, né. Quer dizer, aquela especialização só já não é mais ... ela já é uma condição que agrega a possibilidade de você se dar melhor ou pior no mercado de trabalho. Então, acho que sim, terminei entrando agora nesse clima ... acho que é legal ter o mestrado ... abre outra perspectiva -, e aí eu já comecei a pensar na perspectiva também de ... até entrar numa instituição de ensino ... né ... já não fiquei tão avessa ... acho que até, de repente, com o mestrado eu posso estar trabalhando nessa perspectiva.

Os alunos docentes referem ter em sua trajetória profissional exercido funções em serviços de saúde e hoje ainda mantêm dois vínculos ou estão só na universidade. Eles estão procurando na pós-graduação dar continuidade à carreira docente, além de aperfeiçoamento intelectual.

(1A) vim com perspectiva de fazer um trabalho docente (...) uma das "exigências" (aspas dele), que me foi feita, que eu fizesse pós graduação ... E claro ... essa exigência também coincidiu com um interesse meu ... já era um outro contexto ... na pós graduação aqui (...). Terminei o mestrado em final de 93 ... ou 94 ... acho que 93 ... isso. E aí logo em seguida me 
inscrevi no doutorado e estou fazendo doutorado (...) foi um desdobramento esperado do fato de ter feito mestrado (...) foi uma exigência natural de desenvolvimento profissional $e$ de aperfeiçoamento intelectual e tudo mais.

(2A) terminei em 83 ... Tem muito tempo, né ... E ... bom, chegou o momento que eu falei - é ... agora está na hora mesmo, não dá mais para demorar para fazer esse doutorado -, porque eu queria ter um tempo para me dedicar a estudar mais algumas questões que estavam na minha cabeça. E quando esse tempo começou a ficar claro na minha cabeça que era agora, eu comecei a mudar de idéia em relação ao meu objeto de estudo. Porque também foi chegando num momento em que estava muito difícil manter a dupla militância técnica ... na Secretaria de Saúde e na Universidade. E eu sentia muita necessidade de concentrar mais meu tempo na Universidade. (...) comecei a pensar mais seriamente no meu tema. Uma vez que vigilância sanitária estava muito dentro de mim, da minha prática, por muitos e muitos anos (...) a experiência no ensino, a minha experiência na área de vigilância sanitária foi muito mobilizadora para num momento posterior, escolher o meu tema de interesse para trabalhar no doutorado - vigilância sanitária.

\section{Saúde pública: campo complementar}

Entre os alunos que percebemos como já definidos profissionalmente destacamos também a presença daqueles que não trazem a idéia de abandono da primeira profissão para entrar na saúde pública.

São profissionais de áreas que possuem interface com a saúde pública, mas eles não se apresentam como profissionais estritamente da área de saúde pública. Se aproximam para obter conhecimentos "técnicos" e titulação.

Os depoimentos dos alunos mostram a especialidade saúde pública como um complemento de sua formação na graduação e trazem a necessidade de aquisição de instrumental próprio da saúde pública para o desempenho de suas funções.

(9A) ... Bom, em 94 eu fui indicado para fazer aquele curso de especialização em engenharia, pela CETESB ... a CETESB tem mandado ultimamente dois alunos, dois funcionários por ano ... e a gente fica lá um ano inteiro ... fica um ano dispensado. Aí ... bom ... o mestrado aconteceu meio em conseqüência desse curso ali. Já era formado há 15 anos, não pensava mais em estudar.

$P$ : você se formou em engenharia ...

R: civil ... e aqui na CETESB, até começar esse curso sempre trabalhei mais com água, Sistema de Água. E a coisa vem mudando ... o 
tratamento de esgoto está cada vez mais ... as pessoas estão procurando mais tratamento de esgoto, né. E eu estava sentindo essa mudança e estava na faculdade e aproveitei, fiz inscrição no concurso de mestrado para ... mais para ganhar conhecimentos, né. Não tenho planos para ... seguir carreira, nada ...

Esse aluno diz que gostou da especialização, considerando-a suficiente em termos de saúde pública e no mestrado fez quase todas as disciplinas na Escola Politécnica/USP. Se fizer doutorado pretende fazer na Politécnica, buscando aprofundamento técnico.

Encontramos também os que tem na pós-graduação o início da formação em saúde pública, antes o esperado nessa situação seria cursar a especialização e não "passar" direto para o mestrado.

(10A) Outra coisa, antes disso tudo é assim, eu não tinha nenhuma intenção em seguir carreira acadêmica. Não queria fazer mestrado, não queria fazer doutorado, não queria fazer nada disso. Mas aí assim ... eu tinha necessidade de ver essa coisa desse outro lado ... eu fiz ciências sociais, trabalhava numa equipe multiprofissional, trabalhava com saúde, tinha um médico, psicóloga ... a gente faz pesquisa mas assim o meu departamento é mais médico e social mesmo. Então, eu tinha necessidade de ver o outro lado, que não tinha ... por exemplo, algumas coisas de epidemiologia ... eu não tinha, eu não tinha tido nas ciências sociais. A sociais é muito assim ... ela não te prepara para as várias alternativas que você tem para continuar depois, né. Então eu ficava -ah, que eu faço? - Aí eu vi o curso da Saúde Pública, de especialização, vi o que tinha de mestrado e falei - ah, vou tentar ... -. Aí eu queria muito entrar lá, muito, muito ... muito. Eu fui para lá fiz inscrição ... e eu falava - ah, não, aqui eu tenho que estudar, tenho que estudar ... -, eu já me via lá. Foi muito engraçado.

$P$ : e você não pensou em fazer especialização, pensou em fazer mestrado direto ...

$R$ : é, pensei ... porque a especialização ia ser mais puxado que o mestrado, porque especialização é um ano, se não me engano é um ano ... aí era todo dia ... o ano inteiro. Ai eu pensei, se é para puxar, se eu entrar no mestrado direto, aí eu já puxo de uma vez, né ... aí eu fui e pensei em prestar o mestrado e não a especialização.

Essa aluna é graduada há poucos anos e ao relatar sua aproximação com a saúde pública valorizava a possibilidade de aplicação do conhecimento de sua área de graduação no campo da saúde pública.

(10A) ... fiz ciências sociais na graduação, na verdade queria fazer letras, mas entrei em ciências sociais, fui ficando ... Fui ver um pouquinho de 
letras e não gostei ... gostei mais das sociais e fiquei na UNICAMP, fiz UNICAMP e me formei em 87. Mas aí ... eu tinha um negócio com as ciências sociais assim ... que eu sou bem prática e eu queria saber 0 que eu faço com isso. Eu não gosto muito desse negocio de sociologia que fica a negritude do negro, a branquitude ... sabe ... falar enrolado assim ... esse "sociologuês", eu não gosto muito (...). E eu ficava intrigada com isso de - ah ... os trabalhos que são feitos -, o que é feito mesmo? Fica só na biblioteca?, não fica? Então, quando me formei, na UNICAMP tem núcleos de estudos, então tinha um núcleo de estudos de população, NEPO, e eles pegaram estagiários com bolsa do $C N P q$, de aperfeiçoamento. E eu fui lá fazer um estágio. O NEPO é basicamente demografia, e eu acabei indo para um projeto de saúde, mortalidade infantil, que tinha lá. Fiz entrevistas ... e eu gostei da área de saúde. Porque eu vi uma perspectiva assim - olha, vamos fazer uma pesquisa ... -, mas não é para ficar lá só engavetada ...

Um aluno deste segundo grupo se reconhece como um técnico, uma pessoa prática se diferenciando do grupo anterior definido por ele como sonhador e de pouca ação.

(9A) ... isso em off... acho que quase todo técnico tem esse... acho que é até um preconceito, mas... a gente acha que a média dos alunos lá da Saúde Pública é meio sonhadora assim... muito... planeja demais... tem muito planejamento e pouca ação... então os trabalhos em grupo a gente vê essa dificuldade sabe... é uma dificuldade mesmo. Então, tinha uns trabalhos em grupo com... tinha um grupo lá de 12 alunos, acho que metodologia, então o que a gente fazia de reunião para a coisa andar era difícil. Então, no final eram três... quatro pessoas que... que acabam fazendo... vai no computador... termina (...) e eu não tinha muito tempo (...) a discussão era boa... acalorada e tal... mas o trabalho prático, final... avançava um pouco.

Trazem necessidades de qualificação nascidas de situações concretas de trabalho, são alunos cuja instituição de origem tem interesse em que eles façam a pós-graduação, e que até os liberam parcialmente para cumprir os créditos; apesar da decisão ser exclusiva do pós-graduando, não havendo programação institucional para evolução em carreira, com mudança de atribuições após a conclusão do mestrado ou mesmo doutorado.

O trecho de depoimento apresentado a seguir elucida a rede de motivos pessoais e institucionais que cercam a decisão de fazer a pós-graduação, em casos como esses:

(4A) Então, de certa forma juntou um pouco as coisas, a possibilidade de acesso, assim ... de acesso que eu digo é da proximidade ... e também a vinculação que nós temos com a saúde pública (...). e também tem 
algumas coisas novas que seria interessante fazer para o próprio trabalho do SEADE. O trabalho na área de mortalidade, estatísticas vitais, tem um pessoal muito vinculado à gente aqui, né ... tem um pessoal da demografia ...

(...) Olha, é mais uma coisa pessoal. O SEADE na verdade em nenhum momento eles falaram - olha, você tem que ir porque se você não tiver 0 mestrado ... se você não tiver o doutorado ... - A partir de um determinado momento, passou a ser importante para o SEADE ter doutores sem mesmo que eles incentivem. Porque durante muito tempo foi assim: o SEADE era um órgão vinculado ao serviço público, o orçamento do SEADE, digamos assim, eram 10 milhões, o governo vinha e falava seu orçamento é 10 milhões. A partir do novo governo a situação modificou, nós perdemos muita gente, eles cortaram a verba do SEADE e a linha atual do governo é assim - olha, o orçamento é tanto, se vocês quiserem mais, vocês saem à caça, vocês vão buscar -. E é o que o SEADE tem feito, procurado assinar convênios com outras entidades e muitas vezes para assinar esses convênios as pessoas que bancam os projetos precisam ter doutorado. Só que em nenhum momento $O$ SEADE deu incentivo a esses doutores, as pessoas que nós mandamos fazer o doutorado fora, quando voltaram foram embora, às vezes nem voltaram ao SEADE porque nem tinha essa amarração. Como o SEADE libera sem salário, então não há essa obrigação, então as pessoas foram, $e$ antes de voltar começaram a receber propostas de outras entidades e aí foram embora, em geral nem voltaram para o SEADE e se voltaram ficaram um tempo e foram embora.

Agora, isso está complicando porque agora em nível de FAPESP, se o $S E A D E$ quer pedir um projeto à FAPESP, ele tem que ter doutor ... e o $S E A D E$ praticamente não tem doutores.... você pede um projeto ao $C N P q$ que significa verba. O CNPq exige para algumas coisas doutores (...). Além do mais os poucos doutores que nós temos já estão encabeçando projetos, então ... tem que buscar muito convênio com SABESP, CETESB, entidades que não exigem essa vinculação de doutor Secretaria da Educação. São projetos técnicos. O SEADE tem feito esses projetos mas os outros projetos mais acadêmicos ele não tem como fazer atualmente, nesse momento. Tem muitas pessoas encaminhadas para 0 doutorado agora, né ... mas nesse momento não tem. E em nenhum momento ele pediu, e nem incentivou. $E$ até por outro lado acho que a coisa ficou até mais complicada, porque as pessoas que pediram afastamento para fazer o curso lá no exterior, quando estão voltando agora ainda tem que negociar a volta ao trabalho (...) é ... Por exemplo, a pessoa que está lá, tem doutorado, não significa nada para a instituição, não há nem um aumento automático, nem uma reclassificação de cargos ... Então, às vezes muitas pessoas que estão lá, às vezes ficam desmotivadas.

\section{Saúde pública: iniciando carreira docente}

Entrevistamos uma aluna recém formada em nutrição que tem, no desejo de ser docente e fazer pesquisa, o motivo para estar cursando o mestrado. Está 
procurando iniciar-se profissionalmente. Traz um conjunto de experiências e motivações bastante distintas das apresentadas até este momento pelos outros grupos de alunos identificados.

(8A ) ... sou formada há pouco tempo, me formei em 94. Então, eu queria ... sempre quis seguir a área de docência, de pesquisa e de ensino. E na graduação eu fiz iniciação científica, fiz monitoria, então assim ... eu já tinha todo um direcionamento do que seria um trabalho posterior, né. E ... então, só que meu trabalho na graduação foi mais um trabalho na área de ciência básica, com experimentos em ratos ... que não deixava de ter um enfoque um pouco voltado para a saúde pública, porque eu trabalhava com a questão da desnutrição, alimentos alternativos, já prevendo um pouco assim, políticas de alimentação .... seria merenda escolar ... nessas áreas, né.

Mas eu vim para São Paulo para fazer a prova ... só que eu fiz lá na Farmácia, na área de nutrição experimental. E não passei (...) mas depois eu peguei e fiz prova para aprimoramento, especialização aqui no Hospital das Clínicas, né, na área de nutrição hospitalar, que não era a área que eu tinha feito iniciação científica, mas que era uma área que eu gostava, né. E em 95 eu fiz o aprimoramento no H.C, que é uma residência, de dedicação exclusiva ... e que lá também desenvolve pesquisa e tal. (...) E aí ... eu resolvi fazer a seleção, como estava aqui do lado, da Saúde Pública, e lá dentro do H.C eu resolvi que eu queria trabalhar com humanos e não com ... com ratos (...) e nunca tinha visto aqui na Saúde Pública ... porque eu estava com um enfoque mais da questão básica, da área experimental ... curso de nutrição ser aqui ... esse enfoque mais experimental é dado na Farmácia. (...) aí eu mudei, de não fazer mais na Farmácia e fazer na Saúde Pública, por querer trabalhar com humanos, né. E por não ter um programa de pós graduação em nutrição, né, e o que tem não ser de boa avaliação. E como o departamento está inserido dentro do programa de saúde pública, apesar de ter linhas de pesquisa que não são necessariamente de saúde pública, até que meu trabalho tem enfoque de saúde pública ... acaba tendo, né, que é a questão da epidemiologia clínica, né.

Se considerarmos o caminho definido pela FSP expresso nos pré-requisitos para inscrição e no processo seletivo para a pós-graduação, até 1990, (Anexo 5) podemos afirmar que o perfil do aluno era mais homogêneo até essa época, uma vez que o próprio processo dificultava a entrada de alunos com outras trajetórias profissionais e acadêmicas.

A partir dessa época, além das mudanças estruturais na pós-graduação da FSP, outras alterações se intensificaram e provocaram mudanças nesse perfil. 
Provavelmente a mais significativa seja a própria mudança na formulação e condução das políticas de saúde no país e os seus conseqüentes desdobramentos na organização dos serviços de saúde nos níveis municipais e estaduais (VASCONCELLOS e NARVAI, 1997). Estas mudanças já foram, como apontamos anteriormente, consideradas uma das questões que envolvem a problemática da especialização em saúde pública na FSP.

Sem entrar a fundo na questão, podemos dizer que houve também mudanças na oferta e demanda de emprego no setor saúde ${ }^{30}$.

Outro fator são as dificuldades de financiamento externo para o desenvolvimento de pesquisa no setor público.

Os depoimentos de dois professores ilustram bem o quadro de mudança de perfil dos alunos.

(2P) R: o tipo de aluno é outro, é outro (...) hoje você tem muito recém formado na pós graduação, e associado ao fato que está acontecendo, que é um fato também que precisa se levar em conta, né, que antigamente dada a estrutura de prestação de serviços do país, dada a importância que tinha naquela época o curso de especialização da faculdade, tá certo, a grande demanda que existia era para o curso de especialização. Como eu falei, até internacional, no Brasil todo e tal. Então, a clientela da pós graduação era uma clientela, que como pré requisito inclusive era o curso de especialização, era uma clientela que estava realmente mal ou bem, aí tem que analisar, ela vinha com outra perspectiva de interesse. Estou falando na média, né ... não estou dizendo casos específicos, mas na média. Por que? Porque a formação básica em saúde pública, uma titulação básica em saúde pública, que era reconhecida como tal pelo curso de especialização, ela já tinha. Então, a pessoa não vinha atrás de uma titulação apenas em saúde pública, mas vinha através, vinha também, lógico, o mestrado, mas vinha através de uma complementação mesmo. Eu acho que existia então uma clientela diferente. Uma das diferenças era a própria base de formação e conhecimentos em saúde pública que a clientela anterior tinha. Que hoje você pega ... e aí o que aconteceu? O curso de especialização ia mudando, mudou a realidade do país, outros centros começaram a ser colocados no país todo, a reforma na construção do país, a própria dinâmica das novas demandas em saúde pública, essa coisa toda ... colocaram que essa capacitação básica, digamos genérica, etc, ela está sendo oferecida ... multiplicaram-se os centros de formação no Brasil e mesmo internacionalmente, então a clientela aqui, digamos

30 ver: MACHADO MH et allii (1996); MÉDICI AC, NOGUEIRA RP MACHADO MH, GIRARDI SM (1992); e SANTANA JP, coordenador (1994) 
assim, mudou. Não há necessidade de fazer, fazem em outros lugares, de um lado. De outro lado, como a Faculdade aboliu o critério de pré requisito, de ter curso de especialização em saúde pública, então uma das características da clientela é ser recém formado (...). Outra característica é muita gente de serviço, ainda aumentou a nível de serviço. E gente que ... pode até não ser recém formado ... mas não está em serviço, no sentido de serviço de saúde pública, se a gente pode ... apenas para efeitos de raciocínio ...

(...) tem muita gente na pós graduação, que por exemplo ... é pessoa que está ... nas diversas profissões, tem uma atividade privada e vem fazer o curso de pós graduação. Porque ela quer ter ... até mesmo a gente conversando durante o curso, ela quer ter uma formação em saúde pública, quer ter o título de mestre em saúde pública, mas não naquele significado maior que seria ser mestre de saúde pública, no sentido que é um mestrado ... do que é uma pós graduação senso estrito.

Bom ... por isso inclusive que a Faculdade está nesse processo de revisão, né, quer dizer, talvez seja da própria função, papel do que ela começa a oferecer em termos de cursos básicos de especialização ... está aí na ordem do dia a discussão se a faculdade deve permanecer com seu curso de especialização ... ou não, ou se ficam essas ofertas todas de um lado. E de outro lado rever a própria pós graduação desde o ponto de vista de estrutura, de conteúdo, de objetivos, de clientela ... etc ... Até está sendo rediscutido o processo de pré requisito ou não, outros títulos, etc ... etc. Bom ...essa é uma linha, né (...) existe uma questão ali: que direcionalidade deve ter uma pós graduação? Está certo?

A entrevista com professores da área de saúde ambiental mostra também haver mudança, com a procura pelo curso de pessoas da área empresarial, o que não foi referido dessa forma por professores das outras áreas.

(4P) ... Na engenharia sanitária latino-americana ... esta escola é a mais antiga que existe. Nós formamos o primeiro engenheiro sanitarista brasileiro, foi na antiga Faculdade de Higiene. Mas ... eu me lembro quando fiz o curso aqui da Faculdade, há muitas décadas atrás, a metade dos alunos eram formados por colegas latino-americanos ou da África Portuguesa. Os que eram brasileiros eram funcionários do Ministério da Saúde, né. E hoje não, hoje esse quadro mudou bastante. Você tem uma predominância grande entre alunos e profissionais interessados na área realmente quase que empresarial. Seja empresa estatal, de saneamento, seja uma empresa privada, industrial, mudou, ... mudou bastante.

\section{A Escolha Institucional}

A Faculdade está situada em um polo de atração para a pós-graduação.

A USP é a universidade brasileira que mais forma especialistas, mestres e doutores 
no país. Os alunos apresentam um conjunto de argumentos que justifica a procura da FSP para a realização da pós-graduação.

Para o primeiro grupo de alunos um dos motivos diz respeito à tradição da Faculdade, dela ser o espaço do sanitarista.

(7A) ... tinha que ser aqui na Faculdade de Saúde Pública. Acho que pela história daqui ... essa coisa da historia é muito forte para mim. Da tradição, enfim ...

(5A) Bom ... sanitarista tem que ir para a saúde pública ... não tem ... Poderia ter feito na medicina preventiva também ... né ... mas eu achei que, na época, eu fiquei pensando que a saúde pública, por toda a minha condição de médica sanitarista, por ter feito o curso de especialização em saúde pública ... lá ... eu achava que talvez a saúde pública tivesse mais a ver com o meu perfil de trabalhadora de serviço de saúde. Não quero ser filósofa, não quero ser uma grande pensadora a respeito ... estava pensando mesmo de aprimorar os meus conhecimentos, fazer uma reflexão da minha prática e poder voltar meu trabalho para a prática. Então, achei que a saúde pública talvez tivesse mais próxima disso, né, a minha impressão era essa ... que ia lidar mais com as coisas que são próprias dos serviços. Eu achei que ... pode ser uma coisa errada ... uma sensação que ... uma percepção ... pode ser uma percepção equivocada mas eu acho que a preventiva está mais distanciada dessa coisa do trabalho, está mais preocupada com formulação de conceitos, de propostas ... mas mais distanciada dessa coisa do fazer ...

$P:$ e a outra opção seria sair de São Paulo, né ...

$R$ : exatamente, que para mim não tinha viabilidade ...

Então, eu fui para a saúde pública.

A intenção de ser orientado por um determinado pesquisador de renome na área foi também apontada como motivo.

(6A.) ... assim ... vir para a USP, se eu não pudesse ser orientada pelo $C$. ou pela $M$. H., que são a dupla ... assim ... "tico e teco"... que fazem as coisas com as quais eu me identifico ... eu não viria ... né. Porque, eu tinha uma experiência muito interessante no mestrado da ENSP, uma instituição bastante arejada, com propostas bastante interessantes de trabalho, mas com a área de nutrição ainda muito incipiente. E para vir para cá, para trabalhar com uma pessoa que não tivesse ... não valia nem a pena para mim ... porque é um ônus muito grande ... Tem uma vantagem muito grande você sair da sua cidade, você conhecer outras instituições, conhecer outras pessoas, eu fiz contatos super interessantes, amizades super interessantes, mas tem um ônus você conseguir dispensa do trabalho, você fica longe do marido ... eu ficava a semana inteira aqui ... 
... E foi muito importante ele ter se disposto a me orientar porque talvez se ele não tivesse se disposto talvez eu não viesse, porque assim ... para mim está sendo .. o doutorado na USP ... para mim ... é o doutorado sendo orientada pelo C.. Isso que significa para mim ...

Enquanto para alguns o fato de já conhecer a Faculdade, já ter tido algum contato ou trabalho conjunto é uma razão, para outros justamente ao contrário, eles buscam diversificar sua experiência. Esta última perspectiva foi trazida pelos entrevistadores mais jovens.

(1A) E por que nessa Faculdade ... Porque eu trabalhava na região metropolitana de São Paulo, numa unidade de saúde (...) e houve a possibilidade então dessa aproximação com a Faculdade aqui, comecei aqui, conheci a escola ... lá no cotidiano do meu trabalho em C., a Faculdade de Saúde Pública e a Santa Casa,... lá também era campo de estágio da Santa Casa ... e era onde os residentes de medicina geral comunitária faziam o trabalho de campo.

Então, nesse convívio com Santa Casa e com Saúde Pública, eu fui apresentado a essas instituições através de alunos ou professores dessas instituições que passaram por C., né.

(10A) ... e eu queria sair da UNICAMP ... Eu fiz graduação aqui - ah, eu vou fazer mestrado aqui?, não ... quero ver gente nova, ver gente diferente, que pensa um pouco diferente -, porque você fica num lugar você fica ... com manias, vamos dizer, do lugar que você está. Então, eu queria algo diferente. Queria encontrar gente ... ah ... queria fazer outra coisa, não o que estou fazendo, não o que estou vivendo, para trocar mesmo. Eu acho legal isso. Eu tenho uma amiga que fez mestrado, fez graduação, fez mestrado e está fazendo doutorado ... Eu falo para ela sai daí! ... -, você conhece os professores todos ... Então eu falei - vamos mudar -, muda, sai, vai para outro lugar, por isso que eu queria sair.

(6A) ... mas eu achei que era dose demais fazer residência, mestrado e doutorado na mesma instituição. Achava que no mestrado já tinha conhecido as pessoas, na residência, sabia a quem procurar ... no que eu precisasse ... e que essa experiência de sair do estado era bem interessante.

Outra razão está no fato da FSP ficar em São Paulo. Os alunos de fora sentem-se atraídos pelos recursos da cidade, e os alunos que residem ou trabalham em São Paulo, por motivos de serviço ou pessoais, teriam dificuldades de se deslocar para outra região, mesmo porque não apresentavam possibilidade de serem totalmente liberados para fazer o curso. 
(8A) quando você veio de Goiás, você se decidiu primeiro pelo estado ou pela escola? ... eu decidi o estado ... é, eu queria São Paulo ...

(4A) E tinha três possibilidades, uma era voltar para o CEDEPLAR, onde já tinha feito o curso, outra seria fazer em Campinas e a outra seria fazer aqui (...) Ai existia uma outra alternativa que era ir para o exterior, mas eu não tinha motivação para ir ao exterior.(...) Aí olhando também as matérias, optei por fazer saúde pública, que de certa forma facilitava um pouco a vida, né (...) Então, de certa forma juntou um pouco as coisas, a possibilidade de acesso, assim ... de acesso que eu digo é da proximidade ...

(2A) ... exatamente naquela baixa do entusiasmo, por todo um retrocesso que houve mesmo, né, nesse momento eu dei uma saída do país e eu fui até com a intenção de encontrar um centro onde eu fizesse o doutorado. $E$ eu pensava ir para Inglaterra ou para os EUA ... E ... mas tinha uma certa, como é que eu vou te dizer, não é atração, uma certa curiosidade por São Paulo, porque eu sempre gostei de São Paulo, desde que eu conheço São Paulo que eu gosto de São Paulo ... que tem a ver uma coisa assim de cidade muito grande, eu adoro cidade muito grande ... tenho uma sedução ... morei em New York, adorei New York ... fiquei lá um tempo me preparando para fazer o doutorado ... (...) E aí essa noite eu falei - ah, eu vou tomar a minha decisão quando eu chegar no Brasil ... porque eu acho que vou fazer o meu doutorado em São Paulo. Vou estar mais próxima de tudo, né, das minhas coisas, da minha casa ... é minha língua ... vai ser muito mais fácil eu trabalhar com a minha língua ... vai ser mais fácil eu encontrar esse objeto, porque eu quero estudar esse objeto como ele é ... lá no Brasil

A aluna estrangeira, em seu país não tem oferta de curso de pósgraduação, e por referência de um amigo escolheu a FSP, ela destaca a importância dos recursos institucionais.

(3A) ... A saúde pública no meu país é pouco institucional, não tem o caráter que tem aqui no Brasil ... é uma coisa que está se institucionalizando, está se organizando ... então tem essas características ... Então, lá você não tem orientador para tese, não existe ... você trabalha sozinha ... você trabalha o tema que você considera e você procura seus próprios recursos ... mas não tem recursos disponíveis para nada, lá não tinha nem referencial e nem orientação ... Por isso que eu decidi vir para cá ... Claro, tinha uma pessoa que veio primeiro aqui, que é o M., né ... ele é dominicano e ele deu referências, que era boa ... que valia a pena ... pelo menos a gente tem essa coisa que não tinha lá (...)

porque na verdade eu queria ir para EUA, mas não tenho bolsa para EUA ... não há bolsa para saúde pública para Latinoamérica ... retiraram ... tem outras bolsas, mas para saúde pública foi retirada ... os EUA ... 
Aí ela veio e falou para mim - olha, a saúde pública lá não é que seja uma maravilha ... mas você tem possibilidades de fazer o que você quiser ... pelo menos em termos de biblioteca, em termos de contatos com professores em determinadas linhas ... contato com outros pessoas ... -, então aí eu me encantei com a idéia e eu vim ...

Eu estou procurando me desenvolver justamente na área de saúde pública, porque no meu país está muito restrito ...

Apenas uma aluna se referiu ao conceito CAPES como um dos critérios para a sua escolha, aluna recém formada que espera fazer a pós-graduação para iniciar carreira docente.

Mesmo não tendo aparecido na fala dos sujeitos como um dos motivos a bolsa de estudos, não devemos abandonar este motivo. O Programa de Incentivo à Capacitação Docente (PICD) da CAPES tem por exigência que o aluno/docente curse a pós-graduação fora de sua localidade de trabalho. 


\subsection{PROFESSORES}

\section{Assumindo um novo papel}

Os professores têm trajetórias em alguns pontos semelhantes aos grupos de alunos. A passagem para a saúde pública, no caso dos professores, é marcada pelo exercício de alguma forma de prática em saúde pública e pela formação em nível de pós-graduação sensu lato. A maioria (64\%) dos orientadores da FSP se doutorou na própria Faculdade e iniciou sua formação na época em que as normas da pós-graduação da FSP exigiam a especialização como pré-requisito para fazer a pós-graduação e a experiência profissional em saúde pública para fazer a especialização.

Mas como se dá a passagem para o papel de professor? Para responder a essa questão vamos em primeiro lugar procurar responder como se dá a introdução dos professores na Faculdade.

Segundo WANDERLEY (1984) na universidade brasileira "Durante algum tempo prevaleceu a prática de admitir professores através da cooptação, normalmente feita pela escolha de alunos que se destacavam em seu aprendizado ou que se afinavam mais com as idéias e o jeito do professor, e que exerciam o papel de auxiliares, de monitores. (...) A regra hoje, com raras exceções, é no sentido de que um professor seja escolhido por concurso, usualmente aberto por um Departamento, com exigência de títulos e provas".

$\mathrm{Na}$ Faculdade a aproximação se dá também a partir de convites de professores para alunos ou para voluntários auxiliares de pesquisa, mas principalmente convites para profissionais de serviços de saúde, parecendo que uma condição necessária, talvez não suficiente, é a de ser bom profissional.

(7P) (...) ele me disse que primeiro deveria fazer o curso de entomologia, antes de fazer o mestrado. Então, eu vim para cá em 70 , para fazer o curso de entomologia. E quando cheguei em 70 ele me convidou para ficar aqui. Então, em 72 eu me desliguei do Museu Goeldi definitivamente e fiquei aqui só ... já para trabalhar com entomologia.

(6P) ... me formei e fui para o Hospital E. (...) Minha formação é em obstetrícia, então entrei lá para dirigir a parte do centro cirúrgico, centro obstétrico (...) eu desenhei o centro cirúrgico e a terapia intensiva que é 
até hoje no E., né. E já tinha feito manuais, tudo, e eles queriam que eu voltasse para o centro cirúrgico e não para o centro obstétrico. Mas aí eu já estava cansada. E aí eu vim para cá.(como voluntária) $\mathrm{O} \operatorname{Dr}$ C. me acolheu pela minha formação.

(2P) ... eu iniciei o meu trabalho como docente da Faculdade, ainda como professor da Faculdade de Medicina de A, no Departamento de Medicina Preventiva, quando eu já estava em São Paulo trabalhando na Secretaria de Saúde do Estado. Isso foi em 1975. (...)

O professor $R$. R. me convidou para assumir duas disciplinas que ele dava, em 76 eu entrei formalmente para a faculdade, por concurso e continuei tocando isso. (...) Comecei também em termos de orientação, comecei o meu trabalho de orientação com os alunos, né ... e dado que eu vinha de serviço e dado também que a faculdade estava num processo de ... já tinha formado muita gente e tal, então eu iniciei como orientação uma coisa muito ligada a pessoal de serviço. O pessoal de serviço. Tirando logicamente algumas exceções, não exceção, mas o que mais tinha era gente de serviço, né, em termos de trabalho, né.

O convite pode ser viabilizado por um trabalho voluntário ou por meio de comissionamento de um outro órgão público para a Faculdade.

Esta estratégia é ainda hoje muito usada na FSP, geralmente existe o interesse dos dois lados, a pessoa interessada em ser comissionada tem a possibilidade de estar liberada do serviço para fazer a pós-graduação e adquire experiência de trabalho na Universidade e o professor que faz o convite tem mais um colaborador. São situações também associadas ao momento político do serviço de saúde, podendo às vezes representar um "refúgio" para o comissionado.

(8P) Eu vim fazer um curso aqui ... eu vim fazer uma disciplina de pós com $R$. B. ... E ali naquele momento estava definindo o tema de pesquisa que era a eficácia da vacina BCG. $E$ aí nas conversas com o R. ele falou estou com um projeto nessa área ... do Ministério, você não gostaria de vir trabalhar comigo?, para a gente tocar esse projeto? - você toca a fase de campo... Bom ... crise na coordenadoria ... então por que não vir para cá ... Então, vim para cá, então foi o meu primeiro contato com ... de trabalho junto à Faculdade de saúde pública ... né ... sendo colocado à disposição da Secretaria, pela Secretaria eu fui colocado a disposição da faculdade de saúde pública para este projeto. Bom, este projeto levou um período aí de um ano e meio mais ou menos ... um ano e meio eu acho ... e fiquei vinculado ao $B$. ....) Aí terminado o projeto voltei para o centro de saúde (...) Aí depois desses anos teve uma história de escolha de cargo de médico sanitarista, e aí eu escolhi o instituto de saúde (...) aí teve um outro momento em que fiquei comissionado, me comissionei no Departamento (...) aquele período inicial, e depois aproximação com pessoas da Faculdade, do departamento de epidemiologia e aí indicaram meu nome para trabalhar aqui ... me colocando a disposição ... já estava 
no doutorado. (...) foi aí que eu comecei a ter uma aproximação maior com a estrutura, com as pessoas ... o cotidiano mesmo da faculdade ...

(...) no final de 94, eu tomo a decisão de não ficar mais a disposição da Faculdade ... por conta de ... já tinha terminado o doutorado (...) aquela situação de ficar a disposição, não via perspectivas de ter uma vaga para contratação. Aí considerei algumas possibilidades que apareceram, então eu pedi o meu descomissionamento (...) o pós doutorado ... se viabilizou e acabei indo em 95. Aí quando estou lá abre-se uma vaga ... aí fiz concurso, aí voltei.

Nos depoimentos, os orientadores não apresentam a carreira de professor como uma meta inicial de sua trajetória profissional, ao contrário parece que isto vai acontecendo sem ser percebido. Falam que queriam estar na FSP, vão chegando por convite de um outro professor e começam a "ajudar" em projetos de pesquisa, ou mesmo dando aulas, mas não como responsáveis por uma disciplina ou por um programa didático.

(8P) ... bom ... nunca pensei em ser professor universitário, isso foi uma coisa que realmente foi surgindo, nunca parei para pensar como que

Um dos critérios estabelecidos por nós para a escolha dos professores a serem entrevistados foi o de chamar orientadores que consideramos possuir uma aproximação maior com pesquisa e outros maior com extensão. Naturalmente todos desenvolvem atividades de ensino, pesquisa e extensão, porém como em outras áreas alguns professores intensificam mais uma ou outra atividade.

Durante as entrevistas os professores apresentaram sua experiência de estar executando ou ter executado práticas sanitárias como parte de sua trajetória. Fase bastante valorizada por eles, envolvendo nos depoimentos um relato mais detalhado sobre o desenvolvimento dessa prática do que sobre o da sua carreira como professor.

Uma aluna, docente de universidade federal, expressa sua relação com serviço da seguinte forma:

(2A) ... e antes de terminar o mestrado, eu entrei na universidade, como professora. E daí eu fiquei, esse tempo que eu te falei, né, 12 anos ... E era difícil sair da Secretaria de Saúde, pela questão da prática, né, quer dizer, aquele contato com a realidade ... apesar de todas as limitações ... mas era uma coisa que eu digo que "serviço é cachaça"... assim ... 
quem trabalha em serviços, e tem uma inserção na universidade, ao meu ver, é muito difícil deixar os serviços, porque você tem uma oportunidade muito importante de trabalho ... quer dizer ... você articular uma coisa com a outra ... e no meu caso, a disciplina ..

A partir da prática profissional sentem-se habilitados para ensinar saúde pública, ou porque passam a ter experiência, domínio da linguagem da área, ou ainda compreensão da dimensão da saúde pública. Isto acontece mesmo para os professores que vieram para a Faculdade depois de terem sido professores em outra universidade e para aqueles que também possuíam experiências em pesquisa. O ato de ensinar está associado à "troca de experiências" e a "ensinar o que sabe fazer".

(1P) ... bom quando eu entrei aqui ... eu ainda estava fazendo doutorado ... foi em 1978 ... e eu tinha tido experiência de trabalho na Secretaria de Saúde, mas a nível de gabinete, tinha um programa de nutrição, então foi muito interessante porque eu tive a experiência de estar muito próxima do Secretário de Saúde que era o Doutor Leser (...) aí eu acho assim ... o seguinte: começar a ser orientador, assim ... o interessante é que aí você começa a ter oportunidade de estar passando para pessoas jovens, na verdade não é passando experiência, é trocando experiências (...), as experiências que eu tive, assim ... de estar trabalhando junto a projetos de pesquisa que faziam diagnósticos do problema, quantificando os problemas ... vendo determinantes. A história de também ter trabalhado com programas de intervenção, né, programas de nutrição, e de ter avaliado impacto desses programas a nível de pesquisa.

Então, assim ... o que acontece é que você acaba assim, eu acho ... gostando em geral ... que as pessoas gostam do tema que escolhem, gostam muito, e aí se torna prazeroso, muito prazeroso ter a oportunidade de iniciar outras pessoas no percurso que você já tem alguma quilometragem, né. (...). Então, isso ... você ter experiência prática juntando também daí com a experiência acadêmica, dos cursos que eu fiz aqui na USP e tal ... Aí passa a ser estimulante, é uma conseqüência você se inserir num curso de pós graduação como orientadora. Porque daí você imagina - bom, alguma coisa já tenho de experiência, sou capaz de ... -, e aí você passar a motivar pessoas ... as pessoas já estão até bem motivadas. E outra coisa bem importante que eu acho: sempre estar se relacionando com um grupo de pesquisa, estar se relacionando com outras pessoas, não ficar isolado, né. $E$ assim ... ter seus próprios alunos também se articulando em projetos maiores. Então, aí é uma experiência gratificante

(5P) ... como professor ... eu comecei dando aula em cursinho, quando entrei na faculdade, então ... eu já fui professor de português, de literatura, mas mais de literatura ... Eu dei ... acho que durante 4 anos eu 
dei aula de literatura em pré vestibular e curso de madureza, né. Depois dei aula de história, geografia, de OSPB, de educação moral e cívica ... de estudos sociais ... quer dizer, todas essas coisas.

Aí depois comecei a dar aula em cursos na São Camilo ... antes de vir aqui para a Faculdade, então se somar isso aí ... são ... tem 24 anos ... com mais um ano já daria para aposentar pela proporcional ...

$P$ : mas a sua aproximação com a saúde, foi como?

R: a minha aproximação com a saúde foi há 17 anos atrás ... foi um concurso na Secretaria da Saúde. (...) foi muito importante, para entender a saúde e para ... foi o trabalho na Secretaria da Saúde e principalmente na vigilância epidemiológica, né. $E$ com vigilância epidemiológica, porque aí éramos dois sociólogos, e um estatístico, e aí a gente acabou fazendo duas coisas que era um projeto que estava se fazendo na vigilância, no Estado ... foi pesquisa em torno dos surtos. Então, eu comecei trabalhando em pesquisa com surto de febre tifóide (...) Então, foi um início de vislumbrar um trabalho de pesquisa em cima da vigilância epidemiológica. E a gente acabou fazendo muito ... trabalhando com pesquisa, um pouco com treinamento, eu fui trabalhar um pouco na CSC, foi no último ano, com o planejamento no nível central (...). Então, foi muito importante a experiência na Secretaria da Saúde ... eu digo importante também por ter entrado no nível central, entrado no nível técnico ... e aí começar a olhar essas questões, quer dizer, pela formação acho que teve esse viés de entrada aí, eu entrei por aí. Tem gente que entra por outros caminhos, quer dizer, eu estou falando no meu caso que é ... digamos ... uma formação não da área da saúde estrito senso, né, dá para participar da saúde mas não estrito senso, então a experiência veio através do meu ingresso na Secretaria.

Não é a única trajetória, mas no meu caso foi uma trajetória que deu essa oportunidade de olhar de uma maneira bem ampla ... ... isso foi muito importante para eu dar aula, porque eu não sabia tudo, mas alguma coisa eu sabia .... estava bem situado ... Entender a história do tétano, da febre tifóide, ou então do sarampo, quer dizer, comecei a apreender um pouco desse conhecimento do biológico a partir do tema, da doença, dentro da vigilância.

(...) era outra coisa entrar em sala de aula ... com essa carga, quer dizer, de repente alguém levantava alguma coisa e falava - olha, se isso e isso acontecesse ... -, então eu tinha um referencial. Não era muito sistemático, ele era em alguns planos mais superficial, mas ele dava conta de entender minimamente como algumas coisas funcionavam por aí. E aí ter um pouco de ... acho que isso ... peguei muito uma época na década de 80 de discussão, né, quer dizer, do PREVSAÚDE, quer dizer, comecei a me envolver, participar da ... e assistir mesas da discussão da reforma do sistema de saúde, então isso me deu, começou a me dar uma base geral a respeito do campo da saúde pública. Acho que isso funcionou quase que como um pré requisito na minha formação, né. Então, eu diria que além da Secretaria de Saúde, os movimentos, as associações, né, a Associação Paulista de Saúde Pública na época estava discutindo o PREVSAÚDE. Outras associações, outros conselhos, quer dizer, na época a própria Associação dos Sociólogos participava desta discussão do PREVSAÚDE, quer dizer, tinha um grupo já 
tradicional a nível da Associação que fazia parceria com essas instituições, então essa participação, Secretaria e entidades civis, elas também funcionaram para ajudar um pouco na minha formação. Acho que isso é importante

Como o professor é recebido pela Faculdade, como ele é acompanhado em termos de preparo mais específico para ser um orientador? Observa-se tanto para os professores que iniciaram como auxiliar de ensino como os que já iniciam sua carreira na FSP como doutores, que o processo de aprendizagem para trabalhar como orientador é o de reproduzir a formação recebida.

Não se percebe nos depoimentos dos professores a existência de espaço institucional criado pelos próprios professores onde ocorram discussões sobre suas práticas educativas. Seria esperado numa instituição universitária que estas questões fluíssem mais rotineiramente. Todos passaram pelo processo de formação em nível de pós-graduação na FSP ou fora dela, por uma exigência da Universidade. Será que isto seria considerado suficiente?

A inexistência de uma política de capacitação de recursos humanos docentes na FSP pode ser percebida no Parecer da Comissão Permanente de Avaliação sobre o Departamento de Prática de Saúde Pública ${ }^{31}$ ao responder à seguinte questão:

"O departamento possui uma política de atuação a médio e a longo prazos, visando fortalecimento e/ou introdução de programas de metas de áreas de pesquisa, melhoria de ensino, captação de recursos, etc.?

O Departamento reconhece que não possui política de atuação a médio e longo prazos. Deve ser assinalado que cerca de $50 \%$ dos departamentos da USP, já analisados no processo de avaliação em curso, também não possuem política de atuação (Doc. De Avaliação Departamental, R. Meneghini, 1994)".

Um professor entrevistado assim relatou seu início nas atividades de docência:

(3P)Terminei a graduação em 73. Foi logo no final da graduação que eu já fui convidado para vir para cá. $E$ a idéia era vir para cá e montar a

31 USP. Comissão Permanente de Avaliação opus citado. 
disciplina de toxicologia dentro do curso de saúde pública. Então já fui dentro da graduação, fazendo a especialização em toxicologia ocupacional. E foi interessante porque já afunilei já no final da graduação. No semestre seguinte, eu já vim para cá para dar aula no curso de pós graduação. Então, a minha experiência de dar aula na pós graduação é algo bem estranho, porque eu nunca tinha sido aluno, não sabia direito nem o que era ... uma pós graduação e me colocaram numa sala de aula para dar aula. E eu não tinha condição nem de ser aluno ainda do curso de pós graduação porque não tinha feito especialização ainda. Então, no ano seguinte à formatura, eu fui fazer especialização .... em saúde pública ainda. Então, no primeiro ano ainda fiz saúde pública e depois no segundo ano de formado é que eu pude entrar no mestrado e aí que eu pude ser aluno de mim mesmo ... quer dizer, eu fui ser aluno da disciplina que eu dava aula no segundo ano. No primeiro ano não podia nem ser aluno ainda, embora fosse professor.

Então, é um negócio muito estranho, não que eu seja um magnata do saber ... que eu seja ... um ser super inteligente, etc ... é que simplesmente não tinha nenhum professor na época aqui que desse especialização em toxicologia e que estivesse interessado em saúde do trabalhador, por isso que eu acabei vindo para cá.

$E$ aí então comecei a desenvolver a disciplina que já existia, que era $o$ laboratório de higiene do trabalho. (...) Bom, aí a coisa foi evoluindo até que fiz o mestrado e o doutorado, aí então passei a ser orientador. Então, realmente passei a orientar alunos em ... a partir de 84. E aí passei pelo processo que os professores passam aqui na Faculdade, não na universidade, ou seja, nenhum processo, ou seja, você terminou o doutorado, recebeu um diploma, aí entra com um processinho na CPG e a CPG, baseada em alguns critérios, ou seja, os critérios estão sendo até revisados agora pela própria CPG, mas os critérios básicos são ter título de doutor, ter pesquisas na área, ter alguns trabalhos publicados, ter alguma experiência, alguma coisa ... que ainda é um pouco nebuloso $o$ que é necessário para ser orientador.

$\mathrm{Na}$ época, ainda em 84, praticamente não precisava nada. Precisava ter o título de doutor apenas. E preencher um questionariozinho extremamente simples. (...) então, eu posso a partir do dia que eu defendi a tese, orientar alguém para fazer exatamente aquilo que eu fiz ... que acabei de fazer. (...) Simplesmente o orientador é para orientar, óbvio ... só que ... o que significa isso ... Então, na prática eu tenho enfrentado uma porção de coisas assim que eu senti que na época eu acho que deveria ... no mínimo recomendarem um livro para a gente ler, alguma coisa ... darem algumas regras básicas do que faz o orientador.

Quando o aluno vem com uma dúvida técnica, quais são os critérios que eu tenho que utilizar para que aquela dissertação, aquela tese sigam? Isso para mim é uma dúvida muito grande ...

Então, muito mais em conversas de corredor, às vezes lendo uma coisinha aqui, lendo uma coisinha ali, a gente acaba formando uma idéia ... Então, para mim eu tenho bem claro como funciona, como eu oriento os alunos. Mas eu não tenho certeza que isso seja o pensamento da USP ou o pensamento da própria Faculdade. 
Um dos professores entrevistados, conviveu muitos anos com um professor catedrático (uma das funções do catedrático era a de iniciar no magistério novos professores). Ele iniciou sua carreira como auxiliar de ensino interessado principalmente em fazer pesquisa em sua área, definiu seu preparo de forma distinta do professor citado anteriormente.

(7P) ... e começar a ser orientador, você já se sentia preparado para isso? ... gozado, eu nunca pensei nisso ... eu estava vendo aí ... fazendo curriculum, fazendo memorial ... e depois também vendo os meus orientandos e vendo o sistema que é feito atualmente, então que o orientador tem que se preparar ... quer dizer, hoje em dia não deixam o mestrando, o mestre ... ser orientador de doutorado ... nem o doutor recente ser orientador de doutorando, né. E na minha época eu não tive nada disso. Não sei ... pelo fato talvez ... eu comecei já no Museu Goeldi como um bolsista do CNPq, eu já tinha alunos de orientação. Uma orientação ... hoje a gente chama de iniciação científica, pegando os alunos de graduação. Então a gente já tinha ... era o sistema nosso lá ... tranqüilo ... e todos nós bolsistas tínhamos 2 ... 3 alunos que a gente orientava permanentemente e " $n$ " alunos que (...) olha eu poderia ter pensado, mas nunca pensei ... é ... naquela época era um sistema dos próprios orientadores, dos próprios catedráticos, antigos, né, já treinando a gente para ir orientando outros indivíduos, né. Por exemplo, no museu era típico, tão pouca gente que se interessa por museu que quando aparece um, todo mundo está disponível ... a cuidar a criar etc. Então, eu tive muitos orientandos já no Museu Goeldi, alguns chegaram a ser até diretores do museu, etc ... e quando cheguei aqui já foi um negócio quase que ... passivo ... quer dizer, fui entrando, sempre tinha estagiários inicialmente ... sei lá ... nunca pensei nisso.

Não percebemos na FSP a utilização de monitores como uma forma de preparo do profissional para exercer a docência. Hoje a carreira docente na USP tem início com o cargo de professor doutor o que segundo um entrevistado, foi apontado como um aspecto que dificulta o entrosamento e o crescimento do professor nas atividades da FSP.

(6P) ... desde o começo trabalho com a pesquisa aliada ao ensino ... E é uma coisa assim ...do Dr. C. ter formado o pessoal assim, eu acho ... É o que eu sinto falta na incorporação dos novos docentes ... eles já chegam com a cabeça feita ... e eles não entram nisso ... então é mais difícil fazer pesquisa ... P: Mesmo entrando num grupo onde os docentes têm essa característica?

$R$ : ... não consegue absorver, a não ser que tenha passado ... e esse passar, a gente não tem mais tempo de passar ... você teria que estar passando para seu assistente, para alguém que trabalha junto com você 
... você já recebe o pessoal independente. Já na sua linha de pesquisas, e aí ele não absorve a linha ...

Nesse quadro podemos fazer duas afirmações sobre o processo de formação do professor na Faculdade - não tem suporte ou não recebe orientação no sentido de preparo e avaliação de seu trabalho como professor e, ao assumir seu novo papel, ele "não dá as costas para os serviços". Nenhum professor deixou de fazer referência a questões próprias da saúde pública, e de intervenção no campo, porém nem todos falaram de atividades de pesquisa.

Esta situação dá contornos próprios à forma de ser professor na FSP. Ela pode estar sendo reforçada no decorrer do trabalho como professor, seja pelo objeto da saúde pública, pela história profissional dos docentes, pelo tipo de aluno que a Faculdade recebe, ou ainda pela forte expectativa, tanto de professores como de alunos, para que a Faculdade interfira na elaboração e execução das políticas públicas de saúde. A articulação intrínseca da área com as políticas públicas e as práticas dos serviços, citada por MINAYO (1997), é evidente na fala do professor e do aluno.

(8P) P: e você como professor que relação tem com o serviço? Ou não você especificamente mas a Faculdade ...

$R$ : não, acho que a faculdade tem pouca ... pouca penetração com os serviços ... pouca interrelação ... as relações se dão mais com pessoas ...

Agora, eu particularmente tenho muita relação com o serviço ... sem considerar o fato das minhas duas alunas de pós graduação serem ligadas aos serviços ... possivelmente os dois que vão entrar, ou três ... também são de serviços ... Então, por aí já tem a primeira ligação. E também uma questão que se dá a nível de corpo docente, porque a grande maioria é ligada a serviços ... A questão da carreira acadêmica ela está se dando hoje, para nós, né, num momento um pouco posterior ... do que era uns anos atrás ... na percepção que eu tenho particularmente na nossa área ... na saúde pública ... está se dando um pouco mais tarde ... Uma questão de espaço mesmo. Agora, outras áreas não, outras áreas se dá de uma forma mais veloz ...

Bom ... mas o que estava te colocando é isso. Fora isso ... eu sou chamado freqüentemente para avaliar projetos de pesquisas operacionais, particularmente nessa área de saúde e trabalho, que é o enfoque que eu estou mais dirigido. Então, eu discuto com eles os projetos ... agora, são projetos pequenos, enfoques bem dirigidos para os resultados te permitirem um planejamento para desenvolver ações ... para cursos ... eu sou chamado para discutir o enfoque de epidemiologia na saúde do trabalhador ... 
Bom, agora estou envolvido com um projeto ... que é uma proposta de reformulação de Políticas e Práticas em Saúde do Trabalhador pelo Governo do Estado ...

(7P) ... e atividade de extensão ... quais são?... além dos estágios, que a gente dá muito estágio para fora, para as instituições ... recebendo pessoas é treinamento de pessoal Acho que isso aí é importantíssimo ... a gente não se nega, está sempre disponível e o pessoal da Fundação, antiga SUCAM eles consultam sempre a gente, a gente está sempre em contato com eles ... e sempre na idéia de preparar pessoal, formar pessoal. E a prova disso é o curso de entomologia que todo ano praticamente o nosso público é o pessoal enviado por eles.

$P$ : vem gente de fora de São Paulo ou não?

R: vem, sempre ... sempre. Agora mesmo ... acho que são 10 alunos ... tem uma só que é de São Paulo, os outros 9 são de fora. ... Então, a gente tem uma relação muito boa e acho que a gente tem uma produtividade interessante ... e está sempre recebendo gente, treinando gente e fazendo estágio, formando gente em cursos ... dando cursos fora (...) usa muito o laboratório, tem que usar muito a prática, prática de laboratório de campo.

É intensa a participação dos professores em atividades de extensão consultoria e assessoria - como já foi comentado no primeiro capítulo, o que deve trazer oportunidade dele se rever na estrutura do serviço e trazer relações interessantes para ele e para a escola. Isto talvez o deixe mais aproximado da prática de saúde pública do que da prática de professor.

Reforçando essa afirmação lembramos que não é raro um professor assumir cargos públicos no setor. A participação da FSP nessas atividades é vista com orgulho e valorizada pelo corpo docente.

(4P) $P:$... a sua experiência profissional além da docência?

$R$ : eu sou consultor. Eu estou em turno completo aqui na Universidade. Eu passei muitos anos trabalhando no governo, dirigindo uma empresa estatal na área de controle ambiental, e fui diretor de pesquisa dessa empresa. Uma atividade muito difícil de ser realizada pelo fato de ser uma empresa estatal querendo fazer pesquisa. Mas foi uma empresa que foi modelo latino-americano de gestão do meio ambiente, ainda é modelo. Com profissionais na sua maioria formados aqui. Eu por exemplo, nesta sala que nós estamos, essa empresa foi projetada. Então, a idéia, a concepção dela, saiu daqui (FSP). Só que a paternidade nossa não aparece, né.

Outro item do Parecer da Comissão de Avaliação do Departamento de Prática de Saúde Pública destaca o valor da prática profissional, e o reconhece 
como um departamento mais profissionalizante que acadêmico.

"Não se deveria esperar de docentes de departamentos profissionalizantes que publicassem elevado número de pesquisas em periódicos com crítica editorial, pois o conhecimento das aplicações criativas (prática profissional) na resolução de problemas e melhoria das condições sociais é a maior responsabilidade de um docente de disciplinas profissionais".

Nos depoimentos dos orientadores observamos pouca menção a preocupações que seriam próprias das atividades de professor - problemas ocorridos em aula, questões da política educacional, etc. Quando questionados sobre que rotina estabelecem com seus alunos, a resposta foi nenhuma para quase todos. Nossa convivência no dia a dia da Faculdade confirma essa observação quando se percebe pouco envolvimento dos docentes com a política de ensino e com atividades que seriam esperadas de um professor, por exemplo, é comum não existir planejamento didático dos cursos com o conjunto de professores envolvidos. O envolvimento do professor com os cursos parece se dar apenas na hora em que está na sala de aula.

Discutindo a política de Pós-graduação no contexto da política educacional, SAVIANI (1994), comenta que "a maior parte dos intelectuais trabalham na universidade e seu trabalho é predominantemente de caráter educativo. Entretanto, se eles consideram a prática dos outros (dos operários, dos bóias-frias, dirigentes políticos etc.) como objeto de estudo rigoroso a ser desenvolvido pela ciência e pela filosofia, via de regra relutam em situar a prática educativa (isto é, sua própria prática) como objeto digno de estudo científico e filosófico. Consideram-na, antes, um problema de senso comum."

Concluindo este primeiro momento de nossa análise identificamos a partir da trajetória profissional e expectativa três grupos diferentes de alunos chegando à pós-graduação. Um primeiro desenho da política institucional valorizou a história profissional de alunos e professores. Tanto com os depoimentos de professores como de alunos percebemos um movimento da Faculdade entre os espaços profissionalizante e acadêmico. 


\section{COMO SE FAZ NO COTIDIANO DA FACULDADE A PÓS-GRADUAÇÃO}

A organização escolar vai definindo um tipo de aluno e de professor, e mostra também a concepção de educação com que se trabalha e que formação se pretende atingir.

Por isso daremos ênfase neste item aos aspectos que pelos depoimentos e documentos evidenciam essa concepção - processo seletivo, disciplinas obrigatórias e eletivas, relação do aluno com o orientador e com a escola.

\subsection{PROCESSO DE SELEÇÃO DOS CANDIDATOS À PÓS-GRADUAÇÃo}

Os alunos trazem para a pós-graduação, conforme apresentado anteriormente, expectativas que em princípio estão de acordo com as finalidades do mestrado e doutorado estabelecidas pela CAPES, e traduzidas pela FSP como "... preparo para o exercício de atividades de pesquisa e de magistério superior, bem como qualificar pessoal de alto nível para os serviços de saúde" (USP, 1994).

Percebemos nos depoimentos dos professores que ao falar sobre a seleção de alunos para o curso, são questionadas as prioridades e as finalidades do mesmo. Lembramos que os entrevistados percebem estar havendo mudança de perfil dos candidatos à pós-graduação. Descreveremos inicialmente o processo seletivo para que essa questão fique mais clara.

O processo seletivo dos candidatos à pós-graduação na FSP é composto por duas fases:

- exames de habilitação - proficiência em inglês e prova escrita para avaliar a capacidade de compreensão, síntese e redação de temas de Saúde Pública - que estão sob a responsabilidade da CPG; e

- seleção nos departamentos em que se situam as áreas de concentração dos candidatos considerados habilitados. Esta 
fase é designada "seleção" e está sob a responsabilidade dos departamentos.

A CPG, portanto, não seleciona o aluno, os departamentos têm autonomia para efetuar a seleção e os professores se sentem responsáveis pela escolha do aluno. Segundo os critérios estabelecidos pelos departamentos, candidatos que são professores universitários têm sido prioridade na seleção. Parece não haver dúvidas sobre dar prioridade ao sanitarista/docente. Porém outros critérios ou métodos de seleção se diferenciam conforme o departamento. Para o ano de $1998^{32}$, os critérios divulgados foram os descritos a seguir.

O HSM apresentou assim suas prioridades: "docentes da FSP; docentes de outras unidades da USP, UNICAMP e UNESP; docentes de outras universidades; pesquisadores; e profissionais técnicos com no mínimo dois anos de prática profissional em saúde".

O HSP, no caso de empate entre os candidatos, quanto às notas na prova de interpretação de texto, dará preferência aos seguintes vínculos: "ser docente e lou pesquisador de universidades e institutos de pesquisa oficiais do Estado de São Paulo; ser docente e/ou pesquisador de instituições particulares de ensino superior; ser docente em serviço público de saúde - ou correlato - de qualquer nível de governo, considerados função e tempo de exercício”.

O HEP, a partir da classificação dos candidatos por nota obtida na prova promovida pela CPG, realiza "processo interno de seleção, feito segundo o interesse mútuo orientador/orientando, com base em currículo, entrevista, atividade e perspectivas de trabalho".

Para o HSA: "cada candidato fará os exames de seleção na área escolhida, através de prova escrita, com questões dissertativas e/ou teste de múltipla escolha. $\mathrm{O}$ candidato será também submetido a entrevista pessoal para avaliar seu interesse, as atividades desenvolvidas, bem como a linha de pesquisa que pretende seguir. A nota final será a média aritmética entre a nota da prova escrita e a nota da entrevista. Em caso de empate será escolhido o candidato que 
tiver obtido maior nota na prova escrita acima referida. Caberá aos orientadores a seleção final dos candidatos aprovados, dentro das suas linhas de pesquisa."

O HNT exige projeto de pesquisa relacionado às suas linhas de pesquisa e carta do candidato explicitando os motivos de sua escolha pela pós-graduação na área de nutrição. Uma comissão designada pelo departamento seleciona os candidatos baseada em entrevista, análise do currículo e do projeto de pesquisa.

A participação do orientador é decisiva e parece pessoal nos departamentos HSP, HEP e HSA; nos outros dois a escolha do aluno se dá de forma mais coletiva. É curioso observar nos processos departamentais descritos que enquanto no exame de habilitação a CPG considera apenas se o aluno está apto ou não, dois departamentos dão caráter classificatório à prova de interpretação de texto.

A Faculdade tem, portanto, formas distintas de efetuar a seleção, mas não deixa claro quais são as razões dessas regras distintas. Parece existir uma ausência de clareza sobre quem selecionar, neste momento.

Os depoimentos dos professores mostram, com exceção aos candidatos docentes, que existem dúvidas sobre a definição do perfil de aluno desejado. Parece estar havendo uma transição nos critérios - que aluno nos interessa mais - aquele que tem mais chance de terminar o curso num prazo aceitável e bom para a avaliação da produção da FSP ou aquele aluno que tem experiência profissional e vínculo empregatício e cujo trabalho de pesquisa e título obtido poderão trazer um retorno para o serviço?

O trecho de depoimento a seguir mostra a preocupação em atingir 0 último objetivo citado.

(3P) Então me preocupa muito ao receber um aluno, na entrevista, saber quem é, de onde vem e principalmente para onde vai. Porque se é um aluno que - ah ... eu sou espetacular, fiz o colegial no Bandeirantes, passei em primeiro lugar. Fiz faculdade na USP, fui o primeiro colocado ... não sei o que ... E entrei agora aqui no primeiro lugar -. - Mas quando você terminou a graduação? -, - terminei no ano passado ... -. E no curriculum dele tem nota 10, etc, ótimo. E agora? O que vai fazer esse aluno? Ele é espetacular, tem nota 10 em tudo ... mas nós vamos investir um ano, dois, três ... em cima dele ... vamos dar a ele um título de mestre 
ou de doutor em saúde pública, e ele vai fazer o que? Então, me preocupa muito o que o aluno vai fazer ... Então, eu até gostaria de ter esses rapazes super inteligentes para desenvolver pesquisas e não sei o que e tal, mas em saúde pública você não precisa ter gente super inteligente, extremamente ... que vai ganhar prêmio Nobel, etc. Até precisa desse pessoal ... mas qual a chance desse indivíduo ... retribuir a sociedade três ... quatro ... cinco anos de custo ... Veja o orçamento da nossa Faculdade, e quantos alunos saem por ano, e veja quanto custa cada aluno (...) Então, nós temos que pensar muito bem nisso como empresa. Essa mentalidade empresarial acho que não pode fugir. É que como nós não temos um dono aqui, cada um de nós é dono, então eu tenho que administrar esses recursos. Bom, no que estiver ao meu alcance. Como? Colocando o melhor possível dos recursos em cima de quem pode utilizar. Se vem um sujeito que é secretário de saúde do município, e veio para cá comissionado para fazer o mestrado e depois vai voltar para lá ... me parece que ele tem muitas mais possibilidades dele retribuir a sociedade que está investindo, pelo menos aparentemente sim. ... então, isso tem que ser visto na hora de você selecionar, o aluno e selecionar o tema do aluno. Então, quando eu vou fazer uma pesquisa de doutorado em que o aluno vai pesquisar qual a influência da espora, da asa ... da perninha esquerda do mosquito e tal ... eu tenho que ver muito bem até que ponto esse detalhezinho é algo que realmente representa uma contribuição para a saúde pública. Se for uma contribuição ao conhecimento puro, fica meio estranho ... porque a Faculdade de Saúde Pública eu entendo como uma faculdade de ciências aplicadas. Por isso que nós temos só graduados aqui, não temos graduação em saúde pública. Porque nós temos que pegar as ciências básicas e aplica-las à saúde pública, eu entendo dessa forma. Então, eu não vou ter uma tese de matemática, de fisiologia, não vou descobrir novos métodos analíticos de toxicologia, nada disso. Esse tipo de pesquisa cabe nas faculdades de graduação.

(3P) Bom ... analisamos o curriculum. Quais os critérios? Um deles é aquele que nós já comentamos: o aluno, mesmo que seja extremamente inteligente, recém formado, ele não é prioritário. $E$ aquele mesmo extremamente inteligente, que está com 35 anos ... 40 anos de formado, também não é prioritário. Por que? Porque o retorno que ele vai dar à Faculdade, desses dois extremos, é pequeno. O recém formado está procurando emprego. Tudo bem, se tiver vaga ele até pode ser aceito. E o que está em final de carreira, está procurando uma aposentadoria melhor ... só. Então, se tiver possibilidade podemos aceitá-los. Então, eles já são prioridade 2.

Prioridade 1: aqueles com algum tempo já de formados e que já vem com uma idéia definida, e que tem alguma ligação com alguma entidade para poder retribuir para a sociedade. Tipo professor, pesquisador de um órgão público, um instituto, de uma companhia tipo CETESB e por aí vai ... Empresas ou pessoas que tem como voltar para a sociedade. Ou seja, terminou o curso, ele volta para seu local de origem e aplica aqueles conhecimentos devolvendo para a 
sociedade aquilo que ele recebeu durante três anos como a gente já falou. Bom, esse é um ponto.

Outro ponto, conversar com ele ... quem é você, de onde vem, para onde vai ...

O próximo depoimento revela o dilema em que o professor se encontra ao selecionar o candidato - entre a acadêmica e o serviço.

(1P) R: é ... Além da entrevista você obtém informações, as pessoas se conhecem, né ... Você pegar uma pessoa, mesmo que ela tenha esse brilho nos olhos ... esse entusiasmo todo, essa garra toda ... até de contribuir muito ... de fazer muita coisa a nível de Brasil ... mas vai fazer uma pós graduação muito longa não é legal ... não é legal para a gente ... para a nossa pós graduação ... Se a gente continuar demorando muito desse jeito, nós vamos cair de nível ... a verdade é essa ... Então, realmente ... estou convencida que a coisa tem que ir mais rápido (...) acho que a própria ... a própria avaliação da ... da própria USP ...me convenceram disto ... esses últimos acontecimentos de CAPES (...) eu acho que talvez isso também seja uma falha, um erro ... Essa história de dizer - não, tem pessoas que estão inseridas em lugares ... -, por exemplo, essa moça do Ministério da Saúde é uma pessoa extremamente competente e produtiva, ela está fazendo mil coisas lá em Brasília, relevantes. Assim ... se você pensar na contribuição que ela está dando ... já é um produto ... e que é muito importante para uma pessoa como ela ter doutorado, está certo? Então, você facilitar o doutorado para ela vale à pena? É ... tá ... só que é um doutorado assim ... no prazo máximo ... tá eu acho que o orientador não pode, e eu acho que essa é uma falha minha de não ter ficado alerta há mais tempo disso, não pode ficar tendo muitos casos assim ... você começa a perceber que muita gente que é desse estilo ... ou que não consegue ... sei lá ... não consegue dar tudo que precisaria dar, uma coisa meio por ali ... (...) você sabe que para o Ministério da Saúde é importante ... alguém de liderança lá ... que não tem mais ninguém assim gabaritado (...) assim como para as federais, você imagina lá em Belém ... que está perdido, que tem uma prevalência altíssima e tal ... ter uma pessoa com doutorado ... Pessoa que tem doutorado, vira uma liderança, ela pode carrear recursos ... ela pode ser ... quantas coisas a pessoa faz com doutorado, né ...

(...) e mesmo naquele caso lá de Belém, daquela moça lá de Belém, eu também tive um vínculo muito grande com ela, durante muito tempo ...

... Eu a conhecia há muito tempo, era uma pessoa muito legal e tal ... então ... estou te contando assim ... parte dos problemas, por que é que eles acontecem ... eu acho que não deve ser uma coisa só minha, possivelmente muitos orientadores devem achar a mesma coisa. Dizer assim - olha, tem um indivíduo lá de serviço, ele é muito enrolado lá no serviço, mas ele é bom ... ele vai demorar mas vai ser ... eu vou deixá-lo fazer, eu vou dar uma mão para ele ... uma força, uma oportunidade para ele -. Agora, por outro lado também é complicado isso ... se vem uma pessoa que está inserida num lugar, aonde é útil ter o título ... como que 
você não aceita a pessoa? Se você for mais radical e falar assim ... não, eu não quero ficar mais com essa estatística desse período prolongado, para os meus orientandos eu não quero ... Agora só aceito quem chegar aqui e tarárá ...É muito complicado você pegar e dizer que você não aceita ... são pessoas que às vezes são conhecidas também ... nos meios, participam das reuniões ... estão militando por aí na área ... como é que você fala - olha ... -. Aí a pessoa vai te falar - mas não tem outro doutorado para fazer ... aonde que eu vou fazer? -, entende? Então ... tem um pouquinho disso também ...

Podemos acrescentar a essas questões trazidas nesses dois depoimentos, a posição do Conselho de Pós-graduação da USP, que segundo um entrevistado não compreende as peculiaridades da FSP.

(6P) $O$ aluno de pós que a COPGr imagina é um aluno que vai da graduação direto para o mestrado? ... isso e que ainda não está inserido no seu mercado de trabalho (...) fica 8 horas no laboratório, fazendo aquilo que você quer, seu pequeno escravinho, e depois de três anos já está terminando e já com um trabalho pronto para publicação (...) nosso aluno as vezes não quer sequer entrar na sua linha de pesquisa, ele quer fazer a pesquisa dele ... a que ele acha que é interessante para ele ...

Sobre essa observação lembramos que os alunos da FSP não são jovens e estão em sua maioria empregados. Percebemos que os alunos que caracterizamos como inseridos em serviços de saúde tem uma preocupação em "resolver problemas" ou refletir sobre sua prática na pós-graduação, portanto trazem questões específicas às quais se apegam e que às vezes não são compatíveis com os temas de trabalho do orientador.

Os professores que possuem linha de pesquisa mais definida reconhecem como um critério importante a ser considerado: receber alunos que já tenham participado do desenvolvimento de pesquisa, mesmo como bolsistas, e que queiram trabalhar com um tema que pertença à linha de pesquisa do professor.

(1P) R: olha, uma coisa que eu faço que é sempre muito interessante é assim: você sempre ... os professores daqui, em geral, eles gostam ... e é louvável que seja assim ... você tem um projeto junto ao CNPq, sempre tem algum projeto junto ao CNPq. CNPq não tem recursos, mas ele concede bolsas. Uma coisa excelente é você ter bolsas de aperfeiçoamento, que é aquele aluno que terminou a graduação e ainda não começou o mestrado, então ... o que é muito interessante é seguir 
esse caminho. Então, esse aluno ele entra num projeto ... o aluno já é formado, né, ele entra num projeto, trabalha dois anos ... com bolsa de aperfeiçoamento e depois resolve fazer mestrado. Aí ele vai, faz mestrado, e depois faz doutorado. Em geral, os alunos fazem isso ... Tem alguns que não passam pelo aperfeiçoamento ... mas são assim ... alguns que a gente conhece ou da graduação, daí se interessam, se aproximam ... Quando a gente está ligado num grupo de pesquisa, realmente é muito fácil isso ... porque assim ... o próprio grupo vai aglutinando pessoas, as pessoas tem vontade de trabalhar naquele tema, que tem aquele grupo de professores que está trabalhando. Então, eles vão ... se aproximam ... mesmo assim ... numa fase que não houve bolsa, eles vão, trabalham ... se inserem, e aí você vai conhecendo as pessoas. E o ideal mesmo é você ter um conhecimento, eu acho que de ambas as partes, assim ... o aluno saber quem vai ser o orientador dele, que qualidades, que defeitos esse professor tem, né, e o professor também saber como que é o aluno, e se ele realmente se interessa, o que ele gosta ... o que é que ... que área que vai se dar melhor ... né. E depois uma outra coisa que eu acho bem importante também, assim ... em que medida depois ele volta para o local dele e ele continua a tocar coisas.

Outros professores desse grupo deixam clara a necessidade de haver identidade do tema de pesquisa entre professor e aluno.

(7P) R: não, o que eu defino é o seguinte, tem que fazer a linha de trabalho que eu faço, quer dizer, não vou pegar um cara que seja de linha diferente. Esse é o primeiro critério.

O segundo, que eu conheça um pouco o cara ... que eu tenha alguma coisa para conhecer ... nunca peguei nenhum aluno exclusivamente pelo curriculum ... para ver o curriculum e dizer - bem ... esse aqui é um bom -, nunca aconteceu. Sempre vejo o curriculum e vejo a pessoa, o que está fazendo (...) converso ... quer dizer, vai muito também da empatia (...) atualmente eles pegam (Departamento) pelas notas e eles mandam para a gente o curriculum, a pasta do aluno, o curriculum, com a prova dele e a gente chamaria para uma entrevista. Não sei se todos chamam para uma entrevista, eu chamo para uma entrevista, né ... aí eu escolho entre os que tem um curriculum mais adequado, etc ...

(5P) Olha, essa questão da escolha é uma questão ... eh ... a questão da escolha eu digo assim: o aluno que a gente tem aqui, na verdade, é um aluno que em grande parte já passou pela especialização, então você na especialização ... seja em aula, seja conversando, etc, acaba conhecendo um pouco dele. Conhecendo um pouco do aluno. Acho que tem a escolha do tema, é um outro dado importante, Quer dizer, além do conhecimento embora superficial do aluno, a escolha do tema ela traduz uma certa identidade.

Dos alunos entrevistados apenas dois relataram estar desenvolvendo trabalho na linha de pesquisa do orientador - a aluna recém-formada que veio com a 
expectativa de se preparar para iniciar carreira docente; e a aluna de doutorado que procurou a FSP justamente para ser orientada por professor que desenvolvia a linha de pesquisa desejada por ela.

Apenas um dos professores entrevistados manifestou mais claramente ver o aluno como uma pessoa que está se encaminhando profissionalmente, no contexto acadêmico e espera que ele replique sua linha de pesquisa.

(5P) ... deveriam ter programas que estimulassem mais a participação do aluno de pós graduação nos programas do Departamento da escola, da linha de pesquisa. Defendo totalmente, porque na experiência pequena mas que até agora ... o que eu tenho visto é que justamente na participação desse programa de pesquisa, é que ele também vai se definindo profissionalmente. Quando é o caso também dele não estar passando pela pós graduação como também um tampa buraco profissional. Mas o que eu tenho visto na experiência é que abre portas, quer dizer, no mínimo abre portas dar uma aula e ele ... se perceber como tal para bater na porta de uma faculdade e pegar aulas ali ... quer dizer, sair dando aula ou outras coisas que apareçam.

(5P) ...Eu não faria aquela divisão, o mestrado mascara o mercado de trabalho. Não, acho que enquanto está no mestrado e quando surgem outras oportunidades de participação em pesquisa, de participação em outras coisas, eu acho que é experiência.

$P$ : e você tem uma experiência com teus orientandos que mostra isso.

R: que mostra isso como um aspecto positivo, quer dizer, construindo experiência. Eu sinto assim, eu sinto que no decorrer do curso, então uma delas arranja aulas numa faculdade, então começa ... acaba o mestrado e enfim ... vai dar aula numa outra instituição de terceiro grau. Ou então outra arranja uma pesquisa, um outro curso ou uma bolsa no exterior. Então, de alguma forma eu sinto assim: uma perspectiva de encaminhamento. Quer dizer, para mim é importante: eu sinto o seguinte, que a gente também se envolve com os orientandos e aí se envolve um pouco também com essa situação do orientando, de encaminha-lo. Eu acho que não basta, eu acho que não vejo aquela função, né, quer dizer, bom, eu tenho o orientando para fazer uma dissertação ou fazer uma tese, etc. Não, eu acho que uma vez que você convive um tempo aqui e tem uma convivência mais intensa, você quer ver o orientando replicando aquela linha de pesquisa, quer dizer, produzindo também. No sentido dele produzir alguma coisa, de estar crescendo. O que eu chamo de crescimento? Uma habilidade em relação à pesquisa, em relação ao ensino, né, quer dizer, ao estar dando aula, estar procurando aula, né, ao tema escolhido, quer dizer, a contribuição em relação ao tema. Isso eu acho um dado importante. Eu sinto o seguinte, principalmente o orientando que tem bolsa, é muito importante a participação dele, acho que ele acaba participando no dia a dia do trabalho daqui ... que se faz aqui na escola, do trabalho de pesquisa de 
docência e de prestação de serviços à comunidade. Acaba se envolvendo nesse tripé.

Em resumo, ao analisarmos o processo seletivo dos candidatos à pós-graduação, encontramos diferentes critérios conforme o departamento da FSP e identificamos os professores conflitados entre a academia e o serviço ou seja a que interlocutor responder, aquele que tradicionalmente foi parceiro da FSP ou à academia? Os diversos posicionamentos dos docentes são representativos da fase de transição em que principalmente o mestrado da FSP se encontra.

\subsection{DISCIPLINAS OBRIGATÓRIAS}

Cursos de pós-graduação interdisciplinares, ou transdisciplinares, estão sendo estimulados e valorizados pelo pensamento acadêmico atual. A área de saúde pública desde o seu início foi assim se conformando.

O campo da saúde pública envolve as dimensões biológicas, econômicas, políticas e sociais. Nesse campo ocorre a nossa pós-graduação. É um campo complexo e para responder a ele, o curso deve lidar com várias disciplinas, buscando elementos para compreensão do seu objeto. Nesse sentido uma característica do corpo docente e discente da FSP é a de possuir profissionais de diferentes formações na graduação.

A multiprofissionalidade, no discurso de professores e alunos, é uma grande qualidade da área. Porém ao viver nessa diversidade profissional surgem algumas questões. Caberia perguntar como profissionais que têm experiências e conhecimentos de áreas de saber distintas convivem na pós-graduação. Como a FSP trabalha em relação ao corpo de conhecimento básico em saúde pública para os diferentes profissionais que compõem o corpo discente?

Buscamos uma primeira resposta identificando a procedência dos seus participantes nas Comissões Julgadoras de exames de qualificação e defesas de mestrado e doutorado da FSP. Os resultados desse levantamento (Tabela 9) mostraram uma predominância de professores das ciências da saúde, com maior porcentagem da saúde coletiva (incluindo a própria FSP). Chamamos à atenção para a importante participação da medicina. Somada a essa observação lembramos a composição do corpo docente e discente apresentada no Capítulo 2 (Tabelas 2 e 
6), onde se encontra predominância também de profissionais da saúde.

Poderíamos a partir dessas constatações e considerando a tradição do campo e as origens da saúde pública, dizer que deve haver uma predominância da dimensão biológica na nossa pós-graduação.

Mas para responder às perguntas citadas priorizamos a busca a essas respostas no estudo das disciplinas obrigatórias da pós-graduação por considerarmos que elas são emblemáticas do que a FSP considera o conhecimento básico em saúde pública. Os depoimentos tanto de alunos como de professores foram ricos em observações sobre este assunto.

Para situar o leitor iniciaremos descrevendo a composição dessas disciplinas no curso.

A introdução das disciplinas obrigatórias, compondo o corpo de conhecimento básico na pós-graduação, tem sua origem na estrutura do curso de especialização em saúde pública.

(6P) ...eu acho que as pessoas precisam conhecer o que é saúde pública e precisam ter um conhecimento padrão aí ... é porque o que existia antigamente era um pré requisito, então não era uma questão da pós ... já vinha ... selecionava antes isso, né ...

As disciplinas obrigatórias entraram no currículo em 1991, junto com outras alterações (Anexo 5). A reformulação ocorrida nesse ano retirou os prérequisitos referentes a conhecimento em saúde pública, exigidos desde a criação do curso, primeiro com o curso de especialização em saúde pública e depois com provas de conhecimento; e introduziu as obrigatórias. No primeiro ano foram ministradas em conjunto com a Especialização em Saúde Pública, conformando um modelo de curso em "y", ou seja uma fase inicial conjunta e depois uma bifurcação, especialização e mestrado - o que ocorreu apenas por dois anos, depois os cursos foram totalmente desmembrados, e as obrigatórias foram mantidas para a pósgraduação. 
Tabela 9 - Pós-Graduação stricto sensu FSP/USP

Membros das Comissões Julgadores de exames de qualificação e defesas segundo área de concentração. 1990 a 1996 *.

\begin{tabular}{|c|c|c|c|c|c|c|c|c|c|c|c|c|c|c|}
\hline \multirow[b]{2}{*}{ Total } & \multicolumn{2}{|c|}{ SSP } & \multicolumn{2}{|c|}{$\mathrm{AH}$} & \multicolumn{2}{|c|}{ SA } & \multicolumn{2}{|c|}{ NUT } & \multicolumn{2}{|c|}{ SMI } & \multicolumn{2}{|c|}{ EPI } & \multicolumn{2}{|c|}{ Total } \\
\hline & $\begin{array}{r}\mathrm{n}^{\circ} \\
900 \\
\end{array}$ & $\begin{array}{c}\% \\
100,00 \\
\end{array}$ & $\begin{array}{l}\mathrm{n}^{\circ} \\
82 \\
\end{array}$ & $\begin{array}{c}\% \\
\mathbf{1 0 0 , 0 0}\end{array}$ & $\begin{array}{r}\mathrm{n}^{\mathrm{o}} \\
407 \\
\end{array}$ & $\begin{array}{c}\% \\
\mathbf{1 0 0 , 0 0}\end{array}$ & $\begin{array}{r}\mathrm{n}^{\circ} \\
298 \\
\end{array}$ & $\begin{array}{c}\% \\
100,00\end{array}$ & $\begin{array}{r}\mathrm{n}^{\circ} \\
\mathbf{3 4 2} \\
\end{array}$ & $\begin{array}{c}\% \\
\mathbf{1 0 0 , 0 0}\end{array}$ & $\begin{array}{r}n^{\circ} \\
852 \\
\end{array}$ & $\begin{array}{c}\% \\
100,00\end{array}$ & $\begin{array}{r}n^{\circ} \\
2.881 \\
\end{array}$ & $\begin{array}{c}\% \\
100,00 \\
\end{array}$ \\
\hline C. Saúde (total) & 713 & 79,22 & 68 & 82,92 & 277 & 68,05 & 257 & 86,24 & 288 & 84,21 & 720 & 84,50 & 2.323 & 80,63 \\
\hline Saúde Coletiva & 508 & 56,44 & 43 & 52,44 & 220 & 54,05 & 184 & 61,74 & 225 & 65,79 & 457 & 53,64 & 1.637 & 56,82 \\
\hline Med Preventiva & 59 & 6,56 & 13 & 15,85 & 22 & 5,41 & 16 & 5,37 & 17 & 4,97 & 121 & 14,20 & 248 & 8,61 \\
\hline Medicina & 51 & 5,67 & 5 & 6,10 & 10 & 2,46 & 35 & 11,74 & 24 & 7,02 & 99 & 11,62 & 224 & 7,78 \\
\hline outras C. Saúde & 95 & 10,55 & 7 & 8,53 & 25 & 6,14 & 22 & 8,05 & 22 & 6,43 & 43 & 5,04 & 214 & 7,42 \\
\hline C. Biológicas & 34 & 3,78 & - & - & 20 & 4,91 & 10 & 3,36 & 1 & 0,29 & 34 & 3,99 & 99 & 3,44 \\
\hline C. Humanas & 54 & 6,00 & 1 & 1,22 & 11 & 2,70 & 2 & 0,67 & 36 & 10,53 & 13 & 1,53 & 117 & 4,06 \\
\hline C. Soc Aplicadas & 11 & 1,22 & 5 & 6,10 & - & - & 2 & 0,67 & - & - & 4 & 0,47 & 22 & 0,76 \\
\hline C. Exatas e da Terra & 1 & 0,11 & - & - & 6 & 1,47 & - & - & 7 & 2,05 & 12 & 1,41 & 26 & 0,90 \\
\hline C. Agrárias & 33 & 3,66 & - & - & 2 & 0,49 & - & - & - & - & - & & 43 & 0,03 \\
\hline Engenharias & - & - & - & - & 60 & 14,74 & 3 & 1,01 & - & - & - & & 63 & 2,19 \\
\hline Ling. Letras e Artes & 1 & 0,11 & - & - & 1 & 0,25 & - & - & - & - & 3 & 0,35 & 5 & 0,17 \\
\hline Especialista não docente & 34 & 3,78 & 8 & 9,76 & 20 & 4,91 & 15 & 5,03 & 8 & 2,34 & 37 & 4,34 & 122 & 4,23 \\
\hline s/inf & 19 & 2,11 & - & - & - & - & 7 & 2,34 & 2 & 0,58 & 24 & 2,82 & 62 & 2,15 \\
\hline
\end{tabular}

*Não inclui os exames de qualificação de 1990 a 1993

Não inclui os orientadores 
Atualmente para o mestrado são disciplinas obrigatórias, eqüivalendo a 21 créditos $^{33}$ (315 horas) - bioestatística; epidemiologia; administração de serviços de saúde e políticas de saúde; saúde e sociedade; e metodologia de pesquisa em saúde (Quadro 3).

\section{Quadro 3 - Pós Graduação stricto sensu FSP/USP Disciplinas Obrigatórias para o MESTRADO segundo número de créditos e ano, 1990 a 1997.}

\begin{tabular}{|c|c|c|c|c|c|c|c|c|}
\hline Nome da Disciplina & 1990 & 1991 & 1992 & 1993 & 1994 & 1995 & 1996 & 1997 \\
\hline Epidemiologia I & & 10 & 5 & 5 & 5 & 5 & 5 & 4 \\
\hline Bioestatística I & & 8 & 7 & 7 & 7 & 7 & 7 & 5 \\
\hline $\begin{array}{l}\text { Meio Ambiente e Saúde } \\
\text { Pública }\end{array}$ & & 6 & 3 & 3 & 3 & & & \\
\hline Saúde e Sociedade & & 7 & 5 & 5 & 5 & 5 & 5 & 3 \\
\hline $\begin{array}{l}\text { Administração de Serviços } \\
\text { de Saúde e Políticas de } \\
\text { Saúde }\end{array}$ & & 10 & 6 & 6 & 6 & 6 & 6 & 3 \\
\hline $\begin{array}{l}\text { Didática do Ensino Superior } \\
\text { aplicada a Saúde Pública }\end{array}$ & & 6 & 5 & 5 & 5 & 5 & 5 & \\
\hline $\begin{array}{l}\text { Alimentação e Nutrição em } \\
\text { Saúde Pública }\end{array}$ & & & & 3 & 3 & & & \\
\hline $\begin{array}{l}\text { Fundamentos da } \\
\text { Investigação Científica* }\end{array}$ & & 7 & 6 & 6 & 6 & 10 & 10 & 6 \\
\hline $\begin{array}{l}\text { Metodologia de Pesquisa em } \\
\text { Saúde: teoria* }\end{array}$ & & & & 10 & 10 & 10 & 10 & 6 \\
\hline $\begin{array}{l}\text { Interpretações e abordagens } \\
\text { qualitativas na Saúde } \\
\text { Pública: Contribuição para a } \\
\text { pesquisa, diagnóstico e } \\
\text { planejamento* }\end{array}$ & & & & & & & & 6 \\
\hline $\begin{array}{l}\text { Introdução a investigação } \\
\text { científica em alimentos, } \\
\text { nutrição e saúde pública* }\end{array}$ & & & & & & & & \\
\hline $\begin{array}{l}\text { Total de créditos em } \\
\text { disciplinas obrigatórias }\end{array}$ & $\begin{array}{l}0 \\
-\end{array}$ & $\begin{array}{c}54 \\
648 \mathrm{~h}\end{array}$ & $\begin{array}{c}37 \\
444 \mathrm{~h}\end{array}$ & $\begin{array}{l}40480 \mathrm{~h} \\
44492 \mathrm{~h}\end{array}$ & $\begin{array}{l}40480 \mathrm{~h} \\
44492 \mathrm{~h}\end{array}$ & $\begin{array}{c}38 \\
456 h\end{array}$ & $\begin{array}{c}38 \\
456 \mathrm{~h}\end{array}$ & $\begin{array}{c}21 \\
315 \mathrm{~h}\end{array}$ \\
\hline $\begin{array}{l}\text { Total de créditos exigidos em } \\
\text { disciplinas para o mestrado }\end{array}$ & $\begin{array}{l}60^{* *} \\
720 \mathrm{~h}\end{array}$ & $\begin{array}{c}90 \\
1080 \mathrm{~h}\end{array}$ & $\begin{array}{c}90 \\
1080 h \\
\end{array}$ & $\begin{array}{c}80 \\
960 \mathrm{~h}\end{array}$ & $\begin{array}{c}80 \\
960 \mathrm{~h}\end{array}$ & $\begin{array}{c}80 \\
960 \mathrm{~h}\end{array}$ & $\begin{array}{c}80 \\
960 \mathrm{~h}\end{array}$ & $\begin{array}{c}48 \\
720 h\end{array}$ \\
\hline
\end{tabular}

não fazia parte da Grade Curricular.

* O aluno deve optar por uma dessas disciplinas.

** Eram exigidos 60 créditos em disciplina e 30 em estágio.

Fonte: Seção de Pós Graduação FSP/USP

33 Um crédito disciplinar , em 1997, passou de 12 para 15 horas. 
No período de 1991 a 1997, o elenco das disciplinas obrigatórias na FSP sofreu alterações quanto ao tema da disciplina e quanto ao número de créditos. A tendência foi manter as disciplinas que compunham o quadro de disciplinas comuns às diferentes áreas temáticas/profissionais da Especialização em Saúde Pública.

Matérias como Alimentação e Nutrição em Saúde Pública, e Meio Ambiente e Saúde Pública foram incluídas inicialmente de tal forma que a maioria dos departamentos da FSP tiveram uma disciplina obrigatória sendo ofertada. Nos últimos sete anos várias revisões foram feitas e os totais de créditos disciplinares exigidos para o mestrado sofreram alterações - indo de 90 créditos (1080 horas), em 1991 a 48 (720 horas) em 1998, ou seja as obrigatórias correspondem atualmente a $44 \%$ dos créditos disciplinares.

A preocupação em diminuir o número de créditos exigidos esteve associada à necessidade de reduzir o tempo de titulação do aluno.

Quase todos os cursos de mestrado da área de saúde coletiva no Brasil possuem disciplinas obrigatórias. Epidemiologia, metodologia de pesquisa; ciências sociais aplicadas à saúde pública ou saúde e sociedade; e políticas de saúde, são matérias comuns aos cursos. Bioestatística é obrigatória para a metade deles; e saúde e trabalho apenas para o da UFMG. Os dois cursos destinados exclusivamente a médicos, são da USP, e não possuem disciplinas obrigatórias, porém têm como pré-requisito estabelecido pelos programas de pós-graduação em medicina da USP, e não pela área de concentração, a residência em medicina preventiva.

Uma questão identificada como polêmica para a área é a definição desse corpo de conhecimento obrigatório ou básico e a necessidade ou não dele ser desenvolvido na forma de disciplinas. As oficinas de trabalho, promovidas pela ABRASCO em 1996 e 1997, buscaram a opinião de representantes de cada curso de pós-graduação em saúde coletiva do País quanto a um núcleo básico comum procurando indicar "rotas orientadoras, sem pretender uma padronização dos cursos de pós-graduação, ou mesmo encontrar um consenso".

Essas opiniões em síntese se dividem em pareceres favoráveis às disciplinas e em outros que apontam as desvantagens dessa proposta, indicando 
outras estratégias para trabalhar a questão do conhecimento básico em saúde pública nos cursos. Os pareceres favoráveis baseiam-se nas seguintes argumentações: é necessária a "formação de um profissional com cultura geral em saúde coletiva"; permite a "constituição mais homogênea de um perfil acadêmico, a socialização de um mesmo estado da arte do conhecimento, um intercâmbio em termos de avanço de conhecimento na área”; enfim um núcleo básico comum se apresenta como um elemento importante na "construção da identidade da área".

Segundo NUNES e COSTA (1997) "O que se acrescenta é o fato de que se deveria pensar que, frente a uma série de elementos novos, ocorridos ao longo dos quase trinta anos que demarcaram o surgimento dos primeiros cursos de pósgraduação - como a intensa multiprofissionalidade do campo, a extensão dos objetos e campos sobre os quais a Saúde Coletiva trabalha, a diminuição do tempo para titulação, a maior vigilância sobre a produção e a produtividade da área, a demanda de profissionais procedentes dos serviços de saúde - a questão de como se configura a grade curricular não fica adstrita ao básico, mas se estende ao comum".

Para esse autor, alguns vocábulos, presentes em quase todos os discursos de representantes dos cursos, caracterizam como tem sido o caminho da Saúde Coletiva. "Assim, ser uma área diversificada é opinião geral; que deva haver alguma coisa que nos une; que a busca no campo científico é a de trabalhar com elementos comuns, estrutura de códigos que permita o diálogo; a invasão de outros campos, mas também a não presença de algumas áreas; e a necessidade de um corpo doutrinário que identifique a área. Mas, pairando acima desses aspectos, as perguntas: quem somos? Qual a nossa cara? Qual a nossa identidade? Foram constantes nos diálogos estabelecidos na Oficina”.

São questões tidas como polêmicas e complexas. A definição sobre um corpo de conhecimento que dê um repertório comum ao sanitarista traz alguns riscos, consideramos o principal deles, o de negar a diversidade, e o respeito à diversidade que o objeto - Saúde Pública - exige. A constituição mais homogênea pode, a nosso ver, passar a constituir uma camisa de força para o tão desejado diálogo entre os campos de conhecimento envolvidos na saúde pública. 
São questões que a FSP sempre procurou enfrentar com o Curso de Especialização em Saúde Pública e que estiveram presentes durante as discussões sobre a reformulação do mesmo. Duas preocupações foram trazidas pelo grupo encarregado de estudar a reformulação ${ }^{34}$ : a necessidade de "aprender a linguagem da saúde pública" e de o aluno ter "um banho de saúde pública" versus a de "trabalhar na diversidade dentro de uma lógica institucional", "exercitar a criatividade para resolver, por exemplo, esse problema da 'caixa comum' em que os alunos são colocados no curso".

A convergência de profissionais de diferentes áreas para a saúde pública era absorvida na especialização. O programa dos cursos de pós-graduação da FSP tem forte influência desse Curso. Podemos dizer que existe um "apego" à especialização como referência de identidade da área.

Percebemos existir uma grande interface entre a especialização em saúde pública e o mestrado, por isso nos deteremos em fazer algumas considerações sobre esse curso, cuja problemática invade o nosso mestrado.

A especialização pela história de ensino na FSP sempre foi vista como o curso que mostrava "a nossa cara", a "nossa identidade". Correspondia ao que a escola entendia por formar o sanitarista. Essa referência de identidade a nosso ver foi transferida para o mestrado.

No catálogo que apresenta o Curso de Especialização em Saúde Pública (USP 1993), encontramos a seguinte referência à formação do sanitarista:

\begin{abstract}
"Durante todos esses anos, havia sempre a preocupação de garantir ao alunado a aquisição da "visão de sanitarista", ou seja, dar acesso a todo um corpo de conhecimento que garantisse ao profissional uma maneira própria, caraterística, que buscasse a saúde da população, que tivesse essa visão de conjunto do homem no seu meio, agente e paciente de alterações ambientais de conseqüências variadas, que procurasse
\end{abstract}

34 Universidade de São Paulo. Faculdade de Saúde Pública. Grupo tarefa encarregado da reformulação do Curso de Especialização em Saúde Pública para o ano de 1996. São Paulo; 1994 [Relatório] 
explicar as relações entre saúde e doença, no contexto social; em suma, que possibilitasse a profissionais uma filosofia de trabalho e uma maneira peculiar de enxergar o espaço de atuação, dando-Ihes o instrumental necessário de análise e informação.

Dada a inexistência de Graduação em Saúde Pública, os cursos têm, necessariamente, um papel formativo, assumindo, de certa forma, um caráter de Curso de "especialização generalista", que tem sido mantido nas reformulações feitas ao longo do tempo".

A transformação do sistema de saúde brasileiro influenciou decisivamente nos tipos de especialistas em saúde pública requeridos para os serviços de saúde. Com isto intensificou-se o questionamento sobre a pertinência da formação generalista - "passou o tempo da figura clássica do sanitarista"35. Ao mesmo tempo, a extinção da carreira de sanitarista, na SESSP, também interferiu na demanda para o Curso. Na FSP, além da mudança do perfil profissional dos alunos observou-se a diminuição do número de candidatos ao Curso, e a oferta de outros cursos de especialização.

Nesse contexto, acrescentando-se críticas dos alunos ao desenvolvimento do Curso, a FSP montou, em 1996, um Grupo de Trabalho para estudar reformulações no Curso. O grupo, formado por 18 docentes e três alunos, após identificar os pontos críticos, fez cinco recomendações das quais destacamos as seguintes:

- "que o Curso, com a atual configuração, seja suspenso por tempo indeterminado, a partir de 1996.

- que a criação de novos cursos de especialização no campo da Saúde Pública seja estimulada, tendo como diretrizes:

- atender ou criar demandas sociais de formação/capacitação em Saúde Pública;

35 Universidade de São Paulo. Faculdade de Saúde Pública. Grupo tarefa encarregado da reformulação do Curso de Especialização em Saúde Pública para o ano de 1996. São Paulo; 1994 [Relatório] 
- possuir a terminalidade característica de cursos de especialização;

- considerar modalidades e tecnologias de ensino inovadoras;

- trabalhar temas emergentes da Saúde Pública; trabalhar com conteúdos programáticos que indiquem a possibilidade de desenvolvimento de linhas de investigação; definir distintivamente os espaços e objetivos dos cursos de pósgraduação "lato sensu" e "stricto sensu", de forma a não haver sobreposição."

Foi uma discussão bastante polêmica para o conjunto de docentes e apesar da extinção proposta ter se efetivado36, não podemos afirmar que haja consenso na FSP sobre essa questão.

(7P) é ... eu acho que a gente ainda está lutando pelo sanitarista no sentido que a gente sabe, né ... no que a gente entende. Eu não sei se a gente vai conseguir isso por mais tempo, porque o que a gente está vendo é desmoronar tudo ... Eu acho que ainda, com os alunos atuais, ainda esse sentido está presente, essa concepção está presente. Mas eu tenho muito medo que isso a gente vai perder. Porque com essa especialização, com essa tendência a essa especialização cada vez mais e essa ... que volta a ser essa história da uni visão. Eu acho que a gente vai perder isso.

(8 P) ... com o término do cursão de especialização ... eu particularmente não tenho clareza sobre isso, não participei desse processo de discussão ... A minha visão ... pode ser uma visão ultrapassada, né ... essa visão de generalistas, né ... Que isso foi uma coisa muito presente na visão da clínica médica, da medicina preventiva ... caminhos híbridos que pudessem permitir esse caminho do individual e coletivo ... Eu estou muito ... essa é uma questão que já estava colocada naquela época ... a questão da especialização ... de você ir cada vez mais segmentando, fragmentando ... sempre acho que você tem que ter uma visão integradora ... de você buscar as ligações, as interfaces ... uma coisa global. ...

As mudanças comentadas, que justificaram o encaminhamento dado à especialização, não se restringem a esse nível de curso. Está havendo também

36 Em 1998, o Curso de Especialização em Saúde Pública não foi oferecido. 
mudanças no mestrado, a problemática da demanda ao curso de especialização vêm aos poucos "invadindo o mestrado". O aumento do número de vagas, o perfil profissional dos alunos, as alterações nos pré-requisitos para o mestrado, as alterações nos serviços de saúde podem também ter sido fatores que favoreceram a abertura da pós-graduação para profissionais com trajetórias diferentes da apontada até este momento.

Alunos e professores trouxeram diferentes pontos de vista sobre as disciplinas obrigatórias. Todos comentam a questão partindo do fato que o grupo de alunos é heterogêneo, não só em termos de formação na graduação mas principalmente quanto à experiência profissional e conhecimento em saúde pública acumulado previamente ao curso de mestrado.

A partir dessa consideração a questão colocada é a da adequação da resposta encontrada pela FSP para dar aos alunos um repertório comum em saúde pública. Adequação essa expressa em termos de conteúdo e forma.

Para os alunos iniciantes na área, as obrigatórias parecem ter trazido um aprendizado grande e importante.

Numa primeira aproximação com o tema, eles repetem o discurso da FSP sobre as obrigatórias.

(8A) Então, acho que ... muitas das disciplinas que a gente faz aqui, é para cumprir crédito mesmo, não adianta. Agora, para mim eu achei que foi bom, porque ... para me situar melhor no programa da pós graduação, afinal de contas eu vou sair com o título de mestre em saúde pública, não é de nutrição. E eu não tenho essa experiência em serviços ... o conteúdo que eu tinha era um conteúdo de graduação, né, conteúdo teórico. Então, assim, foi importante ter essas disciplinas obrigatórias ... eu acho que elas são importantes por dar esse nivelamento do conteúdo de saúde pública. Como a seleção não é feita em base de um conhecimento em saúde pública, então você precisa dar isso, no final de contas você pega um título de mestre em saúde pública.

Porém, no desenrolar do depoimento, esses alunos trazem duas críticas a primeira acerca do próprio "nivelamento de conhecimento".

(10A) O que eu não gosto das disciplinas, que não gosto não, que eu não acho que é certo, por exemplo ... você é formada em estatística, e entrou no mestrado, e você faz bioestatística, gente, isso é o básico do básico ... 
como um formado em estatística tem que fazer aquilo? (...) como tinha nutrição, na minha época tinha nutrição, que eu adorei, porque eu não sou nutricionista foi ótimo ter nutrição, aprendi um monte de coisas, mas para quem é nutricionista aquilo ... é o básico ... Ai eu ficava olhando as meninas, falava - como é que pode obrigar essas meninas a assistir essa aula? -, poderia estar fazendo uma outra coisa, né. Eu acho que ... então isso eu acho que tinha que ver um pouquinho de que área você vem e o que você vai fazer ...

$P:$ e você que vem das ciências sociais ...

R: é ... Saúde e Sociedade ... é fazer Saúde e Sociedade, eu ficava lá ...ah ... enchia ... aí dava coisa para ler, dar seminário, eu falava - ah, voltei para a graduação de novo -, aí não era muito a minha fazer isso. Então, das disciplina eu acho isso.

(10A) (...) fiz ciências sociais não quero discutir teoria de Marx na Saúde Pública. Quero justamente o que eu não tenho.

(8A) (...) quem é da área qualitativa, será que precisa fazer tanta estatística como disciplina obrigatória? Quem é da área da nutrição, será que precisa ver tanta política ... administração de saúde como a gente vê? Quem é da quantitativa pura, será que precisa ver tanta saúde e sociedade?

Um outro aspecto dessa questão é levantada por aluno formado há vários anos e que vê a disciplina básica como uma possibilidade de atualização de conhecimento.

(9A) para o engenheiro, bioestatística... seria dispensável ... Agora no meu caso eu fiz engenharia há 20 anos ... então muita coisa eu não lembrava mais (...) e a professora ... ela é muito boa.

A segunda crítica diz respeito à operacionalização das disciplinas.

(8A) Agora, eu me assustei nas obrigatórias, porque eu cheguei e vi um "escolão" ... eu não imaginei que a pós graduação fosse isso. Sala de aula com 50 alunos ... nem no curso, na graduação tinha 30 alunos (...) você não espera isso de um programa de pós graduação.

(8A) Só que a forma como isso é dado e que tem que ser questionada. Acho que o problema que tem a Faculdade é assim: se mantém o programa das disciplinas obrigatórias, que eu acho que tem seu valor e que tem sua razão de manter, mas não cuidam das disciplinas obrigatórias. Elas são tratadas como qualquer uma disciplina e são as principais disciplinas por serem obrigatórias. Todo mundo tem que fazer e não cuida, então vira o que é ... o que a gente verifica, né. Esse escolão, onde o programa não se reformula ... onde os pós graduandos não são ouvidos ... então assim: tem gente que tem uma experiência enorme a 
gente via em sala de aula, e que nem eram considerados pelo docente ... nem tinha condições de considerar a experiência dele porque era aquilo ali de sala de aula, de ver conteúdo, cumprir carga horária ... sem troca nenhuma, né.

(...) Se fosse uma outra estrutura das disciplinas obrigatórias, acho que tinha que se repensar o processo de seleção. Da forma como é, entra qualquer um. Entra aquele que tem uma super experiência e aquele que não tem experiência nenhuma. Então, aí que se propõem essas disciplinas obrigatórias para dar esse nivelamento.

Agora ... se você faz grupos menores ... acho que seria mais rico ... Agora, por outro lado, teria uma troca maior com as pessoas que tem experiência. Porque eu sei o que, sei que tem o SUS, né, mas e daí?, e daí ... o que isso muda para mim ... ter todo o abecedário do SUS, da forma como foi dado? Isso não muda nada, né. $O$ que isso representa no meu projeto? Não representa nada.

(10 A) ... Aquele negócio de dividir o pessoal quando entra para fazer ... como é que fala? As obrigatórias, que divide o pessoal da epidemio ... quem é formado na área médica, vamos dizer, quem é dessa área e quem é de humanas, eu achei fundamental. Eu acho que tem que ser aquilo mesmo, não dá para misturar. Você já imaginou, você senta com um médico, ele tem outro nível ... né. E eu acho que é legal dividir, isso eu também gostei. Acho que está mais do que certo dividir ... por exemplo, e dar ... (...) eu acho que Saúde e Sociedade, a gente que fez ciências sociais, ajudava muito o pessoal da área médica, que eles tinham uma dificuldade para ler o texto, imensa. Eu lembro de um médico que sentava do meu lado e falava assim - eu não entendo nada do que está escrito aqui ... -, e eu sentei com ele para ler o texto, falei - olha, eu vou ler o texto com você ... vou te marcando então, vou te mostrando ... -, quando eu li junto com ele ... ele falou - nossa!, mas eu entendi muito melhor ... -. Eu acho que quando é a coisa de humanas assim ... a gente até tem mais para dar ... vamos dizer ... mas talvez fosse interessante, porque você pode dar o curso diferente para uma e outra área. Eu acho que é muito difícil para quem é de outra área entender ... assim ... as ciências sociais. Os textos são pesados ... eu acho ... até mais pesados que medicina. Então, eu acho que para eles era importante.

Tanto alunos como professores indicam o grande número de alunos na sala de aula (no mínimo 70) como um grande problema. Para os alunos uma solução seria avaliar caso a caso a necessidade de freqüentar todas as disciplinas, ou ainda dividir o grupo de alunos. Esta situação parece reforçar a idéia de que realmente se busca passar um conhecimento padrão para todo o grupo junto.

Ao lado do reconhecimento da heterogeneidade do grupo, no momento da aula essa heterogeneidade não é considerada o que causa sofrimento para quem 
já traz conhecimento em saúde pública e para quem ainda não tem.

(5A) ... na época que eu fazia o curso, o pessoal que não era da saúde pública, que não era sanitarista já ... o pessoal achou uma dificuldade danada de acompanhar aquele curso ... saber o que estava acontecendo ... Tentar entender ... onde é que uma coisa cruzava com a outra ... o que tinha a ver ... por que estava se falando aquilo ali ... né.... e acaba pedindo ajuda para os colegas (...) inclusive aqui eu já vi uma pessoa que era clínica e que fez o curso e veio falando desesperada - ah, o que é aquele curso, eu não consigo entender ... juntar nada com nada ... não sei qual é a finalidade daquilo -

(10A) mas vamos supor que eu sou de fora, eu vou fazer doutorado lá e aí eu vou ter que fazer todos os do mestrado? Como que não considera o que a pessoa tem? Tenho uma amiga que está com esse problema, porque ela fez mestrado na UNICAMP, antropologia. A tese dela é sobre o PAISM - o programa de assistência à mulher .... é sobre a história do PAISM ... ela trabalha no CEMICAMP há ... muito mais de 10 anos ... Ela dá aula como professora convidada num curso de mestrado para médicos, que é da tocoginecologia ... ela dá aula no curso de metodologia. Um monte de coisas ela sabe ... e ela tem que fazer essas coisas do mestrado ... ela tem que fazer mais créditos porque ela não é formada lá ... E assim, e ela tem uma bagagem que a gente brinca até ah, quando eu crescer eu quero ser igualzinha a ela ... -, porque ela é ótima!, e aí você olha assim - não acredito -, uma pessoa, morar aqui (Campinas), fazer todos esses créditos ... é muito mais difícil, né.

(10 A) Acho que teria o professor que sentar com você e falar - olha, vamos ver o que você vai fazer. $O$ que você não tem na sua formação. Olha, você vai ser mestre ou doutor em saúde pública, tem que saber o básico pelo menos.

O caráter obrigatório, não flexibilizando a composição do programa de estudos, não dá especificidade entre experiência e conhecimento do aluno, e a necessidade de aprendizado e tema de pesquisa que pretende desenvolver. Isto parece ser mais grave para os alunos que já fizeram especialização em saúde pública e que estão trabalhando na área. Eles em princípio não se sentem desatualizados no conhecimento básico de saúde pública, mas sentem necessidade de avançar em conhecimento, e de refletir sobre sua prática, por isso procuraram outro nível de curso.

(5A) Primeira coisa, fui obrigada ... sendo que eu fiz curso de saúde pública lá ... então fui fazer de novo epidemiologia, sociologia ... sabe ... Apesar da diferença de tempo entre um curso e outro (...) olha, eu vou te dizer uma coisa ... eu seria idiota se dissesse que não houve, que eu não 
acrescentei coisas ... é claro que acrescentei ... O que eu questiono é o custo e benefício disso assim ... Eu poderia ... acho que na fase que estou da minha vida ... depois de trabalhar muitos anos em serviços ... de estar sempre acompanhando lendo coisas, eu acho que eu poderia aproveitar esse meu tempo melhor ... Poderia acrescentar essas coisas e de uma outra forma ... sem querer ser pretensiosa ... mas assim ... eu achei que é perda de tempo ... que deviam me dar essa liberdade de montar ... já no primeiro ano, a minha grade ... em função do meu interesse. Então, esse já foi o primeiro problema que eu achei no primeiro ano de mestrado ... ser obrigada a fazer aquelas coisas obrigatórias ... com total desprezo pelo meu curriculum e tal ...

Um outro aspecto é que as disciplinas obrigatórias ocupam um semestre com aulas de $2^{\mathrm{a}}$ a $6^{\mathrm{a}}$ feira. Para quem não está liberado do trabalho para fazer a pós-graduação, fica difícil concluí-las no primeiro ano. A solução de parcelamento em dois anos, provocava provavelmente um alongamento do curso e como atualmente o prazo total para conclusão é de três anos, o parcelamento parece impossível.

Quanto ao conhecimento prévio, assim se manifesta um professor.

(6P) ... o que os alunos colocam é assim ... ele tem ... não tem formalmente a disciplina, mas ele tem uma experiência de saúde pública que dá para ele esse conhecimento. E isto não é uma coisa considerada (...) o que a gente pode até trabalhar é se o aluno acha que ele não precisa, que os alunos sempre acham, né, e na hora que você aperta não é bem assim. Ele sabe tudo de metodologia, mas na hora que você pega os projetos você chora, né. ... é que o nosso aluno exige muito. você pega qualquer curso europeu e é super estruturado, tem que fazer isso ... gostou ou não gostou ... e está aí, o curso é este, independente do nível que você tem. Você vai para lá e tem que fazer isso, pode ter 10 milhões de repetições, não importa. O curso é esse, não dá nem oportunidade de discutir. Mas vamos imaginar que você possa ser mais flexível, né ... aquele que traz documento que fizeram cursos semelhantes em outros lugares, a Comissão analisa, o professor analisa e dispensa ou não (...) aquele que traz da prática seu conhecimento estruturado, então se submete a um exame ... faz uma prova ... Essa é uma alternativa, né ... .

Para os professores que ministram as obrigatórias essa é uma tarefa bastante difícil, uma vez que se trabalha com um grupo bem heterogêneo; estando exclusivamente a cargo deles a definição do conteúdo a ser desenvolvido. Para os professores que não têm essa missão, as obrigatórias são tidas como necessárias e interessantes, mas eles não chegam a se posicionar como se tivessem influência ou 
crítica a essa questão, realmente parece que o problema fica a cargo dos responsáveis pelas mesmas. Estes últimos são professores que se sentem recebendo o aluno após eles terem "resolvido o problema da informação básica".

Um dos professores responsáveis por disciplina obrigatória resume bem o desafio enfrentado por eles, trazendo uma angústia que não é trabalhada pelo conjunto de docentes

(2P) já que eu estou com uma disciplina obrigatória (...) uma das coisas que tem aqui, que eu digo da demanda, é que mesmo dividindo e espaçando você está com uma disciplina de pós graduação, que você tem que dar a aula para ... de 100 a 120 alunos (...) Se eu tivesse uma oferta de professores suficientemente grande, eu poderia dividir, mesmo essa distorção, chamemos assim, ela poderia ser sanada, você poderia dividir em turmas ... (...) então a primeira coisa da demanda é a quantidade que está havendo ... $E$ isso realmente num curso de pós graduação, praticamente impede, por exemplo, de você variar a tua estrutura e a tua estratégia pedagógica.(...) Uma outra coisa da demanda é a heterogeneidade. Como os pré requisitos da pós graduação mudaram, estão mais ou menos liberados, e tem muito aquele negócio que eu já falei antes, a questão do recém formado, às vezes muitos sem vinculação a trabalhos, etc, etc ... né ... você está enfrentando um desafio muito grande, sobretudo nas obrigatórias, né, se elas são obrigatórias é porque elas são básicas. Se elas são básicas tem que dar o conteúdo básico. Agora, esse básico, não necessariamente tem que ser superficial, é o básico dado de modo profundo.

Acontece que para você aprofundar o básico, onde você tem 100 ... 120 alunos, você tem essa heterogeneidade muito grande. Então, tem gente que você precisa começar quase do zero da concepção de trabalho em saúde pública. E tem outros, que mesmo não tenham pré requisito de ter feito curso, a pessoa já fez curso de especialização, já em experiência de serviço, já tem outros cursos, já tem um curriculum, já tem o acúmulo de conhecimento pessoal, está certo?, muito grande. Então, você fica na seguinte situação, de trapezista, se você eleva demais uma parte da turma não acompanha, e se você baixa um pouco o pessoal que está acima da média se desinteressa, está certo (...) Muito bem. Bom, tem gente que não sabe nem quando começou e o que é a reforma sanitária. E tem gente que fez a reforma. Certo? Então, como é que você equilibra isso? Tá?, está certo ... muito bem (...) A outra coisa também é a grande diversidade profissional, de experiências, que é salutar, mas também teria que ver como é que a gente poderia compor ou não ...

(...) Por isso que eu pergunto se ela é obrigatória geral, ou é obrigatória para quem, de que modo

Enfocamos mais a questão das disciplinas obrigatórias, mas em outros momentos também existem dificuldades para o diálogo entre as diferentes áreas, 
por exemplo, dificuldade de compreensão dos conceitos próprios de outra área. Não são resolvidos nas obrigatórias e a nosso ver nem deveriam ser, mas deveriam ser trabalhadas em todo o curso, à medida da necessidade.

(4P) a engenharia, falando como engenheiro. Por exemplo, um exemplo clássico. Nós tratamos de meio ambiente e não sabemos nada de ecologia. Nós nos maravilhamos quando olhamos o livro do professor Foratini. De uma certa maneira, trata de ecologia dentro da epidemiologia, mas com uma linguagem extremamente difícil para os nossos alunos de pós graduação, engenheiros. Está certo? O engenheiro nacional, o engenheiro brasileiro, de ecologia ele ouviu falar .. ele ouviu falar, há uma poluição conceitual em relação ao que seja ecologia. Parece que o grande público faz ecologia, estuda ecologia. Então, há uma falta grande de conhecimento aprofundado nesse setor.

Trabalhamos com advogados na área de gestão de meio ambiente. A legislação brasileira é extremamente forte, apesar de ser adaptação de legislação estrangeira, ela é forte. E muito difícil para os profissionais de pós graduação ... aparecem demandas, demandas relativas à interpretação da legislação brasileira, como utilizar os instrumentos da legislação para uma gestão eficiente, adequada do meio ambiente. Nossos alunos eles tem demonstrado um certo desconhecimento dessa área. Sentem uma dificuldade de não conhecer essa área. Acredito que todos escolhem seus temas, seus projetos de pesquisa dentro de uma área quase que preponderantemente de engenharia sanitária básica, saneamento básico, abastecimento de água, coleta e disposiçãa de esgotos sanitários. Muita coisa na área de poluição industrial, muitos dos nossos engenheiros são engenheiros industriais, conhecem bastante o processo industrial, entendem muito da área de poluição industrial, mas não sabem como esse problema de poluição se insere dentro do meio ambiente, do ponto de vista ecológico. Não sabem como a comunidade do entorno de qualquer fonte de poluição percebe essa poluição. $O$ engenheiro não sabe interpretar a percepção da comunidade de uma maneira geral, a não ser por características pessoais, que ele tenha um background que Ihe permita.

(2A) ... eu não tenho qualificação na área de direito, né, mas a minha tese mexe muito com isso, né, então embora eu não tenha ... sou muito clara nos limites do meu trabalho, ele mexe muito com a área de direito, assim ... estou trabalhando com normas jurídicas, né, mas não é a minha área. Então, eu estou buscando entender o meu campo dentro dessa amplitude, que inclui inclusive a área jurídica, né.

Concluindo este aspecto da pós-graduação consideramos que a FSP parece assumir uma concepção de formação em saúde pública baseada na figura do sanitarista generalista; buscando dar aos alunos, de forma homogênea esse conhecimento e não levando em conta os diferentes grupos de alunos existente, suas expectativas e necessidades. 


\subsection{DISCIPLINAS ELETIVAS}

Ao realizar as entrevistas deste estudo, alguns professores e todos os alunos se manifestaram em relação às disciplinas eletivas.

Os comentários dos depoentes, quanto às disciplinas permitiram o destaque de três aspectos desse processo: a composição do programa de estudo com a escolha das disciplinas; a articulação das disciplinas entre si e com o tema de pesquisa escolhido, e a dinâmica na sala de aula.

Ao iniciar o curso o aluno deve apresentar um programa de estudos com discriminação das atividades a serem cumpridas.

$\mathrm{Na}$ tentativa de compatibilizar a disponibilidade horária do aluno e os temas de seu interesse com as matérias oferecidas pela FSP ou por outras escolas, o primeiro passo é o de consultar a grade de disciplinas da FSP. A seguir apresentaremos as características desse quadro na FSP.

Segundo NUNES e COSTA (1997) há em todos os cursos da área de saúde coletiva do país um número elevado de disciplinas opcionais abordando temáticas diversas. O elenco de disciplinas na FSP é também bastante elevado, variando de 110 a 135 no período de 1990 a 1997, podendo se observar nesse período uma tendência a aumento. Os professores do Departamento de Prática de Saúde Pública e o de Epidemiologia ministram cerca de 57\% dessas disciplinas (Tabela 10).

Para o ano de 1998, a responsabilidade por disciplinas é basicamente dos professores que estão na ativa na FSP (86,9\%), 11,9\% são de professores aposentados, sendo que a maioria dessas últimas disciplinas não está sendo oferecida. Seis orientadores externos à FSP oferecem disciplinas na área de SA, correspondendo a $28,7 \%$ das disciplinas dessa área, que possui a maior proporção de orientadores externos. Com exceção de $7(7,6 \%)$ as disciplinas têm um único responsável.

Considerando os títulos das disciplinas, podemos afirmar que os temas 
abordados são bastante diversos, e como poderíamos supor a partir dos Anexos 1 e 2 comentados na introdução deste trabalho, referentes à quantidade e diversidade existente na FSP de temas de cursos e de linhas de pesquisa. Lamentavelmente não pudemos trabalhar com o conteúdo programático das disciplinas uma vez que os programas registrados na Seção de Pós-graduação estão, na sua grande maioria, desatualizados, não correspondendo à realidade do que é desenvolvido com os alunos.

A observação abaixo foi uma das que nos conduziu a identificar a dinâmica da oferta de disciplinas eletivas na FSP, que interfere diretamente na escolha dos alunos.

$(5 P)$... eu acho também que a Faculdade tem um conjunto de disciplinas que não ... que vem se renovando muito lentamente. E tem uma oferta muito ... quer dizer, não é só uma oferta em termos de temas, mas é uma oferta muito restrita em termos de horário, tem um aspecto que é até burocrático inclusive que é um fato assim: você vai escolher e de repente as disciplinas são oferecidas todas de manhã ou todas à tarde, então o aluno fica com uma camisa de força, porque se ele escolhe uma, ele só vai poder escolher daqui a um ano porque elas são oferecidas no primeiro, ou no segundo semestre ... então, quer dizer, tinha que trabalhar essa questão do horário, para não falar da questão dos temas, mas a questão do horário da disciplina. Uma maior padronização em termos de número de créditos, enfim ... olha ... eu vou ter disciplinas de 3 ... 6 ou 12 créditos ... alguma ... no sentido de tornar mais fácil a escolha. Que a escolha de uma não exclua a escolha de outra, porque tem acontecido isso em termos de horário

Ao analisarmos as grades horárias observamos que muitas disciplinas não são oferecidas regularmente, o que ocorre de maneira semelhante em todos os departamentos da Faculdade, com cerca de 30\% das disciplinas não sendo oferecidas anualmente (Gráfico 10 e Tabela 10). 
Tabela 10 - Pós-Graduação Stricto Sensu FSP/USP

Disciplinas eletivas segundo departamento e oferecimento ou não da disciplina

1990 a 1997

\begin{tabular}{|c|c|c|c|c|c|c|c|c|c|c|c|c|c|c|c|c|c|c|c|}
\hline \multirow[t]{2}{*}{ ANO } & \multicolumn{3}{|c|}{ HSP } & \multicolumn{3}{|c|}{ HEP } & \multicolumn{3}{|c|}{ HSA } & \multicolumn{3}{|c|}{ HSM } & \multicolumn{3}{|c|}{ HNT } & \multicolumn{4}{|c|}{ TOTAL } \\
\hline & Of. & NOf. & Sub T & Of. & NOf. & Sub T & Of. & NOf. & Sub T & Of. & NOf. & Sub T & Of. & NOf. & Sub T & Of. & NOf. & Total & $\%$ NOf \\
\hline 1990 & 28 & 11 & 39 & 16 & 5 & 21 & 16 & 8 & 24 & 10 & 3 & 13 & 8 & 5 & 13 & 78 & 32 & 110 & 29,09 \\
\hline 1991 & 24 & 11 & 35 & 16 & 12 & 28 & 18 & 7 & 25 & 11 & 2 & 13 & 4 & 9 & 13 & 73 & 41 & 114 & 35,96 \\
\hline 1992 & 28 & 8 & 36 & 23 & 8 & 31 & 17 & 8 & 25 & 10 & 3 & 13 & 10 & 3 & 13 & 88 & 30 & 118 & 25,42 \\
\hline 1993 & 26 & 9 & 35 & 27 & 10 & 37 & 18 & 8 & 26 & 11 & 2 & 13 & 11 & 3 & 14 & 93 & 32 & 125 & 25,60 \\
\hline 1994 & 23 & 12 & 35 & 29 & 8 & 37 & 17 & 9 & 26 & 12 & 2 & 14 & 8 & 6 & 14 & 89 & 37 & 126 & 29,37 \\
\hline 1995 & 22 & 15 & 37 & 29 & 10 & 39 & 18 & 10 & 28 & 10 & 4 & 14 & 9 & 5 & 14 & 88 & 44 & 132 & 33,33 \\
\hline 1996 & 26 & 11 & 37 & 30 & 10 & 40 & 22 & 7 & 29 & 9 & 3 & 12 & 8 & 4 & 12 & 95 & 35 & 130 & 26,92 \\
\hline 1997 & 19 & 20 & 39 & 27 & 7 & 34 & 20 & 8 & 28 & 8 & 4 & 12 & 7 & 5 & 12 & 81 & 44 & 125 & 35,20 \\
\hline TOTAL & 196 & 97 & 293 & 197 & 70 & 267 & 146 & 65 & 211 & 81 & 23 & 104 & 65 & 40 & 105 & 685 & 295 & 980 & 30,10 \\
\hline
\end{tabular}

*Das 27 disciplinas a serem oferecidas no ano de 1997, sete (25,9\%) ainda estavam para ser confirmadas quando a grade horária foi divulgada.

Legenda:

Of. - disciplinas oferecidas

NOf - disciplinas não oferecidas naquele ano.

In: Martins CL Vasconcellos MP da C, 1997. 
Julgamos oportuno ilustrar a situação da oferta de disciplinas trazendo dados, do Departamento de Prática de Saúde Pública. Esse Departamento realizou, em setembro de 1997, um seminário interno em continuidade ao seu processo de revisão/reformulação departamental, desencadeado pela avaliação departamental da Universidade, com o objetivo também de contribuir para uma possível revisão da pós-graduação da FSP. O documento base para discussão no seminário trouxe para reflexão dados sobre as disciplinas de pós-graduação stricto sensu do

\section{Gráfico 10 Pós-Graduação Stricto Sensu FSP/USP Disciplinas oferecidas e não oferecidas segundo ano 1990 a 1997.}

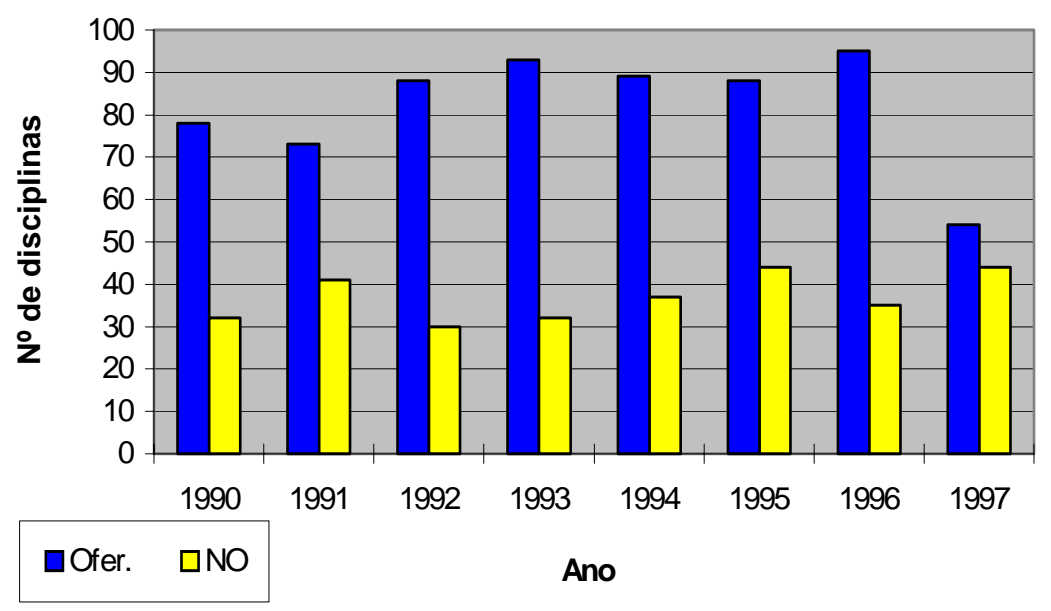

Departamento ${ }^{37}$, tendo como referência levantamento efetuado a partir da grade horária e das folhas de freqüência das disciplinas no período de 1990 a 199738.

\section{In:MARTINS CL e VASCONCELLOS MP, 1997 Fonte:Seção de Pós-Graduação FSP/USP}

O Quadro 4 mostra para esse Departamento a distribuição no período de 1990 a 1997, da oferta ou não de disciplinas, podendo-se observar que algumas em oito anos foram oferecidas poucas vezes. A existência de uma norma que diz que após dois anos sem ser oferecida a disciplina será extinta, parece não ser acionada nem pelo departamento e nem pela CPG, dando a impressão que não existe controle sobre essa situação.

37 Estudos da Comissão para assuntos de pós-graduação como subsídio à participação do HSP no processo de revisão e reformulação da pós-graduação. Julho, 1997.

38 MARTINS CL e VASCONCELLOS MP Mapeamento do Departamento de Prática de Saúde Pública, 1997. 


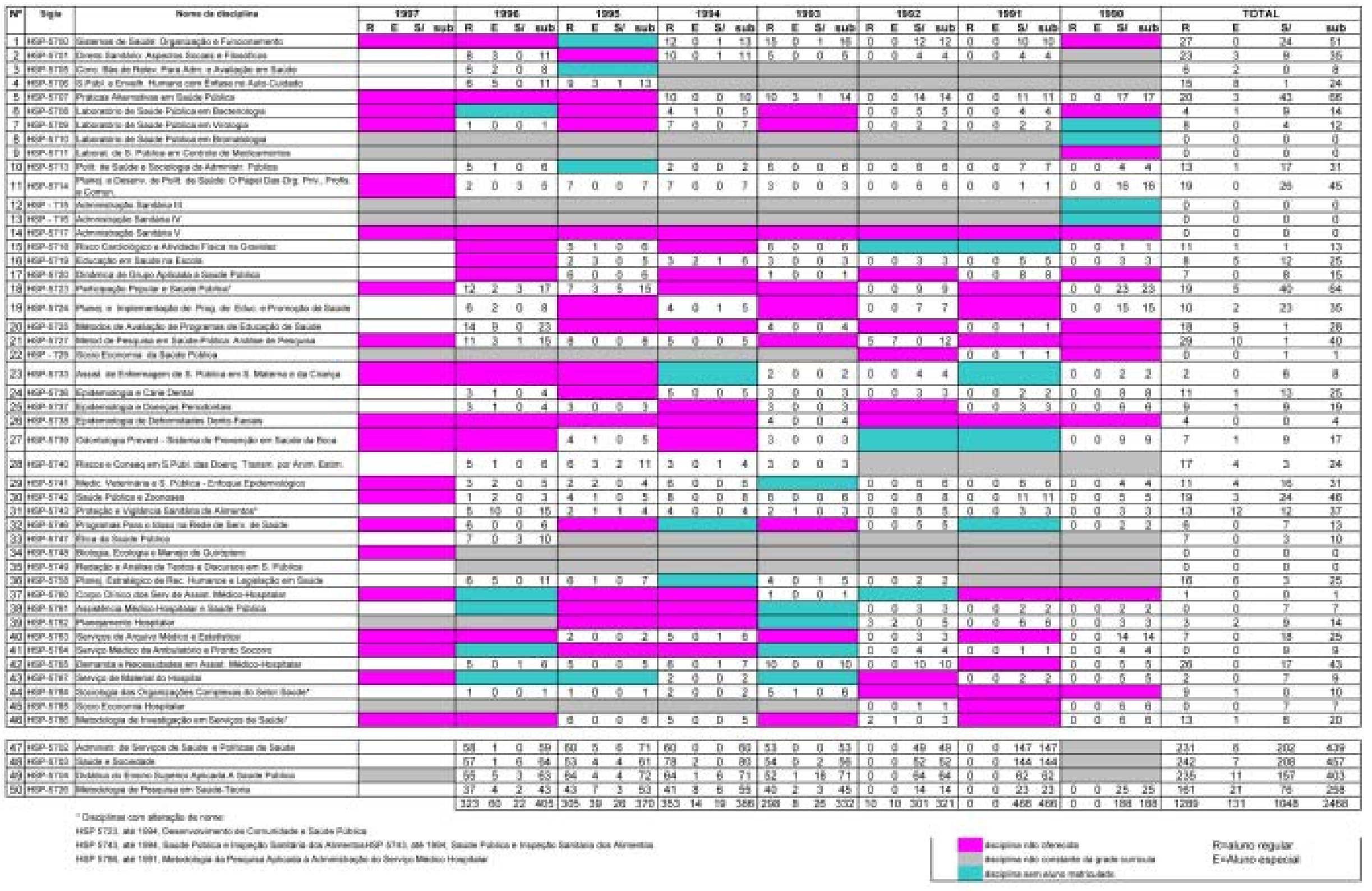


As disciplinas, ao serem oferecidas, nem sempre são freqüentadas, 0 estudo referente ao Departamento de Prática mostrou que de um elenco de 37 disciplinas, 31 da área de SSP e 6 da AH, só 21 foram efetivamente realizadas, sendo respectivamente 20 e uma (Gráfico 11).

O número médio de alunos por disciplina é bastante variado, no mesmo Departamento esteve entre 0,33 e 16 no período de 1990 a 1996, sendo que a grande maioria das disciplinas foram freqüentadas por menos de 6 alunos. Por outro lado, as disciplinas obrigatórias têm em média mais de 70 alunos em sala.

Outro aspecto apontado no trecho de depoimento anterior diz respeito à irregularidade do número de créditos das disciplinas. Para o quadro da FSP elas variam em torno de 2 a 10 créditos, sendo que em 1990 a maioria $(43,8 \%)$ possuía entre 3 e 4 créditos, em 1998 já se observa maior concentração em $6(25,0 \%)$ e 8 créditos (29,3\%). Apenas duas disciplinas possuem 10 créditos.

Gráfico 11 - Pós-Graduação Stricto Sensu FSP/USP

Disciplinas do HSP por área de concentração e ano, 1990 a 1996

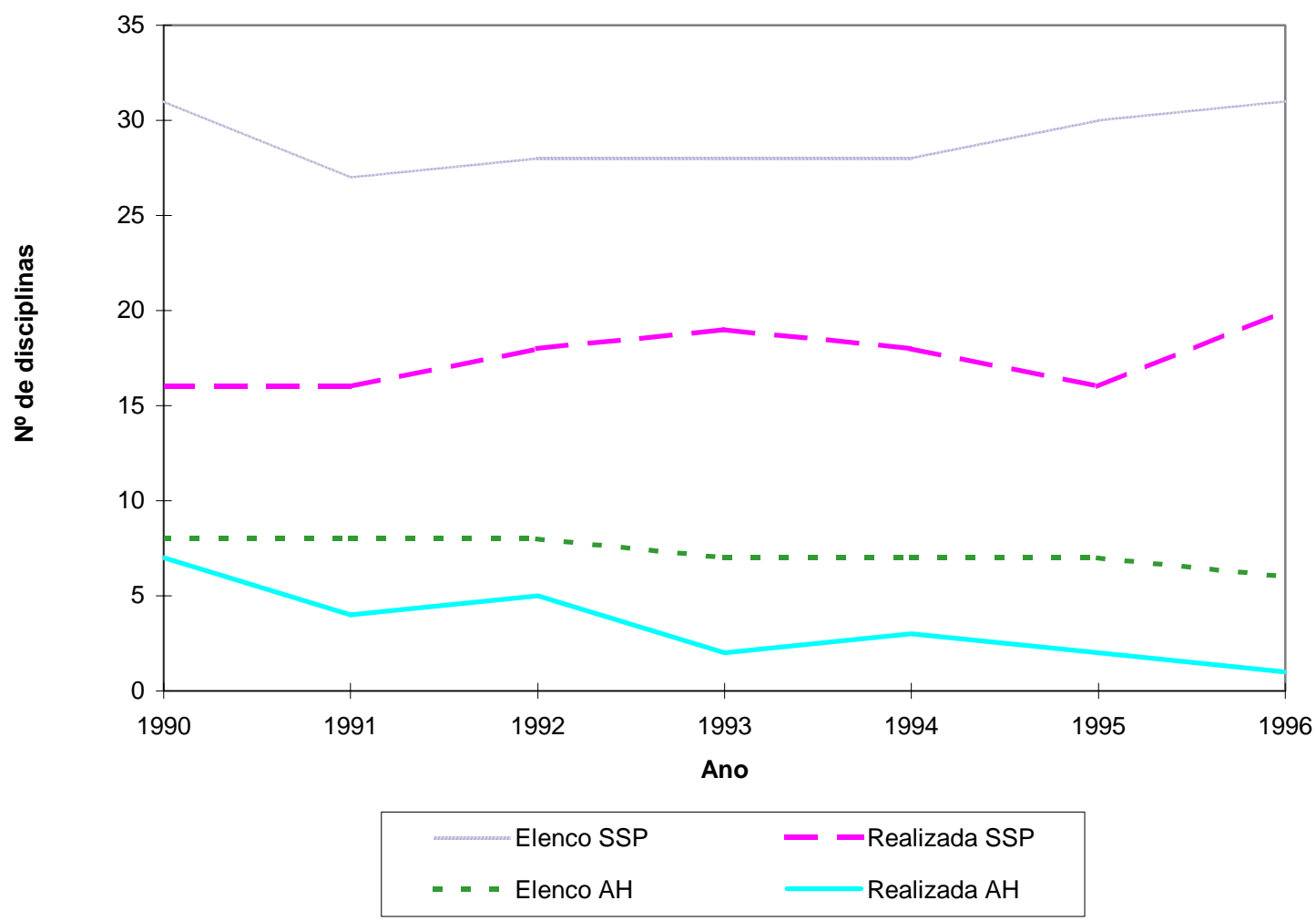


Com o objetivo de verificar a tendência de distribuição horária das disciplinas comparamos as grades curriculares de 1990, 1994 e 1998. O Anexo 6 apresenta quadros com a síntese das grades horárias desses anos.

A organização das disciplinas quanto ao dia da semana, período do dia e meses em que são ministradas não tem nenhuma regularidade. Isto talvez possa dificultar um bom aproveitamento do ano escolar, pelo observado em outras escolas parece que esse tipo de cronograma foge do usual.

A maioria das disciplinas acontecem às terças e quintas feiras, existindo 15 composições diferentes de dias da semana para ministração das aulas. Chamamos à atenção para algumas composições de horário que em princípio poderiam prejudicar ou restringir as possibilidades de formação do programa de estudos do aluno. Disciplinas ministradas só no meio do semestre com aulas de segunda a sexta feira apenas por uma semana: podem induzir o aluno a faltar em outra disciplina nessa mesma semana, mas ao mesmo tempo este horário talvez pudesse propiciar sua participação ao facilitar o afastamento do serviço; segunda e quinta, quando a maioria das atividades com que as pessoas se envolvem têm uma certa regularidade entre dias pares e ímpares da semana. A área de concentração materno-infantil por exemplo tem apenas 8 disciplinas sendo três às terças e quintas de manhã e três às terças e quintas à tarde.

Observamos uma tendência de mudança das aulas do período da manhã para o da tarde. A CPG nos últimos anos tem orientado os professores a evitar o período da manhã porque as disciplinas obrigatórias foram distribuídas ao longo do $1^{\circ}$ semestre de manhã. Existe portanto uma mudança entre 1990 e 1998 de concentração à tarde. As disciplinas eletivas em 1990 eram em 53\% dos casos ministradas no período da manhã, passando a $26 \%$ em 1998. Para este ano, $63 \%$ das disciplinas do primeiro semestre e $52 \%$ do segundo ocorrem à tarde. Horários de certa forma alternativos, como das 17 às 20 horas não são freqüentes mas a nosso ver seriam bem aceitos pelos alunos; duas novas disciplinas foram criadas nesses horários, e uma já ocupa esse espaço com número grande de alunos freqüentando. Seria conveniente acompanhar esse processo, avaliando a questão. 
Existe um equilíbrio entre o número de disciplinas oferecidas no primeiro e segundo semestre, considerando o conjunto de disciplinas dos cursos. Dois departamentos não possuem esse equilíbrio, são os de Epidemiologia, com sete no primeiro e 16 no segundo, e Materno-Infantil com oito e três respectivamente. Talvez isto se deva ao fato dos professores do HEP ministrarem disciplinas obrigatórias no primeiro semestre e reservarem o segundo para as eletivas.

É rara a disciplina que ocupa o semestre todo. Os meses com maior número de disciplinas sendo desenvolvidas são os de: abril e maio; e setembro e outubro. Apenas uma disciplina ocorre no mês de julho e de maneira concentrada, neste caso parece uma boa opção para o aluno que trabalha e não tem liberação para fazer a pós-graduação.

Esta situação descrita parece indicar que o curso está centrado no professor, e não no conjunto de docentes e nem no aluno. Parece que não se considera, por exemplo, a necessidade de substituição de professor por questões pessoais (as disciplinas tem um único responsável). Disciplinas concentradas poderiam ocasionar excessivo número de faltas caso o aluno apresente alguma intercorrência.

Enfim, ao montar seu programa de estudo o aluno se depara com uma relação de disciplinas, com temas variados e aparentemente grande quantidade de oferta, porém eles têm dificuldade para escolher as matérias que freqüentariam, pela não existência de harmonia dentro da mesma área temática em termos de horários e dias de oferecimento das disciplinas, bem como regularidade de oferta.

Os alunos declaram ser importante no momento da escolha das disciplinas, o horário em que as mesmas são oferecidas, não só para evitar acúmulo de disciplina mas para ser compatível com o horário de trabalho, e permitir a conclusão dos créditos disciplinares.

(3A) ... eu escolhi essa disciplina porque tinha muitos créditos ...

(4A) Mas eu achei que no primeiro semestre tinha pouca matéria que eu poderia fazer e no segundo tinha muitas. Então, eu fiquei ... assim ... no segundo semestre tinha assim umas três matérias que eu poderia 
fazer ... todas matérias vinculadas ao trabalho que eu faço, mas aí

complicava por esse lado do treinamento (no local de trabalho)

A escolha das disciplinas, para alguns alunos parece ser mais influenciada por informações recebidas de colegas do que pelo próprio orientador.

(5A) ... fazendo a disciplina que os colegas indicam ... Assim ... são colegas com os quais você tem uma relação maior ... você tem uma maior afinidade ... que você ... eh ... tem uma característica, um ponto de vista, uma ideologia parecida ... Então, aí fulano falou - fiz tal coisa e foi legal -, - ah ... tá bom ... vou me inscrever naquela coisa ... -.arriscar ...

Alunos da FSP, segundo as normas do curso podem fazer até um terço dos créditos disciplinares fora da USP. Não foi possível por não disponibilidade dessa informação consolidada, identificar quantas e quais são as áreas e escolas procuradas. Porém, o estudo realizado por MARTINS e VASCONCELLOS (1996) mostrou para o período de 1990 a 1994 que a escola mais procurada pelos alunos fora da FSP e dentro da USP é a FM/USP, correspondendo a 32,55\% das disciplinas cursadas fora.

Cursar disciplinas fora da FSP é um processo às vezes estimulado pelo orientador mas como vimos, não são muitos os alunos que realizam disciplinas fora. Alguns apontaram dificuldades para esse processo, principalmente de acesso à informação sobre essas disciplinas.

(3A) Ah, outra coisa também, quando eu cheguei aqui, eu não sabia que existia, do outro lado da rua, a medicina preventiva ... e que tinha um perfil nessa linha ... que a gente pode discutir ... tem matérias ... disciplinas muito interessantes ... como a da $A$. C. ... eu fiquei sabendo disso quando já tinha o meu plano feito ... praticamente já no segundo semestre ... E aí fiquei que no doutorado vou fazer algumas, mesmo que seja só como ouvinte, só para mim, mesmo que não tenha valor acadêmico ... em termos de créditos, né ... então vou pensar ... eu podia entrar lá e aqui ... lá eu pegaria a discussão conceitual e aqui a estatística que eu vou precisar.

(5A) ...trabalhando e fazendo mestrado, não tinha condições de sair garimpando em outras faculdades algum curso legal. Cheguei até a fazer uma tentativa de inscrição num curso na preventiva ... na área de planejamento, mas aí perdi prazo, não consegui fazer ... né ... por conta de eu não estar a disposição o tempo todo e não poder ficar garimpando curso e descobrindo ... e indo atrás ... então fiquei muito dependente da 
faculdade. E aí na faculdade fui obrigada a fazer ... o que dava para fazer ... Se você pegar minha grade, você vai ver, que tem cursos feitos na materno-infantil, tem curso feito na epidemiologia ... na epidemio acabei nem fazendo porque não deu certo, eu até ia fazer ... mas aí ... com a coisa dos horários não deu certo e terminei não fazendo. ... E no departamento de prática eu fiz o que eu tinha que fazer ... sai pensando assim e fazendo ... então ... eu fiz os cursos assim ... quer dizer, montei 90 créditos na marra.

Durante a entrevista apenas um professor se referiu ao estímulo que ele dá ao aluno para procurar outras escolas.

(5P) ... geralmente você sugere ou o aluno traz também sugestões ... olha, o aluno tem ido buscar, eu acho que tem partido muito da iniciativa do aluno vir discutir a disciplina, mas é uma iniciativa que eu estimulo, quer dizer, eu tenho estimulado. Estou lembrando, quem começou esse ano, esse último ano, eu falei - olha, mais ou menos com o tema, passe na preventiva, passe na PUC -, então estava ligado, tinha uma interface com saúde mental então - olha, passa na PUC, na psicologia, na antropologia -, quer dizer, dei umas dicas mais ou menos, vão atrás do programa, dos programas e aí a gente discute em cima do programa ... quando a ementa do programa também é vaga, a gente procura orientar ou falar com o professor ou procurar alguma informação mais específica ... do que vai ser dado no curso. Então, tem sido desse ... tem sido dessa forma.

Mas eu parto do princípio que você está na universidade e que você vai buscar, quer dizer, as possibilidades, os recursos da universidade enquanto instituição, para poder fazer o programa das disciplinas. E para isso contribuir para o projeto.

O processo de escolha descrito pelos alunos revela suas expectativas em relação ao curso, e como vimos existem expectativas diferentes conforme o grupo de alunos.

O interesse de alguns alunos está também voltado para atualização e formação em saúde pública, a pesquisa seria uma meta a médio prazo. São alunos de mestrado e não manifestam claramente a intenção de realizar carreira universitária. Estão preocupados também em retornar aos seus serviços com um corpo maior de conhecimentos. Tem um interesse mais difuso.

Neste caso o aluno procura disciplinas que completem sua formação ou que eles gostem independentemente da aproximação com a pesquisa. Imaginamos que talvez este seja mais um fator que contribua para o aumento do tempo de 
conclusão da pós-graduação.

(7A) Eu gostei das disciplinas que eu fiz ... eu gostei das disciplinas (...) no primeiro e segundo semestre, eu me dirigi para o tema. O semestre passado eu abri mais ... dentro do que eu podia compatibilizar com os horários, dias e tudo mais, eu falei - vou fazer isso porque eu gosto, isso eu quero aprender, independente de servir ou não para a pesquisa Aliás, se eu tivesse tido mais tempo, eu teria aberto para mais coisas que eu não fiz, e que eu gostaria de fazer. E que talvez eu ainda venha fazer, sim ... se for possível, eu não sei se eu posso, mas pelo menos como ouvinte. ... cursar determinadas disciplinas ... porque eu sei que são ricas e que vão me enriquecer para qualquer trabalho, vão me enriquecer como profissional. Acho que nunca nada é perdido ... nenhuma disciplina ...

(10A) Mas eu montei pensando no eu queria também ... porque eu estava buscando, não só para a tese, mas que complementasse meu trabalho, eu queria alguma coisa que me desse mais base para o trabalho que eu fazia. Por isso que fiz bastantes coisas de epidemio ... fiz na materno infantil, também fiz, mas fiz bastante de epidemio porque estava buscando isso.(...) Eu fui para aprender ... eu queria aprender um monte de coisas, então eu aprendi um monte de coisas porque eu queria aprender.(...) eu fiz mais créditos do que pedia...

Este último é o depoimento de uma aluna que está no mestrado tendo o primeiro contato com saúde pública, parece natural que o seu interesse seja mais abrangente, uma vez que um de seus objetivos é conhecer a área de saúde pública.

A preocupação com a oportunidade de atualização não é só do corpo discente, o conceito de mestrado elaborado para a discussão em Oficinas de Trabalho/ABRASCO e apresentado a seguir ressalta como uma das características do mestrado "a reciclagem e atualização de conhecimentos". Um dos quatro documentos elaborados por um grupo de professores ${ }^{39}$ da área, como subsídio para a Oficina de Trabalho "Avaliação da Pós-graduação Stricto Sensu em Saúde Coletiva", promovida pela ABRASCO, em agosto de 1997, tinha como objetivo discutir as modalidades de formação pós-graduada na área, tendo assim conceituado mestrado.

39 ELIAS PE e col. Memória da reunião realizada em São Paulo em 22 e 23 de julho/97 pelo grupo de trabalho encarregado de articular as modalidades de formação pós-graduada na área de saúde coletiva - São Paulo; 1997 [Relatório] 
"Modalidade de formação pós-graduada mais difundida em saúde coletiva até o momento, tem como clientela preferencial o pessoal de serviço com experiência profissional prévia e aqueles que pretendem seguir a carreira docente. Caracteriza-se por oferecer oportunidades para reciclagem e atualização de conhecimentos, bem como para sistematização de experiências/questões oriundas da vivência profissional, subsidiando assim 0 aperfeiçoamento do trabalho desenvolvido nos serviços de saúde e se constituindo em espaço para geração de projetos de pesquisa para o doutorado.

O objetivo principal do mestrado é o de habilitar profissionais cientificamente capacitados a interpretarem o núcleo saúde/doença em sociedades concretas, ao mesmo tempo em que fornece um tipo de treinamento ao aluno voltado para interação com a realidade, favorecendo assim o processo de mudança social".

Questionamos se este seria o nível de curso onde isto poderia acontecer. Para a CAPES o mestrado tem o caráter de desenvolver e aprofundar a formação adquirida na graduação, com vistas ao preparo para a função de docência e pesquisa.

Dependendo do aluno o interesse pelas disciplinas está mais voltado para o tema da pesquisa, é o caso dos alunos que já vem com projeto de pesquisa definido, ou se inserem na linha de pesquisa de seu orientador. São muitas vezes alunos que pretendem, por exemplo iniciar doutorado após o mestrado; tem perspectiva de realizar carreira acadêmica; que tem pressa em terminar a pósgraduação, porque a liberação do trabalho é pequena; e os que já estão no doutorado.

(2A) ... então, as disciplinas, eu ... buscava, em cada uma delas, encontrar subsídios para o meu objeto de estudo Nigilância Sanitária). E ... não foi muito fácil, eu te confesso, porque na medida em que essa área não é trabalhada, então nos curriculum das disciplinas, também a gente praticamente não tem conteúdos que se aproximem dessa área. Então, eu busquei aquilo que era possível, inclusive eu fui até em outras unidades, da USP, buscar também outras disciplinas mas nada encaixava muito (...). As disciplinas da veterinária já conheço pela minha formação, né, então ... como eu não ia especificar um trabalho ... aí essa questão da profundidade que eu te falei, quer dizer, não ia 
aprofundar a questão de medicamentos, nem questão de alimentos, nem alimentos de origem animal, nem outro tipo de alimentos ... então, as disciplinas dessas outras unidades não se adequavam muito. Então, eu fiz disciplina da medicina preventiva, e as disciplinas daqui, aí eu completei os créditos dessa forma.

(4A) E fui vendo as matérias que poderiam acrescentar alguma coisa ao trabalho, fiz epidemiologia 1 para essa parte de estratificação de causas e estou fazendo assim aos poucos. (...) olha, na verdade 0 primeiro semestre foi um pouco difícil. A S. já estava cancelando a matéria dela, o J. já não estava oferecendo a matéria. (...) é, porque as outras matérias eram muito assim ... quase que voltadas para a área médica e que não serviam muito para mim ou que seriam muito difíceis de fazer.

Os conteúdos disciplinares nem sempre constituem uma contribuição à compreensão do tema de pesquisa, mesmo para os alunos que conscientemente buscam isso. As linhas de pesquisa não são claramente definidas na FSP e as disciplinas não guardam relação com as linhas portanto dificilmente os alunos se sentiriam contemplados. Parece existir realmente duas fases - cumprir os créditos disciplinares e fazer a pesquisa.

(5A) Eu vi coisas de "a a z", agora não estou conseguindo utilizar essas coisas de "a a z" para desenvolver minha tese. Tenho que me virar um pouco agora ... sozinha, com orientador ... e estudar a tese. Ou seja, o que eu quero dizer é o seguinte: o tempo de estudo que devia ter me preparado para fazer a tese, terminou sendo um tempo de estudo para completar créditos ... fica bem claro aí para você ... então assim, foi um tempo de estudo para completar créditos ... não foi um tempo de estudo para aprimorar minha reflexão e fazer minha tese. Agora, terminei aqueles créditos, já resolvi aquilo que me importunava, que era minha obrigação, de ter " $x$ " créditos ... e agora eu vou junto com meu orientador estudar para fazer a tese.

Outro aspecto do programa de estudo é a "mistura" entre especialização, mestrado e doutorado, não havendo diferenças significativas entre as disciplinas ministradas a esses grupos. Retornamos a tênue distinção entre especialização e mestrado na FSP, como OLIVEIRA (1995) reconhece ser um problema para todos os cursos de pós-graduação.

(7A) ... e você não aproveitou as disciplinas do curso da especialização? Você começou de novo? é ... isso ... tem isso também ... O curso de especialização, alguns professores, também não é critério geral, não é norma geral na Faculdade, alguns professores aproveitam a disciplina 
que você faz, sem contar o tempo ... sem retroagir no tempo ... Epidemiologia faz isso, epidemiologia 1, bioestatística faz isso, e é muito legal, considera sua nota e sua freqüência. E mesmo assim eu vim assistir aulas ... mesmo não tendo obrigatoriedade de cursar. Agora, outras disciplinas, como Saúde e Sociedade, Políticas ... retroagem no tempo, então não valeria a pena para mim, que estava tendo um ano de hiato entre a especialização e o mestrado, perder dois anos por conta de ... na época ... 11 créditos, não valia a pena. Então aí eu resolvi cursar de novo. Nada perdido, claro que não, mas eu fui tentar conversar com os professores, pessoalmente e vem as desculpas ... as mais diversas. Jogam a responsabilidade ... nunca sobre si, - não, mas eu quero que você faça porque eu quero que você faça -, ninguém é claro assim - não, mas é porque é outro conteúdo -, ou - é o Departamento que pede ... é diferente ... -, nunca é o professor que determina por si só, né. Então, eu fiz. E ... tudo bem ... depois que abaixou ... tudo bem ... agora, 0 conteúdo não é tão diferente assim ...

(2A) ... peguei uma disciplina da área de direito sanitário, que era do curso de especialização, então eu fiz essa disciplina.

(9A) das eletivas ...uma o professor me dispensou porque eu já havia feito na especialização.

O envolvimento do aluno com a realização das disciplinas dessa forma correndo atrás dos créditos, estudando temas diversos -, favorece a um afastamento do orientador. Como se realmente a orientação fosse ter início apenas na hora de fechar o projeto e fazer a pesquisa.

(9A) ... nessa fase de créditos o contato foi pequeno, né, mas de vez em quando a gente se cruzava lá pelos corredores do Departamento. Agora na fase do projeto aí eu fui lá várias vezes.

SEVERINO (1993) fala sobre o “... abismo entre o momento vivido pelos pós-graduandos enquanto cursam as disciplinas do regime curricular dos programas e o momento seguinte em que deveriam dar andamento a sua pesquisa com a ajuda do seu orientador. A falta de ponte entre esses dois momentos é a explicação das dificuldades...".

Percebemos que na FSP existe esse abismo. A separação entre os dois momentos é bastante acentuada. No mestrado, cursar as disciplinas também pode se dividir em dois momentos - as obrigatórias e as eletivas. $\mathrm{O}$ abismo pode ser um dos fatores que ocasiona a demora no término do curso, lembramos ainda que a 
evasão vem ocorrendo em metade dos casos depois que as disciplinas foram concluídas e os alunos deveriam apresentar projeto de pesquisa (MARTINS e VASCONCELLOS, 1996).

(4A) ... o que seria mais interessante para mim seria ir um pouco mais depressa com a tese, né, porque aí eu tenho um pouco como conciliar o meu horário, né ... Os meus colegas que foram fazer no exterior, em geral já foram direto para a tese ... fizeram uma ou outra matéria para ajudar na tese ... mas no geral eles chegam lá e já vão partindo para a tese. Eles já começam logo a se dedicar à tese, né ... E acho que nesse ponto, o que eu estou vendo dos outros colegas, é que você acaba gastando mais da metade do seu tempo cumprindo créditos e aí você fica com dois anos ou até menos para fazer a tese (...). Aí você faz uma ou outra matéria com a vantagem de estar lá só para isso, né. Aqui só pode começar a fazer a tese quando concluir os créditos, né ...

$P:$ e você já tem idéia sobre o que você quer trabalhar?

R: um pouco, eu não planejei muito no detalhe até por causa disso ... como não era uma coisa muito a curto prazo ... mas o tema eu já pensei (...) Aqui também teve a vantagem de que ao mesmo tempo que tendo de cumprir alguns créditos, foram matérias que acabaram em termos do trabalho colaborando ... coisas que a gente ouvia dizer, que não sabia sobre o discernimento dela, né. Por exemplo classificação de causas. Agora o que complica um pouco é que às vezes você tem que ficar procurando a matéria porque não tem alternativa ... às vezes não tem muita escolha, né (...) Ajudando talvez não tanto em termos da tese, até talvez em termos da tese também. Mas ...

\section{A dinâmica na sala de aula}

Nos depoimentos os alunos falam de três aspectos da dinâmica das disciplinas: técnicas de ensino-aprendizagem, articulação das disciplinas entre si e conteúdo.

As "queixas" dos alunos em relação à condução das disciplinas não são generalizadas a todas as disciplinas, porém eles foram bem enfáticos ao fazer as críticas tanto para as disciplinas eletivas como para as obrigatórias.

(2A) Eu fico contente que a Faculdade esteja passando por um processo de reformulação onde entra a questão da qualidade do ensino. Então, eu tive uma experiência muito ruim com algumas disciplinas ... A qualidade muito ruim ... Assim ... não podia nem ser ... aquela qualidade não podia nem ser de graduação ... porque a graduação tem que ser ... quer dizer, o mesmo patamar de qualidade, tem que estar em todos os níveis, do 
primário, à pós graduação, nível de doutorado, quer dizer, a mais alta qualidade possível ... né.(...) teve situações assim ... um nível muito baixo ... muito baixo ... de conteúdo, de forma de lidar com aquele conteúdo ... de técnicas pedagógicas ... assim ... nos mais diversos aspectos ... E ... e isso é muito frustrante. Primeiro, porque a gente não tem mais tempo a perder ... com as coisas, neste mundo. Não temos na universidade ... não temos que estar fazendo pós graduação, você está cheio de exigências e você vai fazer uma disciplina buscando subsídios para você trabalhar ... e aí você vai e perde tempo ... ou então não tem resposta para aquilo que você produz, né, e é muito ruim. Então, você não tem interlocutor para aquilo que você produz ... De repente uma pessoa, um aluno de pós graduação, apresenta um seminário, e ele só recebe uma nota... é muito ruim ... mesmo que essa nota seja a máxima. Então, aqui é um espaço de discussão, né. Então, se você produz alguma coisa, tem que ter uma discussão sobre aquela sua produção, né. Acho que isso tem que ser dessa forma.

Quanto à técnica de aprendizagem, os alunos chamaram à atenção para as disciplinas compostas por aulas expositivas e com avaliação por meio de prova.

(7A) ... uns tem uma técnica, se eu posso falar que é técnica, melhor de trabalho com os alunos do que outros. Alguns até se preocupam com isto ... com este aspecto, da didática de ensino. E outros não. Outros discursam na aula ... você tem a sensação que você está ouvindo ... você está diante de um palanque ouvindo um discurso, uma plataforma.

(3A)... e eu tinha tantas expectativas (...) mas não foi assim ... era aula ... quatro horas ... escutando, escutando ... letra morta ... coisas sabidas ... entende?, coisas que não tem um valor, porque você não vai usar desse jeito que foram colocadas ... e aí é difícil, porque a capacidade de pensar criticamente ... é uma coisa importante em saúde pública.

(4A) ... fiz, epidemiologia ... Nós fizemos uma prova e uma semana antes estavam todos os alunos apavorados porque falavam que ia cair tal coisa ... até circulou tipo o que seria uma prova, com questões que a gente nem ... então estavam todos os alunos apavorados ... porque achavam que ia cair até coisa fora do que estava nos programas. (...) Tinha muita coisa assim. No CEDEPLAR a gente fez prova também mas no geral ficava de você fazer um trabalho final com aplicação daquilo que você tinha visto no curso. O professor falava - então, a gente viu isso, façam uma aplicação prática -. Porque às vezes dão cinco perguntas, você não consegue responder uma ... pronto ... você já não entrou no menor critério ... porque sempre tem aquela matéria que você aplica ... a área de interesse que você quer ... e aí você vai pelo lado que você trabalha, aí você pega os dados ... todos os dados, análise dos dados ... né ... e não fica aquela coisa de resposta de perguntas, né. 
Um recurso que parece ser comum é a presença de convidados, para ministrar palestras, porém nem sempre essas palestras são "amarradas" no conteúdo da disciplina. Os alunos queixam-se de uma desarticulação entre as disciplinas e entre aulas de uma mesma disciplina, indicando inclusive falta de planejamento didático do curso.

A expectativa de que as disciplinas pudessem conduzir a um processo reflexivo, problematizador, acaba sendo frustada, parece existir uma valorização da transmissão de conteúdo instrumental, com verificação do aprendizado por meio de provas.

(2A) E eu tive essa experiência, muito ruim ... de disciplinas assim ... ou de disciplinas muito dispersas, com muita gente participando ... e sem uma ligação, né, entre os tantos participantes ...... é, muitos professores, muitas palestras ... e cada um puxa para um aspecto, mas não existe nada que una aquilo tudo, né ... então teve situações de disciplinas muito ruins, que não parecia estar inserida numa pós graduação, numa Faculdade que tem tanta história ... né ... e foi uma decepção muito grande isso. (...) Então, eu acho que tem que ser trabalhado bastante, disciplina por disciplina ... e que os alunos possam falar, né, sem medo, né, porque às vezes ... às vezes a gente pode, nessa tentativa, se policiar muito com medo depois de conseqüências ... né ... ruins, na hora de um exame, né ... e acho que isso não deve tolher ... porque a gente não é criticar um professor, ou outro professor, mas criticar a forma como aquela disciplina está sendo conduzida ... e contribuir para que ele melhore isso, né, para que a gente possa avançar..

Então, na verdade, tem essa coisa da qualidade do ensino, que não é generalizável, acho que tem disciplinas muito boas, com um trabalho sério, construído por professores e alunos ... eu vivi essa experiência também. Mas eu vivi a experiência da negação total ... foi muito ruim, muito ruim mesmo.

(5A) ... curso mal estruturado, com conteúdo mal estruturado e que as pessoas parecem que fazem aqueles cursos assim ... - ah ... vamos fazer um curso? -, - ah ... tá bom ... então eu chamo a Cleide que fala um negócio aqui, chamo fulano ... -, e fez um curso ... sabe ... Não, o que é? Onde é que ele começa, onde é que ele acaba ... qual o papel da faculdade ... eu que coordeno o curso ... O corpo técnico da faculdade ... pode até ter um convidado ... não tem problema nenhum, mas assim ... eu vou trazer o convidado dentro de uma perspectiva " $x$ " ... vou dizer para ele o que eu quero dele e vou fazer uma amarração com meus alunos do que vai acontecer ... Esse é um exemplo dramático ... Então, acho que é um tipo de problema que acontece lá.(...)

... por exemplo, eu já fiz curso que eu achei bom lá ... que se trabalhou muito em cima de artigos, discussão, de material, né, de documentos, de 
livros ... de artigos atualizados sobre a questão e que foi distribuída, foi editada bibliografia ... que você pode ler, discutir, voltar e ter alguma coisa, deu um produto, né. Eu já fiz alguns cursos assim, pouquíssimos ... né. Mas assim, ou o curso é uma coisa igual a esse aí, desestruturado e com um conteúdo assim ... eu tenho a impressão que se você pegar esse curso durante vários anos, seria interessante ... pegue e veja para ver vários anos se ele tem uma linha comum assim ... A pessoa que dá fala assim - está na hora do curso!, oba!, então chama o fulano ... beltrano você pode dá ...um traz outro traz aula.(...) Então, fica assim ... vários assuntos ... Vários pequenos assuntos feitos ... parece esses cursinhos que você vai fazer assim ... para cumprir obrigação, vários assuntos dentro de um período que é um semestre, você dá um tempo pequeno para cada cursinho daqueles ... que é um assunto importante e que é tratado superficialmente por alguém que vem de fora ...

(...) Agora, escolhi alguns cursos que para mim foram bons ... né ... só que foram bons ... aquilo que eu falei, por exemplo, escolhi esse porque é um curso que eu vou ... vai ser menos ruim, vou ter a chance de fazer uma reflexão, uma discussão orientada e tal ... só que muitas vezes não era importante para o meu projeto de tese ... né.

(3A) Mas no sentido dos conteúdos, por exemplo, das disciplinas em geral ... eu acho elas muito boas ... só que acho que há muita desarticulação entre elas ... Estatística está aqui, epidemio está lá ... discutindo as mesmas coisas mas de forma desintegrada ... Você está falando de intervalo de confiança em estatística e em epidemio também ... mas aí não dá para fazer uma ponte ... não dá porque as disciplinas estão muito isoladas ... Eu acho que é pensar, um pouco integralmente em torno de qual é o objeto de estudo da epidemio, né ... qual o objeto de estudo de interesse das diferentes pessoas. Eu acho que seria mais interessante para montar um esquema de disciplina e aí esse modelo de disciplina obrigatória e tal acabaria, porque a gente montaria em função do seu interesse. O que me interessa? Mas as disciplinas em si deveriam estar montadas de forma coordenada, integradas, porque tem que ter uma ponte ... porque na verdade elas se separam muito. Você estuda estatística de um jeito, estuda epidemio de outro jeito, como se as duas coisas não estivessem relacionadas ... e na prática você usa elas juntas (...) seria importante ter uma visão crítica ... E na epidemio eu acho que também tem pouco espaço, um espaço pouco democrático para você dentro da aula colocar suas posições ... filosóficas, epistemológicas ... ou quaisquer que sejam elas ...

(3A) acho que nesse sentido cumpriram a função, só no instrumental. Agora, utilidade desse instrumental, como aplico esse instrumental ... nada ... aplicação ... essa ponte com a realidade ... Como aplico, como uso ele ... muito pouco ... foi muito pouco. E por outro lado a discussão sobre o que elas somam, a relativização delas ... o que elas são, o que elas representam ... qual suas limitações, muito pouco. E o que está por trás delas, ou seja, a teoria, paradigmas, o que está por trás delas ... e que implicações tem, muito pouco ... quase nada nessa área, né. Então, pode ser que esteja exigindo demais, pode ser que meu nível de 
exigência esteja um pouco fora do contexto, talvez ... mas eu sinto isso como uma necessidade ... e muita gente do meu grupo fala a mesma coisa, né, falam a mesma coisa ... Pelo menos é um desejo, uma expectativa coletiva, não é individual ... Então ... muita gente reclama dessa disciplina, essa separação, desintegração ... que é só ferramenta, instrumental ... você está acéfalo ... como se isso fosse a única coisa que existisse, entende ... - é o máximo, é o único ... -, e isso não é verdade ... Isso está descontextualizado ... e não tem uma ponte com a realidade, como é que eu uso isso ... A própria forma de ensinar isto é assim, muito conceitual ... e não sobre uma situação concreta ... e isso pode ser feito na sala de aula ... pode ser, não é difícil ...

Os alunos esperam algo que favoreça o desenvolvimento da capacidade de análise crítica - a disciplina propiciar a produção de um "paper" ou um ensaio que posteriormente possa ser utilizado na pesquisa ou mesmo que leve alguma contribuição a sua instituição de origem. Outra estratégia desejada seria a criação de espaços onde a discussão entre alunos e professores a respeito de temas de suas pesquisas fossem socializadas.

(2A) ... Mas alguma coisa que possa unir mais, né, que possa tornar mais conhecido o projeto de cada um, que possa ... que a gente possa saber mais do que está sendo feito na faculdade, quais as pesquisas que estão caminhando, quais os projetos de alunos da pós graduação ... e talvez com isso diminua esse distanciamento maior e uma certa desinformação sobre o que está indo em termos de produção de conhecimentos mesmo.

Eu sei que existem os mecanismos mais comuns ... das revistas ... e tal ... e tal ... mas eu acho que é um outro mecanismo, enquanto a coisa está se dando ...

Disso que eu sinto falta, sabe ... uma coisa mais viva mesmo ... mais dinâmica, nesse sentido do acompanhamento, do processo que está sendo vivido, experienciado ... experimentado.

(3A) ... o momento, exatamente, que eu acho que é isso o legal da disciplina ... inclusive eu acho que em cada disciplina a gente poderia produzir uma coisa útil para o que você faz ou para o que você se interessa ... Se você produz uma coisa útil, você pode publicar ... ou algo que pode ser usado na prática, isso é bom ... Acho que se as disciplinas fossem organizadas nesse sentido seria outra coisa porque aí sim tem espaço para problematizar (...). E se eu tenho essa conduta ao final de uma disciplina, pelo menos se não no final, intermédio ... depois você continua ... e isso é legal, porque aí você se dispõe a discutir, falar ... Mas como é o jeito aqui, ensinar conteúdos, são letras mortas que você não integra com a realidade ... Para que serve para mim aprender a média da divisão standard? 
Em síntese a análise do desenvolvimento das disciplinas, a partir dos depoimentos dos alunos e de documentos, mostrou não existir harmonia entre as disciplinas oferecidas quanto a horário, período de oferta e número de créditos, e não haver ainda regularidade de oferta, sugerindo este quadro que não se faz avaliação ou mesmo controle das disciplinas desenvolvidas. Os conteúdos, apesar de diversos, não dão conta das expectativas dos alunos e são desenvolvidos de uma forma que não parece ajudar o aluno a aprender a desenvolver uma reflexão sobre seu tema de pesquisa ou então a repensar a lógica e os valores sobre sua formação anterior na perspectiva da saúde pública. Não demonstra existir coordenação pedagógica dessa atividade, nem clareza de direção do curso.

Buscando então opinião dos professores sobre o programa de disciplinas da FSP encontramos depoimentos que reforçam a fala dos alunos.

Quanto ao quadro existente um professor trouxe a seguinte observação:

(2P) Se tem disciplinas que se superpõem e outras que tem lacunas, quer dizer, temos muito ou poucas disciplinas? Quer dizer, se você olhar as disciplinas, tem muitas, né. Se a pós graduação deve conviver com a diversidade, das ofertas, e não sei o que ... ela ... o maior número de disciplinas ... seria salutar. (...) Mas ao mesmo tempo, se essa diversidade é de tal forma que pulverize e até que deixe lacunas ... etc ... etc ... significa que alguma coisa está apontando, que você poderia preencher uma lacuna ... não necessariamente acrescentando outra disciplina, mas talvez revendo o conteúdo de duas ou três que poderiam ser eventualmente articuladas.

Ao descrever o processo de seleção percebemos o professor "sozinho em seu dilema", ao questionarmos sobre disciplinas encontramos o seguinte depoimento:

(6P) ... eu acho que o grande problema da administração do curso é a questão da excessiva liberdade que nós temos como docentes, porque a pós-graduação é feita ao nosso gosto e da nossa maneira ... porque você como docente propõe as disciplinas ... Se ela estiver minimamente arrumada, coerente, ligada a uma linha de pesquisa, os departamentos encaminham para a CPG ... a CPG ela também se estiver ... se ela for minimamente coerente com a proposta ela aprova e aí você dá, quando você quer, da maneira que você quer, quantos alunos você quer e com a freqüência que você desejar 
(...) nós temos uma liberdade muito grande em relação à pós-graduação. Nós orientamos quem nós queremos, quando queremos e obedecendo 0 mínimo ...

Outro professor completa a questão do "excesso de liberdade" mostrando como a FSP se organiza para trabalhar com a criação e condução de suas disciplinas.

(2P) Mas ao mesmo tempo, então uma das questões é a própria intencionalidade da ... e portanto a partir dessa intencionalidade, que componentes ela deve ter, que estrutura ela deve ter. Então, primeiro as próprias linhas do que se pode e deve oferecer. Na linha de não ser suficientemente estreito para não limitar os campos temáticos, numa saúde pública que está cada vez mais se diversificando, mas também não ser tão atomizada, que você não tenha praticamente uma direcionalidade. Então, essas composições por campos temáticos é uma coisa que deve ser revista. Quer dizer, está sendo revista (...)

Bom ... as eletivas elas tem..., um docente que trabalha na pós graduação, etc, quer dizer, a eletiva é quase que um dever e um direito, né, um direito e um dever ... do professor criar porque aí ele desenvolve a sua linha de interesse, ou seja, ele trabalha com aquilo que é um ponto que ele trabalha como produção de conhecimento disso, do ponto de vista de pesquisa disso, do ponto de vista de capacitação disso, etc. Muito bem, mas a pergunta que se coloca é o seguinte: que equilíbrio se teria nessa liberdade que deve ter, versus uma pós graduação que teria alguma intencionalidade? Ou seja, se você tem alguma intencionalidade, você poderia discutir algumas disciplinas eletivas, que pudessem compor ao longo do tempo um campo temático de uma opção. Sem anular o direito da pessoa colocar, ou seja, concretamente o que eu quero dizer é o seguinte: repito, é apenas um pensamento de tempos acumulados aí ... de reflexões, quer dizer, repito ... Como é hoje temos as obrigatórias, e cada um de nós tem o direito de propor eletivas. Então, o elenco das disciplinas da Faculdade é um elenco de disciplinas absolutamente aleatórias, que surgem em função do interesse, e aqui não tem nenhum caráter pejorativo isso, do interesse sadio, no sentido de contribuição de cada docente. Muito bem. E como se faz então o programa de trabalho que seria a composição temática de um aluno que entrou na área de concentração " $x$ "? Nós temos um elenco de disciplinas, oferecidas de motu próprio, de modo absolutamente livre, e que nós vamos escolher dentre essas

(...) Então, a pergunta concreta é essa: que eu me faço e que eu não estou certo de fazer, etc ... É: isto, ao mesmo tempo que preserva o direito de cada um oferecer a sua disciplina, isto permite que aleatoriamente ... ou seja aleatoriamente a gente realmente compõe um campo temático de pós graduação? Ou a gente usa o que tem, mas essas coisas realmente não são pensadas como um campo temático. Ou seja, será que seria ruim, seria pior ou melhor, por exemplo, se pensar na área temática " $x$ " que seria do curso, e esse curso seria composto por um 
grau de conhecimento de diversas áreas, cujas disciplinas seriam oferecidas pelos professores, mas em função de uma discussão comum de onde se quer chegar naquela área temática. Ou seja, eu posso oferecer uma disciplina por exemplo na minha área de gestão de serviços, de planejamento, etc, mas eu posso oferecer uma disciplina de serviço extremamente livre, para quem quiser, etc ... e eu acho que isso aí deve ser preservado porque é uma coisa que é salutar, tipo assim uma eletiva mesmo, mas talvez eu pudesse oferecer uma disciplina que embora fosse minha, embora eu discutisse qual é a linha temática, qual é o conteúdo dessa disciplina, etc ... eu também discutisse com outros colegas que estivessem envolvidos na mesma área de concentração, o que da área da minha disciplina estou oferecendo que poderia ser retirado ou acrescentado para ... em benefício do conjunto temático da área de concentração. Aí, ou seja, em função do que eu chamei da intencionalidade. Em outras palavras, a gente fazer intencionalidade aleatoriamente e a soma das diversas partes isoladas dão um todo, ou a gente pode pensar no todo que a gente quer chegar e a partir dali, com toda liberdade da pessoa, etc, discutir que pedaço desse todo a gente daria na sua área de especialidade, no seu jeito de propor a disciplina. Sem anular que ele possa ter disciplinas a seu livre critério, porque é um direito que ele tem, e isto estimula a criatividade, crescimento etc. ... etc.

Ao observar o dia a dia da FSP percebe-se que a criação e 0 desenvolvimento dessas disciplinas estão realmente na dependência exclusiva do professor, apesar da exigência de que a proposta de criação da disciplina seja aprovada pelos conselhos departamentais e CPG.

O Seminário promovido pelo Departamento de Prática de Saúde Pública e referido anteriormente, apresentava para discussão do corpo docente a seguinte questão: "com que critérios o departamento pretende trabalhar na reformulação deste quadro de disciplinas de Pós-graduação, envolvendo entre outros os seguintes aspectos: quanto aos pré-requisitos profissionais e disciplinares; permanência, ou não de disciplinas obrigatórias para todos os alunos; redefinição das áreas de concentração; identidade temática e intencionalidade programática das áreas de concentração; extinção, revisão, reformulação e introdução de disciplinas, tendo em vista o novo reordenamento do Departamento e as áreas temáticas".

Estas são questões, considerando o quadro exposto, pertinentes e fundamentais para o processo de revisão do departamento em questão mas pertinentes também para a pós-graduação da FSP, e que ainda não foram discutidas de forma abrangente o suficiente para obtenção de conclusão a esse 
respeito. Parece que "o fio" que pode puxar esta discussão está no que anteriormente apresentamos ao considerar diferentes grupos e expectativas dos alunos e clareza sobre as finalidades da pós-graduação.

Outros processos estão sendo desencadeados na FSP como, por exemplo: "avaliação docente e de disciplinas obrigatórias e eletivas de pósgraduação". Iniciado em 1997 pela CPG, constituiu-se no envio pelo correio, aos alunos, de dois questionário fechados, porém as respostas ainda estavam sendo tabuladas pelos próprios alunos, quando este trabalho estava sendo encerrado, deve trazer também contribuição a este processo de revisão que a FSP vem desenvolvendo.

O Departamento de Saúde Ambiental procedeu a uma revisão de suas disciplinas, em 1997, procurando dar uma determinada seqüência de conteúdo aos alunos da área de concentração Saúde Ambiental a partir das disciplinas obrigatórias. É uma iniciativa que merece ser acompanhada e avaliada.

Apesar de termos dado grande ênfase na organização da grade de disciplinas, não consideramos que a reorganização da mesma seja suficiente para evitar os problemas apresentados. Para nós elas são indicadoras de que o currículo gira em torno do professor, e está sem definição clara do objeto saúde pública ou das finalidades do curso em função das características das atividades de extensão, ensino e pesquisa da FSP. Talvez seja ainda um currículo muito voltado à profissionalização do sanitarista como compreendido no Curso de Especialização em Saúde Pública.

\subsection{RELAÇÃO COM O ORIENTADOR E COM O AMBIENTE}

\section{ESCOLAR}

Um ponto sensível e importante em cursos de pós-graduação está na relação orientador-orientando. Buscamos nessa relação identificar processos que pudessem superar as lacunas do curso apontadas até agora.

Segundo SEVERINO (1993) - "O fundamental é observar que o processo 
de orientação deveria ser um processo que efetivasse uma relação essencialmente educativa. Com efeito, o orientador desempenha o papel de um educador, cuja experiência mais amadurecida interage com a experiência em construção, do orientando. Não se trata de um processo de ensinamento instrucional, de um conjunto de aulas particulares, mas de um diálogo em que as duas partes interagem, respeitando a autonomia e a personalidade de cada uma".

“... Ele é um educador, estabelecendo, portanto, com seu orientando uma relação, com tudo que isto significa, no plano de elaboração científica, entre pesquisadores. A verdadeira relação educativa pressupõe necessariamente um trabalho conjunto em que ambas as partes crescem. Trata-se de uma relação de enriquecimento recíproco. É necessário que ocorra uma interação dialética em que esteja ausente qualquer forma de opressão ou de submissão".

Os alunos mostram nos depoimentos uma relação com o professor em sala de aula que não se aproxima do apresentado por Severino.

Em relação à atividade de orientação na FSP os alunos trouxeram duas situações bem distintas.

Os que estão em dedicação exclusiva para a pós-graduação e diretamente envolvidos em linha de pesquisa ou mesmo em projeto de pesquisas do orientador ou do grupo ao qual pertence o orientador, falam de um bom entrosamento, de liberdade de trabalho, de troca de experiência e crescimento.

(6A) Eu tenho uma disponibilidade quase integral, mas eu não posso ficar direto em São Paulo ... eu venho para São Paulo constantemente para fazer supervisão, tem supervisões telefônicas quilométricas assim ... horas ... quer dizer, uma paciência, uma disponibilidade enorme do orientador... mas eu venho pelo menos uma vez por mês para supervisão, passo dois ou três dias aqui (...)Mas essa linha direta que eu tenho aqui, que qualquer dúvida que eu tenho eu subo no segundo andar ... e mostro ... é fundamental assim ... Eu sei que tenho um nível de autonomia muito grande, a minha forma de agir é muito assim ... chegar com as coisas mais ... não ficar dependendo da benção para cada coisa. Mas nesse momento particularmente estou precisando (...) Eu tenho clareza, assim ... é como se me olhasse no espelho e visse a digital deles (os professores) ... profissionalmente, e isso para mim é muito legal. Se meu orientador está em outro lugar, em outro lugar do mundo e vê um material que pode servir para a minha tese ele chega depois $e-a h \ldots$ 
xeroquei um negócio para você ... -, uma sensação assim de parceria mesmo ... (...) o grande barato do doutorado aqui está sendo assim ... tudo que eu tenho de peculiar ... não está sendo só respeitado, está sendo cultivado, valorizado ... a terra afofada, regada ... isso é uma coisa que está sendo assim ... isso norteia meus passos, diferente do que as pessoas descrevem do mestrado.

Como a própria aluna reconhece, parece que sua experiência está sendo diferente da dos outros alunos. Chamamos à atenção para a sua inserção no curso, ela coordena um projeto de pesquisa, objeto de seu doutorado, que conta com recursos do Ministério da Saúde, e onde seu orientador é consultor. Além de acesso fácil ao orientador ela conta com a possibilidade de utilizar o espaço físico de um núcleo de pesquisa da FSP, acesso fácil a informações e a outros recursos da Faculdade.

A aluna ( 8 A) recém formada, após entrar no mestrado aceitou participar de um projeto de pesquisa grande com recursos financeiros e que envolve grupo de pesquisa externo à Faculdade, mais dois pós-graduandos da FSP, e assessoria de um docente da FSP, devendo ter como produto uma tese de livre docência, do coordenador do projeto, e três dissertações de mestrado. Além disso ela veio com a expectativa de fazer pesquisa, tem dedicação exclusiva à pós-graduação, e tem desenvolvido outras atividades relacionadas à pesquisa juntamente com sua orientadora.

(8 A) ... eu falo que devo estar tomando hora de algum orientando ... e assim, não é tudo só voltado ao meu projeto. Por exemplo, antes de vir para cá, estava fazendo coisas dela ... porque eu tenho essa participação, nos projetos dela, na linha de pesquisa dela ...

$P$ : você chegou a escrever algum artigo com ela já?

R: não, mas a gente está encaminhando ... ela vai publicar um livro, eu vou escrever dois capítulos do livro dela (...) então assim ... é interessante que o nosso vínculo não é só o vínculo do meu projeto ... mas é com a linha de pesquisa dela ... então, tem coisas que eu faço, e que tomam tempo ... que não são coisas do meu projeto ... mas que são coisas que eu acho que também são da pós graduação, que é essa inserção num grupo de pesquisa, da colaboração com o trabalho geral ... então isso eu acho muito positivo ... Está passando um trabalho dela agora na reunião, que não tem nada a ver com a minha ... tese, né .

Nesta situação relatada como positiva cabe perguntar em que medida está sendo respeitada a autonomia do aluno. Ele não tem projeto próprio, assume a execução do projeto de um grupo. Provavelmente esta aluna terminará a pós- 
graduação em espaço curto de tempo, primeiro pela sua expectativa de logo fazer o doutorado para se inserir como docente no mercado de trabalho, e segundo porque já entra em um processo de pesquisa com estrutura e financiamento. Existem portanto aspectos positivos e negativos dessa situação.

Lembramos que a maioria dos alunos da pós-graduação foram identificados por nós como já tendo grande repertório de experiências profissionais, eles podem não chegar com um projeto pronto mas trazem determinadas preocupações que querem transformar em pesquisa.

Segundo SEVERINO (1993) há várias posições assumidas perante o relacionamento orientador/orientando: "alguns entendem que o orientando deve pesquisar sobre o assunto de interesse do orientador e trabalhar sobre um rígido esquema por ele determinado; outros já deixam o orientando totalmente solto, numa situação de total independência, até mesmo perdido".

(2A) Desde o começo ... na verdade a orientação foi minha mesmo ... a concepção do meu projeto foi minha ... Eu tinha claro o que eu queria fazer. Eu tinha, quer dizer, eu tinha essa curiosidade, eu tinha essas questões na minha cabeça, eu queria ver essas coisas que eu estou fazendo ... né. Então, eu, na verdade, eu fiz o meu projeto ... eu fiz o meu projeto.

(7A) Como eu vim ... é uma coisa que eu percebo, como eu vim com um trabalho já meio elaborado na minha idéia, eu tinha uma proposta pronta ... de pesquisa ... e eu vi ... eu percebi que isso não era uma coisa muito legal, você chegar com uma proposta de pesquisa pronta quando essa pesquisa não é ... já uma coisa que é de conhecimento da pessoa que vai te orientar, pelo menos da realidade que eu vivo, né. Eu percebo que às vezes ... e eu vejo também isso conversando com os outros alunos, às vezes alunos de mestrado que não tem sequer a menor idéia do que vá ... do que quer... quer pesquisar qualquer coisa, fazer uma dissertação qualquer, não importa se vai estudar unha encravada, ou se vai estudar coisas altamente sofisticadas ... só quer desenvolver algum trabalho científico. Eu percebo que é mais fácil você ser aceita quando você está completamente limpa de idéias, do que quando você tem um projeto de pesquisa. A menos que esse projeto de pesquisa já esteja atrelado ao interesse da pessoa que vai te orientar. Claro que quando está atrelado é juntar sopa com mel e a coisa avança de uma forma muito legal. Mas a minha ... o meu projeto de pesquisa não é uma pesquisa comum. São poucos os trabalhos que existem nessa área, é pobre a literatura internacional a respeito de estudos do que eu quero estudar. Então, também teria que ser um desafio para quem vai me orientar, também de aprender junto. E vasculhar ... enfim ... E as pessoas ... eu 
também vejo que às vezes os professores estão tão assoberbados dos seus próprios projetos de pesquisa, da sua garantia de permanecer não só na universidade ... eu sei que eles tem tarefas ... eu não sei se são tarefas que a gente poderia dizer ... tem objetivos, metas a alcançar ao longo do ano exigidos pela própria instituição. Fora as palestras, fora as orientações, enfim ... são pessoas que também estão comprometidas com muitas coisas. Fica difícil ... eu tenho essa leitura. É muita coisa. Fora a questão da empatia que às vezes você não bate com a pessoa, com o jeito que a pessoa é, age ... e no meu caso eu acho que isso pinta também

Esta aluna (7A) está ligada a serviço, apesar de possuir dedicação exclusiva à pós-graduação, o tema de pesquisa nasceu de seu local de origem e foi, no momento da seleção, considerado próximo à área de sua orientadora.

O depoimento de um professor completa a observação dessa aluna.

(8P) ... as duas alunas que estão comigo são vinculadas a propostas próximas, a área que trabalho. Existe uma identidade do objeto de estudo, da área de interesse. Agora o outro, ninguém estava querendo ele como orientando, por conta do tema dele que era homeopatia ... ele foi um aluno meu de especialização. E veio conversar comigo ... que tinha essa proposta ... mas era uma coisa que para mim era um certo sacrifício, tinha que ler coisas de homeopatia que não tinha muito interesse realmente ... Não era meu foco de interesse ... uma coisa ... e aí ele acabou desistindo P: ele foi para outro orientador?

R: não, não, desistiu do curso de pós graduação. Aquelas coisas, eu não deveria tê-lo aceito como orientando, mas tínhamos uma empatia no curso, mas isso não é suficiente para segurar uma relação orientador - orientando

Retornamos agora ao processo seletivo, onde pelos depoimentos percebemos também existir essa preocupação de não dispensar 0 aluno. Dependendo dos critérios departamentais, o aluno se encaixa nas prioridades, ou seja, é docente ou então foi bem classificado nas provas mas seu tema de interesse não está perfeitamente encaixado na área de interesse do orientador. Talvez por isto discuta-se na FSP se não seria muito precoce definir o orientador na primeira fase do curso.

Os alunos que sentem limitações quanto à orientação se referem a dificuldades para encontrar o orientador, ele está muito ocupado e não tem tempo para recebê-lo ou para ler o material que é entregue. 
(10A) Agora, eu também vi que tem um monte de gente que tem problema de orientação lá - ah ... eu não consigo achar o orientador ... -, quer dizer, eu não sou a única que o orientador não recebe ... que acontece isso ... que enrola, que empaca ... Então, eu não sei muito como é que você melhora isso ... (...) eu tinha o primeiro semestre para entregar, né, as coisas que eu escrevia, mandava, ela demorava ... ficou assim ... dois meses e ela não leu ... Gente, aquilo dá um desespero, quando o orientador não lê você fica parado, né ... vai te comendo tempo.

(10A) ..., eu ligo ... eu pego no pé, eu vou atrás... Aí ligava para ela, falava e ela falava assim - ah ... mas ... -, ela sempre tinha um problema não, em julho vou te receber ... -, e eu tenho uma outra amiga que é orientanda dela que também é de Campinas e está com o mesmo problema. Tanto é que ela tinha que entregar no fim de junho, o projeto para qualificar e não entregou, teve que prorrogar o prazo. Então, nesse meio tempo ela viajou ... aí ela marcou um dia comigo em julho ... - não, em julho vou me dedicar a vocês duas ... -, ela falou ... aí ela teve problemas de família. Problemas de família você entende, mas ... eu acho que ela pega um monte de coisas para fazer, no fundo é isso ... sabe quando assume um monte de compromissos e aí ela tem outros alunos, ela está dando aula fora ... não sei em que curso que estava tendo, que era fora ... Era da Faculdade, mas parece que era fora ... Então, ela tem um monte de atividades e aí você vai ficando. Ai a última vez que ela ligou e desmarcou comigo, a gente ligava, marcava, aí desmarcava ... aí eu entrei em pânico, porque eu pensei - além de tudo, estou grávida ... -, aí que estou perdida mesmo. Porque ainda foi assim, eu tirei férias em agosto ... porque eu tinha que tirar que já vai vencer outra ... então antes do bebê nascer, férias ... Aí eu tiro e o que vou fazer? A gente olha tudo, fico em casa, monto todas as tabelas e ando com a coisa, para ficar tranqüila depois ... aí ela me recebeu no meio das minhas férias ... quer dizer, eu perdi um tempão. Aí ela falava assim - vai lendo ... vai lendo ... e vai melhorando a introdução ...

Outro fator que pode dificultar a aproximação entre aluno e professor são os afastamentos longos de professores para desenvolver atividade em outras instituições.

(5A) ... cheguei a montar o projeto ... mas aí eu tenho uma dificuldade. Eu vou contar para você por que ... porque assim ... o meu orientador ... virou uma alta figura do Ministério ... né ... e eu não consegui mais ter contato com ele ... estou com uma dificuldade. Tanto é que estou pedindo para trancar minha matrícula no próximo semestre, para eu dar uma respirada e montar o meu projeto ... Porque eu comecei numa linha, mas assim ... não tive mais nem oportunidade de estar conversando com ele ... é uma fase muito difícil. Então, eu fiquei dividida entre três coisas ... né ... Entre o meu trabalho, que eu estava afastada, entre tentar garantir o 
diabo do crédito que eu tinha que ter e o orientador que eu não conseguia fazer contato. Então, eu priorizei o seguinte: vou terminar os créditos, vou continuar meu trabalho que não tenho outra alternativa ... vou terminar os créditos e depois montar a tese. E aí seria esse semestre agora ... que eu estou terminando. Só que nesse semestre ... ficou mais difícil falar com o orientador ...

Sendo esse chamado para o Ministério, considerado importante para a FSP, como já comentamos, mesmo assim não se prevê nenhum tipo de acompanhamento, ficando a solução para o orientador e para o orientando.

O desabafo de uma aluna resume situação de não se sentir recebida para orientação, passando a imagem que o professor está à disposição dos alunos só nas horas vagas.

(7A) E eu tinha uma ilusão de que o orientador fosse um orientador ... não sei se é a acepção da palavra, mas uma pessoa que de fato te orientasse, no sentido de te ajudar a enxergar, a ver, a pensar, o que é melhor dentro da sua linha de pesquisa você estar buscando. Então, algumas dicas eu tive, muito boas por parte da minha orientadora, algumas disciplinas, inclusive uma disciplina fora na Medicina Preventiva, que eu gostei demais, mas ... Agora, o resto meio que foi por minha conta e eu achava que o acesso entre o orientador e o orientando fosse também uma linha mais ... mais direta talvez ... sem ... às vezes sem tantas formalidades, de você ter que marcar hora ... enfim ... Eu tinha uma idéia errada, ingênua ... talvez como uma escola de primeiro grau onde o professor está sempre a sua disposição ou à princípio estaria sempre a sua disposição para pegar pela mão e dizer - aqui, lá ou acolá ... -, eu fui descobrindo que aqui não é bem assim ... a trajetória do aluno de pós graduação.

(...) eu sinto que com outros alunos eu converso ... eu sou uma pessoa que converso demais com as outras pessoas ... e eu sinto que com alguns a realidade é muito parecida com a minha. E com outros é completamente diferente. É o sonho que eu tenho ... da porta aberta ... da comunicação tranqüila, da atenção ... de uma atenção boa com relação ao aluno ... de laço, de empatia com o orientando. E com outros não é. Ainda ontem estava conversando com um aluno que é ... da Universidade de Brasília e ele estava dizendo que lá na Universidade tem uma sala para os mestrandos em cada departamento. E que essa sala tem ligação direta com a sala dos professores daquele departamento. Então, eles tem um fluxo muito direto, e que aqui ele está estranhando muito porque ele tem que marcar hora, é difícil marcar hora ... a disponibilidade às vezes do orientador não é muito grande ... ele não consegue se abrir nem para trocar dúvidas ... Ele acha ... ele dizia que ele tem dúvidas que ele não tem nem coragem de perguntar ... é um homem grandão ... é um homem ... adulto ... de uns ... quase 40 anos, um profissional e ele diz que tem coisas que ele acha que pode ser banal, ... 
que ele não tem coragem nem de expor porque não sente espaço para isso e tal.

Então, eu percebo ... esse falou isso ... Tinha uma outra moça dizendo ... é assim também para mim, parece que o orientador está sempre correndo contra o relógio ... a gente não sente às vezes a calma necessária para o orientador te ouvir ... ouvir com tempo, até para suas besteiras, para suas besteiras científicas ... de pesquisa ... as dúvidas que passam pela cabeça da gente. $E$ eu ... eu tive poucos contatos com a minha orientadora. Com relação a agendamento de horários, alguns horários que eu agendei acabou acontecendo de eu não poder estar. Isso pegou muito mal ... aconteceu de eu agendar horário e me atrasar meia hora ... pegou mais mal ainda ... E ... apesar de ter uma justificativa de cunho pessoal ... não foi má vontade da minha parte, desleixo, mas isso pega muito mal ... uma coisa que ... não foi dando certo ... E eu estou, hoje em dia, há um ano e meio no mestrado, completando o meu segundo ano de mestrado, estou terminando os meus créditos, não terminei os meus créditos ainda em função dessa falta de ... dessa dificuldade de relacionamento com a minha orientadora, que só em abril desse ano eu tentei solucionar e ... parti para uma resolução. Tentar conversar com ela, e estou trocando de orientador desde então. Então, eu estou assim, numa situação que eu tenho uma orientadora oficial, tenho um orientador possível, que é uma pessoa extremamente ocupada e eu estou tentando na verdade ver se eu encontro outro orientador ... que tenha mais disponibilidade, porque eu não me sinto uma pessoa tão autônoma para desenvolver uma pesquisa, um projeto, tão independente, enfim ... autônoma mesmo, de fazer, fazer ... fazer ... e levar quase tudo pronto. Eu ainda estou numa ... ainda eu não consegui perder a minha ilusão de tentar encontrar alguém que me oriente, no sentido de me acompanhar mais de perto nas minhas dúvidas, de me ajudar a aprender a desenvolver projeto de pesquisa.

Uma professora, comentando o processo de orientação, indica a dificuldade de agrupar os alunos para realizar a orientação, devido à estrutura do curso e à procedência do aluno. Esta talvez fosse uma possibilidade de melhorar a qualidade da orientação, apesar de que o processo de orientação em si seja mesmo individual. Consideramos este aspecto trazido semelhante ao desejo do aluno de existir espaço para discussão de temas de pesquisa com grupos de alunos e professores.

(6P) eu acho que a nossa orientação aqui na Faculdade, ela é uma orientação difícil e individual ... a nossa experiência em Caxias com as orientações conjuntas são muito ricas. Você não consegue aqui orientar ... reunir os seus alunos porque cada um está numa fase diferente, ou então num estágio, ou moram em lugares diferentes, né. Então uma boa parte do trabalho deles depende do local de origem, né, 
então ou você tem alunos que estão cursando as disciplinas básicas, então eles nunca aparecem.

Os professores por sua vez "se queixam" que os alunos "somem". Isto parece acontecer por problemas de ordem pessoal, ou por demandas profissionais para aqueles que vem de serviços e não são liberados para fazer a pós-graduação. Além disso mudanças na estrutura dos serviços exigem dele revisão de seus projetos ou mesmo maior afastamento da pós-graduação.

VIEIRA (1998) em seu livro: "Como escrever uma tese" faz recomendações ou "dá dicas" para quem está escrevendo uma tese, que deixam claros que problemas com a orientação são comuns. Por exemplo, a autora diz:

"Leia o que escreveu. E reescreva. Depois, peça para alguém ler - e comentar. Se seu orientador é do tipo "muito ocupado" (que os há os há), peça para um colega ler".

"Boa parte dos alunos queixa-se da falta de orientação. Tais queixas nem sempre procedem, mas, às vezes, elas são mais do que justas. O aluno procura, então, a ajuda de pesquisadores na instituição de origem, de colegas e de outros professores, que não o orientador".

Consideramos que a procura de outras pessoas, outros especialistas traz muita contribuição ao trabalho e é recomendável, porém em alguns depoimentos ela aparece como um mecanismo de sobrevivência utilizado para sanar lacunas deixadas pelo orientador.

Existe para os alunos da FSP o que poderiamos chamar de "orientação paralela informal" muitas vezes os próprios docentes da FSP são procurados para suprir ou complementar a "orientação oficial"; envolve ainda amigos e colegas de trabalho.

(10A) Tem uns professores lá que, por exemplo, AC., que ela me orientava sem ser orientanda dela ... eu fiz cursos que eu ia perguntar, pedi bibliografia para ela ... ela me arranjou bibliografia, ela me dá as coisas ... ela lia as coisas comigo ... e eu não sou orientanda dela. Vamos dizer assim, o que ela está lucrando em dar apoio para alguém, vamos 
dizer ... sendo fria. Mas ela dava atenção. A M.L. também, eu ia conversar com ela ... A S. de bioestatística ...

$(3 A)$...com um amigo da Colômbia, que está em Johns Hopkins, então eu discuto com ele muitas coisas, que eu não tenho espaço para discutir nas salas ... com o professor. Eu falo - tenho tal dúvida ... o que você acha? -, aí ele responde ... Em relação à tese - o que você acha ... -, e como ele tem muita experiência e está muito informado, e eu tenho contato com ele ... E basicamente também eu tenho uma amiga em Chile, que é uma chilena ...

Os alunos procedentes de instituições que possuem estrutura e tecnologia que favoreça a pesquisa, contam com a "orientação informal" de colegas de trabalho que também fazem pós-graduação.

(9A) ... eu discuto com os colegas que fazem mestrado (do local de trabalho) ... Tem o Departamento de Pesquisas, boa parte dos funcionários fazem mestrado, doutorado ... então eu discuto assim ... detalhes de montagem e tal ... mas a escolha do tema não ...

Os exames gerais de qualificação e a pré-banca (julgamento da minuta de tese) são dois momentos bastante positivos do curso. A qualificação é em primeiro lugar um espaço de socialização dos projetos de pesquisa e ambas trazem contribuições e visões novas ao estudo.

(2P) ... tem hora que a gente tem que ir para a qualificação para ouvir sugestões e críticas de outras pessoas. Por que esgota os argumentos e a conversa empaca...

Mas parecem estar também sendo aproveitadas para suprir parte do trabalho de orientação, ou resolver divergências conceituais e metodológicas entre orientando e orientador, e o clima de tensão caso tenha se estabelecido no processo.

(10A) Como vou defender aquilo que eu não acredito? Então, ela falou algumas coisas para eu alterar no projeto, que até não concordava. Ela falou - não, não, tem que colocar porque está muito assim, assado -, quando chegou na defesa, na hora da qualificação eu ouvi uma crítica horrível, que eu concordava com a crítica e tive que responder ... aí tive que achar... e aí eu olhava para ela e - olha, pergunta para ela, porque eu também concordo com isso, não queria escrever isso ... -, e ela falou não, escreve assim ... porque (...)- Era exatamente isso que eu queria e a banca falou - faça isso -, eu adorei, amei ... amei .... 


\section{Convivendo com a escola}

Consideramos importante conforme SAVIANI (1998) apresenta ao conceituar currículo, que o espaço da escola seja "adequado e atraente", ou seja, acolhedor para o ensino, um espaço que tem por objetivo formar pessoas. Quando os alunos comentam sobre o espaço escolar além do já discutido sobre a orientação e a sala de aula, fazem observações relativas aos recursos físicos disponíveis e à comunicação institucional.

A convivência na FSP, com o espaço de aluno não é uma preocupação levantada pelos entrevistados que têm no seu espaço de trabalho, ambiente para desenvolver sua pós-graduação, por exemplo, o SEADE e a CETESB, possuem boa biblioteca, grupo de pesquisadores, microcomputador, Internet e secretária. São alunos que têm muitos anos de formado e estão estabelecidos em seu local de trabalho, procuram a FSP com objetivos muito específicos, não consideram depender dela. Ficam muito pouco tempo na escola, praticamente não dependem dos recursos de infraestrutura da FSP.

Podemos imaginar que, dado o cargo que possuem, estabelecem outras relações profissionais com os professores caracterizada mais como a de colegas do que professor/aluno. Seria interessante aprofundar a compreensão desse tipo de situação, acompanhar as dificuldades ou facilidades que poderão surgir para a conclusão da pós-graduação.

(9A) ...eu quase não ficava lá, só ia para as aulas (...) a biblioteca daqui (CETESB) é uma das melhores da área.

Outros alunos falam de um sentimento de não pertencimento à Faculdade. Atribuem isto à cultura institucional que segundo eles é caracterizada pelo "não acolhimento". Os alunos sentem-se "soltos" e "dispersos".

(2A) ... uma sensação que eu senti algumas vezes, de uma desqualificação desse ator que existe aqui dentro, aluno, né, isso foi em alguns momentos. Assim ... o aluno com um algo um personagem menor ... como uma entidade, né, aqui desse espaço, menor. E isso é uma sensação muito desconfortável. Até que uma vez eu senti mesmo isso concretamente. E eu ... eu tive ... digamos assim ... até um certo enfrentamento, que eu falei assim - que não me tratasse assim porque eu 
sou técnica ... eu sou uma professora ... eu sou aluna da pós graduação, e na minha universidade não se trata assim um aluno de pós graduação -, aliás, nem o aluno da graduação, eu não trato assim nem o aluno da graduação ... E ... então ... era uma sensação assim ... que depois eu fui traduzindo assim que eu sentia uma falta de acolhimento ao aluno, no caso da pós graduação, a sensação que eu posso falar é em relação à pós graduação ... Então, uma falta de acolhimento a esse aluno da pós graduação. $P$ : por parte dos professores ou da própria escola?... eu acho que da escola, entendeu, porque assim ... a experiência que eu tive com alguns professores não foi essa ... mas algo da cultura institucional assim ... então essa falta ... é uma sensação que depois eu fui traduzindo ... né ... essa falta de acolhimento

(2A) ... Mas eu sinto um certo ... um certo isolamento nessa Faculdade ... né. Assim, ... tem muitas vezes os espaços institucionais, você tem uma conferência, uma palestra ou algum evento que congrega pessoas, mas eu sinto uma coisa muito dispersa nessa faculdade, né, entre alunos e professores ... entre alunos. Recentemente até os alunos da pós começaram a se organizar, né, mas eu já estou ... digamos assim, que eu já estou na reta final ... Então, eu sinto muito ... muito ... uma falta de uma coisa que congregue mais(...) Eu não sei se é falta de um espaço de discussão dos projetos de pesquisa ... das teses ... eu ... eu não sei ... Talvez eu esteja também até influenciada nessa minha opinião pela própria experiência que a gente vive lá no Instituto, que tem uma seção chamada pesquisa orientada. Então, nessa seção de pesquisa orientada, todos os projetos são apresentados publicamente, né, então cada discussão de um projeto de mestrado, de doutorado, é aberto ... então todo mundo vai ... aí vão convidados, vão as pessoas que ... quem quiser convidar, convida ... então tem uma ... acho que é um momento que aproxima mais as pessoas que estão envolvidas com a pós graduação, naquele ambiente. A gente sabe o que o outro está fazendo ... o que o outro está pensando em fazer ... né ... Então, eu acho que isso cria uma aproximação maior e eu sinto aqui uma distância ... entendeu? uma coisa muito dispersa e uma distância muito grande entre professores e alunos ... entre alunos e alunos, né. Eu sinto essa coisa. E é uma ... eu sinto isso ... assim ... razoavelmente forte aqui, entendeu, é uma coisa que eu sinto, uma característica dessa faculdade.

O relato da aluna estrangeira exemplifica uma situação vivenciada provavelmente também pelos alunos brasileiros que não são de São Paulo, e chegam em uma cidade grande, não conhecida e não encontram suporte na FSP.

(3 A) Então, foi muito difícil ... E conseguir moradia para estrangeiro é uma coisa muito dura ... muito dura ... As informações sobre a polícia, sobre todos os papeis que você tem que ter ... se eu não tivesse essa amiga que foi minha ponte, eu teria mais trabalho do que eu passei ... porque eu não sabia nada ... porque a embaixada lá não oferece nada ... absolutamente nada ... E quando você chega aqui ninguém te 
recebe, você não conhece nem o diretor ... Você chega como ... não sei ... chega ... e é como uma formiguinha e você se sente tão sozinha ... tão desamparada ... Com o diretor, que eu mandei uma carta para ele, não conheço ele ... como se chama, quais são os departamentos ... o que faz cada um ... como é o processo de orientação ... e eu não tive nada de informações. As únicas que eu tive foi da minha amiga ... e que era limitada também, porque coitada, ela também passou pelas mesmas coisas, né. Então, aí ... a gente vai andando, mas foi duro mesmo. A relação com as pessoas é muito boa aqui no Brasil ... em geral ... esse jeito latino-americano ... isso ajuda muito ... Eu tive sorte, conheci pessoas muito legais ... foi muito bom no início, tive muito apoio nesse sentido, né ... mas a nível institucional ... você chega aqui e da instituição não há uma interface entre o estrangeiro e a instituição, não existe ... Nem na embaixada e nem quando você chega aqui ... então você se sente muito isolada ...

(...) eu cheguei direto na faculdade ... E quando cheguei do meu país, eu já deixei mais ou menos o flat arrumado, minha amiga arrumou, quando cheguei fui para o flat e já tinha aula no primeiro dia ... Quando eu cheguei ... meu Deus de céu ... tudo novo para mim ... sem nenhuma informação para mim, minha amiga estava comigo, agora se ela não estivesse a gente sofre mais ... foi duro mesmo, foi duro. Por que? Porque a gente não tem informação, não sabe o que tem que fazer ... não conhece a cidade. Por exemplo, para mim que venho de uma cidade pequena, são 8 milhões ... eu não conhecia a cidade, o metrô ... como sair, como procurar informação, onde está a informação ... Esse tipo de coisa não existe dentro da faculdade para os estrangeiros ... a faculdade está aberta para receber estrangeiros mas não tem uma infraestrutura mínima ... E agora eu sou representante dos estrangeiros e estou fazendo justamente isso ... estou preparando agora um home-page para que o aluno estrangeiro que chega. Agora, não terminei ainda, acho que no ano que vem que vou terminar ... porque com tantas disciplinas não dá ... Estou aprendendo a fazer home-page e fazendo, né ... mas eu tenho que falar com a USP para ver se ela permite entrar... Então, vou ligar para o CCE lá ... vou falar com $D$. aqui ... perguntar como que é o processo. Mas muita gente não conhece a Internet ...

(...) estou pensando ... o mural ... já falei com a pessoa que é encarregada dos alunos lá na pós ... e ela falou que assim ... um mural especial assim ... não pode, está proibido ... Porque aí no mural que estão todas as notas ... mas aí não dá para ler ... a gente chega e não sabe nada ... Justamente quem chega, que é estrangeiro, que precisa de uma coisa assim ... mais dirigida assim - aluno estrangeiro -, tudo junto, não dá ... tem muita coisa ...

$P:$ e você não conhece alunos estrangeiros de outras unidades da USP. $R$ : ... da USP não, porque é outra coisa. A gente está muito isolado da USP. Eu conheci a USP faz pouco tempo. Então, essa é outra coisa que o aluno tem que conhecer - você tem uma universidade central ... tem direito a tais coisas ... tem H.U ...-, essas coisas que a gente não sabe ...

A ausência de espaço para os alunos também contribui para a dificuldade 
de inserção dele na instituição. O espaço para estudo, a possibilidade de encontrar o orientador ou outros professores em situação do dia a dia poderia ajudar o contato do aluno com a instituição e favorecer seu desenvolvimento na pós-graduação.

(8A) imagina isso ... você é pós graduanda do departamento, e você tem que se apresentar para a secretária, ficar na salinha de espera esperando seu orientador para falar com ele ... não ter esse trânsito dentro do departamento. $E$ isso existe aqui na Faculdade ... isso é o que mais tem aqui ... o pós graduando não tem nem a liberdade de transitar dentro do departamento. É o corredor, o pátio, a sala de aula dos pós graduandos. O departamento é do docente, então você não entra ali. Eu acho que até consegui passar, mas consegui por que? Por estar aqui ... das 8 às 18 horas ... na época de cumprir créditos, por ter sido representante discente ... pela minha orientadora permitir um pouco isso, né. Então ... acaba que ... de ter relações pessoais com os docentes, de extrapolar a relação sala de aula ...

(8A) Na UNICAMP ... eu ia ter uma sala para mim, uma microsala, né, mas uma sala para mim, né, que eu ia poder o que? Quando você pensa em dedicação exclusiva, na pós graduação... tem que ter um mínimo de estrutura para isso. Eu cheguei aqui, e não tinha lugar para eu sentar ... não tinha nem essa sala aqui, né. Então, isso favorece o que? $A$ dispersão, né, então o departamento não absorve o pós graduando, não tem estrutura para absorver pós graduando. Então, o docente tem a sala dele lá, e o pós graduando ... vai para a sala de aula, faz créditos ... vai para o restaurante, passa pela escada ... a lanchonete ... porque não tem nem onde ficar, não tem uma sala de estudo ... não tem um local onde ele possa estar trabalhando, né. Então, eu acho que isso falta. Por que? Porque é a estrutura .?. que se tem na Faculdade. Cem por ano ... sabe ... ingressos ... Eu acho que tem que ser repensado isso ... essa questão. (...). Quem está estrito senso, precisa ter espaço físico, precisa ter cadeira, precisa ter mesa, precisa ter uma sala própria ... Agora, quem vem aqui assistir aula, aprimoramento, conhecimento, não precisa ter essa estrutura toda, né. Então, a Faculdade ... agora a diferença com outras unidades ... Com todos meus colegas representantes discentes das outras áreas, eu tenho o telefone da unidade onde eu posso falar com eles...

Consideramos que o aluno que a escola estava acostumada a receber era o que estava inserido no serviço e não ficava na FSP. A Faculdade agora tem alunos que podem permanecer mas não propicia os espaços para que isso possa ocorrer.

A questão da comunicação ou divulgação de informações na Faculdade parece ser um problema que não contribui para o entrosamento dos alunos na 
instituição.

(7A) Eu sou uma pessoa curiosa, pergunto, gosto de conversar, saber o que a pessoa faz, que trabalho ela está desenvolvendo, então eu tinha uma idéia pálida, pelo menos do departamento que eu tinha maior interesse, do que buscar, né. Então, foi assim ... foi mais ou menos assim que eu montei a minha grade curricular. Mas eu senti muita falta, desde que eu entrei como aluna de mestrado de conhecer melhor qual era a dinâmica da faculdade, o que o serviço ... o que a faculdade oferece para o aluno de pós graduação, em todos os aspectos. E vice-versa, como é que deveria ser ... como que é a relação do orientador com o orientando.

(7A) sinto muita falta daquele mural que saiu dali do corredor, em frente à Paula Souza, onde ficavam afixadas todas as defesas ... porque ali dentro do setor de alunos, eu tenho olhado e não tenho encontrado. (...) eu perdi a referência ... e eu tenho interesse sim, de acompanhar, de ver as defesas de tese, de saber ... mesmo as qualificações. Foi uma pena que tenham tirado de lá, não puseram nada ... não sei ... dentro dessa proposta "clean", por que não deixar um mural, né ... Por que não colocar aquele mural lá?, é passagem das pessoas, é caminho (...) a Faculdade não é facilitadora .... Para o aluno não, eu acho, ela não divulga ... para você conhecer ... é de boca em boca, é uma coisa tão antiga isso ... não é?, a transmissão do conhecimento, do saber, de boca em boca ... é de Platão, de Aristóteles, antes deles até ... né (...) então aqui ... tem ... são incoerências, porque tem coisas de ponta, mas você vai lá no âmago da história e você ... você está atrelada e está sujeita à comunicação verbal das pessoas. Se você é uma pessoa que se relaciona com facilidade com os outros, e vai enchendo o saco e perguntando e é curiosa, você vai montando um quebra cabeças na sua cabeça, do todo ... mas ... o todo ele não é ... não é explícito. Quando a Irene falou que vai fazer um manualzinho para o recém ingresso na pós graduação, eu falei - ótimo, estava mais do que na hora ... -, os próprios ... o próprio corpo discente não se reúne praticamente ... então as informações não correm, as pessoas também seguram. Os alunos entre si muitas vezes seguram ... competem ... de não passar o ouro, a informação que é ouro, aqui a informação tem peso de ouro ... vale ouro ... então não passa.

(...) assim ... o que um aluno vai precisar no seu dia a dia ... tal disciplina é boa, tal é ruim ... essa corre ... Se você vai perguntando, mas se você é uma pessoa mais circunspecta ... você dança (...) eu sou perguntadora ... e mesmo assim você sente que tem informação que não chega (...) Eu falo - puxa, marquei de novo ... -, tinha o congresso e eu estava aqui ... marquei de novo -... é, a informação de que alunos de pós graduação tem direito a pedir subsídios para apresentar trabalhos em congressos (...) então, mais um dado que eu juntei, eu e a outra colega ... a respeito dessas possibilidades. - olha, não sei ... tem uma aluna que foi para Dinamarca apresentar um trabalho e conseguiu tudo pago, não sei o que (...) algumas informações nem os professores tem ... também vai nesse quebra cabeça ... 
Existem recursos importantes para o desenvolvimento da pós-graduação, mas nem todos eles estão bem divulgados entre os alunos. Por exemplo a sala próaluno, que disponibiliza microcomputadores não é muito conhecida “... fiquei sabendo por um aluno desse recurso" ou então outro fato como conhecer a possibilidade de obter subsídios para apresentar trabalho em congressos.

A Biblioteca é considerada um recurso rico à disposição dos alunos. Com as novas instalações a única crítica dos alunos à Biblioteca recai sobre o horário de atendimento - fechamento às 19 horas. Muito cedo para uma escola pública que está localizada na região central da cidade e que tem a maioria dos alunos trabalhando além de estudando.

(2A) na verdade, a minha experiência é boa, a minha experiência de doutorado, de estar aqui em São Paulo ... com os recursos que a cidade oferece ... muito maiores ... incomensuravelmente maiores do que os recursos da Bahia, do nordeste, que a gente sabe disso em todos os sentidos ... né ... Essa biblioteca fantástica que tem aqui ... né ... Era super limitada em termos de espaço, mas em termos de acervo ... né ... a coisa da informática ... dos recursos da universidade como um todo ... Você sair procurando um livro em qualquer lugar e ver onde está através do computador ... isso ajuda muito, né ... isso é muito bom ... muito bom ... isso me ajudou muito ... estar assim, precisando de um livro ... e não ter o livro ... não existir mais em livraria ... e você achar numa dada biblioteca ... né ... quer dizer, ter a BIREME, esqueci de falar que eu usei a BIREME também ... então aqui, à mão, rapidinho, não precisa mandar pelo correio ... e ... e assim né... E ter bastantes outros equipamentos que facilitam, como xerox ... e ter xerox na cidade mais barato ... ter xerox aqui, ter xerox para o próprio aluno manusear, quer dizer, é uma experiência boa. A experiência da Faculdade falta ... essa coisa mais integrativa ...

Durante as entrevistas, ao serem questionados sobre seu entrosamento com grupos de alunos, eles não falam dos colegas como parceiros importantes. $\mathrm{O}$ contato maior entre grupos de alunos ocorre nas disciplinas obrigatórias, mas depois eles se dispersam. Não se referem à sua turma. Quando isto é presente, é um relato que envolve o grupo de estrangeiros.

Observamos que os espaços de representação discente nos órgãos colegiados da FSP não são disputados e nem preenchidos com facilidade. A mobilização que os alunos comentam ter para o trabalho na saúde pública, parece 
não se repetir quando eles assumem o papel de aluno. Talvez o fato da maioria dos alunos não se dedicarem exclusivamente ao curso leve a essa situação. Acrescentamos 0 apontado no início deste item, os alunos com experiência em saúde pública e que já convivem com a FSP antes de serem alunos, vêm na pósgraduação um espaço de troca, ao mesmo tempo para o professor esse aluno também pode parecer mais um colega do que um aluno.

Os alunos parecem passivos diante de todas as críticas trazidas por eles neste estudo. As queixas apresentadas nas estruturas deram a impressão de estarem aproveitando esse momento para falar, por isso a pesquisadora se sentiu porta voz dos alunos. Provavelmente, pelo contexto apresentado, os espaços para interlocução sejam pequenos para os alunos.

Nos últimos três anos começou a existir um movimento dos alunos no sentido de se reunirem para discutir questões da pós-graduação. Iniciou com articulação maior entre os representantes discentes dos diferentes colegiados da FSP e também do representante da Faculdade no Conselho de Pós-graduação da USP. Eles têm participado das atividades promovidas pela CPG - dois seminários para discutir a pós-graduação na FSP, questionário de avaliação de disciplinas e do corpo docente. Promoveram reuniões no horário do almoço, e uma movimentação que não era comum na Faculdade. Talvez a mudança do perfil do aluno tenha favorecido esses fatos.

Com o apoio da diretoria, em 1997 os alunos iniciaram a publicação de um boletim informativo - "Thésis". O boletim tem sido espaço para divulgar a participação dos alunos em comissões e grupos de trabalho da FSP, e em dezembro de 1997, trouxe um "Pequeno dicionário do pós-graduando", feito com a finalidade de ajudar principalmente o aluno novo a se situar na pós-graduação da FSP.

Outras novidade desse período foram assim anunciadas pelo Boletim: "Parece um sonho, mas é verdade! Até que enfim, os pós-graduandos tem sala própria (...) Queremos que este seja um espaço de vivência (convivência) dos PG. Um local para a gente se reunir, conversar, festejar, estudar, não fazer nada, etc e tal. Se você tem uma certa dificuldade para se encontrar aqui na FSP, agora existe uma nova possibilidade de 
comunicação. Há um quadro de recados fixado na nossa sala, através dele você poderá deixar recados para colegas e também para os RD's".

"A sala de microcomputadores da Pós-graduação recebeu algumas melhorias (...). Pena que a sala continua não funcionando no período noturno, que é um horário em que os alunos que trabalham o dia todo poderiam utilizá-la". 40

40 Thésis, número 3, ano1, agosto/setembro, 1997. 


\section{NO COTIDIANO DA PÓS-GRADUAÇÃO UM “SALVE-SE QUEM PUDER”}

Consideramos que o professor é o principal formulador e executor da política educacional de uma instituição de ensino. Segundo SAVIANI (1998) o currículo não terá eficácia se o professor não se apropriar da proposta "como seu protagonista mais importante". A partir dessa consideração procuramos investigar como o professor trabalha na e com a pós-graduação da FSP.

O trabalho do professor na Faculdade, não só na pós-graduação foi percebido por alguns alunos entrevistados como fragmentado, como se não houvesse uma direção, um projeto comum.

(5 A) tem valores isolados, individuais ... você não sente um espírito de corpo ... Eu não estou conseguindo me expressar bem, mas assim ... eu não sinto as pessoas trabalhando pela Faculdade ... sabe ... em favor de ... na direção de crescer a Faculdade ... uma sensação que elas estão trabalhando para elas próprias .... isoladas, num processo de competição muito grande ... umas contra as outras ... Não tem um projeto que junte as pessoas e que valorize a Faculdade. Não tem ... que eu acho uma coisa meio maluca mesmo, porque assim ... se eu tenho um projeto, mínimo coletivo ... que vai valorizar e dar credibilidade para a Faculdade ... isso reverte também para mim individualmente, porque eu estou ligada numa instituição altamente credibilizada, que me dá condições de fazer meu trabalho individual ... minha consultoria ... se eu quiser, porque a gente sabe que o salário de professor é baixo, que é complicado, mas te dá também suporte para isso ... Eu fico pensando, por que será que as pessoas não fazem isso? Será que a questão da competição, individualismo, é tão mais forte do que essa ... né ... quer dizer, chega a ser tão grande que deixa as pessoas aparentemente cegas, porque isso não é uma cegueira ... não as pessoas do nível que tem lá ... nessa fase da vida e com o conhecimento ... desenvolvimento intelectual ... você não pode dizer assim - será que elas não estão vendo? ... que bobagem ... - não é isso ... tem alguma outra coisa ... que isso está sendo muito mais forte, a desagregação e o individualismo ... a competição entre as pessoas ... é muito mais forte, né, do que a possibilidade de uni-las num projeto, de valorização da instituição. Pronto, é essa a minha leitura da Faculdade de Saúde Pública ... é uma leitura amarga, dura ... triste ... não gosto de fazer ...

(...) acho que aliado a isso, também tem uma crise externa à Faculdade, que também a gente não pode fechar o olho, né. Acho que a crise externa à faculdade é exatamente a crise do sistema de saúde ... do modelo que está se propondo e que não se viabilizou, que é externa à Faculdade, que acho que termina contribuindo para esse "salve-se quem puder" lá 
dentro ... - Eu não sei também por que rumo vai a saúde pública, então ... deixa cuidar da minha vida e esquecer o projeto maior -. Não sei ... eu acho assim ... essa coisa externa é importante. Agora também ela é importante mas não paralisa outros serviços, né ... então como é isso? Acho que a gente está vivendo um momento de crise muito grande ... na saúde pública, na formação dos profissionais ... os sanitaristas de uma maneira geral ... acho que está vivendo um momento crítico ... né ... de baixa mesmo ... de baixa inclusive da autoestima porque não tem perspectiva de trabalho ... não tem perspectiva de fazer funcionar o serviço pelo qual as pessoas lutaram tantos anos ...

BALBACHEVSKY (1995) analisando a profissão acadêmica no Brasil, afirma que as atividades de extensão levam ao envolvimento do professor com o entorno da universidade favorecendo a fragmentação do seu trabalho na academia. A autora aponta ainda a atividade de ensino como a mais extensivamente compartilhada pelos professores. Porém como vimos, não podemos afirmar que o ensino seja compartilhado na FSP.

BAPTISTA (1997) examinando o movimento da identidade coletiva do professor universitário ao estudar a história do ensino superior no Brasil, define cinco momentos característicos na construção da identidade do professor, ou seja, aqueles momentos em que as mudanças tornam-se mais evidentes. Destacaremos a seguir dentre os aspectos apresentados pela autora os de maior interesse ao nosso estudo:

- primeiro momento, "que se inicia com a introdução dos primeiros cursos superiores no Brasil (ainda no período colonial) e se estende até a década de 30. O que unifica a ação dos professores e, consequentemente, sua identidade, é a intenção de 'transmitir um saber' com a finalidade de 'formar bons professores'".

- segundo momento, "quebra da exclusividade da "transmissão do saber" como objetivo único da atividade docente. A "criação do saber passa a ser também um dos objetivos do ensino e, consequentemente, ao catedrático se atribui também o papel de pesquisador. A partir desse momento a unicidade da identidade coletiva deixa de existir; há professores que assumem os dois objetivos ... Assim como com os indivíduos, essas diversificações também ocorrem no nível das 
instituições".

- terceiro momento, que vai de 1950 a 1964. A principal mudança que se observa na identidade coletiva diz respeito a uma nova fonte de identificação para a atividade do professor: é a sua preocupação com a realidade social, que exige não só transformações na universidade, mas também no contexto social mais amplo.

- quarto momento, que tem o golpe de 64 como marco inicial. "Neste contexto passou a ser valorizado um 'padrão único' de identidade a ser assumido pelos professores. $O$ 'saber' (enquanto transmissão e/ou criação) é então considerado exclusivamente um saber instrumental, com o objetivo de promover o desenvolvimento segundo um modelo internacional de capitalismo".

- quinto momento "Hoje há pelo menos duas características marcantes na 'identidade coletiva':

a) A vivência de uma mesmice que impede sua própria superação. Mesmice porque são identidades que, ao serem incorporadas, não supõem uma compreensão dos seus determinismos, de seu papel na realidade atual, e não pressupõem a existência de um projeto de retomada autônoma da identidade". Citando Ciampa, a autora afirma que "nesse momento histórico a identidade está refletindo a estrutura social, principalmente conservando-a, e não contribuindo para modificá-la".

b) "Uma pulverização extremada de modelos de identificação, que provoca o aparecimento, também extremado, de particularidades. Essa pulverização impede que novas legitimações sejam desenvolvidas, impossibilitando a superação $e$, consequentemente, a criação de um projeto comum de evolução da identidade do grupo profissional".

Essa análise de BAPTISTA (1997) sobre o quinto momento reflete bem o contexto da Faculdade encontrado no nosso estudo. 
O comportamento individualista nas relações psicossociais foi identificado nas atividades de pesquisa dos professores, suas razões podem advir de várias ordens, destacamos que podem decorrer da própria estrutura universitária ou de características mais peculiares da história de vida profissional desses sujeitos.

(7 P) $P$ : você se sente fazendo parte de algum grupo de pesquisa aqui na faculdade?

R: sim ... Embora o nosso grupo ... quando eu falo grupo é o pessoal do departamento, mas não é o departamento ... o grupo de entomologia seja um grupo muito individual, muito individualista, e cada um por si e Deus por todos, mas ... eu sempre tive um grupo que eu formei com $D$., quer dizer, há muitos anos, mais de 10 anos que formou ... eu e o $D$. somos um pequeno grupo. E hoje o que está havendo é que o $A$. entrou nesse grupo e foi legal e o A. está coordenando um projeto no qual ele envolveu o grupo, eu e o $D$. ... e aí a gente praticamente forçou que a $E$. também entrasse nesse grupo ... então estou vendo que as perspectivas são muito boas da gente, pela primeira vez, trabalhar em conjunto, em partes iguais, com a sua individualidade, e com a sua ... e com tudo ... com toda a sua capacidade ... produtiva, improdutiva, tudo ... de bom e de ruim. $E$ isso não aconteceu nunca antes. Com o F., infelizmente, a gente não conseguiu, a gente trabalhava para o F., trabalhava com o F., para o $F$.. E nunca junto com $F$., não no mesmo nível ... ele sempre num nível muito mais elevado ... se sentia num nível mais elevado. E nós sempre como aqueles subalternos que estão produzindo para ele.

(6 A) Repartir conhecimento entre os cientistas não é coisa fácil. 0 pessoal não sabe ... eu vou trabalhar com saúde da mulher, você também ... agora meu pedaço ... Tudo bem, pode ter trocas de coisas ... Não, as pessoas são exclusivistas, só eu posso fazer isso ... só você pode ........) e a minha sensação é que os pesquisadores estão tornando cada vez mais egoístas ...Eles têm uma certa razão, de uma certa maneira ... porque eu acho que sofreram durante muito tempo a questão do roubo intelectual das idéias, e que essa é uma coisa muito constante ... Hoje você fala alguma coisa, e a outra pessoa que é dona da sua idéia, né. Então, eu acho que com isto, o cientista, o produtor de conhecimento, ele se torna muito fechado ... então ele só divulga a sua idéia quando ele tem certeza do que ele está falando ou quando ele já pode tornar público aquilo que pensa, e aí ele aparece como um especialista. Além do que ele é cioso, então ... - por que só ela está falando aquilo?, eu também falo aquilo ... eu também devia estar ... também deviam estar me chamando ... por que não eu? -, então as pessoas estão ciosas daquilo que falam, e acham que muitas vezes sós eles que sabem aquilo ... que o outro está falando besteira. Então, por exemplo é muito difícil aqui você trazer pessoas para um seminário que trabalham sobre o mesmo assunto seu mas que debatem de uma outra vertente ... 
Essa situação pode estar sendo agravada pela ausência de espaços informais ou formais - de discussão entre os professores.

(5 P) Agora, enquanto linha de pesquisa, enquanto ... eu nunca tive uma discussão a respeito disso aqui na escola. Tanto é que eu sinto que eu venho definindo a minha linha de pesquisa muito por uma iniciativa própria e muito pela demanda dos próprios orientandos, vai se formulando um tipo de demanda que ficou chamada assim lato senso de problemas emergentes em saúde pública, acho que depois através daquele encaminhamento conjunto de projetos para a FAPESP, que é um outro programa da universidade, que tem uma cara, né, saúde e cidadania, portanto com outras pessoas aqui dentro da escola. Mas é muito ... é uma iniciativa muito particular, muito própria. Não sinto que tenha tido ... que tenha uma ... que a escola tenha discutido isso ...

A busca de encaminhamento às suas questões leva esse professor a se referir à FAPESP, de maneira diversa da usual, como uma instituição que acaba, ao julgar seus projetos de pesquisa, estabelecendo um diálogo com ele, dando um retorno que a FSP parece não dar.

Segundo alguns professores a "desorientação ou bagunça" no cotidiano dos cursos é confundida com "excesso de liberdade" dos professores, o que pode estar associado a um duplo comando da pós-graduação - os departamentos e a CPG, ou melhor a "nenhum" comando.

Um problema identificado por nós como não facilitador da coordenação de atividades didático-científicas da pós-graduação é a composição da CPG. Seguindo o Estatuto da USP, e como já citamos na introdução deste trabalho, ela é formada por dois representantes de cada departamento da Faculdade. Porém eles não têm nenhuma função de coordenação relacionada a área de concentração e em muitos momentos nem legitimação. Sobre este fato, assim se expressa um professor:

(2 P) ... Mas veja só, o que seria uma comissão, um colegiado?, no caso da pós graduação, né. Os representantes do Departamento, ao discutir no colegiado eles estão suficientemente amparados numa discussão mais profunda, permanente, dos temas ali do Departamento, ou muitas vezes eles tem quase que criar por si só, um esforço muito grande, etc ... etc ... posições ou coisas que marcam o conhecimento deles, a dedicação, o interesse, da honestidade do trabalho ... esse tipo de coisas do que propriamente ser o reflexo de uma posição ... Então, essa coisa que eu falo, quer dizer, essa relação entre as decisões e o 
conjunto institucional ... então esse é um outro componente que já está se mexendo, está certo ... mas que precisaria ser aprimorado. Não sei se fui claro ...

O mesmo professor, se destacou diante dos outros depoimentos, na ênfase dada ao desejo de participação mais efetiva dos docentes no cotidiano da escola, ... foi uma decisão da CPG, da qual eu não participo (2P).

Chamamos a atenção para o fato de que encontramos nos depoimentos ausência de referência as áreas de concentração. Este é um aspecto que merece aprofundamento de estudo. Segundo o Regimento da USP ela se constitui no campo específico de conhecimento, no objeto principal dos estudos e atividades de pesquisa do aluno. Neste sentido causa estranheza o distanciamento entre esta questão e os depoimentos encontrados uma vez que as áreas em príncipio expressariam a identidade da pós-graduação em saúde pública. Ao falar sobre a condução dos cursos tanto alunos como professores se referiram aos departamentos e a CPG, e quando fizeram suas referências, essas instâncias foram citadas como estruturas abstratas.

Nesse contexto as atividades didático científicas se diluem entre os departamentos parecendo não existir uma preocupação com sua institucionalização pelo corpo docente da escola.

As diretrizes da pós-graduação vão ficando deficientes e "perdidas "entre os departamentos e a CPG. Para os professores a CPG é um órgão burocrático e os departamentos não são vistos pelo professor como a instância que poderá articular as atividades de ensino, pesquisa e extensão; mesmo porque o próprio estatuto da USP reforça a separação dessas atividades. A representação departamental nos diferentes colegiados não possibilita a participação do conjunto de docentes deslegitimando assim sua representação e não propiciando a prática de debate e reflexão sobre as questões do cotidiano da escola..

(8A) ... por mais que os chefes de departamento tentassem dizer que essa discussão tinha sido feita nos departamentos, eu ouvi chefes de departamento chegando na reunião sem nem saber o que estava sendo discutido, sabe. Então, assim ... é ser inocente acreditar na retórica que a discussão está sendo feita nos departamentos.

Mas não é um problema da Saúde Pública, é um problema de poder da universidade, onde (expressão inteligível) os titulados, onde os 
professores com menos grau de ascensão na carreira acadêmica não tem vez, não tem voto ... onde ... tem essa discriminação ... a USP é a universidade mais conservadora, mais antidemocrática que a gente tem.

(5P) ... a $F$. já defendeu então eu já ... (ri) ... eu já posso ... já tirei a minha carta de alforria, né. Então, em primeiro lugar eu sinto o seguinte: não sei a experiência de outras unidades, não sei como acontece, mas, eu sinto que você faz um pouco da tua linha de pesquisa ... você faz a tua linha de pesquisa, faz a tua forma de orientar, tua forma de dirigir, como na base da vocação pessoal. Estou falando vocação pessoal porque eu não sinto que tenha ... que exista uma discussão, né, que existam interlocutores aqui na Faculdade, interlocutores quer no sentido de discutir o que queiram da pós graduação, que se estabeleçam. Eu sinto o seguinte: a relação que durante esses anos eu acho que de três a quatro anos eu comecei a orientar, quer dizer, eu sinto o seguinte: que todo tipo de discussão ou de orientação, sempre foi orientação burocrática, quer dizer, é como o que se deve cumprir, o que não se deve cumprir, o que se deve fazer, o que não se deve fazer, prazos. Toda a relação institucional para mim parte de uma relação burocrática. E uma relação burocrática que não ... que muitas vezes, quer dizer, que ela reflete uma forma que da comissão de pós graduação lidar, legislando, em geral com caráter limitativo, restritivo ou restringindo. $E$ eu sinto que do ponto de vista técnico, do ponto da linha de pesquisa, fica muito a critério do orientador (...) a relação com a CPG é uma relação burocrática, mas esse burocrática eu acho que ela tem ... por isso que talvez eu sinta que é o órgão com quem mais se dê uma interlocução dentro da escola, ainda que não seja a esperada. (...) olha, eu acho que tem alguns interlocutores também dentro da Faculdade, né, quer dizer, alguns interlocutores na área, enfim ... se essa história de área existe ou não (...) na área ... nós somos dois docentes na área e alguma coisa a gente troca. Algumas outras áreas do Departamento tem algum contato mais esporádico, assim ... áreas do Departamento, educação ... também pessoas ... independente a área. Eu sinto que existe uma afinidade maior entre pessoas e pessoas que certamente estão em algumas áreas, né, mais correlatas. E fora do Departamento também ...

(6 P) as pessoas acham que os departamentos é que têm mais força. $\mathrm{Na}$ estrutura atual as condições são de supra departamentos. (...) com a nova $L D B$ em que as universidades não precisam estar estruturadas nos departamentos, você pode ter uma estruturação tipo curso (...) não acho que seja melhor, não pensei a respeito ... mas poderia até ter uma estrutura com áreas de especialidade, uma estrutura de cursos mesmo ... (...) Eu acho que os departamentos vão tender a mudar muito de figura, eles não tem mais o poder que eles acham que tem. Ainda eles tem, né ... ainda tem algumas coisas regimentalmente que fortalecem os departamentos ... mas são facilmente quebráveis.

(6 P) ... é como se a pós-graduação estivesse à serviço do orientador e do aluno. É essa visão que os docentes, alguns docentes, e vários alunos 
acham que a Pós-Graduação é. Eles não vêem a Pós-Graduação como instância superior aos alunos e aos docentes. Eles vêem a PósGraduação como um meio burocrático deles atingirem os seus objetivos. Só que é a Pós-Graduação que credencia os professores, é a Pós-Graduação que é responsável pelo aluno, né ... então qualquer papelzinho que sai de lá se não tiver a minha assinatura não tem validade, né.

$P:$ De onde você acha que vem essa maneira de ver?

$R$ : eu acho que é um mito da nossa independência, nós docentes somos muito independentes e acho que a gente passa isso para o aluno, né. Nós somos os bons, nós ditamos as regras dos departamentos. Hoje eu tive uma discussão séria na Pós-Graduação em que eles colocavam o Departamento acima da Pós-Graduação, - mas vocês estão enganados. O Departamento não está acima da Pós-Graduação. O Departamento é um intermediário, mas quem determina é a Pós-Graduação -, quem define ... Lógico que nós vamos ouvir o colegiado e seus orientadores, que fazem parte do Departamento.

(4 P) Infelizmente o nosso Departamento ele carece de uma uniformização, diria até melhor, uma unidade, uma filosofia relativamente ao conceito de saúde ambiental, à intervenção do engenheiro dentro das questões ambientais, a necessidade do engenheiro se conectar, entender e se fazer entendido pelos outros profissionais.

As próprias indefinições sobre responsabilidades, limites etc departamentais, não são questões só da FSP e muito menos só da USP. Este tema presente na Lei de Diretrizes e Bases da Educação Nacional - Lei oo 9394/96 (LDB), vem desde 1996 em sua aprovação, mostrado ser polêmico e de difícil condução no contexto universitário brasileiro.

Além das questões referentes à organização, estrutura e dinâmica dos cursos um professor entrevistado discute proposta de trabalho a partir de um outro recorte - questionando a subordinação econômica.

(2 P) ... acho que a Faculdade ela está num processo de revisão e esse processo de revisão ele realmente ... se faz por fatores internos e externos a ele, né ... Tem um lado dos professores ... e tem outro lado que é da sociedade como um todo, dos órgãos financiadores ... eu acho que tudo isso remete a se ver por que ... Mas eu acho que na Faculdade ... acho que o lado positivo é que a gente nota que está havendo uma movimentação, sim mas, objetivamente respondendo a sua pergunta, existe uma certa insatisfação ou preocupação de uma grande parcela dos docentes em rever esse processo, o que eu acho muito salutar. E isso, repetindo aquilo que eu falei, sem nenhum demérito aos trabalhos anteriores ... pelos que já se aposentaram ou por nós mesmos que estamos aqui . (...) Até a própria revisão do departamento ... 
começou ... Porque veja só, tem um pouco o F. que chama a atenção para isso ... eu acho que ele está até com razão: não é ... porque assim como está se discutindo a pós graduação, tem outros cursos ... especialização, outros cursos ... tem a linha de pesquisa, tem essa coisa toda. Então, eu acho que essa revisão da pós graduação e dos outros cursos ... se você colocar ... você tem que ver, nós temos que ver, está certo?, quais são as falhas do nosso processo de trabalho como faculdade, como departamento, como os órgãos colegiados, etc, na maior ou menor integração da Faculdade, na própria experiência, na própria articulação que eles tem, e o quanto isso reflete nessa possível desarticulação do nosso produto final, o curso de especialização, o curso de pós graduação, etc. Ou seja, não buscar as causas apenas nos efeitos. Por isso que eu acho que essa revisão que está havendo no departamento, parece que está acontecendo em outros departamentos, e na própria revisão que a pós graduação começa a fazer, etc ... eu acho que são passos nesse sentido, por que?, porque você não vai apenas impor - vamos então rever as disciplinas de pós graduação -, você tem que rever o curso de pós graduação, como é que nós estamos como participantes, qual é o nosso papel, etc ... nosso processo de trabalho, etc. E para isso, qual é a pós graduação que nós queremos ... quer dizer, não o que um ou outro quer, etc ... Quer dizer, é quase que rever mesmo o perfil da Faculdade, o papel da Faculdade ... para ver se ela quer ter um outro perfil, um outro papel, um outro componente, etc.

Lembramos que a referência por esse professor ao processo de revisão que está havendo na FSP, decorre de uma "pressão" da Universidade quando a mesma desencadeou o processo de avaliação departamental em todas as suas unidades.

Observamos também na FSP que um conjunto de questões tem trazido para o corpo docente uma inquietação, provavelmente advinda da não explicitação de um projeto institucional, diante de "pressões" encaradas como externas à Faculdade - crise no ensino superior; avaliações departamentais, avaliações CAPES, e exigências da FAPESP e CNPq para concessão de recursos. Questões que pareciam distantes do seu cotidiano agora devem ser, nesse cenário, refletidas criticamente. 


\section{Capítulo IV - CONSIDERAÇÕES FINAIS}

Buscamos neste estudo compreender as peculiaridades da pósgraduação em saúde pública na FSP. Consideramos que a formação em saúde pública possui um objeto complexo, e caracteriza-se por ser pós-graduada, interdisciplinar e multiprofissional.

Situamos a FSP como uma escola criada para a formação de profissionais para os serviços de saúde e que teve no Curso de Especialização em Saúde Pública a sua "marca mais forte para o modelo de formação do sanitarista", treinando mão de obra para atuar junto aos organismos governamentais e mercado de trabalho.

Foi a primeira escola do país a iniciar a pós-graduação strictu senso em saúde pública, destinada à formação de professores para o magistério superior e de pesquisadores em saúde pública.

Com exigências tão distintas, do treinamento à reflexão conceitual, começamos a encontrar, no nosso ponto de vista, o início dos dilemas vividos hoje pela Faculdade, e que vem se tornando mais agudos.

Se a identidade da Faculdade vinha se dando com a interlocução, com o serviço público de saúde, Ministério da Saúde, secretarias de saúde, organismos internacionais voltados a saúde, novas identidades foram sendo construídas no correr dos anos devido a nova referência institucional com o Ministério da Educação.

A solicitação desse setor acaba chegando para o professor como "pressão" ou normas a serem cumpridas, que o afastam de pensar que ele, o professor no conjunto de sua categoria, deverá construir o projeto de ensino de saúde pública opondo-se como foi observado e revelado pelos sujeitos do estudo, aos vários projetos individuais ou de pequenos grupos, pertinentemente identificado pela aluna $(5 \mathrm{~A})$ como "...salve-se quem puder...".

$\mathrm{Na}$ análise dos depoimentos e documentos consultados, identificamos na 
FSP uma ausência de direcionalidade sobre seus destinos. No cotidiano do curso percebemos processos que demonstram essa fragilidade:

- Os critérios para seleção de alunos não são claramente explicitados no que diz respeito ao perfil de aluno desejado e as próprias finalidades dos cursos - qualificação profissional, preparo de professores e pesquisadores?

- A estrutura curricular foi considerada pouco flexível, "desarticulada", centrada no professor. $O$ desenvolvimento da estrutura curricular apresenta "um abismo" entre a fase de cumprimento de créditos disciplinares e a fase de produção da pesquisa. A primeira não alimenta a segunda. Podendo-se ainda sentir durante a primeira uma divisão entre as disciplinas obrigatórias e as eletivas. O quadro de disciplinas eletivas tem oferta irregular em termos de horário, ano em que é oferecida, e número de créditos; possuindo composição temática diversa.

- Os alunos consideram o conteúdo das aulas instrumental e com enfoque predominantemente biológico. Ressentem-se de atividades mais reflexivas que permitissem uma visão crítica da realidade dos serviços de saúde e os preparassem para a realização da tese ou dissertação. Parte dos alunos concorda mas considera importante esse conteúdo, são alunos que vêem nas disciplinas de pósgraduação oportunidade para reciclagem e atualização.

- A prática dos professores foi definida pelos entrevistados como sendo fragmentada, isolada, sem um projeto comum. Porém com o reconhecimento da existência de valores individuais, sendo perceptíveis a partir da definição de linhas de pesquisa - feitas com "base na vocação pessoal" - na composição do quadro de disciplinas eletivas - "aleatório".- na forma de orientar - "quando quer e como quer". O professor não tem a CPG como interlocutora para discutir linhas de pesquisas e o ensino na pós-graduação; e muitos menos se vê como participante na construção da identidade institucional. 
A CAPES, desde que iniciou seu processo avaliativo, tem feito críticas aos cursos da Faculdade. Ao longo dos anos esses críticas têm sido semelhantes excesso de disciplinas, linhas de pesquisas não definidas, as vezes confundidas com projetos de pesquisa, excessivo tempo para titulação e baixa produção científica orientador/orientando. Apesar das críticas, a FSP ao longo desses anos, parece não ter procurado atendê-las e nem questionar os critérios de avaliação, caso julgasse que estes não fossem pertinentes à nossa área.

A questão - a FSP deve se adaptar ao modelo CAPES de pós-graduação ou a pós-graduação se adaptar à FSP - parece nunca ter sido colocada.

Algumas propostas estão sendo discutidas na FSP neste momento, mas consideramos que trazem soluções pontuais não chegando a essência da nossa questão. As alterações das normas dos cursos de pós-graduação vêm mais claramente nos últimos anos, sendo moldadas pelas exigências da CAPES. São mudanças pontuais que corrigem efeitos e não causas. Por exemplo, tempo médio para conclusão do curso é longo, isto leva a mudança das normas estabelecendo tempo máximo de três anos e reduzindo os créditos em disciplinas obrigatórias, sendo estas praticamente as únicas mudanças para reduzir o tempo de duração do curso. Não consideramos que esta decisão respeite as peculiaridades do nosso corpo discente e do nosso curso.

(8 A) ... a redução dos prazos, né, que foi aprovado ... que agora 0 mestrado é quatro anos e doutorado cinco. E aí o que a gente verificou? Que algumas unidades, que acho super contraditório, que é a Faculdade de Saúde Pública e a Faculdade de Filosofia e Letras ... que eles fizeram uma opção por um mestrado de três anos ... e que são justamente aquelas unidades onde você tem um histórico de programas longos. Tanto é que é um tratamento de choque, sem considerar a inserção, conteúdo e estrutura que é a faculdade tem na pós graduação, né. Então, pensa em nosso mestrado de três anos ... eu consigo fazer pelas características que eu tenho, né, de dedicação exclusiva, de querer fazer do mestrado uma etapa para o doutorado ... de ter um objetivo. Agora, quem está em serviço, fazendo também a pós graduação, e não unicamente a pós graduação, fazer em três anos ... com a carga horária de disciplinas que a gente tem aqui ... as obrigatórias ... com o distanciamento que a gente vê entre orientador e orientando, né, com a baixa absorção dos pós graduandos pelos departamentos ... é complicadíssimo, né. 
Não identificamos um projeto claro ou explícito para a pós-graduação da FSP, parece haver uma ausência de definição institucional diante das mudanças ocorridas principalmente na área da saúde e da educação. A saída encontrada pelo professor foi a individualização da questão na tentativa de sobreviver.

SAUL e ABRAMOWICZ (1997) discutindo a avaliação da pós-graduação conduzida pela CAPES, destacam:

"O poder mágico das letras que classificam os cursos cada vez mais é fetichizado, extrapolando o âmbito dos programas e atingindo a sociedade como um todo através da imprensa"

"O financiamento da pós-graduação (bolsas e infra-estrutura) continua atrelado aos conceitos e cada vez mais é operacionalizado através de índices padronizados e sofisticados. Dessa forma, não considerando a historicidade e singularidade dos cursos, reforça injustiças e acentua a penalização dos penalizados".

Uma reação que se observa é a de responder "a pressão" para obter mais recursos ou no mínimo manter os recebidos.

(6 P)... eu acho que a CPG vai tender a voltar as vacas magras, que ... de repente a CAPES e CNPq resolvem não dar a tal da taxa de bancada

(6 P) não é uma tendência livre, não ... Eu acho que ela é bem dirigida. Na hora que você só consegue recursos se estiver ligada a uma linha de pesquisa, a um núcleo de excelência ... estão o próprio sistema de fomento está obrigando os docentes ... Eles não querem docentes individualistas, individuais ... mas eles estão formando docentes cada vez mais ... o núcleo de excelência ... você teoricamente teria que estar interelacionando com outra pessoa, mas essa outra pessoa, mas essa outra pessoa em geral não é da sua instituição, é de outra e de preferência de fora. Então, você forma você com seu monte de alunos ... então nó temos um convênio internacional, núcleo de excelência, não temos nada ... e sim cada um trabalhando individualmente com seus alunos ...

O risco é o de desenvolver um raciocínio de ensino subordinado às questões econômicas, e de submissão à CAPES pela sobrevivência institucional.

Consideramos importante a compreeensão dos limites e posssibilidades da nova LDB que traz mudanças que podem afetar o repensar da FSP; e a discussão com o sistema de ensino superior do país - parceiros na busca de 
soluções mais coletivas para as questões referentes à qualidade do ensino brasileiro.

A superação da situação da FSP talvez possa vir com a construção do seu projeto de identidade na saúde pública, da discussão do que ela pretende como perspectiva futura, lembrando a sua responsabilidade em ser uma das poucas alternativas no Brasil para a formação de professores e pesquisadores em saúde pública.

Talvez o primeiro passo seja repensar o seu objeto de intervenção hoje, buscar clareza do nosso objeto - saúde pública. 


\section{REFERÊNCIAS BIBLIOGRÁFICAS}

\{ABRASCO\} Associação Brasileira de Pós Graduação em Saúde Coletiva. Relatório do Encontro Nacional de Pós-graduação em Saúde Coletiva e Reforma Sanitária. Estudos de Saúde Coletiva 1988; 5: 125-126.

\{ABRASCO\} Associação Brasileira de Pós-graduação em Saúde Coletiva. Catálogo de pós-graduação em saúde coletiva - Brasil 1993. Rio de Janeiro: ABRASCO; 1992.

Almeida Filho $\mathrm{N}$ de. Transdisciplinaridade e Saúde Coletiva Ciência \& Saúde Coletiva 1997; 2(1/2): 5-20.

Amorim A. Avaliação institucional da universidade. São Paulo: Cortez; 1992.

Balbachevsky E. Atores e estratégias institucionais: a profissão acadêmica no Brasil. São Paulo; 1995. [Tese de Doutorado - Faculdade de Filosofia, Letras e Ciências Humanas da USP].

Balzan NC, Dias Sobrinho J, organizadores. Avaliação institucional: teoria e experiências. São Paulo: Cortez; 1995.

Baptista MTD da S. Identidade e transformação: o professor na universidade brasileira. São Paulo: Unimarco/EDUC; 1997.

Barreto ML. Qualidade da pós-graduação em saúde coletiva: avaliação da área versus avaliação dos programas. Rio de Janeiro; 1997 [Documento elaborado para a Oficina de Trabalho sobre avaliação da pós-graduação em Saúde Coletiva ABRASCO].

Benchimol JL. Manguinhos do sonho à vida: a ciência na Belle Époque. Rio de Janeiro: Fundação Instituto Oswaldo Cruz; 1990.

Bertucci LM. Saúde: arma revolucionária. Campinas: Editora da UNICAMP; 1997. 
Candeias NMF. Memória histórica da Faculdade de Saúde Pública da Universidade de São Paulo - 1918 a 1945. Rev Saúde Pública, 1984; 18 (no esp.): 2-60.

CAPES aposta no mestrado profissionalizante. Jornal da USP 1996 abr. 15-2.

[CAPES] Coordenação de Aperfeiçoamento de Pessoal de Nível Superior. Coordenadoria de Acompanhamento e Avaliação. Notas sobre a avaliação da pósgraduação. Brasília (DF); 1982.

Carvalho GI. Ensino superior: legislação e jurisprudência. São Paulo: Editora Revista dos Tribunais; 1975.

Cohn A. Nunes ED. A pós-graduação em saúde coletiva: mestrado e doutorado. Estudos de Saúde Coletiva. 1988; 5: 15 - 46.

Córdova R de A, Gusso DA, Luna SV de. A pós-graduação na América Latina: o caso brasileiro. Brasília (DF): UNESCO/CRESALC/MEC/SESU/ CAPES; 1986.

Ferreira Gonçalves FA. Moderna saúde pública. 6 ed. Lisboa: Fundação Calouste Gulbenkian, 1990.

Fleury S, organizadora. Projeto Montes Claros - a utopia revisitada. Rio de Janeiro: ABRASCO; 1995.

Gallo E. Crise teórica e crise política impactos na saúde coletiva. In: Fleury S, organizadora. Saúde Coletiva? Rio de Janeiro: Relume-Dumará; 1992. p 67-74.

Georgen P. Pós-Graduação no cenário dos novos paradigmas epidemiológicos. Revista de Ciências Sociais. 1997; 10(21): 35-62.

Goldenberg P, Schenkman S. Os egressos de pós-graduação em saúde coletiva: construindo um perfil. Ciência \& Saúde Coletiva; 1997; 2(1/2): 117-141.

Kisil M. Educação em administração de saúde na américa latina: a busca de um paradigma. São Paulo: Faculdade de Saúde Pública da Universidade de São Paulo; 1994. (AdSaúde-Série Temática, 2). 
Labra ME. O movimento sanitarista nos anos 20. Da conexão sanitária internacional à especialidade em saúde pública no Brasil. Rio de Janeiro; 1985. [Dissertação de mestrado - Escola Brasileira de Administração Pública da FGV].

Loyola MA. O descompasso da pós-graduação no Brasil. [apresentação] INFOCAPES. 1994; 2 (2): 5 - 6.

Lüdke $M$, André MEDA. Pesquisa em educação: abordagens qualitativas. São Paulo: EPU; 1986.

Machado MH, organizadora. Profissões de saúde: uma abordagem sociológica. Rio de Janeiro: Fundação Oswaldo Cruz; 1995.

Martins CL, Vasconcellos MP. Perfil dos alunos dos cursos de pós-graduação mestrado e doutorado - FSP/USP do período de 1973 a 1995. São Paulo; 1996. [Relatório de Estudo realizado na Faculdade de Saúde Pública da USP].

Martins RC de R. A pós-graduação no Brasil: uma análise do período 1970-90. Educ. Bras. 1991; 13(2): 93-119.

Medici AC, Machado MH, Nogueira RP, Girardi SN. O Mercado de Trabalho em Saúde no Brasil: estrutura e conjuntura. Rio de Janeiro: ENSP; 1992.

Merhy EE. A Saúde Pública como Política: um estudo de formuladores de políticas. São Paulo: HUCITEC; 1992.

Minayo MC de S. Pós-Graduação em saúde coletiva: um projeto em construção. Ciência \& Saúde Coletiva. 1997; 2(1/2): 53-71.

Minayo, MC de S, organizadora. Pesquisa social. São Paulo: Vozes; 1993.

Ministério da Saúde. Coordenação Geral de Desenvolvimento de Recursos Humanos para o SUS. A questão dos recursos humanos nas conferências nacionais de saúde (1941-1992). Cad. RH Saúde 1993; 1(1): 147 -212.

Ministério da Saúde. Coordenação Geral de Desenvolvimento de Recursos Humanos para o SUS. 2 ${ }^{\text {a }}$ Conferência Nacional de Recursos Humanos para a Saúde: relatório final. Cad. RH Saúde 1994 a; 2 (1): 1-59. 
Ministério da Saúde. Fundação Oswaldo Cruz. Escola Nacional de Saúde Pública. Pós-Graduação stricto sensu: mestrado e doutorado. Rio de Janeiro; 1994 b. [Catálogo].

Nunes ED. Saúde coletiva: revisitando a sua história e os cursos de pós-graduação. Ciência \& Saúde Coletiva, 1996; 1(1): 55 -69.

Nunes ED, Costa PS da. Estrutura Curricular: núcleo básico comum. Rio de Janeiro; 1997 [Documento elaborado para a Oficina de Trabalho sobre avaliação da pós-graduação em Saúde Coletiva - ABRASCO].

Oliveira FB de. Pós-graduação educação e mercado de trabalho. Campinas: Papirus; 1995.

Paim J, Almeida Filho N de. Saúde Coletiva: uma "nova saúde pública" ou campo aberto a novos paradigmas? Rev Saúde Pública 1998; 32(4): 299-316.

Palma JJL da. Os trabalhadores em saúde: agentes, práticas e instituições de saúde em São Paulo, 1917-1945. São Paulo; 1996. [Dissertação de Mestrado Faculdade de Medicina da USP].

Ponce BJ. Avaliação institucional como critério de qualidade social. In: Reflexões sobre revisão institucional curricular; 1994 Nov 11; São Paulo; Universidade de São Paulo. Faculdade de Saúde Pública. p. 1-35.

Ribeiro MAR. História sem fim ... inventário da saúde pública. Campinas: Editora da UNESP; 1993.

Rosen, G Uma História da Saúde Pública. São Paulo: UNESP/HUCITEC/ ABRASCO; 1994.

Santana JP, coordenador. Regulação do Trabalho em Saúde. OPS - Série Desenvolvimento de Recursos Humanos 1994.

Saul AM. Avaliação emancipatória: desafio à teoria e à prática de avaliação e reformulação de currículo. 2 ed. São Paulo: Cortez; 1994. 
Saul AM, Abramowicz M. Avaliação da pós-graduação: superamos os limites? Educ. Bras. 1997; 19(38): 111-119.

Saviani D. Ensino público e algumas falas sobre universidade. $5^{\mathfrak{a}}$ ed. São Paulo: Cortez; 1994.

Saviani D. Equidade e qualidade em educação: equidade ou igualdade? PUCViva Revista. 1998; 2: 17-21.

Severino AJ. Metodologia do trabalho científico. 19ª ed. São Paulo: Cortez; 1993.

Spink MJ. Desvendando as teorias implícitas: uma metodologia de análise das representações sociais. In: Guareschi P, Jovchelovitch S, organizadores. Textos em representações sociais. 2 ed. Rio de Janeiro: Vozes; 1995.

Tanaka AC. Perfil da demanda aos cursos de pós-graduação, de 1996, na área de saúde coletiva. Ciência \& Saúde Coletiva. 1997; 2(1/2): 108-116.

Triviños ANS. Introdução à pesquisa em ciências sociais - a pesquisa em educação. São Paulo: Atlas; 1987.

Universidade de São Paulo. Comissão Especial de Regimes de Trabalho. Regimento interno da CERT - Legislação dos regimes de trabalho Afastamento do corpo docente. São Paulo; 1989 [Coletânea legislativa].

Universidade de São Paulo. Faculdade de Saúde Pública. Catálogo de cursos de pós-graduação, São Paulo, 1994. (Catálogo/FSP, série 3).

Universidade de São Paulo. Faculdade de Saúde Pública. Cursos de especialização em saúde pública. São Paulo, 1993. (Catálogo/FSP, série 4).

Universidade de São Paulo. Faculdade de Saúde Pública. Informações Gerais, São Paulo, 1989. (Catálogo/FSP, série 1).

Vasconcellos MP, coordenadora. Memórias da Saúde Pública: a fotografia como testemunha. São Paulo: HUCITEC/ABRASCO; 1995.

Vasconcellos MP, Narvai PC. Especialização em Saúde Pública: alunos da USP no período de 1985 - 1994. Ciência \& Saúde Coletiva. 1997; 2(1/2): 154-163. 
Vieira S. Como escrever uma tese. $4^{\mathrm{a}}$ ed. São Paulo: Pioneira; 1998.

Wanderley LEW. O que é universidade. $2^{\underline{a}}$ ed. São Paulo: Brasiliense; 1984.

Wolnenec E, Marin HL. A informação da administração na Universidade de São Paulo. Educ. Bras. 1988; 10(21): 213-224. 
ANEXOS 


\section{Anexo 1}

Linhas de pesquisa do Departamento de Prática de Saúde Pública e do Departamento de Nutrição da FSP/USP 


\section{LINHAS DE PESQUISA POR ORIENTADOR DO DEPARTAMENTO DE PRÁTICA DE SAÚDE PÚBLICA}

\section{INFORMAÇÕES PARA INSCRIÇÃO DE CANDIDATOS AO CURSO DE PÓS- GRADUAÇÃO EM SAÚDE PÚBLICA - 1998.}

\begin{tabular}{|c|c|}
\hline DOCENTES & LINHAS DE PESQUISA \\
\hline Prof. A & Promoção de saúde e envelhecimento - Autocuidado e Envelhecimento. \\
\hline Prof. B & Administração de serviços de saúde - Qualidade em serviços de saúde. \\
\hline Prof. C & $\begin{array}{l}\text { HIV: Aspectos Psicosociais - Representações da maternidade na adolescência } \\
\text { - Cultura Organizacional - Elaboração novas estratégias para pesquisa em } \\
\text { saúde na promoção, planejamento, administração e Vigilância Sanitária. }\end{array}$ \\
\hline Prof. D & $\begin{array}{l}\text { Política e Sistemas de Saúde - Modelo de atenção e práticas sanitárias - } \\
\text { Organização/Administração de serviços de saúde - Teorias e métodos de } \\
\text { planejamento em saúde. }\end{array}$ \\
\hline Prof. E & $\begin{array}{l}\text { Políticas Públicas e Sociologia da Administração Pública em Saúde; Políticas } \\
\text { Saudáveis; Aparelho de Estado: Plano Diretor; Agentes Públicos; Proposta de } \\
\text { Reforma Constitucional; Medidas Provisórias; Organizações Sociais; } \\
\text { Organização do Setor Saúde no Município de São Paulo: PAS; Funções } \\
\text { Públicas Indelegáveis; Modelos. }\end{array}$ \\
\hline Prof. F & $\begin{array}{l}\text { Controle de Qualidade de Alimentos - Vigilância Sanitária - Inspeção Sanitária } \\
\text { de Produtos de Origem Animal. }\end{array}$ \\
\hline Prof. G & Saúde Feminina: Saúde e Gravidez; Menopausa. \\
\hline Prof. $\mathrm{H}$ & $\begin{array}{l}\text { Prevenção da cegueira: fatores sócio-comportamentais - Fatores } \\
\text { comportamentais: relacionados ã prevenção da AIDS. }\end{array}$ \\
\hline Prof. I & $\begin{array}{l}\text { Fatores sociais na saúde (saúde em geral) - Análise da produção científica em } \\
\text { saúde pública. }\end{array}$ \\
\hline Prof. J & Tabagismo. \\
\hline Prof. K & Protozoologia Médica \\
\hline Prof. L & $\begin{array}{l}\text { Aspectos Soroepidemiológicos aplicados ao estudo da esquistossomose e de } \\
\text { outras doenças parasitárias - Vigilância de doenças parasitárias. }\end{array}$ \\
\hline Prof. M & $\begin{array}{l}\text { Zoonoses - Legislação Sanitária - Controle Sanitário de Alimentos - } \\
\text { Administração de Vigilância Sanitária. }\end{array}$ \\
\hline Prof. N & $\begin{array}{l}\text { Higiene, Proteção e Vigilância Sanitária da carne, do leite e dos produtos } \\
\text { derivados. }\end{array}$ \\
\hline Prof. $\mathrm{O}$ & $\begin{array}{l}\text { Saúde e Doença na mídia - Desenvolvimento de Crianças e Adolescentes - } \\
\text { Representação Social da Saúde e Doença - Metodologia de Pesquisa em } \\
\text { Saúde. }\end{array}$ \\
\hline Prof. P & $\begin{array}{l}\text { Administração de Serviços de Saúde - Planejamento e Avaliação de Serviços } \\
\text { de Saúde. }\end{array}$ \\
\hline Prof. Q & Promoção/Educação da Criança/Jovem em Idade Escolar. \\
\hline Prof. $\mathrm{R}$ & $\begin{array}{l}\text { Hipertensão e Gravidez - Saúde da Mulher - Reanimação Cardiopulmonar na } \\
\text { Gravidez - Cardiopatia e Gravidez. }\end{array}$ \\
\hline Prof. S & $\begin{array}{l}\text { Políticas Públicas e Reforma do Estado - Sistemas de Saúde - Administração } \\
\text { de Serviços de Saúde - Recursos Humanos em Saúde. }\end{array}$ \\
\hline
\end{tabular}




\begin{tabular}{|c|c|}
\hline DOCENTES & $\begin{array}{ll}\text { LINHAS DE PESQUISA } \\
\end{array}$ \\
\hline Prof. T & $\begin{array}{l}\text { Administração de Serviços de Saúde - Gerência Estratégica - Simulação em Serviços } \\
\text { de Saúde. }\end{array}$ \\
\hline Prof. U & $\begin{array}{l}\text { Métodos e Estratégicas em Educação em Saúde e em Educação Ambiental - Recursos } \\
\text { Audiovisuais - Trabalho com Grupos. O Grupo em Saúde Pública - Técnicas de } \\
\text { Trabalho em Grupo - Educação Ambiental: Conceitos, princípios, objetivos, histórico - } \\
\text { Educação em Saúde Escolar (Escolas e Creches) - Estudante que trabalha. Mulher } \\
\text { trabalhadora de creche: Qualidade de vida. }\end{array}$ \\
\hline Prof. V & Saúde Pública Veterinária. \\
\hline Prof. W & Administração de Serviços de Saúde. \\
\hline Prof. Y & Odontologia Preventiva - Epidemiologia Bucal. \\
\hline Prof. Z & Administração em Saúde (Global). \\
\hline Prof. Aa & Medicina Tradicional - Práticas Terapêuticas Alternativas em Saúde Pública. \\
\hline Prof. Ba & Psicologia Social e Saúde. \\
\hline Prof. $\mathrm{Ca}$ & Administração de Serviços de Saúde - Administração de Recursos Humanos. \\
\hline Prof. Da & Administração de Serviços de Saúde - Políticas de Saúde - Administração Hospitalar. \\
\hline Prof. Ea & Vigilância de Zoonoses e de Doenças Transmissíveis. \\
\hline Prof. Fa & Ecologia de Micobactérias. \\
\hline Prof. Ga & Microbiologia de Álimentos. \\
\hline Prof. $\mathrm{Ha}$ & Doenças de caráter zoonótico transmitidas por quirópteros. \\
\hline Prof. la & Saúde Pública Veterinária. \\
\hline Prof. Ja & $\begin{array}{l}\text { Ética da Saúde Pública: Responsabilidade Ético-legal na Administração dos Serviços } \\
\text { de Saúde; Bioética e Saúde Pública. }\end{array}$ \\
\hline Prof. Ka & $\begin{array}{l}\text { Vigilância de Alimentos: Substâncias Deletérias à Saúde e Alimentação - Vigilância de } \\
\text { Zoonoses: Riscos e Conseqüências de Contato com Animais. }\end{array}$ \\
\hline Prof. La & $\begin{array}{l}\text { Educação em Saúde Bucal em Escolares de Primeiro Grau - Saúde Bucal em Idosos: } \\
\text { Aspectos Epidemiológicos e Necessidades de Atenção - Organização de Serviços de } \\
\text { Saúde Bucal. Análise Institucional - Aplicação de Métodos Preventivos em Saúde } \\
\text { Bucal - Aspectos Comparativos. }\end{array}$ \\
\hline Prof. Ma & $\begin{array}{l}\text { Políticas Sociais em Saúde: Movimentos Sociais, Controle Social e Participação } \\
\text { Popular. Novas Formas de Sociabilidade: Violência e Saúde, Formas Emergentes de } \\
\text { Sociabilidade. }\end{array}$ \\
\hline Prof. $\mathrm{Na}$ & $\begin{array}{l}\text { A Responsabilidade em Direito Sanitário - Informação em Direito Sanitário; Tratamento } \\
\text { e Intercâmbio da Legislação Sanitária Brasileira nos três níveis de governo - } \\
\text { Harmonização da legislação sanitária no Mercosul - Eficácia do Direito à Saúde: A } \\
\text { Advocacia em Saúde no Brasil. }\end{array}$ \\
\hline Prof. Oa & $\begin{array}{l}\text { Organização de Serviços - Planejamento Estratégico de Recursos Humanos - } \\
\text { Gerenciamento Institucional. }\end{array}$ \\
\hline Prof. Pa & Prevenção em Saúde Pública. \\
\hline Prof. Qa & $\begin{array}{l}\text { Saúde no Trabalho: Promoção e Educação em Saúde (Fatores de Risco) - Saúde no } \\
\text { Trabalho: Educação para a Ergonomia - Qualidade de vida dos aposentados - } \\
\text { Comunidade afro-luso-brasileira, Necessidades de Treinamento Profissional. }\end{array}$ \\
\hline
\end{tabular}

Fonte: Seção de Pós-Graduação FSP/USP. 


\section{LINHAS DE PESQUISA POR ORIENTADOR DO DEPARTAMENTO DE NUTRIÇÃO}

\section{INFORMAÇÕES PARA INSCRIÇÃO DE CANDIDATOS AO CURSO DE PÓS- GRADUAÇÃO EMM SAÚDE PÚBLICA - 1998.}

\begin{tabular}{|c|c|}
\hline DOCENTES & LINHAS DE PESQUISA \\
\hline Prof. A & 1,2 e 3 \\
\hline Prof. B & 4 e 5 \\
\hline Prof C & 2 e 3 \\
\hline Prof. D & 2 \\
\hline Prof. E & 1 \\
\hline Prof. F & 1,2 e 3 \\
\hline Prof. G & 1,2, e 5 \\
\hline Prof $\mathrm{H}$ & 1,2, e 3 \\
\hline Prof I & 1 e 2 \\
\hline Prof J & 4 e 5 \\
\hline Prof L & $1 \mathrm{e} 2$ \\
\hline Prof M & 1 e 3 \\
\hline
\end{tabular}

\section{LINHAS DE PESQUISA}

Linha 1 - "Técnicas e métodos diagnósticos na avaliação nutricional e alimentar de populações" - Objetiva o desenvolvimento/adaptação/avaliação de técnicas, instrumentos, e métodos voltados para o diagnóstico do estado nutricional e do consumo alimentar de populações.

Linha 2 - "Freqüência, distribuição, determinantes e conseqüências de distúrbios nutricionais na população brasileira" - A partir de estudos de base populacional objetiva: 1) estimar a magnitude e a distribuição dos principais distúrbios nutricionais existentes no país (desnutrição protéico-energética, anemia ferropriva, hipovitaminose $A$, obesidade e dislipidemias, entre outros); 2) esatabelecer os fatores e mecanismos subjacentes à causalidade destes distúrbios; 3) determinar o impacto destes distúrbios sobre os indivíduos e a sociedade.

Linha 3 - "Formulação e avaliação de intervenções nutricionais" - Objetiva a formulação e avaliação de intervenções nutricionais ajustadas ao diagnóstico epidemiológico (magnitude, distribuição e causalidade) dos principais distúrbios nutricionais presentes no país, bem como a avaliação de efetividade e impacto de programas institucionais.

Linha 4 - "Criação e caracterização da estrutura dos alimentos" - Tem como objetivo a compreensão da relação estrutura molecular/funcionalidade em alimentos. Visa a obtenção de alimentos a partir de matérias primas novas ou convencionais que tenham estrutura final de alta aceitabilidade pelo consumidor.

Linha 5 - "Composição, processamento, valor nutritivo e higiene dos alimentos" Objetiva caracteriza química, física, biológica e sensorialmente, alimentos e preparações de alimentos em seus macro e micro constituintes, bem como as transformações e interações ocorridas no seu processamento, distribuição e consumo, de modo a identificar o valor nutritivo e o nível de segurança no consumo dos mesmos. 
Anexo 2

Cursos de Extensão Universitária FSP/USP 
Anexo 2 - Cursos de Extensão Universitária e Especialização (curta duração/USP) oferecidos pela FSP/USP, 1990 a 1997.

\begin{tabular}{|c|c|c|c|c|c|c|c|c|}
\hline Norredocurso & 1990 & 1991 & 1992 & 1993 & 1994 & 1995 & 1996 & 1997 \\
\hline A Epidemiologia e a Administração de Serv de Saúde & & & $\operatorname{sim}$ & & & & & \\
\hline A Sociologia e o Meio Ambiente & & & & & $\operatorname{sim}$ & & & \\
\hline Administração de Enfermagem em Serviços Locais de Saúde & & & & & $\operatorname{sim}$ & & & \\
\hline Administração de Projetos de Saúde & & $\operatorname{sim}$ & & & & & & \\
\hline Administração de Situações de Emergência e Desastres & & $\operatorname{sim}$ & & & & & & \\
\hline Análise de Regressão Multivariada & & & & & $\operatorname{sim}$ & $\operatorname{sim}$ & $\operatorname{sim}$ & $\operatorname{sim}$ \\
\hline Análise de Sobrevivência & & & & & & sim & $\operatorname{sim}$ & $\operatorname{sim}$ \\
\hline Análise Multivariada de Dados Categóricos & & & & $\operatorname{sim}$ & & & & \\
\hline Análise Multivariada de Sobrevivência com Variável dependente do Tempo & & & & & & $\operatorname{sim}$ & & \\
\hline Análise Multivariada Paramétricas de Sobrevivência & & & & & & $\operatorname{sim}$ & & \\
\hline Aspectos Bioecológicos dos Insetos Vetores de Endemias & & & & & & & & $\operatorname{sim}$ \\
\hline Aspectos Institucionais de Política e Gestão Ambiental & & $\operatorname{sim}$ & & & & & & \\
\hline Assistência de Enfermagem em S Pública na Área da Saúde da Mulher, da Criança e do Adolescente & & & & & $\operatorname{sim}$ & & & \\
\hline Assistência de Enfermagem S Pública na Área de Saúde do Adulto & & & & $\operatorname{sim}$ & & & & \\
\hline Assistência de Enfermagem S Pública no Controle das Doenças Transmissíveis & & & & $\operatorname{sim}$ & & & & \\
\hline Avaliação de Serviços de Saúde Materno-Infantil & & $\operatorname{sim}$ & & & & & & \\
\hline Avaliação e Gerenciamento de Riscos Ambientais & & & & $\operatorname{sim}$ & & & & \\
\hline Avaliação Sensorial de Alimentos & & & & & $\operatorname{sim}$ & & & \\
\hline Biologia de Aedes Aegypti e Medidas de Infestação Urbana & & & & & & & & $\operatorname{sim}$ \\
\hline Biologia e Ecologia de Aedes aegypti e Aedes albopictus & & & & & & & $\operatorname{sim}$ & \\
\hline Biologia e Identificação de Culicideos de Importância em S Pública & $\operatorname{sim}$ & $\operatorname{sim}$ & $\operatorname{sim}$ & $\operatorname{sim}$ & $\operatorname{sim}$ & $\operatorname{sim}$ & & $\operatorname{sim}$ \\
\hline Capacitação de Multiplicadores Docente-Assistenciais em Saúde Integral do Adolescente & $\operatorname{sim}$ & $\operatorname{sim}$ & $\operatorname{sim}$ & $\operatorname{sim}$ & & & & \\
\hline Capacitação em Gerência de Serviços de Saúde Materno-Infantil (internacional) & $\operatorname{sim}$ & $\operatorname{sim}$ & & & & & & \\
\hline Causas Múltiplas de Morte & & & & & & & & $\operatorname{sim}$ \\
\hline
\end{tabular}




\begin{tabular}{|c|c|c|c|c|c|c|c|c|}
\hline NomedoCurso & 1990 & 1991 & 1992 & 1993 & 1994 & 1995 & 1996 & 1997 \\
\hline * Classificação de Doenças & sim & & $\operatorname{sim}$ & & & & & \\
\hline Classificação e Codificação de Neoplasias & & $\operatorname{sim}$ & & & & & & \\
\hline Colheita de Mat. Biológico visando o Diagnóstico Laboratorial de Doenças causadas por Micobactérias & & & & $\operatorname{sim}(3 x)$ & $\operatorname{sim}(2 \mathrm{x})$ & & & \\
\hline Componente Educativo dos Programas de S Pública & & $\operatorname{sim}$ & $\operatorname{sim}$ & & & & & \\
\hline Consumo de Drogas e HIV: Uma Contribuição Antropológica para a Redução dos Danos à Saúde & & & & & & $\operatorname{sim}$ & & \\
\hline * Controle Ambiental & & & & & $\operatorname{sim}$ & $\operatorname{sim}$ & $\operatorname{sim}$ & \\
\hline Controle de Infecção Hospitalar e Desenvolvimento de Qualidade & & & & & & $\operatorname{sim}$ & & \\
\hline $\begin{array}{l}\text { Crianças e Adolescentes como Vítimas de Agressão Física e Sexual no Lar: Aspectos Conceituais e } \\
\text { Conseqüências para a S Pública }\end{array}$ & $\operatorname{sim}$ & & & & & & & \\
\hline Cuidar do Idoso, Cuidar de Si Mesmo & & & & & & & $\operatorname{sim}$ & \\
\hline Curso Ítalo Brasileiro de Atualização em Higiene e Toxicologia Ocupacional - Benzeno, Chumbo e Mercúrio & & & & & & $\operatorname{sim}$ & & \\
\hline Delineamento de Estudos Epidemiológicos & & & & & & & & $\operatorname{sim}$ \\
\hline Desenho, Análise de Estudos Ecológicos em Epidemiologia & & & $\operatorname{sim}$ & & & & & \\
\hline Desenhos de Estudos em Epidemiologia & & & & & & & $\operatorname{sim}$ & \\
\hline Diabetes Mellitus - Enfoque Multidisciplinar no Atendimento de Pacientes Diabéticos & & & & & & $\operatorname{sim}$ & & \\
\hline Direito Sanitário (aperfeiçoamento) & & & & & & & & $\operatorname{sim}$ \\
\hline * Direito Sanitário (especialização) & & $\operatorname{sim}$ & & $\operatorname{sim}$ & & & & \\
\hline Doenças Sexualmente Transmissíveis & $\operatorname{sim}$ & $\operatorname{sim}$ & $\operatorname{sim}$ & $\operatorname{sim}$ & $\operatorname{sim}$ & $\operatorname{sim}$ & $\operatorname{sim}$ & $\operatorname{sim}$ \\
\hline * Educação Ambiental & & & & & $\operatorname{sim}$ & & $\operatorname{sim}$ & $\operatorname{sim}$ \\
\hline * Engenharia Ambiental & $\operatorname{sim}$ & & & & & & & \\
\hline * Engenharia de Controle de Poluição Ambiental & & & & $\operatorname{sim}$ & & & $\operatorname{sim}$ & $\operatorname{sim}$ \\
\hline * Engenharia de Saneamento Básico & & & $\operatorname{sim}$ & $\operatorname{sim}$ & $\operatorname{sim}$ & & $\begin{array}{l}\text { sim } \\
(2 x)\end{array}$ & $\operatorname{sim}(2 x)$ \\
\hline * Engenharia em S Pública & $\operatorname{sim}$ & & & & & & & \\
\hline Entomologia Médica & & & & & $\operatorname{sim}$ & $\operatorname{sim}$ & $\operatorname{sim}$ & $\operatorname{sim}$ \\
\hline Envelhecer com Qualidade de Vida & & & & $\operatorname{sim}$ & & & & \\
\hline
\end{tabular}




\begin{tabular}{|c|c|c|c|c|c|c|c|c|}
\hline NorredoCurso & 1990 & 1991 & 1992 & 1993 & 1994 & 1995 & 1996 & 1997 \\
\hline Envelhecimento e Trabalho & & & & & & $\operatorname{sim}$ & & \\
\hline EPI INFO Avançado & & & & & $\operatorname{sim}$ & $\operatorname{sim}$ & & \\
\hline EPI INFO: Curso Básico & & & $\operatorname{sim}(2 x)$ & & & & & \\
\hline Epidemiologia Clínica & & & $\operatorname{sim}$ & & $\operatorname{sim}$ & & & \\
\hline Epidemiologia das Doenças Cardiovasculares & & & & & $\operatorname{sim}$ & $\operatorname{sim}$ & & $\operatorname{sim}$ \\
\hline Epidemiologia das Doenças Transmissíveis & & & $\operatorname{sim}$ & & $\operatorname{sim}$ & $\operatorname{sim}$ & $\operatorname{sim}$ & $\operatorname{sim}$ \\
\hline Epidemiologia do Câncer & & & & & & & $\operatorname{sim}$ & $\operatorname{sim}$ \\
\hline Epidemiologia no Processo Saúde-Trabalho & & & & & $\operatorname{sim}$ & & & \\
\hline Estatísticas de S Pública para Nível Médio & & $\operatorname{sim}$ & $\operatorname{sim}$ & & & & & \\
\hline Estatísticas de Saúde & & $\operatorname{sim}$ & & $\operatorname{sim}$ & & & & \\
\hline Estudos de Impacto Ambiental e Relatórios de Imp. sobre Meio Ambiente (IA/RIMA) & & & & $\operatorname{sim}$ & & & & \\
\hline Formação de Coordenadores para Prevenção de Acidentes do Trabalho & $\operatorname{sim}(2 \mathrm{x})$ & & & & & & & \\
\hline Formação de Instrutores de Treinamento para o SUS & & & & $\operatorname{sim}$ & & & & \\
\hline Formação de Multiplicadores no Uso da 10ª Revisão da Classificação Internacional de Doenças em Mortalidade & & & & & $\operatorname{sim}$ & $\operatorname{sim}$ & & \\
\hline Gerência de Qualidade em Saúde - o Horizonte da Gestão de Qualidade e o Hospital & & & $\operatorname{sim}$ & & & & & \\
\hline Gerência de Recursos Humanos para o SUS & & & & $\operatorname{sim}$ & & & & \\
\hline Gerência de Sistemas Locais/Regionais de Saúde SUDS/Pará & $\operatorname{sim}$ & & & & & & & \\
\hline Gerenciamento de Projetos de Desenvolvimento Social & & & & & & & $\operatorname{sim}$ & \\
\hline Gestão Ambiental & & & & & & $\operatorname{sim}(2 x) s$ & $\operatorname{sim}(2 x)$ & $\operatorname{sim}$ \\
\hline Gestão de Serviços de Saúde & & & & & & & & $\operatorname{sim}$ \\
\hline Hipertensão Arterial: enfoque multidisciplinar no atend. de pacientes hipertensos & & & & $\operatorname{sim}$ & $\operatorname{sim}$ & $\operatorname{sim}$ & & \\
\hline Importância dos Insetos na S Pública & & & $\operatorname{sim}$ & & & & & \\
\hline Infectious Disease Epidemiology (Epidemiologia Doenças Infecciosas) & & & $\operatorname{sim}$ & & & & & \\
\hline Informação em Saúde: Família de Classificações & & & & & & & $\operatorname{sim}$ & \\
\hline Informações e Microinformática em Saúde & $\operatorname{sim}$ & & & & & & & \\
\hline
\end{tabular}

Continua 


\begin{tabular}{|c|c|c|c|c|c|c|c|c|}
\hline Noredocarso & 1990 & 1991 & 1992 & 1993 & 1994 & 1995 & 1996 & 1997 \\
\hline Informações em Saúde: Nomenclatura e Classificação de Doenças - A Família de Classificações & & & & & & & & $\operatorname{sim}$ \\
\hline International Environmental Management System Standards & & & & & & & & sim \\
\hline Introdução à Bioestatística & & & & & & sim & sim & sim \\
\hline Introdução ao Direito Sanitário (atualização) & & & & & & sim & $\operatorname{sim}$ & sim \\
\hline Introdução as Técnicas Neo-Xamânicas de Auto-Cuidado & & & $\operatorname{sim}$ & & & & & \\
\hline Investigação de Campo na Pesquisa Epidemiológica & & & & & $\operatorname{sim}$ & & & \\
\hline Investigação Epidemiológica em Doenças Emergentes & & & & & & & & $\operatorname{sim}$ \\
\hline Logistic Regression Methodis for Epidemiologic Analysis (Met. Regr. Log. Anal Epid.) & & & sim & & & & & \\
\hline Macrovisão da S Pública no Brasil & & & & & & sim & & \\
\hline Metodologia de Pesquisa em AIDS & & & & & & & $\operatorname{sim}$ & $\operatorname{sim}$ \\
\hline Metodologia Epidemiológica & & & & sim & & & & \\
\hline Metodologia Epidemiológica - Unidade II & sim & & & & & & & \\
\hline Metodologia Qualitativa: Instrumento de Investigação da Realidade da Criança em Idade Escolar & & & & & & & & $\operatorname{sim}$ \\
\hline Metodologias para Estudos de Consumo Alimentar & sim & & & & & & & \\
\hline Métodos Epidemiológicos no Estudo da Mortalidade Infantil & & & & & & & $\operatorname{sim}$ & $\operatorname{sim}$ \\
\hline Movimentos Sociais e Saúde & sim & & & & & & & \\
\hline \multicolumn{4}{|c|}{ Multiplicadores - Egressos dos Cursos de Capacitação em Saúde Integral do Adolescente (Maranhão/Piauí e Natal) } & & & sim & sim & \\
\hline Noções Básicas da Epidemiologia da AIDS & & & sim & & & & & \\
\hline Novas Tendências Teórico-práticas da Educação em Saúde & & & & & & sim & & \\
\hline Nutrição na Terceira Idade & & & & sim & & & & \\
\hline Pesquisa Social em S Pública & & $\operatorname{sim}$ & & & & & & \\
\hline Planejamento do Setor Saúde & & & & & sim & sim & & \\
\hline Planejamento em Promoção e Educação em Saúde & & & & & sim & & & \\
\hline Planejamento em Saúde Materno-Infantil: O Acesso a Saúde & & sim & & & & & & \\
\hline Políticas de Meio Ambiente: Viabilidade de Implantação & & & & sim & & & & \\
\hline
\end{tabular}




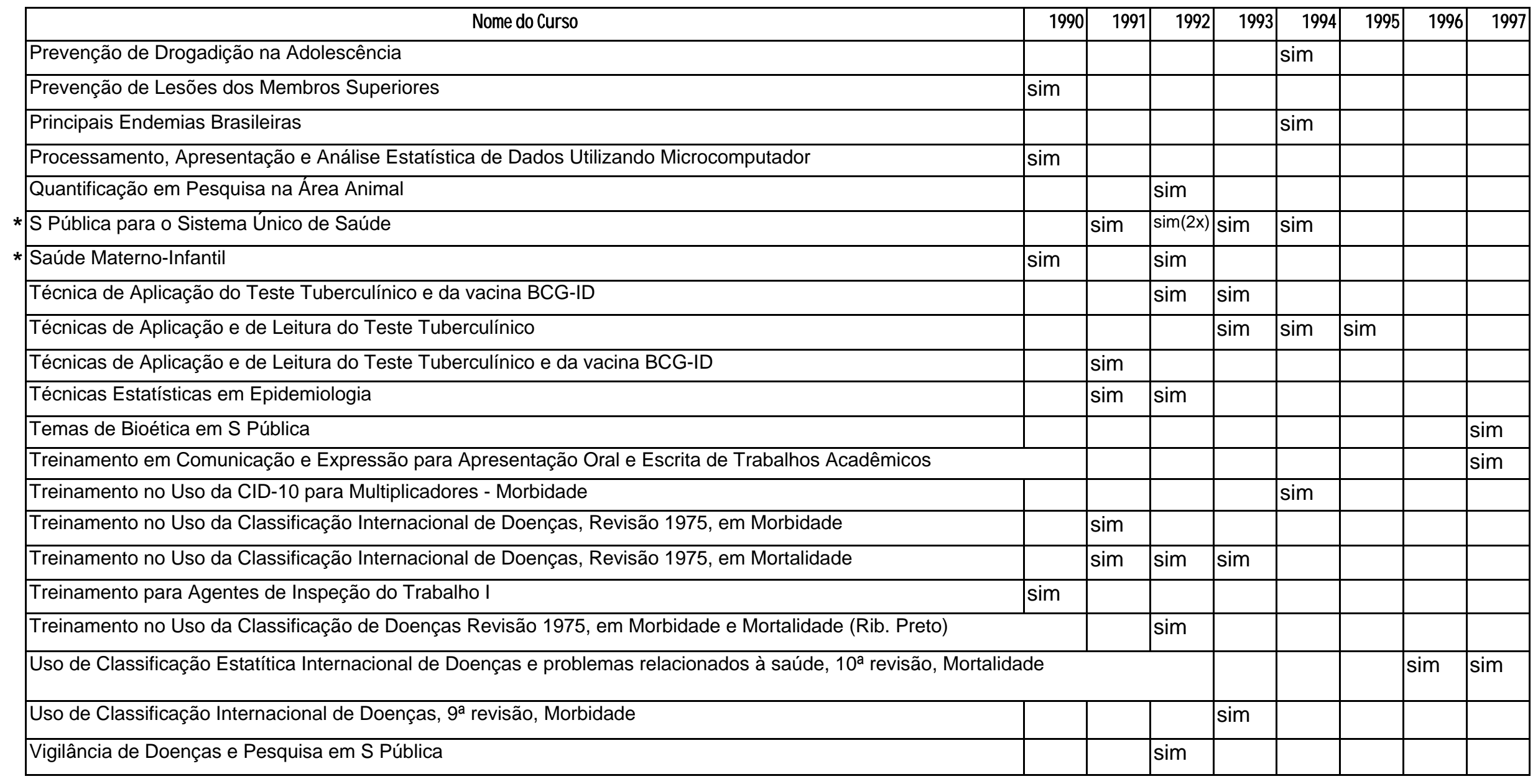

Fonte: Seção de Alunos FSP/USP

- Cursos de especialização Sensu Lato (entre 360 e 720 horas) 
Anexos 3 e 4

Roteiros de entrevista 


\section{ROTEIRO DE ENTREVISTA COM ALUNOS}

- Caminho de chegada - Como você se aproximou da pós graduação da FSP

$\Rightarrow$ por que pós graduação?

$\Rightarrow$ por que em saúde pública?

$\Rightarrow$ por que na FSP?

$\Rightarrow$ como obteve informações sobre o curso?

$\Rightarrow$ expectativas e aspirações

$\Rightarrow$ processo seletivo: como foram as provas e a escolha da área de concentração e do orientador

- Desenvolvimento do Curso

$\Rightarrow$ como se deu a montagem do programa de estudos: escolha das disciplinas.

$\Rightarrow$ como você considera o aproveitamento das disciplinas - obrigatórias e eletivas

$\Rightarrow$ quais as dificuldades e aspectos facilitadores do processo de orientação

$\Rightarrow$ como foi definido ou como está sendo definido o projeto de pesquisa

$\Rightarrow$ como está se dando sua inserção na FSP:

uso de recursos (bilblioteca, computador ...)

envolvimento em grupos de pesquisa

envolvimento com grupo de alunos

outros vínculos com a FSP

$\Rightarrow$ como foi se tornando aluno na FSP:

- Atividade profissional x Pós Graduação

$\Rightarrow$ foi liberado para fazer o curso?

$\Rightarrow$ caso não: dificuldades e formas de conciliar as duas atividades aspectos positivos de exercer as duas atividades 


\section{ROTEIRO DE ENTREVISTA COM PROFESSORES}

\section{* Como é para você ser professor na Pós na FSP?}

- Como foi se tornando professor da pós graduação na FSP

$\Rightarrow$ exercia outra atividade antes de trabalhar na FSP? Qual?

$\Rightarrow$ tem outra atividade profissional?

$\Rightarrow$ como iniciou seu trabalho no curso de pós graduação da FSP?

- Como você e seu Departamento selecionam o aluno - critérios e processo

- Como trabalha a elaboração do programa de estudos do aluno

$\Rightarrow$ discute junto com o aluno?

$\Rightarrow$ procura disciplinas fora da FSP?

- Como trabalha com o orientando durante o curso?

- Como cria suas disciplinas e linha de pesquisa?

- Que estratégias de ensino utiliza para ministrar as disciplinas

- Qual o seu relacionamento com órgãos colegiados na FSP e com CAPES? 
Anexo 5

Normas do Curso de Mestrado FSP/USP 
Síntese de alguns itens das Normas do Curso de Mestrado da FSP/USP, 1970 a 1998.

\begin{tabular}{|c|c|c|c|c|c|c|}
\hline Itens & 1970 & 1973 & 1981 & 1982 & 1983 & 1984 \\
\hline $\begin{array}{l}\text { Pré-requisitos para } \\
\text { inscrição }\end{array}$ & & $\begin{array}{c}\text { ter feito Curso de Saúde } \\
\text { Pública para Graduados na } \\
\text { FSP }^{*} \text { com média global maior } \\
\text { que } 7 \text {, e no máximo } 2 \text { disc } \\
\text { entre } 5 \text { e } 7 .\end{array}$ & idem & $\begin{array}{l}\text { Curso de Especialização em } \\
\text { Saúde Pública ou em } \\
\text { Administração Hospitalar, ou } \\
\text { Habilitação em Enfermagem } \\
\text { de Saúde Pública** }\end{array}$ & idem & idem \\
\hline Processo Seletivo & $\begin{array}{l}\text { Exame do currículo escolar, } \\
\text { verificação de aptidão para } \\
\text { estudos de pós-graduação por } \\
\text { entrevista ou prova de } \\
\text { capacidade }\end{array}$ & $\begin{array}{l}\text { Exame de inglês eliminatório, } \\
\text { verificação de aptidão }\end{array}$ & $\begin{array}{l}\text { Exame de inglês } \\
\text { eliminatório }\end{array}$ & $\begin{array}{c}\text { Prova de inglês eliminatória. } \\
\text { Exame de Habilitação: prova } \\
\text { geral (Adm Sanitária, } \\
\text { Epidemiologia, Saneamento } \\
\text { Geral, C. Sociais, Educação } \\
\text { em S Pública); e prova } \\
\text { específica. }\end{array}$ & idem & idem \\
\hline $\begin{array}{l}\text { Escolha do } \\
\text { orientador }\end{array}$ & $\begin{array}{l}\text { Orientador se compromete } \\
\text { diretamente com o candidato. }\end{array}$ & idem & idem & idem & idem & idem \\
\hline № de Vagas & não definido nas normas & $\begin{array}{c}20 \text { em 1975, } 25 \text { em 1976, e } \\
\text { após definida pelas áreas de } \\
\text { opção }\end{array}$ & $\begin{array}{c}35 \text { (4 AH, } 14 \text { SSP } \\
8 \text { EPI, } 4 \text { NUT, } 5 \\
\text { SA) }\end{array}$ & $\begin{array}{c}\text { de acordo } \mathrm{c} / \text { disponibilidade do } \\
\text { orientador }\end{array}$ & idem & idem \\
\hline \multirow[t]{2}{*}{ Créditos } & $\begin{array}{l}\text { 120, sendo } 60 \text { em aulas e } \\
\text { seminários, } 30 \text { em estágio e } \\
30 \text { dissertação }\end{array}$ & idem & idem & idem & idem & idem \\
\hline & & & & & $\begin{array}{l}\text { Dos } 60 \text {, no mínimo } 40 \\
\text { na área e destes no } \\
\text { mínimo } 20 \text { na opção }\end{array}$ & idem \\
\hline Disc obrigatórias & não existiam & idem & idem & idem & idem & idem \\
\hline Prazo total & sem referência & idem & idem & idem & idem & $\begin{array}{l}1 \text { a } 5 \\
\text { anos }\end{array}$ \\
\hline
\end{tabular}

"em 1974 alterado incluindo também os cursos de Administração Hospitalar e Educação em Saúde Pública

** Cursos realizados fora da FSP na dependência do julgamento da CPG 
Síntese de alguns itens das Normas do Curso de Mestrado da FSP/USP, 1970 a 1998.

\begin{tabular}{|c|c|c|c|c|c|c|c|}
\hline Itens & 1987 & 1991 & 1992 & 1993 & 1995 & 1997 & 1998 \\
\hline $\begin{array}{l}\text { Pré-requisitos para } \\
\text { inscrição }\end{array}$ & idem & $\begin{array}{l}\text { sem pré requisitos } \\
\text { específicos }\end{array}$ & idem & idem & idem & idem & idem \\
\hline Processo Seletivo & $\begin{array}{c}\text { Prova de inglês } \\
\text { eliminatória. Exame de } \\
\text { Habilitação: prova geral } \\
\text { (Adm Sanitária, } \\
\text { Epidemiologia, } \\
\text { Saneamento do Meio, C. } \\
\text { Sociais, Educação em S } \\
\text { Pública, Bioestatística, } \\
\text { Estatística Vital); e prova } \\
\text { específica. }\end{array}$ & $\begin{array}{c}\text { Prova de inglês eliminatória. } \\
\text { Prova escrita para avaliar a } \\
\text { capacidade de } \\
\text { interpretação, síntese, } \\
\text { expressão e análise de } \\
\text { texto. }\end{array}$ & idem & idem & idem & idem & idem \\
\hline $\begin{array}{l}\text { Escolha do } \\
\text { orientador }\end{array}$ & idem & seleção nos departamentos & idem & idem & idem & idem & idem \\
\hline № de Vagas & idem & $\begin{array}{c}\text { no passa a ser fixado } \\
\text { anualmente (em torno de } \\
70)\end{array}$ & idem & idem & idem & $\begin{array}{l}\text { de acordo } \mathrm{c} / \\
\text { disponibilidade de } \\
\text { orientador }\end{array}$ & idem \\
\hline \multirow[t]{2}{*}{ Créditos } & idem & $\begin{array}{l}120 \text { créd sendo } 90 \text { em } \\
\text { disciplinas e } 30 \text { a } \\
\text { dissertação }\end{array}$ & idem & $\begin{array}{l}120 \text { créd sendo } 80 \text { em } \\
\text { disciplinas e } 40 \mathrm{a} \\
\text { dissertação }\end{array}$ & $\begin{array}{l}120 \text { créditos sendo } \\
60 \text { em disciplinas e } \\
60 \text { dissertação }\end{array}$ & $\begin{array}{l}96 \text { sendo } 48 \text { em } \\
\text { disciplinas e } 48 \text { a } \\
\text { dissertação }\end{array}$ & idem \\
\hline & $\begin{array}{c}\text { Dos } 60, \text { no minimo } 40 \text { na } \\
\text { área e destes no minimo } \\
20 \text { na opção. Até } 1 / 3 \text { pode } \\
\text { ser fora da USP }\end{array}$ & $\begin{array}{c}\text { Até } 1 / 3 \text { dos créd em } \\
\text { disciplinas pode ser fora da } \\
\text { USP }\end{array}$ & idem & idem & idem & idem & idem \\
\hline Disc obrigatórias & idem & $\begin{array}{l}62 \text { créd - S. Sociedade, } \\
\text { Epidemiologia, Adm de } \\
\text { Serviços de Saúde } \\
\text { Bioestatística, Metodologia } \\
\text { de Pesquisa, Meio } \\
\text { Ambiente e Saúde, Didática }\end{array}$ & $\begin{array}{c}37 \text { créd - S. } \\
\text { Sociedade, } \\
\text { Epidemiologia, Adm } \\
\text { de Serviços de Saúde } \\
\text { Bioestatística, } \\
\text { Metodologia de } \\
\text { Pesquisa, Didática }\end{array}$ & $\begin{array}{c}44 \text { ou } 40 \text { créd - S. } \\
\text { Sociedade, Epidemiologia, } \\
\text { Adm de Serviços de } \\
\text { Saúde Bioestatística, } \\
\text { Metodologia de Pesquisa, } \\
\text { Meio Ambiente, Didática, } \\
\text { Nutrição }\end{array}$ & $\begin{array}{c}38 \text { créd - S. } \\
\text { Sociedade, } \\
\text { Epidemiologia, } \\
\text { Adm de Serviços } \\
\text { de Saúde } \\
\text { Bioestatística, } \\
\text { Metodologia de } \\
\text { Pesquisa, Didática. }\end{array}$ & $\begin{array}{c}21 \text { créd - S. } \\
\text { Sociedade, } \\
\text { Epidemiologia, } \\
\text { Adm de Serviços } \\
\text { de Saúde } \\
\text { Bioestatística, } \\
\text { Metodologia de } \\
\text { Pesquisa }\end{array}$ & $\begin{array}{c}21 \text { créd- S. } \\
\text { Sociedade, } \\
\text { Epidemiologia, } \\
\text { Adm de Serviços } \\
\text { de Saúde } \\
\text { Bioestatística, } \\
\text { Metodologia de } \\
\text { Pesquisa }\end{array}$ \\
\hline Prazo total & idem & idem & idem & idem & idem & 1 a 3 anos & 1 a 3 anos \\
\hline
\end{tabular}

Fonte: Seção de Alunos FSP/USP 


\section{Anexo 6}

\section{Pós-Graduação Stricto Sensu FSP/USP}

Disciplinas eletivas oferecidas segundo departamento e período de aula, 1990, 1994 e 1998 

Disciplinas Eletivas Oferecidas

Pós-Graduação Stricto Sensu da FSPJUSP segundo Departamento e Periodo de aula - 1990

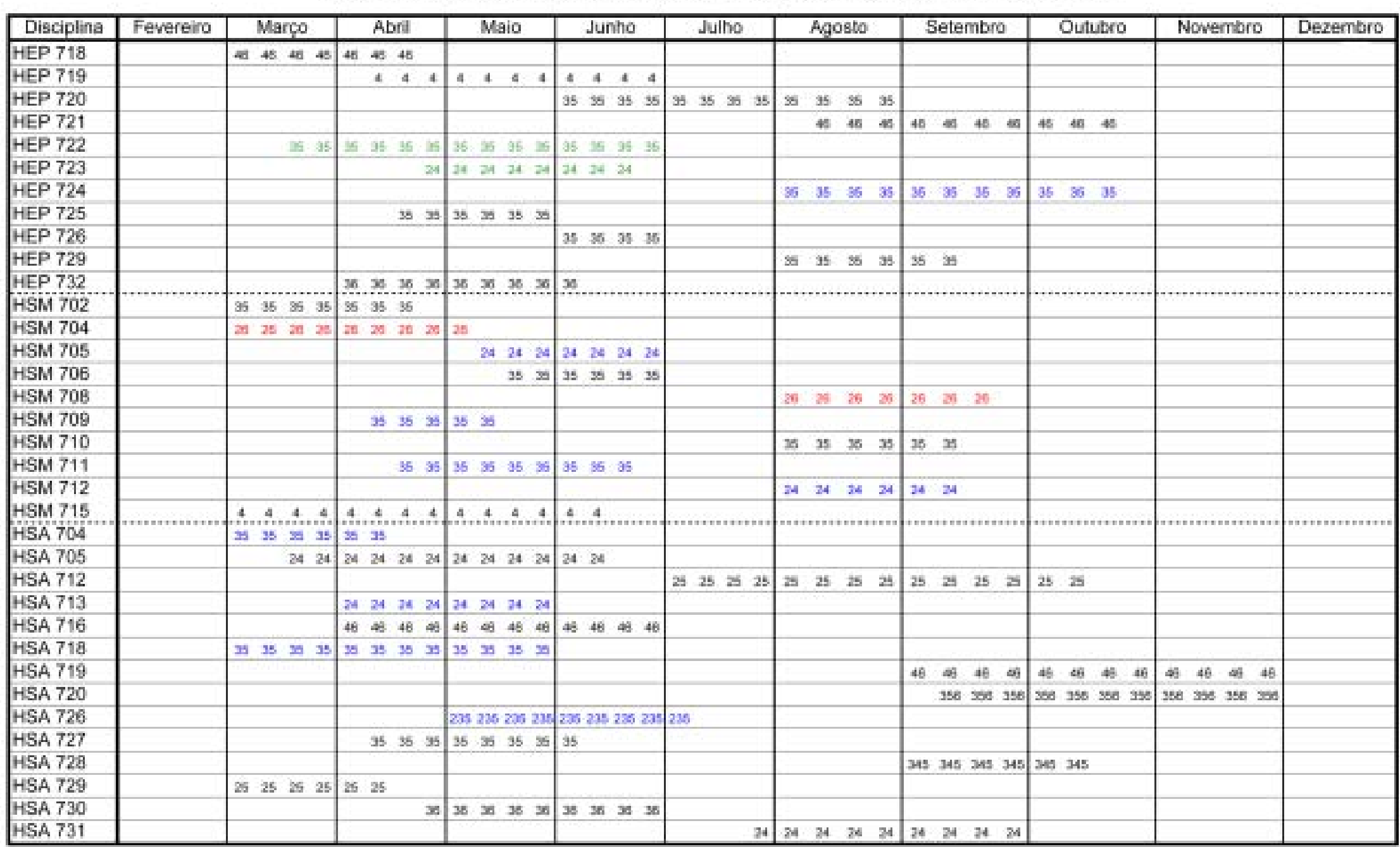

In:MARTINS CL, 1990

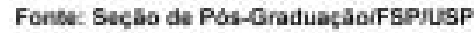


Disciplinas Elotivas Oferecidas

Pós-Graduaçīo Stricto Sensu da FSP/USP segundo Departamento e Periodo de aula = 1990

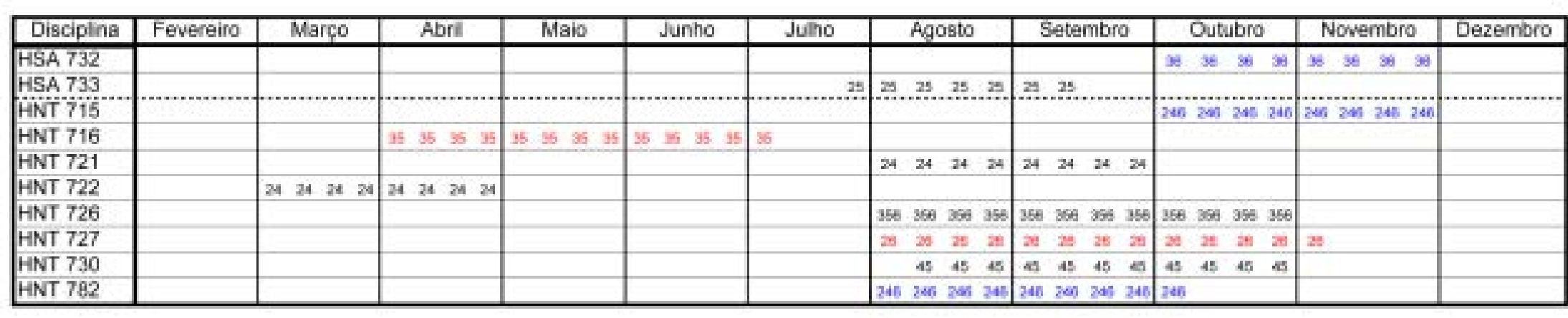

Legenda: ausas no periodo da manta

auias mo perindo da manta e da tarte

aulas no periodo da tarde

Cs nùmeros indeam as das da sempana, por ex

$2-\operatorname{sins}$ as $2^{\circ}$ ferras

avias no periodo das 17 as $20 \mathrm{~h}$

3 - adss as $3^{*}$ Feras

aikas unta ver por semasa marha o terde

e as cutros veres oo menhs

24- eulas as $2^{2}$ e 4 forias

35 - sulas as $3^{*}$ e 5 teriras

240 - audas $252^{\circ}, 4^{*}$ e 60 feras

aulas uma wez por semasa marha e o:tra vez nome

2 a 6 - aulas de $2^{\circ}$ a $6^{\circ}$ seira 
Disciplinas Eletivas Oferecidas

Pós-Graduaçáo Stricto Sensu da FSPJUSP segundo Departamento e Periodo de aula - 1994

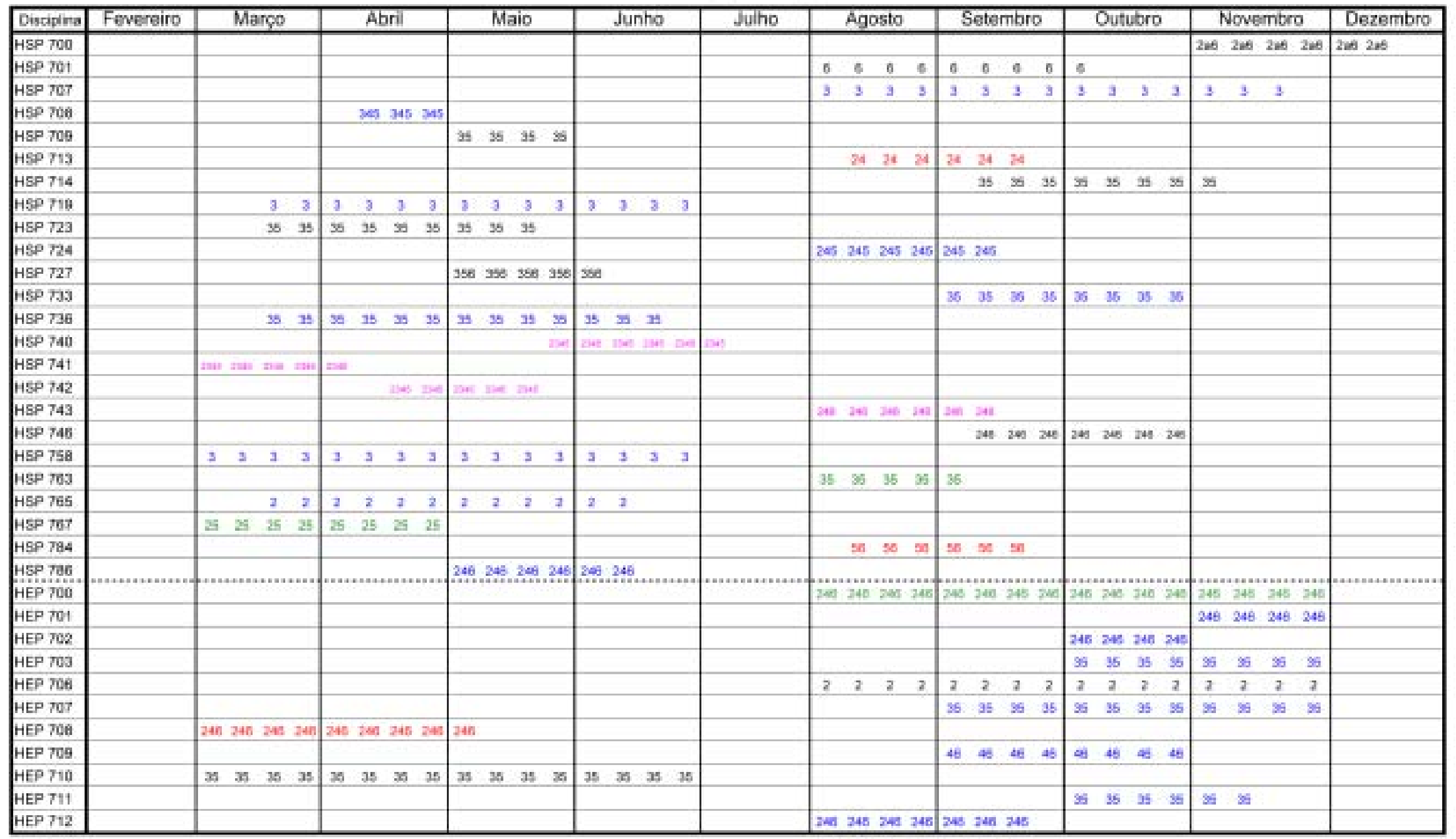


Disciplinas Eletivas Oferecidas

Pós-Graduaçăo Stricto Sensu da FSP/USP segundo Departamento e Periodo de aula - 1994

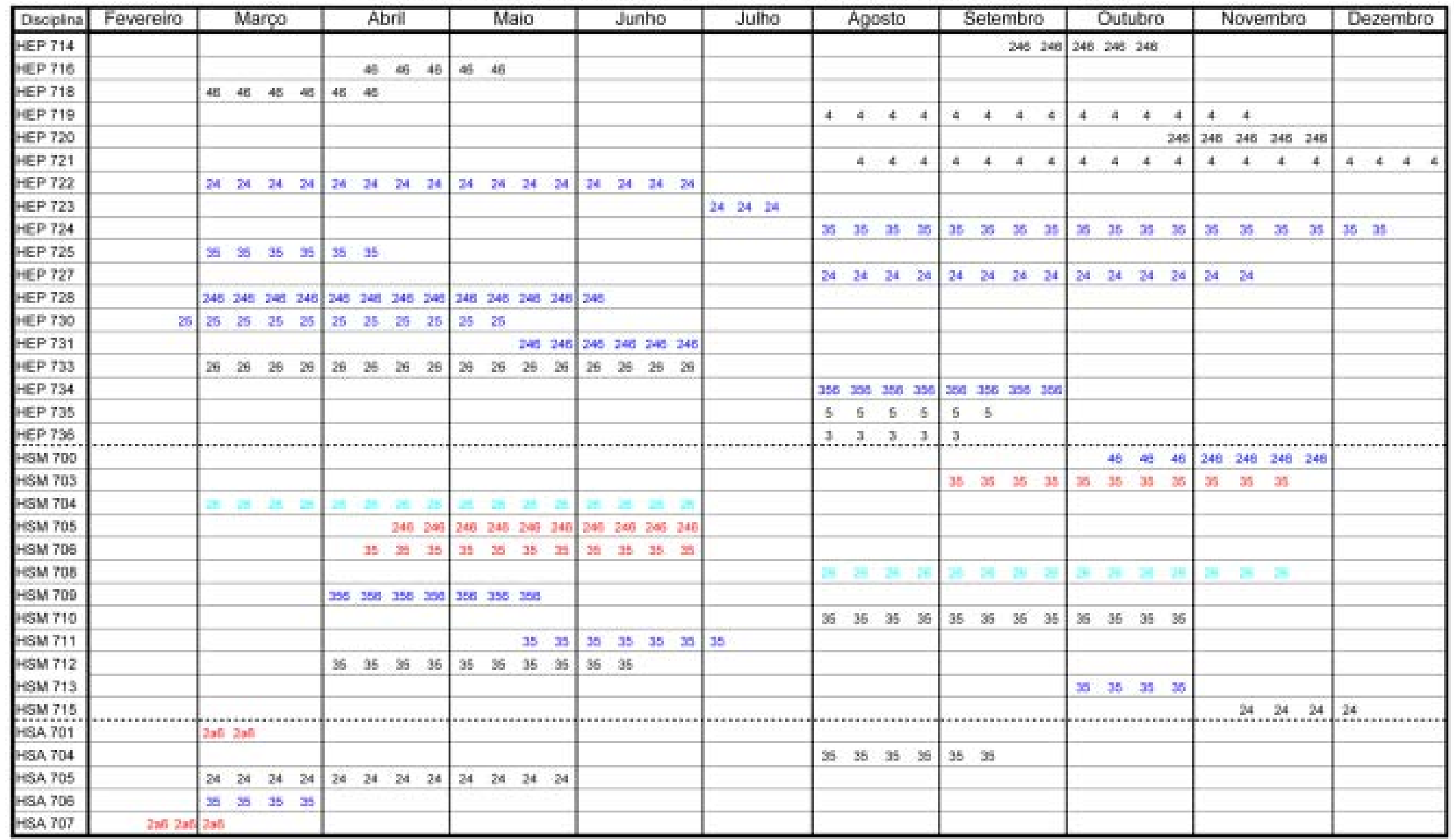


Disciplinas Eletivas Oferecidas

Pós-Graduaça Stricto Sensu da FSPIUSP segundo Departamento e Periodo de aula - 1994

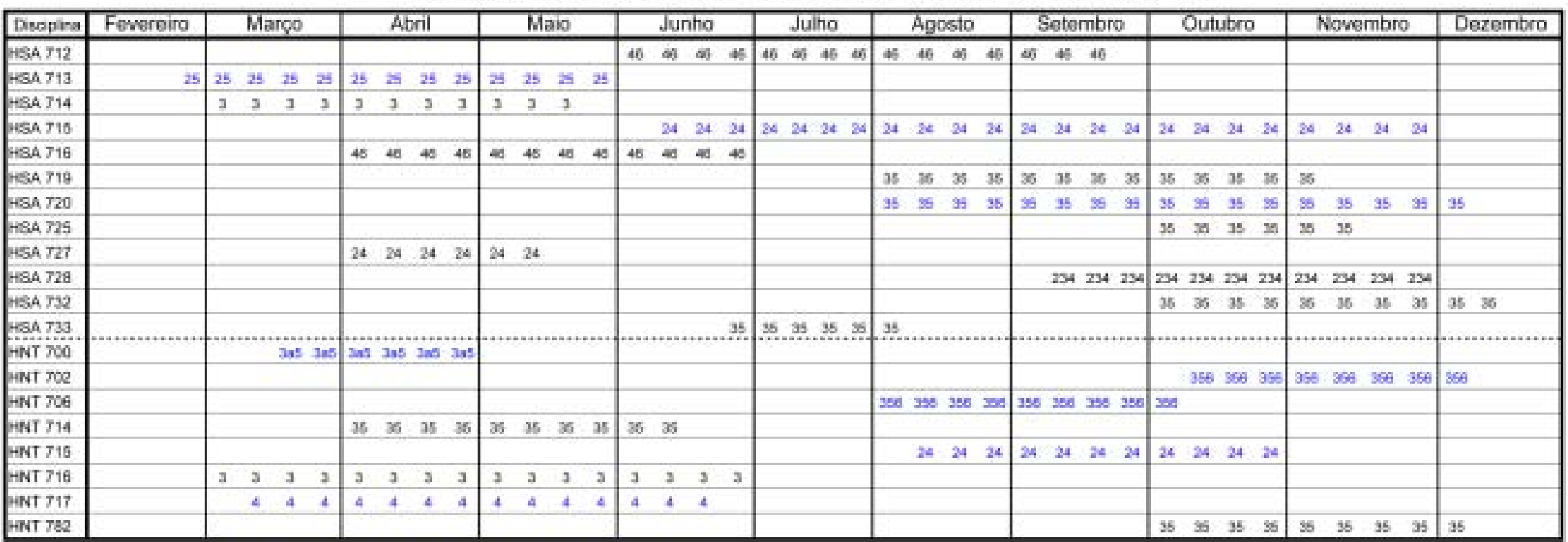

Legende

\section{aủas no periodo da manhá}

aulas no periodo da macha e tis tarde

aufas no periodo da tarde

aulas no periedo das 17 ats $20 \mathrm{~h}$

auss uma vez por Bemsna ma-has e tarch

e as outras vezes so marhs

aikas u=a vez per samana machá es ostra vaz noibe
Os nümeros indicam co diss da semana, por ex

2-aukas ka 20 leiria

3- aujas as $3^{*}$ Feiras

24- aulas as $2^{\circ}$ e 4 - fuiras

$35-a d s s$ is $x^{2}$ e 5 feiras

246 - aulas as $2^{n}, 4^{*}$ e $6^{\prime}$ ferias

2 a 6 - aunas de $2^{4}$ a $\theta^{\circ}$ larse 
Disciplinas Eletivas Oferecidas

Pós-Graduação Stricto Sensu da FSP/USP segundo Departamento e Periodo de aula - 1998

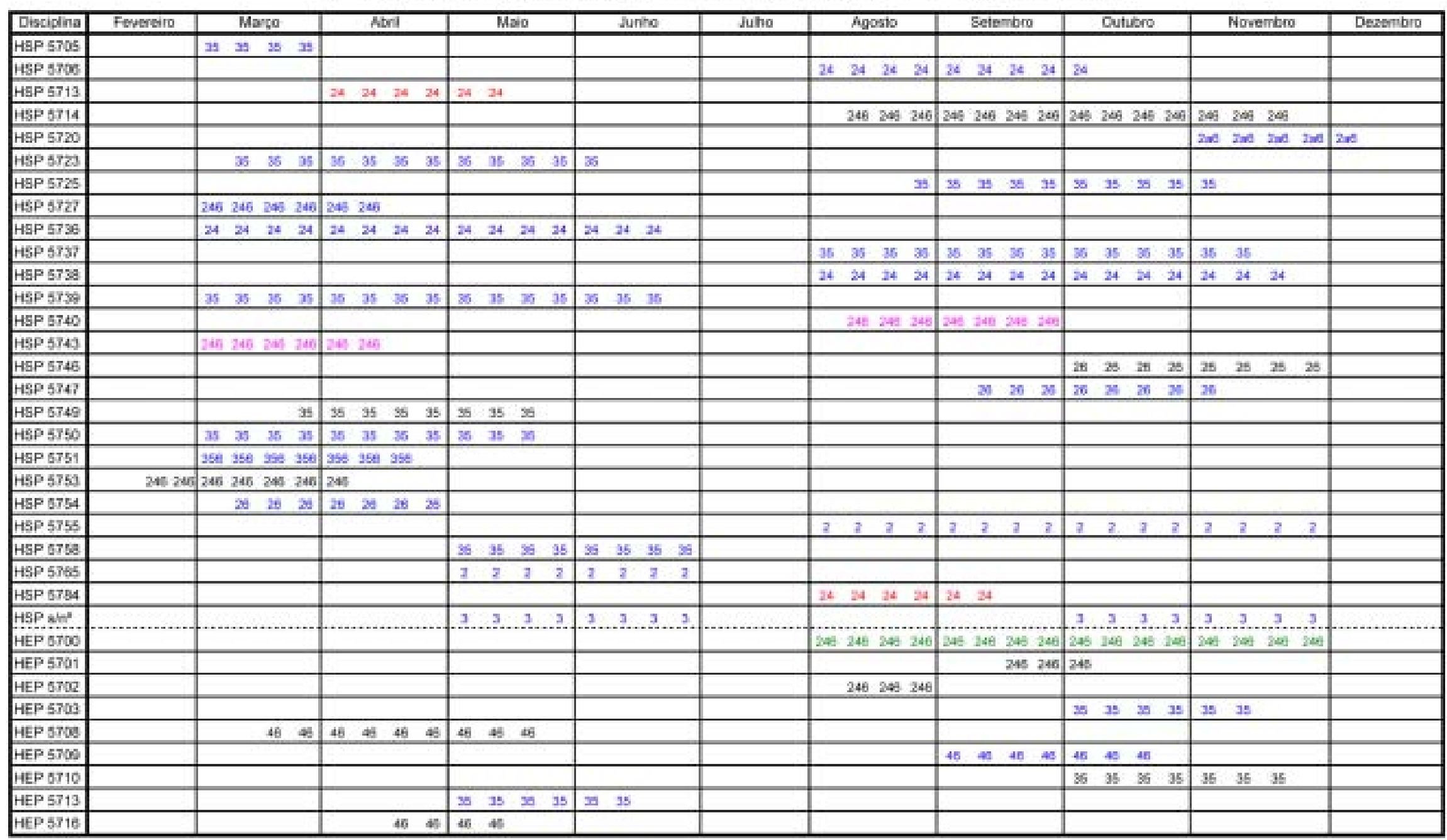

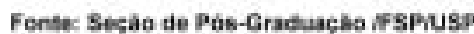


Disciplinas Eletivas Oferecidas

Pós-Graduaçào Stricto Sensu da FSP/USP segundo Departamento e Periodo de aula - 1998

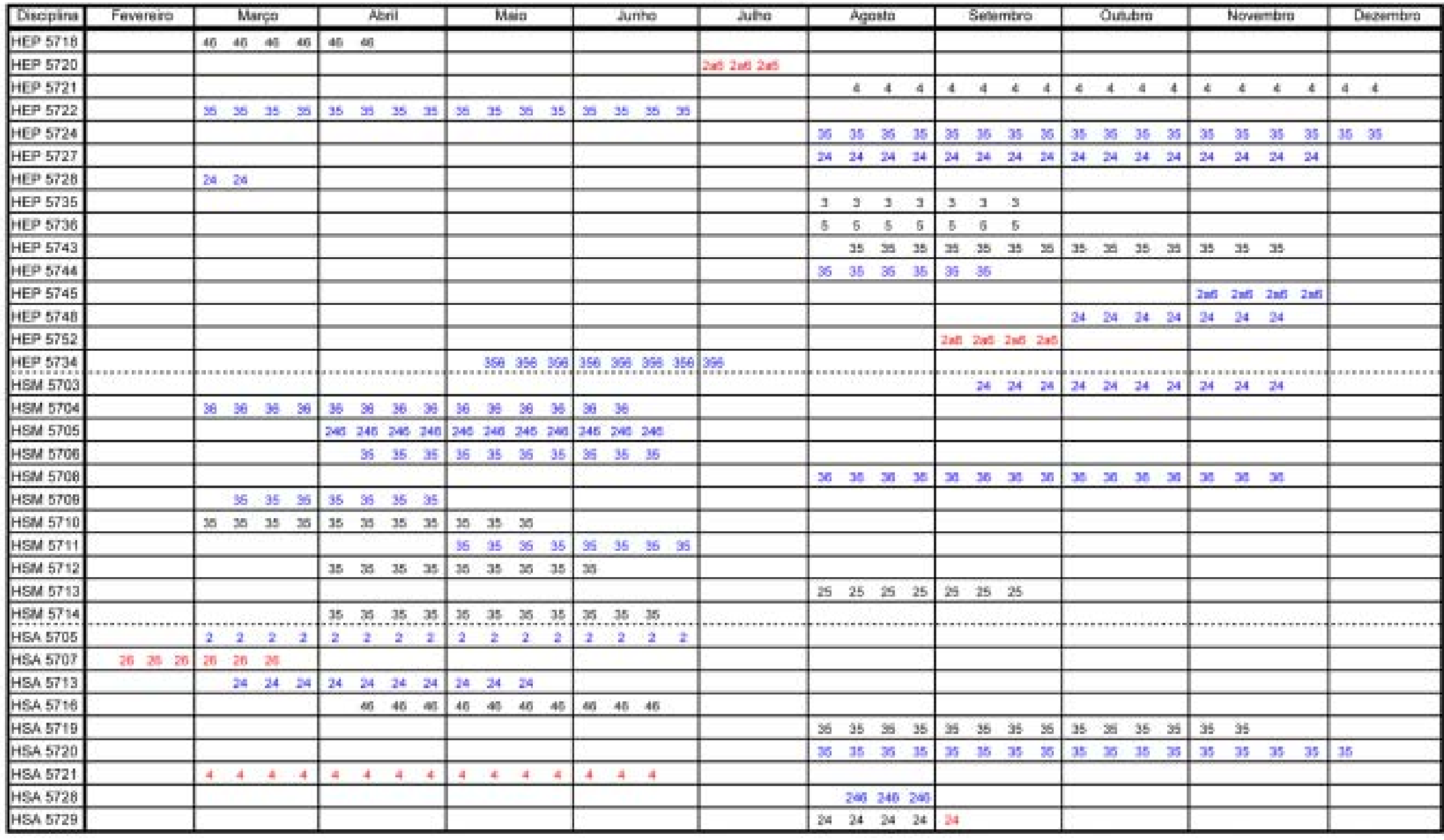

Fonte: Seçso de Pós-Graduaçlo ifsPiusp. 
Disciplinas Eletivas Oferecidas

Pós-Graduaçăo Stricto Sensu da FSPIUSP segundo Departamento e Periodo de aula - 1998

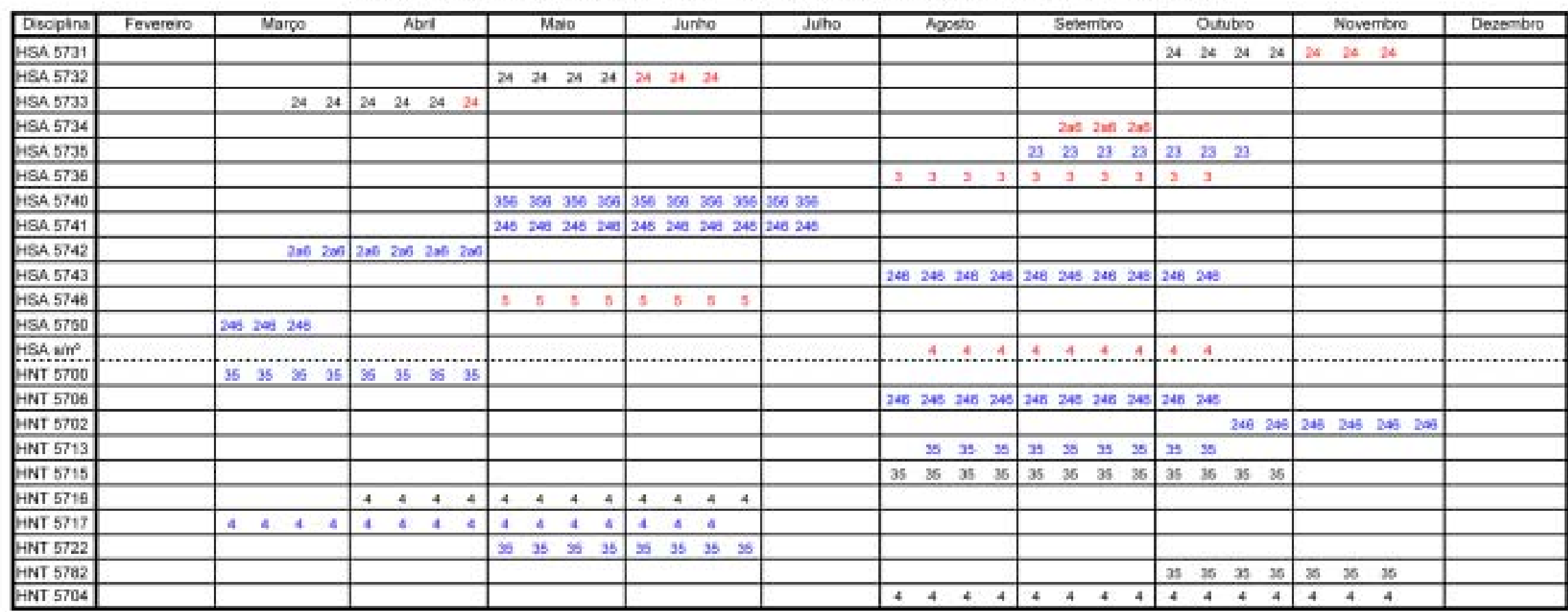

Logerda.

Wuas no veriodo da manad

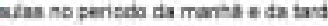

was no periodo da tando

visas no perivda das 17 in $20 \mathrm{~h}$

vias vma vez par senvana nanta e tarsh

e a sutras vacas so mama.

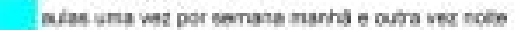

Os minerte ndear os des da serane por ex.

$2-x \lim \sin 2^{*} \sin$

3. avion as ? Fetas

24 aida is 20 a 20 horis

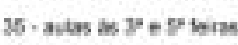

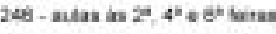

206 - mise de $z^{*}, 30^{*}$ wiras 


\section{Anexo 7}

Área de Conhecimento - CAPES/CNPq 


\section{Áreas de Conhecimento - CAPES/CNPq}

\begin{tabular}{|c|c|}
\hline Grande Área & Área \\
\hline \multirow[t]{8}{*}{ Ciências Exatas e da Terra } & Matemática \\
\hline & Probabilidade e Estatística \\
\hline & Ciência da Computação \\
\hline & Astronomia \\
\hline & Física \\
\hline & Química \\
\hline & Geociências \\
\hline & Oceanografia \\
\hline \multirow[t]{13}{*}{ Ciências Biológicas } & Biologia Geral \\
\hline & Genética \\
\hline & Botânica \\
\hline & Zoologia \\
\hline & Ecologia \\
\hline & Morfologia \\
\hline & Fisiologia \\
\hline & Bioquímica \\
\hline & Biofísica \\
\hline & Farmacologia \\
\hline & Imunologia \\
\hline & Microbiologia \\
\hline & Parasitologia \\
\hline \multirow[t]{8}{*}{ Engenharias } & Engenharia Civil \\
\hline & Engenharia de Minas \\
\hline & Eng de Materiais e Metalúrgica \\
\hline & Engenharia Elétrica \\
\hline & Engenharia Mecânica \\
\hline & Engenharia Química \\
\hline & Engenharia Sanitária \\
\hline & Engenharia de Produção \\
\hline
\end{tabular}

\begin{tabular}{|c|c|}
\hline Grande Área & Área \\
\hline \multirow[t]{7}{*}{ Ciências Agrárias } & Agronomia \\
\hline & Recursos Florestais e Eng Florestal \\
\hline & Engenharia Agrícola \\
\hline & Zootecnia \\
\hline & Medicina Veterinária \\
\hline & Rec Pesqueiros e Eng de Pesca \\
\hline & Ciência e Tecnologia de Alimentos \\
\hline \multirow[t]{8}{*}{ Ciências da Saúde } & Medicina \\
\hline & Odontologia \\
\hline & Farmária \\
\hline & Enfermagem \\
\hline & Nutrição \\
\hline & Saúde Coletiva \\
\hline & Fonoaudiologia \\
\hline & Educação Física \\
\hline \multirow[t]{9}{*}{ Ciências Sociais Aplicadas } & Direito \\
\hline & Administração \\
\hline & Economia \\
\hline & Arquitetura e Urbanismo \\
\hline & Planejamento Urbano e Regional \\
\hline & Demografia \\
\hline & Ciência da Informação \\
\hline & Comunicação \\
\hline & Serviço Social \\
\hline \multirow[t]{5}{*}{ Ciências Humanas } & Filosofia \\
\hline & Sociologia \\
\hline & Antropologia \\
\hline & História \\
\hline & Geografia \\
\hline
\end{tabular}


Engenharia Nuclear

Engenharia de Transportes

Engenharia Naval e Oceânica

Engenharia Aeroespacial

Engenharia Biomédica

Outros

\begin{tabular}{|l|l|} 
& Psicologia \\
\hline & Educação Física \\
\hline & Ciência Política \\
\hline & Teologia \\
\hline Linguística, Letras e Artes & Linguística \\
\hline & Letras \\
\hline & Artes \\
\hline
\end{tabular}

Fonte: http://www.capes.gov.br - obtido em março/98 
Anexo 8

Pós-Graduação Stricto Sensu FSP/USP

Membros das comissões julgadoras de exames de qualificação e defesas segundo escola de origem, 1990 a 1996 
Tabela Anexo 8 - Pós-Graduação Stricto Sensu FSP/USP

Membros das Comissões Julgadoras de Exames de qualificação e defesas segundo escola de origem, 1990 a 1996 *

\begin{tabular}{|c|c|c|c|c|c|c|c|c|c|c|c|c|c|c|}
\hline \multirow[b]{2}{*}{ Escola } & \multicolumn{2}{|c|}{ SSP } & \multicolumn{2}{|c|}{$\mathbf{A H}$} & \multicolumn{2}{|c|}{ SA } & \multicolumn{2}{|c|}{ NUT } & \multicolumn{2}{|c|}{ SMI } & \multicolumn{2}{|c|}{ EPI } & \multicolumn{2}{|c|}{ Total } \\
\hline & $\begin{array}{c}\mathrm{n}^{\circ} \\
901\end{array}$ & $\begin{array}{c}\% \\
100,00\end{array}$ & $\begin{array}{l}n^{\circ} \\
82 \\
\end{array}$ & $\begin{array}{c}\% \\
100,00\end{array}$ & $\begin{array}{c}n^{\circ} \\
406\end{array}$ & $\begin{array}{c}\% \\
100,00\end{array}$ & $\begin{array}{c}n^{\circ} \\
298 \\
\end{array}$ & $\begin{array}{c}\% \\
100,00\end{array}$ & $\begin{array}{c}n^{\circ} \\
342 \\
\end{array}$ & $\begin{array}{c}\% \\
100,00\end{array}$ & $\begin{array}{c}n^{\circ} \\
852 \\
\end{array}$ & $\begin{array}{c}\% \\
100,00\end{array}$ & $\begin{array}{c}n^{\circ} \\
2.881\end{array}$ & $\begin{array}{c}\% \\
100,00\end{array}$ \\
\hline FSP/USP & 503 & 55,83 & 43 & 52,44 & 219 & 53,94 & 184 & 61,74 & 223 & 65,20 & 437 & 51,29 & 1.609 & 55,85 \\
\hline Outras Escolas & 141 & 15,64 & 5 & 6,09 & 39 & 9,60 & 24 & 8,05 & 68 & 19,08 & 92 & 10,79 & 343 & 11,90 \\
\hline FM/USP & 46 & 5,11 & 5 & 6,10 & 14 & 3,45 & 12 & 4,03 & 11 & 3,22 & 97 & 11,38 & 185 & 6,42 \\
\hline Especialista não docente & 34 & 3,77 & 8 & 9,76 & 20 & 4,93 & 15 & 5,03 & 8 & 2,34 & 37 & 4,34 & 122 & 4,23 \\
\hline Med/UNIFESP & 12 & 1,33 & 2 & 2,44 & - & - & 22 & 7,38 & 11 & 3,22 & 40 & 4,69 & 87 & 3,17 \\
\hline FCM/Santa Casa & 28 & 3,11 & 2 & 2,44 & 1 & 0,25 & 2 & 0,67 & 3 & 0,88 & 29 & 3,40 & 65 & 2,26 \\
\hline s/inf & 17 & 1,89 & - & - & 9 & 2,22 & 4 & 1,34 & 1 & 0,29 & 23 & 2,70 & 54 & 1,87 \\
\hline FCM/UNICAMP & 9 & 1,00 & 5 & 6,10 & 8 & 1,97 & 6 & 2,01 & 8 & 2,34 & 16 & 1,88 & 52 & 1,80 \\
\hline EE/USP & 21 & 2,33 & 2 & 2,44 & 2 & 0,49 & 4 & 1,34 & 8 & 2,34 & 8 & 0,94 & 45 & 1,56 \\
\hline EP/USP & - & - & - & - & 44 & 10,84 & - & - & - & - & - & - & 44 & 1,53 \\
\hline FMVZ/USP & 34 & 3,77 & - & - & 1 & 0,25 & 3 & 1,01 & - & - & 5 & 0,59 & 43 & 1,49 \\
\hline ICB/USP & 16 & 1,78 & - & - & 8 & 1,97 & 5 & 1,68 & - & - & 14 & 1,64 & 43 & 1,49 \\
\hline FCF/USP & 7 & 0,78 & 4 & 4,88 & 13 & 3,20 & 13 & 4,36 & - & - & 2 & 0,23 & 39 & 1,35 \\
\hline FMRP/USP & 1 & 0,11 & 2 & 2,44 & 2 & 0,49 & 4 & 1,34 & 4 & 1,17 & 20 & 2,35 & 33 & 1,15 \\
\hline Enf/UNIFESP & 8 & 0,89 & - & - & 1 & 0,25 & - & - & 8 & 2,34 & 4 & 0,47 & 21 & 0,73 \\
\hline ENSP & 1 & 0,11 & - & - & 1 & 0,25 & - & - & 2 & 0,58 & 16 & 1,88 & 20 & 0,69 \\
\hline Psico/PUC & 7 & 0,78 & - & - & - & - & - & - & 12 & 3,51 & - & - & 19 & 0,66 \\
\hline FE/USP & 16 & 1,78 & - & - & - & - & - & - & 1 & 0,29 & 1 & 0,12 & 18 & 0,62 \\
\hline IB/USP & - & - & - & - & 7 & 1,72 & - & - & - & - & 10 & 1,17 & 17 & 0,59 \\
\hline EESC/USP & - & - & - & - & 15 & 3,69 & - & - & - & - & - & - & 15 & 0,52 \\
\hline FAU/USP & - & - & 4 & 4,88 & 2 & 0,49 & - & - & - & - & 1 & 0,12 & 7 & 0,24 \\
\hline
\end{tabular}

*Não inclui os exames de qualificação de 1990 a 1993

Não inclui os orientadores 
Pós graduação Stricto Sensu" FSP/USP

Membros das comissőes julgadoras de exames de qualificaçăo e defesas segundo escola de origem, 1990 a $1996^{*}$.

\begin{tabular}{|c|c|c|c|c|c|c|c|c|c|c|}
\hline Instituiçăo & 1990 & 1991 & 1992 & 1993 & 1994 & 1995 & 1996 & Total & $\%$ & $\%$ Parc \\
\hline TOTAL & 149 & 182 & 186 & 148 & 600 & 621 & 730 & 2616 & $100,00 \%$ & $100,00 \%$ \\
\hline C de Ciênc Hum e Pós-Grad/Univ Braz Cubas & & & & & & & 1 & 1 & $0,04 \%$ & $0,04 \%$ \\
\hline CCSIUFRJ & & & & & & & 2 & 2 & $0,08 \%$ & $0,08 \%$ \\
\hline Dep Adm Escolar e Economia da Educ/FE/USP & & & 1 & & 3 & 3 & 2 & 9 & $0,34 \%$ & $0,34 \%$ \\
\hline Dep Adm/FEAUSPP & & 1 & & & 2 & & & 3 & $0,11 \%$ & $0,11 \%$ \\
\hline Dep Alimentos e Nutriçäo Exp/FCF/USP & & & & & 5 & 1 & 6 & 12 & $0,46 \%$ & $0,46 \%$ \\
\hline Dep Anál Clinicas e Toxicologicas/FCF/USP & 2 & & 3 & 5 & 3 & 1 & 8 & 22 & $0,84 \%$ & $0,84 \%$ \\
\hline Dep Anál Clinicas,Toxicológicas e Bromatológ/FCFRP/USP & & & 1 & & & & 1 & 2 & $0,08 \%$ & $0,08 \%$ \\
\hline Dep Anál Clinicas/CCS/UFSC & & & & & & & 1 & 1 & $0,04 \%$ & $0,04 \%$ \\
\hline Dep Anal Clinicas/FCF/UNESP & & & 1 & & & & & 1 & $0,04 \%$ & $0,04 \%$ \\
\hline Dep Anál Clinicas/FCM/Alfenas & & & & & 1 & & & 1 & $0,04 \%$ & $0,04 \%$ \\
\hline Dep Anatomia Patologica/FM/UFBA & 1 & & & & & & & 1 & $0,04 \%$ & $0,04 \%$ \\
\hline Dep Antropologia/FFLCH/USP & & & & & 1 & 1 & 1 & 3 & $0,11 \%$ & $0,11 \%$ \\
\hline Dep Antropologia/IFC/UNICAMP & & & & & & & 1 & 1 & $0,04 \%$ & $0,04 \%$ \\
\hline Dep Biblioteconomia e Documentaçäo/ECAUUSP & & & & & 2 & & 5 & 7 & $0,27 \%$ & $0,27 \%$ \\
\hline Dep Bio-Estatistica/IB/UNESP & & & & & & & 1 & 1 & $0,04 \%$ & $0,04 \%$ \\
\hline Dep Biofisica/IB/UNESP & & 1 & & & & & & 1 & $0,04 \%$ & $0,04 \%$ \\
\hline Dep Bioquimica/lQ/USP & & 1 & & & & & & 1 & $0,04 \%$ & $0,04 \%$ \\
\hline Dep Botânica do Museu Nacional/UFRJ & & & & & & & 1 & 1 & $0,04 \%$ & $0,04 \%$ \\
\hline Dep C Biológicas/ENSP & & & & & 1 & & & 1 & $0,04 \%$ & $0,04 \%$ \\
\hline Dep C Sociais aplicada a Educ/FE/UNICAMP & & & & & 2 & & & 2 & $0,08 \%$ & $0,08 \%$ \\
\hline Dep C Sociais/ENSP & & & & & 1 & & & 1 & $0,04 \%$ & $0,04 \%$ \\
\hline Dep Cardiopatia e Gravidez/FCM/Santa Casa & & & & & 1 & & & 1 & $0,04 \%$ & $0,04 \%$ \\
\hline Dep Cärdio-Pneumologia/FM/USP & 3 & & & 1 & 4 & 3 & 2 & 13 & $0,50 \%$ & $0,50 \%$ \\
\hline Dep Centro de Informática em Saūde/UNIFESP & 1 & & & & & & & 1 & $0,04 \%$ & $0,04 \%$ \\
\hline Dep Ciências Biológicas/FCF/UNESP & & & 1 & & & & 1 & 2 & $0,08 \%$ & $0,08 \%$ \\
\hline Dep Ciências da Computação/IME/USP & & & & & 1 & & & 1 & $0,04 \%$ & $0,04 \%$ \\
\hline Dep Ciências Econômicas/UFMG & 1 & & & & & & & 1 & $0,04 \%$ & $0,04 \%$ \\
\hline Dep Ciências Sociais/ENSP & & & & & & 1 & 2 & 3 & $0,11 \%$ & $0,11 \%$ \\
\hline Dep Ciências Sociais/UEM & & & & & & & 1 & 1 & $0,04 \%$ & $0,04 \%$ \\
\hline Dep Cirurgia/FM/UNESP & & & & & 1 & & & 1 & $0,04 \%$ & $0,04 \%$ \\
\hline Dep Cirurgia/FM/USP & 2 & & & & 1 & 1 & & 4 & $0,15 \%$ & $0,15 \%$ \\
\hline Dep Clinica Méd/FCM/UNICAMP & & & 1 & & 1 & 2 & & 4 & $0,15 \%$ & $0,15 \%$ \\
\hline Dep Clinica Méd/FM/UFMG & & & & 1 & & & & 1 & $0,04 \%$ & $0,04 \%$ \\
\hline
\end{tabular}


Pós graduaçăo Stricto Sensu" FSP/USP

Membros das comissōes julgadoras de exames de qualificaçăo e defesas segundo escola de origem, 1990 a $1996^{*}$.

\begin{tabular}{|c|c|c|c|c|c|c|c|c|c|c|}
\hline Instituição & 1990 & 1991 & 1992 & 1993 & 1994 & 1995 & 1996 & Total & $\%$ & $\%$ Parc \\
\hline Dep Clinica Med/FM/USP & 3 & 1 & 3 & 1 & & & 3 & 11 & $0.42 \%$ & $0,42 \%$ \\
\hline Dep Clinica Méd/FMRP/USP & 1 & & & & 2 & & 4 & 7 & $0.27 \%$ & $0,27 \%$ \\
\hline Dep Clinica Méd/FMVZ/USP & & & & & & 2 & 5 & 7 & $0.27 \%$ & $0,27 \%$ \\
\hline Dep Clinica Méd/UFMG & & & & & 1 & & & 1 & $0,04 \%$ & $0,04 \%$ \\
\hline Dep Clinica Méd/Univ Fed Uberlândia & & & & & & 1 & 1 & 2 & $0,08 \%$ & $0,08 \%$ \\
\hline Dep Clinica/FCM/UNICAMP & & & & & & 1 & & 1 & $0,04 \%$ & $0,04 \%$ \\
\hline Dep Clinica/FCM/Univ São Francisco & & & & & & & 1 & 1 & $0.04 \%$ & $0,04 \%$ \\
\hline Dep Comunicaçöes e Artes/ECAUSP & & & & & 1 & & & 1 & $0,04 \%$ & $0,04 \%$ \\
\hline Dep Dç Infecciosas e Parasitárias/FM/USP & & & & & 4 & 4 & 5 & 13 & $0,50 \%$ & $0,50 \%$ \\
\hline Dep Dç Infecciosas e Parasitárias/Inst de Med Tropica//FM/USP & & & & & & 1 & & 1 & $0,04 \%$ & $0,04 \%$ \\
\hline Dep Dç Infecciosas e Parasitárias/UNIFESP & & & & & 5 & 3 & 4 & 12 & $0.46 \%$ & $0,46 \%$ \\
\hline Dep Dermatologia/FMUNESP & & & & & & & 1 & 1 & $0,04 \%$ & $0,04 \%$ \\
\hline Dep Dermatologia/FM/USP & & & & 1 & 1 & & & 2 & $0,08 \%$ & $0,08 \%$ \\
\hline Dep Dermatologia/UNIFESP & & & & & 1 & & & 1 & $0.04 \%$ & $0,04 \%$ \\
\hline Dep Direito Civil/FD/USP & & & & & 1 & & & 1 & $0,04 \%$ & $0,04 \%$ \\
\hline Dep Direito do Estado/FD/USP & & & & & 1 & & & 1 & $0,04 \%$ & $0,04 \%$ \\
\hline Dep Direito Penal/FD/USP & & & & & 1 & & & 1 & $0.04 \%$ & $0,04 \%$ \\
\hline Dep Ecologia Geral//B/USP & & & & & 3 & 1 & & 4 & $0.15 \%$ & $0,15 \%$ \\
\hline Dep Econ Doméstica/ESALQVUSP & & 1 & & & & & & 1 & $0.04 \%$ & $0,04 \%$ \\
\hline Dep Economia e Sociologia Rural/ESALQ/USP & & & 1 & & & & & 1 & $0,04 \%$ & $0,04 \%$ \\
\hline Dep Economia/FEA/PUC & & & & 1 & & & & 1 & $0,04 \%$ & $0,04 \%$ \\
\hline Dep Economia/FEA/USP & & & 1 & & & 1 & & 2 & $0,08 \%$ & $0,08 \%$ \\
\hline Dep EducliB/UNESP & & & & 1 & & 1 & & 2 & $0,08 \%$ & $0,08 \%$ \\
\hline Dep Endemias/ENSP & & & & & 1 & & 1 & 2 & $0.08 \%$ & $0,08 \%$ \\
\hline Dep Endocrinologia/FM/USP & & & & & & & 1 & 1 & $0,04 \%$ & $0,04 \%$ \\
\hline Dep Enf Geral e Especializada/EERP/USP & & & & & & 4 & & 4 & $0.15 \%$ & $0,15 \%$ \\
\hline Dep Enf Mat-Infantil e Psiquiátrica/EE/USP & & & & & & & 3 & 3 & $0,11 \%$ & $0,11 \%$ \\
\hline Dep Enf Mat-Infantil e S Pública/EERP/USP & 1 & & & 2 & 3 & 4 & 5 & 15 & $0,57 \%$ & $0,57 \%$ \\
\hline Dep Enf Méd-Ciñ́rgica e Adm em Enf/UFBA & & & & & & & 1 & 1 & $0,04 \%$ & $0,04 \%$ \\
\hline Dep Enf Méd Cirúrgica/EE/USP & 5 & & 1 & & 2 & 3 & 1 & 12 & $0,46 \%$ & $0,46 \%$ \\
\hline Dep Enf S Coletiva/EE/USP & 2 & 3 & 3 & 1 & 9 & 2 & 4 & 24 & $0,92 \%$ & $0,92 \%$ \\
\hline Dep EnUFCM/UNICAMP & 3 & & & & 1 & & 2 & 6 & $0.23 \%$ & $0,23 \%$ \\
\hline Dep EntJUFSCAR & & & & & & & 1 & 1 & $0,04 \%$ & $0,04 \%$ \\
\hline Dep EnfIUNIFESP & 4 & 3 & 2 & 2 & 2 & 5 & 2 & 20 & $0,76 \%$ & $0.77 \%$ \\
\hline
\end{tabular}


Pós graduação Stricto Sensu" FSP/USP

Membros das comissōes julgadoras de exames de qualificação e defesas segundo escola de origem, 1990 a $1996^{\star}$.

\begin{tabular}{|c|c|c|c|c|c|c|c|c|c|c|}
\hline Instituiçāo & 1990 & 1991 & 1992 & 1993 & 1994 & 1995 & 1996 & Total & $\%$ & $\%$ Parc \\
\hline Dep Eng de Minas/EP/USP & & & & & & & 1 & 1 & $0,04 \%$ & $0,04 \%$ \\
\hline Dep Eng de ProduçãolEP/USP & & & & & 1 & 1 & 1 & 3 & $0,11 \%$ & $0,11 \%$ \\
\hline Dep Eng Hidráulica e Sanitária/EP/USP & 2 & 3 & 9 & 7 & 3 & 7 & 5 & 36 & $1,38 \%$ & $1,38 \%$ \\
\hline Dep Entomologia/ENSP & & & & & 1 & 1 & 1 & 3 & $0.11 \%$ & $0,11 \%$ \\
\hline Dep Epidemiologia/ENSP & 1 & & 1 & 1 & 1 & & 2 & 6 & $0.23 \%$ & $0,23 \%$ \\
\hline Dep Epidemiologia/Inst Med SocialUERJ & & & & & & 2 & 1 & 3 & $0,11 \%$ & $0,11 \%$ \\
\hline Dep Esportes/EEF/USP & & & & & & & 1 & 1 & $0,04 \%$ & $0,04 \%$ \\
\hline Dep Estatistica/Centro Ciênc Exatas e Tecno/UFSC & & & & & & & 1 & 1 & $0,04 \%$ & $0,04 \%$ \\
\hline Dep Estatistica/IME/USP & & & 2 & & 2 & 2 & 3 & 9 & $0,34 \%$ & $0,34 \%$ \\
\hline Dep Estatística/UFSCAR & & & & & 1 & & 4 & 5 & $0,19 \%$ & $0,19 \%$ \\
\hline Dep Estomatologia/FO/UFSC & & & & & & & 1 & 1 & $0,04 \%$ & $0,04 \%$ \\
\hline Dep Estomatologia/FO/USP & 1 & & & 1 & & & & 2 & $0.08 \%$ & $0,08 \%$ \\
\hline Dep Farmacotécnica/FCF/USP & & & & & & & 2 & 2 & $0,08 \%$ & $0,08 \%$ \\
\hline Dep Filosofia da Educ e Ciência da Educ/FE/USP & 1 & & & & 1 & 1 & 1 & 4 & $0,15 \%$ & $0,15 \%$ \\
\hline Dep Filosofia do Direito e Teoria Geral do D/FD/USP & & & & & & 1 & & 1 & $0,04 \%$ & $0,04 \%$ \\
\hline Dep Fisio e Biofisica/lCB/USP & & 1 & & & 1 & & & 2 & $0,08 \%$ & $0,08 \%$ \\
\hline Dep Fisiologia/FMRP/USP & & & & & & 1 & & 1 & $0.04 \%$ & $0,04 \%$ \\
\hline Dep Fisioterapia e Terapia Ocupacional/UFSCAR & & & & & 1 & 2 & 1 & 4 & $0,15 \%$ & $0,15 \%$ \\
\hline Dep Fund da Educ e Orientaçăo Educacional do Centro Pedagóg/L & & & & 1 & & & & 1 & $0,04 \%$ & $0,04 \%$ \\
\hline Dep Fundamentos Sociais e Juridicos da Adm/FGV & & & & & & 1 & & 1 & $0.04 \%$ & $0,04 \%$ \\
\hline Dep Geociências/UNICAMP & & & & & 1 & & & 1 & $0,04 \%$ & $0,04 \%$ \\
\hline Dep Geografia/FFLCH/USP & & & & & 1 & & 1 & 2 & $0,08 \%$ & $0,08 \%$ \\
\hline Dep Geologia Econ e Geofisica Aplicada/IG/USP & & & & & 1 & 1 & & 2 & $0,08 \%$ & $0,08 \%$ \\
\hline Dep Geoquimica/UFF & & & & & & 1 & & 1 & $0,04 \%$ & $0,04 \%$ \\
\hline Dep Geriatria/UNIFESP & & & & & & 1 & & 1 & $0,04 \%$ & $0,04 \%$ \\
\hline Dep Ginecologia e Obstetricia/FM/Mogi das Cruzes & & & & & & 1 & & 1 & $0,04 \%$ & $0,04 \%$ \\
\hline Dep Ginecologia e Obstetricia/FM/USP & & & & & 1 & & 2 & 3 & $0.11 \%$ & $0,11 \%$ \\
\hline Dep Hidráulica e Saneamento/EESCIUSP & & 1 & 1 & 2 & 4 & 1 & 3 & 12 & $0.46 \%$ & $0,46 \%$ \\
\hline Dep Higiene Vet e S Pública/FMVZUUNESP & & & 1 & & 1 & 1 & & 3 & $0,11 \%$ & $0,11 \%$ \\
\hline Dep História da Arquit e Estética de Proj/FAU/USP & & & & 1 & 1 & & 1 & 3 & $0.11 \%$ & $0,11 \%$ \\
\hline Dep Imunologia/lCB/USP & & 1 & & & & 1 & & 2 & $0.08 \%$ & $0,08 \%$ \\
\hline Dep Inform para a SIENSP & & & & & & & 1 & 1 & $0.04 \%$ & $0,04 \%$ \\
\hline Dep Linguistica/IEL/UNICAMP & 1 & & & & & & & 1 & $0.04 \%$ & $0,04 \%$ \\
\hline Dep Materno Inf e Saude Comunit/CCSIUEL & & & & & & 1 & & 1 & $0,04 \%$ & $0,04 \%$ \\
\hline
\end{tabular}

- Nho inclui os exames de qualificaçæo de 1990 a 1993

Fonte: Seçdo de Pós-Graduaçāo/FSPIUSP.

Nâo inclui os arientadores. 
Pós graduaçāo Stricto Sensu" FSP/USP

Membros das comissōes julgadoras de exames de qualificação e defesas segundo escola de origem, 1990 a $1996^{\star}$.

\begin{tabular}{|c|c|c|c|c|c|c|c|c|c|c|}
\hline Instituiçăo & 1990 & 1991 & 1992 & 1993 & 1994 & 1995 & 1996 & Total & $\%$ & $\%$ Parc \\
\hline Dep Med Forense/FD/USP & & & & 1 & 1 & & & 2 & $0,08 \%$ & $0,08 \%$ \\
\hline Dep Med Interna/FM/UFRS & & 1 & & & & & & 1 & $0,04 \%$ & $0,04 \%$ \\
\hline Dep Med Prev e Social/FCM/UNICAMP & 2 & 3 & 1 & & 8 & 11 & 6 & 31 & $1,19 \%$ & $1,19 \%$ \\
\hline Dep Med Prev e Social/FM/UFMG & & & 2 & & & & & 2 & $0,08 \%$ & $0,08 \%$ \\
\hline Dep Med Prev/FM/UFRJ & & & & & & 1 & & 1 & $0,04 \%$ & $0,04 \%$ \\
\hline Dep Med Prev/FM/UFRS & & & & & & & 1 & 1 & $0,04 \%$ & $0,04 \%$ \\
\hline Dep Med Prev/FM/USP & 2 & 1 & 3 & & 14 & 22 & 20 & 62 & $2,37 \%$ & $2,37 \%$ \\
\hline Dep Med Prev/UNIFESP & 1 & 1 & 2 & 2 & 7 & 7 & 11 & 31 & $1,19 \%$ & $1,19 \%$ \\
\hline Dep Med Social/FCM/PUCCAMP & & 1 & 1 & & & 1 & & 3 & $0,11 \%$ & $0,11 \%$ \\
\hline Dep Med Social/FCM/Santa Casa & 4 & 1 & 7 & 2 & 16 & 12 & 12 & 54 & $2,06 \%$ & $2,07 \%$ \\
\hline Dep Med Social/FCM/Santa Casa & & 1 & & & & & & 1 & $0,04 \%$ & $0,04 \%$ \\
\hline Dep Med Social/FM/UFBA & & & & & 1 & & & 1 & $0,04 \%$ & $0,04 \%$ \\
\hline Dep Med Social/FM/UFRS & & & & 1 & & & & 1 & $0,04 \%$ & $0,04 \%$ \\
\hline Dep Med Social/FMRP/USP & 2 & 3 & & & 8 & 5 & 3 & 21 & $0.80 \%$ & $0,80 \%$ \\
\hline Dep Med Social/UFPE & & & & 2 & & 1 & & 3 & $0,11 \%$ & $0,11 \%$ \\
\hline Dep Med Social/UFRJ & & 1 & & & & & & 1 & $0,04 \%$ & $0,04 \%$ \\
\hline Dep Med Vet Prev e S Animal/FMVZ/USP & & 2 & 1 & & 8 & B & 6 & 25 & $0,96 \%$ & $0,96 \%$ \\
\hline Dep Med Vet Prev/FCAV/UNESP & & & 1 & & 1 & 1 & 2 & 5 & $0,19 \%$ & $0,19 \%$ \\
\hline Dep Med/UNIFESP & 1 & & & & & & & 1 & $0,04 \%$ & $0,04 \%$ \\
\hline Dep Metodologia do Ensino e Educ Comparada/FE/USP & & 1 & & 1 & & 1 & 1 & 4 & $0,15 \%$ & $0,15 \%$ \\
\hline Dep Micologia Clinica/FCF/UNESP & & & & & 1 & & & 1 & $0,04 \%$ & $0,04 \%$ \\
\hline Dep Micro e Imuno/IB/UNICAMP & & & & & 1 & & & 1 & $0,04 \%$ & $0,04 \%$ \\
\hline Dep Microbiologia Oral/ICB/USP & & & & & & & 1 & 1 & $0,04 \%$ & $0,04 \%$ \\
\hline Dep Microbiologia/ICB IUUSP & & & & & & 1 & & 1 & $0.04 \%$ & $0,04 \%$ \\
\hline Dep Microbiologia//CB/USP & 2 & 2 & 1 & & 5 & 10 & 4 & 24 & $0.92 \%$ & $0,92 \%$ \\
\hline Dep Moléstias Infecto-Contagiosa/FCM/Santa Casa & & & & 1 & & & & 1 & $0,04 \%$ & $0,04 \%$ \\
\hline Dep Neurologia e Psiquiatria/FM/UNESP & & & & & & & 2 & 2 & $0,08 \%$ & $0,08 \%$ \\
\hline Dep Neurologia/FCM/UNICAMP & & & & & 1 & 1 & & 2 & $0,08 \%$ & $0,08 \%$ \\
\hline Dep Neurologia/FM/USP & & & & 1 & 1 & 2 & & 4 & $0,15 \%$ & $0,15 \%$ \\
\hline Dep Nutriçāo Social/FN/UFF & & & & & 1 & & 1 & 2 & $0.08 \%$ & $0,08 \%$ \\
\hline Dep Nutrição/UFPE & & & & & & 1 & & 1 & $0,04 \%$ & $0,04 \%$ \\
\hline Dep Obstetricia e Ginecologia/FM/USP & & 1 & 1 & & & & & 2 & $0,08 \%$ & $0,08 \%$ \\
\hline Dep Obstetricia/FCM/Santa Casa & & & & & 1 & & & 1 & $0,04 \%$ & $0,04 \%$ \\
\hline Dep Oceanografia Biológica/IO/USP & & & & 1 & & & & 1 & $0,04 \%$ & $0,04 \%$ \\
\hline
\end{tabular}


Pós graduação Stricto Sensu" FSP/USP

Membros das comissōes julgadoras de exames de qualificaçāo e defesas segundo escola de origem, 1990 a $1996^{*}$.

\begin{tabular}{|c|c|c|c|c|c|c|c|c|c|c|}
\hline Instituiçäo & 1990 & 1991 & 1992 & 1993 & 1994 & 1995 & 1996 & Total & $\%$ & $\%$ Parc \\
\hline Dep Odonto Infantil/FOP/UNICAMP & & & & & & & 1 & 1 & $0,04 \%$ & $0,04 \%$ \\
\hline Dep Odonto Prev e S Pública/FO/UNESP & & & & & 2 & 1 & 1 & 4 & $0,15 \%$ & $0,15 \%$ \\
\hline Dep Odonto Prev e Social/FO/UERJ & & & & & 2 & & & 2 & $0,08 \%$ & $0,08 \%$ \\
\hline Dep Odonto Social/FO/UNESP & & & & 4 & 3 & 3 & 2 & 12 & $0,46 \%$ & $0.46 \%$ \\
\hline Dep Odonto Social/FOB/USP & & 1 & 1 & 1 & 1 & 1 & & 5 & $0,19 \%$ & $0,19 \%$ \\
\hline Dep Odonto Social/FOP/UNICAMP & & 1 & & 1 & & 3 & 1 & 6 & $0,23 \%$ & $0,23 \%$ \\
\hline Dep Odonta/CCS/UFAL & & & 1 & & & & & 1 & $0,04 \%$ & $0,04 \%$ \\
\hline Dep Odonto/FO/UEM & & & & & 1 & 1 & 1 & 3 & $0,11 \%$ & $0,11 \%$ \\
\hline Dep Odontol Social/FO/UNESP & & & & & & 1 & & 1 & $0,04 \%$ & $0,04 \%$ \\
\hline Dep Odontopediatria/FO/UNICAMP & & & & 1 & & & & 1 & $0,04 \%$ & $0,04 \%$ \\
\hline Dep Oftalmo e Otorrino/FCMUUNICAMP & & & & & 1 & & & 1 & $0,04 \%$ & $0,04 \%$ \\
\hline Dep Oftalmo e Otorrino/FM/USP & 1 & & & & & & 1 & 2 & $0,08 \%$ & $0,08 \%$ \\
\hline Dep Orientaçåo Profissional/EE/USP & & & & & & & 1 & 1 & $0,04 \%$ & $0,04 \%$ \\
\hline Dep Ortodontia e Odontopediatria/FO/USP & & 1 & & & 3 & 1 & & 5 & $0,19 \%$ & $0,19 \%$ \\
\hline Dep Ortopedia e Traumatologia/FM/USP & & & & 2 & 1 & & & 3 & $0,11 \%$ & $0,11 \%$ \\
\hline Dep Parasitologia/FCF/UNESP & & & & & & & 1 & 1 & $0,04 \%$ & $0,04 \%$ \\
\hline Dep Parasitologia/IB/UNESP & & & & & 3 & 1 & 3 & 7 & $0,27 \%$ & $0,27 \%$ \\
\hline Dep Parasitologia/IB/UNICAMP & & & 1 & & 1 & 2 & & 4 & $0,15 \%$ & $0,15 \%$ \\
\hline Dep Parasitologia/ICB/USP & & 3. & 1 & & 2 & & 3 & 9 & $0,34 \%$ & $0,34 \%$ \\
\hline Dep Patologia Clinica/UNIFESP & & & & & & & 1 & 1 & $0,04 \%$ & $0,04 \%$ \\
\hline Dep Patologia/FM/USP & 1 & 1 & & & 2 & 8 & 5 & 17 & $0,65 \%$ & $0,65 \%$ \\
\hline Dep Pediatria e Puericultura/FCM/Santa Casa & & & & & 1 & & & 1 & $0,04 \%$ & $0,04 \%$ \\
\hline Dep Pediatria e Puericultura/FM/ABC & & & & & & 1 & & 1 & $0,04 \%$ & $0,04 \%$ \\
\hline Dep Pediatria e Puericultura/FMUFRS & & & & & & & 1 & 1 & $0,04 \%$ & $0,04 \%$ \\
\hline Dep Pediatria/FCM/Santos & & & & & & & 1 & 1 & $0,04 \%$ & $0,04 \%$ \\
\hline Dep Pediatria/FCM/UNICAMP & & & & & 2 & & & 2 & $0,08 \%$ & $0,08 \%$ \\
\hline Dep Pediatria/FM/OSEC & & 1 & & & & & & 1 & $0,04 \%$ & $0,04 \%$ \\
\hline Dep Pediatria/FM/UNESP & & & & & & & 1 & 1 & $0,04 \%$ & $0,04 \%$ \\
\hline Dep Pediatria/FM/USP & 2 & 1 & & 1 & 7 & 6 & 3 & 20 & $0,76 \%$ & $0,77 \%$ \\
\hline Dep Pediatria/FMRP/USP & & & & & & & 1 & 1 & $0,04 \%$ & $0,04 \%$ \\
\hline Dep Pediatria/UNIFESP & 4 & 3 & & & 9 & 2 & 3 & 21 & $0,80 \%$ & $0,80 \%$ \\
\hline Dep Planej Alimentar e Nutriçao/Fac Eng Alimentos/UNICAMP & & & & & & & 2 & 2 & $0,08 \%$ & $0,08 \%$ \\
\hline Dep Politica e História Econômica/Inst Economia/UNICAMP & & & & & 1 & 1 & & 2 & $0,08 \%$ & $0,08 \%$ \\
\hline Dep Principios Ativos, Naturais e Toxicologicos/FCF/UNESP & & & 2 & & & & & 2 & $0,08 \%$ & $0,08 \%$ \\
\hline
\end{tabular}


Pós graduaçāo Stricto Sensu" FSP/USP

Membros das comissōes julgadoras de exames de qualificação e defesas segundo escola de origem, 1990 a $1996^{*}$.

\begin{tabular}{|c|c|c|c|c|c|c|c|c|c|c|}
\hline Instituiça & 1990 & 1991 & 1992 & 1993 & 1994 & 1995 & 1996 & Total & $\%$ & $\%$ Pare \\
\hline Dep Produçào Animal/FMVZUUSP & & & & & & & 1 & 1 & $0,04 \%$ & $0,04 \%$ \\
\hline Dep Psico Clinica/IP/USP & & & & 1 & & & & 1 & $0,04 \%$ & $0,04 \%$ \\
\hline Dep Psico da Aprend, do Desenv e da Personalidade/IP/USP & & 1 & & & & & 1 & 2 & $0,08 \%$ & $0.08 \%$ \\
\hline Dep Psico ExpllP/USP & & & & & 3 & 3 & & 6 & $0,23 \%$ & $0.23 \%$ \\
\hline Dep Psico Social e do Trabalho/IPIUSP & & & & 1 & & & 2 & 3 & $0,11 \%$ & $0.11 \%$ \\
\hline Dep Psico Social/PUC & & & & & & & 1 & 1 & $0,04 \%$ & $0.04 \%$ \\
\hline Dep Psico/UFSCAR & & & & & 1 & 1 & & 2 & $0,08 \%$ & $0,08 \%$ \\
\hline Dep Psiquiatria/FM/USP & & & & & & 2 & 2 & 4 & $0,15 \%$ & $0,15 \%$ \\
\hline Dep Puericultura e Pediatria/FMRP/USP & & & & & 1 & & 1 & 2 & $0,08 \%$ & $0,08 \%$ \\
\hline Dep Rel Públicas, Propaganda e Turismo/ECA/USP & & & 1 & & & & & 1 & $0,04 \%$ & $0.04 \%$ \\
\hline Dep Reumatologia/UNIFESP & & & & & & & 1 & 1 & $0,04 \%$ & $0.04 \%$ \\
\hline Dep S Coletiva/IPTSP/UFGO & & & & & & & 1 & 1 & $0,04 \%$ & $0.04 \%$ \\
\hline Dep S Pública/FM/UNESP & 2 & 1 & 1 & & 2 & 2 & 3 & 11 & $0,42 \%$ & $0.42 \%$ \\
\hline Dep S Pública/UFSC & & & & & & 1 & & 1 & $0,04 \%$ & $0,04 \%$ \\
\hline Dep Sociologia e Antropologia/FFC/UNESP & & & 2 & 1 & & & 1 & 4 & $0,15 \%$ & $0,15 \%$ \\
\hline Dep Sociologia/Fac Ciências e Letras/UNESP & & & 1 & & & & & 1 & $0,04 \%$ & $0,04 \%$ \\
\hline Dep Sociologia/FFLCH/USP & & 2 & & & & 4 & 1 & 7 & $0,27 \%$ & $0.27 \%$ \\
\hline Dep Sociologia/IFCH/UNICAMP & & & 1 & & 2 & 1 & & 4 & $0,15 \%$ & $0,15 \%$ \\
\hline Dep Tecnologia Bioq Farmacêtica/FCF/USP & & 1 & & & & & & 1 & $0,04 \%$ & $0.04 \%$ \\
\hline Dep Tecnologia da Arquitetura/FAU/USP & & & 2 & & 2 & & & 4 & $0,15 \%$ & $0.15 \%$ \\
\hline Dep Tecnologia de Alimentos/Fac Eng Alimentos/UNICAMP & & & & & & 1 & & 1 & $0,04 \%$ & $0,04 \%$ \\
\hline Dep Tocoginecologia/FCM/UNICAMP & & & 1 & & & & & 1 & $0,04 \%$ & $0.04 \%$ \\
\hline Dep Tocoginecologia/UNIFESP & 1 & 3 & & & 2 & 1 & 1 & 8 & $0,31 \%$ & $0,31 \%$ \\
\hline Dep Zoologia/B/UNICAMP & & 1 & & & & & 1 & 2 & $0,08 \%$ & $0.08 \%$ \\
\hline Dep Zoologia/B/USP & 1 & 1 & & & 1 & & 2 & 5 & $0,19 \%$ & $0.19 \%$ \\
\hline Dep Zoologia/UFP & 2 & & & & & & & 2 & $0,08 \%$ & $0.08 \%$ \\
\hline Direito/PUC & & & & & 2 & & & 2 & $0,08 \%$ & $0,08 \%$ \\
\hline ENSP & & & & & & 1 & & 1 & $0,04 \%$ & $0,04 \%$ \\
\hline EP/USP & & & & & & 1 & & 1 & $0,04 \%$ & $0,04 \%$ \\
\hline Esc Eng da Univ Sảo Francisco & & & & & & & 1 & 1 & $0,04 \%$ & $0,04 \%$ \\
\hline Esc Eng Itatiba & & & & & & & 1 & 1 & $0.04 \%$ & $0.04 \%$ \\
\hline Escola Adm Empresas/FGV & & & & & 1 & & & 1 & $0,04 \%$ & $0,04 \%$ \\
\hline Escola de Sociologia e Politica & & & & & 1 & & 2 & 3 & $0,11 \%$ & $0.11 \%$ \\
\hline Especialista näo docente & 6 & 14 & 7 & 6 & 17 & 26 & 36 & 112 & $4,28 \%$ & $4,29 \%$ \\
\hline
\end{tabular}

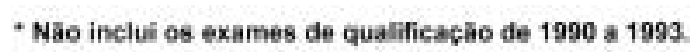

Fonte: Seçăo de Pós-Graduaçào/FSPJUSP.

Nào inclui os orientadores. 
Pós graduação Stricto Sensu" FSP/USP

Membros das comissōes julgadoras de exames de qualificação e defesas segundo escola de origem, 1990 a 1996 *.

\begin{tabular}{|c|c|c|c|c|c|c|c|c|c|c|}
\hline Instituição & 1990 & 1991 & 1992 & 1993 & 1994 & 1995 & 1996 & Total & $\%$ & $\%$ Parc \\
\hline Faculdade de Medicina de Taubaté & & 1 & & & & & & 1 & $0,04 \%$ & $0,04 \%$ \\
\hline FCM/Santa Casa & 1 & & & & 1 & & & 2 & $0,08 \%$ & $0,08 \%$ \\
\hline FMUIFRS & & & 1 & & & & & 1 & $0,04 \%$ & $0,04 \%$ \\
\hline FMU & & & & & & 1 & & 1 & $0,04 \%$ & $0,04 \%$ \\
\hline FO/Barretos/FEB & & & 1 & & & & & 1 & $0,04 \%$ & $0,04 \%$ \\
\hline FOIUEM & & & & & & 1 & & 1 & $0,04 \%$ & $0,04 \%$ \\
\hline FOIUNESP & & & & & 1 & & & 1 & $0.04 \%$ & $0,04 \%$ \\
\hline Fund Oswaldo Cruz/RJ & & & & & & & 1 & 1 & $0,04 \%$ & $0,04 \%$ \\
\hline HEP/FSP/USP & 29 & 35 & 29 & 26 & 103 & 124 & 121 & 467 & $17.85 \%$ & $17,89 \%$ \\
\hline HNT/FSP/USP & 13 & 5 & 4 & 3 & 25 & 24 & 49 & 123 & $4,70 \%$ & $4,71 \%$ \\
\hline HSAIFSP/USP & 7 & 15 & 21 & 21 & 42 & 47 & 47 & 200 & $7,65 \%$ & $7,66 \%$ \\
\hline HSM/FSP/USP & 5 & 19 & 21 & 15 & 54 & $6 B$ & 76 & 258 & $9,86 \%$ & $9,88 \%$ \\
\hline HSP/FSPIUSP & 20 & 29 & 28 & 22 & 104 & 98 & 121 & 422 & $16.13 \%$ & $16,16 \%$ \\
\hline IB/USP & & & & & 1 & 3 & 2 & 6 & $0.23 \%$ & $0,23 \%$ \\
\hline ICBIUSP & & 2 & & & 2 & 3 & 2 & 9 & $0,34 \%$ & $0,34 \%$ \\
\hline IFCH/UNICAMP & & & & & 1 & & & 1 & $0,04 \%$ & $0,04 \%$ \\
\hline Inst Economia/NEP/UNICAMP & & & & & & 2 & 1 & 3 & $0,11 \%$ & $0,11 \%$ \\
\hline Inst Med SocialUERJ & & & & & & 1 & & 1 & $0,04 \%$ & $0,00 \%$ \\
\hline Inst Nutriçăo/UFPE & & & & & 1 & & & 1 & $0,04 \%$ & $0,00 \%$ \\
\hline Inst Quimica/UNESP & & & & & & & 1 & 1 & $0.04 \%$ & $0.00 \%$ \\
\hline IPEN/USP & & & & & & & 1 & 1 & $0,04 \%$ & $0,00 \%$ \\
\hline IQ/USP & & & & & 1 & & & 1 & $0,04 \%$ & $0,00 \%$ \\
\hline PEPG C. Sociais/PUC & & & & & & & 1 & 1 & $0,04 \%$ & $0,04 \%$ \\
\hline PEPG Ciências Sociais/PUC & & & & & & & 1 & 1 & $0,04 \%$ & $0,04 \%$ \\
\hline PEPG Distùrbios da Cominicação/PUC & & & & & & & 1 & 1 & $0,04 \%$ & $0,04 \%$ \\
\hline PEPG Distúrbios da Comunicação/PUC & & & & & 1 & & 3 & 4 & $0,15 \%$ & $0,15 \%$ \\
\hline PEPG Geografia/PUC & 1 & 1 & 2 & & & & & 4 & $0,15 \%$ & $0,15 \%$ \\
\hline PEPG História/PUC & & & & & & 1 & 1 & 2 & $0,08 \%$ & $0,08 \%$ \\
\hline PEPG Psico Clinica/PUC & & & & & & & 1 & 1 & $0,04 \%$ & $0,04 \%$ \\
\hline PEPG Psico Educ/PUC & 1 & & & & 1 & & 2 & 4 & $0,15 \%$ & $0,15 \%$ \\
\hline PEPG Psico Educaçāo/PUC & & & & & & & 1 & 1 & $0,04 \%$ & $0,04 \%$ \\
\hline PEPG Psico Social/PUC & & 1 & & & 3 & 2 & 5 & 11 & $0,42 \%$ & $0,42 \%$ \\
\hline PEPG Serviço Social/PUC & & & & & 1 & 1 & & 2 & $0,08 \%$ & $0,08 \%$ \\
\hline PEPG Supervisão Curricular/PUC & & & & & & & 1 & 1 & $0,04 \%$ & $0,04 \%$ \\
\hline
\end{tabular}




\section{Pós graduação Stricto Sensu" FSP/USP}

Membros das comissōes julgadoras de exames de qualificação e defesas segundo escola de origem, 1990 a $1996^{*}$.

\begin{tabular}{|c|c|c|c|c|c|c|c|c|c|c|}
\hline Instituiçằo & 1990 & 1991 & 1992 & 1993 & 1994 & 1995 & 1996 & Total & $\%$ & $\%$ Parc \\
\hline PEPG/Psico Social/PUC & & & & & 1 & & 1 & 2 & $0,08 \%$ & $0,08 \%$ \\
\hline s/int & 3 & 2 & 3 & 1 & 13 & 11 & 12 & 45 & $1,72 \%$ & $1.72 \%$ \\
\hline UFSC & & & 1 & & & & & 1 & $0,04 \%$ & $0,04 \%$ \\
\hline UNI RIO & & & & & 1 & & & 1 & $0,04 \%$ & $0,04 \%$ \\
\hline UNICAMP & & & & & & & 2 & 2 & $0,08 \%$ & $0.08 \%$ \\
\hline
\end{tabular}


Autorizo, exclusivamente para fins acadêmicos e científicos, a reprodução total ou parcial desta tese por processsos fotocopiadores.

Assinatura:

Data: 02/02/99

Foto da capa: Faculdade de Saúde Pública/USP na década de 40.

Acervo do Centro de Memória Iconográfica da Faculdade de Saúde Pública/USP 